Supporting Information

for

\title{
Palladium-Catalyzed gem-Difluoroallylation Reaction between Aryltributyltin and Bromodifluoromethylated
} Alkenes

Xiao-Qu Chen, ${ }^{\#}$ Heng Lu, ${ }^{\#}$ Chuan-Xin Chen, Ruoqing Zeng, Dong-Yu Wang, Chang-Yun Shi, ${ }^{*}$ and Ao Zhang*

Pharm-X Center, Research Laboratory of Medicinal Chemical Biology \& Frontiers on Drug Discovery (RLMCBFDD), College of Pharmaceutical Sciences, Shanghai Jiao Tong University, 800 Dongchuan Road, Shanghai 200240, China

*E-mail: ao6919zhang@sjtu.edu.cn (A. Z.)

*E-mail: shicy@sjtu.edu.cn (C.-Y. S) 
1. General Methods for Experiments

2. General Procedures for Preparation of Aryltributylstannanes

3. Synthesis and Characterization of Substrates 1n, 1v, 1w, 1y, 2b-2d and $7 f$

4. Synthesis of compound $4 a$ S11

5. Synthesis of compound 5a S12

6. Transformations of $\alpha, \alpha$-Difluoallylation Product 8a .$S 12$

7. References S13

8. Copies of NMR Spectra Data .$S 15$ 


\section{General Methods for Experiments}

Solvents: Acetone and EtOAc were obtained from commercial sources and used without further distillation. 1,4-Dioxane, toluene and THF were distilled from sodium and benzophenone immediately before use.

Catalysts: All the catalysts used in this report were obtained from commercial sources and used without further purification.

Materials: Phenyltributylstannane, Vinyltributylstannane and BDFP were obtained from commercial sources and used without further purification. Aryltributylstannane substrates, ${ }^{1}$ BDFP derivatives, ${ }^{2 a-c}$ and aryltributyltins ${ }^{3 a-c}$ derived from bioactive molecules were prepared by following literature procedures.

\section{General Procedures for Preparation of Aryltributylstannanes}

\section{Method A: From Aryl Bromides/Iodides and $\left({ }^{n} \mathrm{Bu}_{3} \mathrm{Sn}\right)_{2}$}

For 1k-l, 1s: ${ }^{1 a, 1 b}$

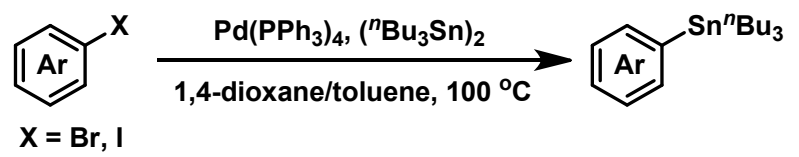

To a solution of aryl bromides or iodides (2.00 mmol, 1.0 equiv.) in 1,4-dioxane/toluene $(5 \mathrm{~mL})$ under argon at $23{ }^{\circ} \mathrm{C}$, was added tetrakis(triphenylphosphine)palladium (0.10 mmol, $5.0 \mathrm{~mol} \%)$, and bis(tri- $n$-butyltin) (1.23 mL, $2.4 \mathrm{mmol}, 1.2$ equiv.). The mixture was stirred for $12-24 \mathrm{~h}$ at $100{ }^{\circ} \mathrm{C}$ (oil bath). After completion of the reaction as indicated by TLC, the reaction mixture was cooled to $23{ }^{\circ} \mathrm{C}$ and concentrated in vacuo. The residue was purified by chromatography on silica gel to give the corresponding products $\mathbf{1 k - l , 1 s .}$

For $1 \mathrm{~h}-\mathbf{j}, 1 \mathrm{~m} \mathbf{:}^{1 \mathrm{c}}$

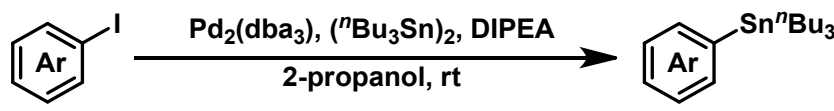

To a solution of aryl iodides $(2.0$ mmol, 1.0 equiv. $)$ and tris(dibenzylideneacetone)dipalladium(0) (0.05 mmol, $2.5 \mathrm{~mol} \%)$ under argon, was 
added $20 \mathrm{~mL}$ 2-propanol. $N, N$-Diisopropylethylamine (5.0 mmol, 2.5 equiv.) was then added, followed by bis(tributyltin) $(2.2 \mathrm{mmol}, 1.1$ equiv.). The mixture was stirred overnight at rt. After completion of the reaction as indicated by TLC, the mixture was concentrated in vacuo. The residue was purified by chromatography on silica gel to give the corresponding products $\mathbf{1 h}-\mathbf{j}, \mathbf{1} \mathbf{m}$.

Method B: From Aryl Bromides/Iodines and ${ }^{n} \mathrm{Bu}_{3} \mathrm{SnCl}$ (for 1a-g, 1o-p, 1q-r, 1t,

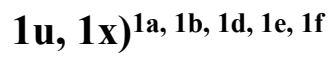

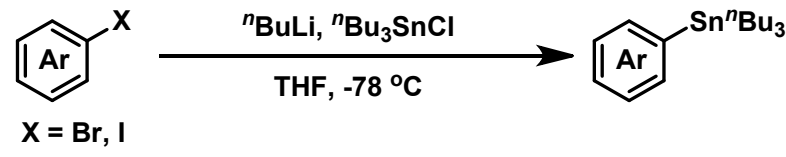

To a solution of aryl bromides/iodides ( $2.0 \mathrm{mmol}, 1.0$ equiv.) in THF ( $5 \mathrm{~mL})$ in flask was added n-butyllithium (2.2 mol, 1.6 $\mathrm{M}$ in THF) at $-78{ }^{\circ} \mathrm{C}$ under argon. The mixture was stirred at $-78{ }^{\circ} \mathrm{C}$ for $0.5-1 \mathrm{~h}$ before ${ }^{n} \mathrm{Bu} 3 \mathrm{SnCl}(2.2 \mathrm{mmol}, 1.1$ equiv. $)$ was added. The mixture was allowed to stir for another $1-3 \mathrm{~h}$ at $-78^{\circ} \mathrm{C}$ before quenching with saturated aqueous $\mathrm{NH}_{4} \mathrm{Cl}(10 \mathrm{~mL})$. The reaction mixture was then extracted with EA $(3 \times 10 \mathrm{~mL})$. The combined organic phase was washed with brine $(30 \mathrm{~mL})$, dried with anhydrous $\mathrm{Na}_{2} \mathrm{SO}_{4}$ and concentrated in vacuo. The residue was purified by chromatography on silica gel to give the final products. (Note: for $\mathbf{1 q} / \mathbf{1} \mathbf{r}$, the reaction temperature is $0{ }^{\circ} \mathrm{C}$ )

3. Synthesis and Characterization of Substrates 1n, 1v, 1w, 1y, 2b-2d and $7 f$

\section{For compound 1n:}

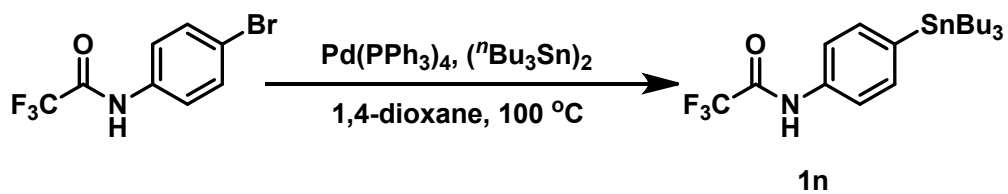

To a solution of N-(4-bromophenyl)-2,2,2-trifluoroacetamide (534 mg, $2.0 \mathrm{mmol}$, 1.0 equiv.) in 1,4-dioxane (5 mL) was added tetrakis(triphenylphosphine)palladium (115 mg, $0.10 \mathrm{mmol}, 5.0 \mathrm{~mol} \%)$ and bis(tri- $n$-butyltin) (1.23 mL, $2.4 \mathrm{mmol}, 1.2$ equiv.) at room temperature. After stirring for $12 \mathrm{~h}$ at $100{ }^{\circ} \mathrm{C}$ (oil bath), the reaction mixture was cooled to $23{ }^{\circ} \mathrm{C}$ and concentrated in vacuo. The residue was purified by chromatography (eluent: petroleum ether/EtOAc $=60: 1)$ to afford the title compound 
1n as a yellow oil in 33\% yield (316 mg). ${ }^{1} \mathrm{H}$ NMR (400 MHz, $\left.\mathrm{CDCl}_{3}\right): \delta 7.99(\mathrm{~s}, 1 \mathrm{H})$, $7.53(\mathrm{~d}, J=6.6 \mathrm{~Hz}, 2 \mathrm{H}), 7.49(\mathrm{~d}, J=8.4 \mathrm{~Hz}, 2 \mathrm{H}), 1.59-1.49(\mathrm{~m}, 6 \mathrm{H}), 1.38-1.29(\mathrm{~m}$, $6 \mathrm{H}), 1.11-1.02(\mathrm{~m}, 6 \mathrm{H}), 0.90(\mathrm{t}, J=7.3 \mathrm{~Hz}, 9 \mathrm{H}) .{ }^{13} \mathrm{C}\left\{{ }^{1} \mathrm{H}\right\} \mathrm{NMR}\left(101 \mathrm{MHz}, \mathrm{CDCl}_{3}\right)$ : $\delta 155.9\left(\mathrm{C}-\mathrm{F}, \mathrm{q},{ }^{2} J_{\mathrm{C}-F}=37.37 \mathrm{~Hz}\right), 140.7,137.5,135.1,120.0,115.9\left(\mathrm{C}-\mathrm{F}, \mathrm{q},{ }^{1} J_{C-F}=\right.$ $289.9 \mathrm{~Hz}), 29.2,27.5,13.8,9.8 .{ }^{19} \mathrm{~F}$ NMR $\left(377 \mathrm{MHz}, \mathrm{CDCl}_{3}\right): \delta-75.73(\mathrm{~s}, 3 \mathrm{~F})$. HRMS (ESI-TOF) m/z: [M-H]- calculated for $\mathrm{C}_{20} \mathrm{H}_{31} \mathrm{~F}_{3} \mathrm{NOSn}^{-}$: 478.1385; found: 478.1397.

For compound 1v:
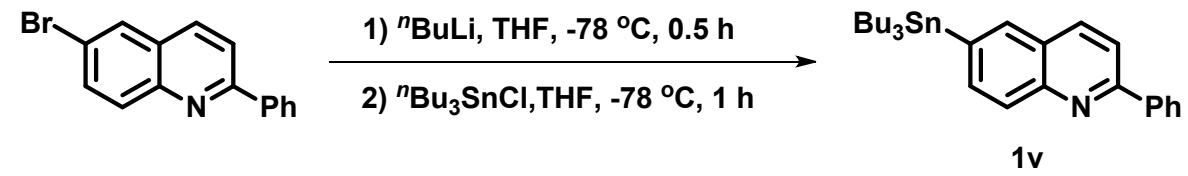

To a solution of 6-bromo-2-phenylquinoline (3.0 mmol, 1.0 equiv.) in THF (6 $\mathrm{mL})$ in flask was added n-butyllithium $\left(3.3 \mathrm{~mol}, 1.6 \mathrm{M}\right.$ in THF) at $-78{ }^{\circ} \mathrm{C}$ under argon. The mixture was stirred at $-78{ }^{\circ} \mathrm{C}$ for $0.5 \mathrm{~h}$ before ${ }^{n} \mathrm{Bu} 3 \mathrm{SnCl}$ (3.3 mmol, 1.1 equiv) was added. The mixture was allowed to stir for another $1 \mathrm{~h}$ at $-78^{\circ} \mathrm{C}$ before quenching with saturated aqueous $\mathrm{NH}_{4} \mathrm{Cl}(10 \mathrm{~mL})$. The reaction mixture was then extracted with EtOAc $(3 \times 10 \mathrm{~mL})$. The combined organic phase was washed with brine $(30 \mathrm{~mL})$, dried with anhydrous $\mathrm{Na}_{2} \mathrm{SO}_{4}$ and concentrated in vacuo. The residue was purified by chromatography on silica gel (eluent: petroleum ether/EtOAc $=100: 1$ ) to afford the title compound $\mathbf{1 v}$ as a slight yellow oil in 64\% yield $(950 \mathrm{mg}) .{ }^{1} \mathrm{H}$ NMR (400 MHz, $\left.\mathrm{CDCl}_{3}\right) \delta 8.23-8.14(\mathrm{~m}, 4 \mathrm{H}), 7.95(\mathrm{~s}, 1 \mathrm{H}), 7.88(\mathrm{~d}, J=8.8 \mathrm{~Hz}, 1 \mathrm{H}), 7.86(\mathrm{~d}, J=8.4$ $\mathrm{Hz}, 1 \mathrm{H}), 7.55$ (t, $J=7.6 \mathrm{~Hz}, 2 \mathrm{H}), 7.48(\mathrm{t}, J=7.2 \mathrm{~Hz}, 1 \mathrm{H}), 1.70-1.56(\mathrm{~m}, 6 \mathrm{H}), 1.45-$ $1.36(\mathrm{~m}, 6 \mathrm{H}), 1.26-1.12(\mathrm{~m}, 6 \mathrm{H}), 0.94(\mathrm{t}, J=7.3 \mathrm{~Hz}, 9 \mathrm{H}) .{ }^{13} \mathrm{C}\left\{{ }^{1} \mathrm{H}\right\} \mathrm{NMR}(101 \mathrm{MHz}$, $\left.\mathrm{CDCl}_{3}\right) \delta 157.3,148.4,141.0,140.0,137.2,136.5,136.1,129.3,128.9,128.6,127.7$, 127.1, 119.0, 29.3, 27.5, 13.8, 9.9. HRMS (ESI-TOF) m/z: $[\mathrm{M}+\mathrm{H}]^{+}$calculated for $\mathrm{C}_{27} \mathrm{H}_{38} \mathrm{NSn}^{+}$496.2026; found: 496.2041 .

\section{For compound 1w:}




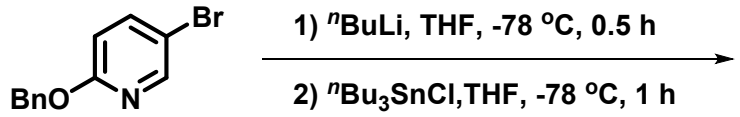

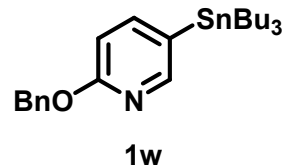

$1 w$

To a solution of 2-(benzyloxy)-5-bromopyridine ( $4.0 \mathrm{mmol}, 1.0$ equiv.) in THF $(8 \mathrm{~mL})$ in flask was added n-butyllithium $\left(4.4 \mathrm{~mol}, 1.6 \mathrm{M}\right.$ in THF) at $-78{ }^{\circ} \mathrm{C}$ under argon. The mixture was stirred at $-78{ }^{\circ} \mathrm{C}$ for $0.5 \mathrm{~h}$ before ${ }^{n} \mathrm{Bu}_{3} \mathrm{SnCl}(4.4 \mathrm{mmol}, 1.1$ equiv) was added. The mixture was allowed to stir for another $1 \mathrm{~h}$ at $-78^{\circ} \mathrm{C}$ before quenching with saturated aqueous $\mathrm{NH}_{4} \mathrm{Cl}(10 \mathrm{~mL})$. The reaction mixture was then extracted with EtOAc $(3 \times 10 \mathrm{~mL})$. The combined organic phase was washed with brine $(30 \mathrm{~mL})$, dried with anhydrous $\mathrm{Na}_{2} \mathrm{SO}_{4}$ and concentrated in vacuo. The residue was purified by chromatography on silica gel (eluent: petroleum ether/EtOAc $=60: 1$ ) to afford the title compound $\mathbf{1 w}$ as a colorless oil in $81 \%$ yield $(1.53 \mathrm{~g}) .{ }^{1} \mathrm{H}$ NMR (400 $\left.\mathrm{MHz}, \mathrm{CDCl}_{3}\right) \delta 8.18(\mathrm{~s}, 1 \mathrm{H}), 7.65(\mathrm{dd}, J=8.1,1.6 \mathrm{~Hz}, 1 \mathrm{H}), 7.48(\mathrm{~d}, J=7.5 \mathrm{~Hz}, 2 \mathrm{H})$, 7.39 (t, $J=7.4 \mathrm{~Hz}, 2 \mathrm{H}), 7.32(\mathrm{t}, J=7.2 \mathrm{~Hz}, 1 \mathrm{H}), 6.83(\mathrm{~d}, J=8.1 \mathrm{~Hz}, 1 \mathrm{H}), 5.39(\mathrm{~s}, 2 \mathrm{H})$, $1.62-1.47(\mathrm{~m}, 6 \mathrm{H}), 1.41-1.27(\mathrm{~m}, 6 \mathrm{H}), 1.14-1.01(\mathrm{~m}, 6 \mathrm{H}), 0.90(\mathrm{t}, J=7.3 \mathrm{~Hz}, 9 \mathrm{H})$. ${ }^{13} \mathrm{C}\left\{{ }^{1} \mathrm{H}\right\}$ NMR $\left(101 \mathrm{MHz}, \mathrm{CDCl}_{3}\right) \delta 163.9,153.2,146.4,137.6,128.6,128.1,127.9$, 127.5, 111.8, 67.4, 29.2, 27.5, 13.8, 9.7. HRMS (ESI-TOF) m/z: $[\mathrm{M}+\mathrm{H}]^{+}$Calculated for $\mathrm{C}_{24} \mathrm{H}_{38} \mathrm{NOSn}^{+}$: 476.1975; Found 476.1970.

\section{For compound 1y:}
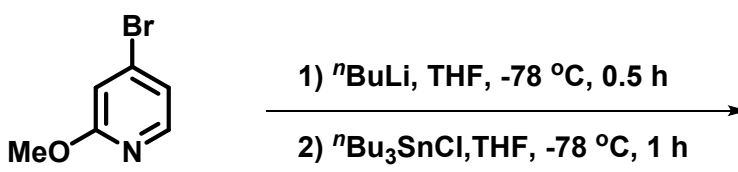

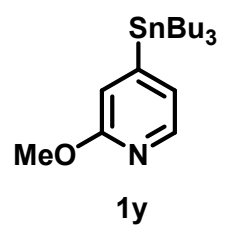

To a solution of 4-bromo-2-methoxypyridine (5.0 mmol, 1.0 equiv.) in THF (10 $\mathrm{mL})$ in flask was added n-butyllithium $\left(5.5 \mathrm{~mol}, 1.6 \mathrm{M}\right.$ in THF) at $-78^{\circ} \mathrm{C}$ under argon. The mixture was stirred at $-78{ }^{\circ} \mathrm{C}$ for $0.5 \mathrm{~h}$ before ${ }^{n} \mathrm{Bu}_{3} \mathrm{SnCl}(5.5 \mathrm{mmol}, 1.1$ equiv) was added. The mixture was allowed to stir for another $1 \mathrm{~h}$ at $-78^{\circ} \mathrm{C}$ before quenching with saturated aqueous $\mathrm{NH}_{4} \mathrm{Cl}(10 \mathrm{~mL})$. The reaction mixture was then extracted with EtOAc $(3 \times 10 \mathrm{~mL})$. The combined organic phase was washed with brine $(30 \mathrm{~mL})$, dried with anhydrous $\mathrm{Na}_{2} \mathrm{SO}_{4}$ and concentrated in vacuo. The residue was purified by 
chromatography on silica gel (petroleum ether/EtOAc $=20: 1$ ) to afford the title compound $1 \mathrm{y}$ as a colorless oil in $66 \%$ yield $(1.32 \mathrm{~g}) .{ }^{1} \mathrm{H}$ NMR $\left(400 \mathrm{MHz}, \mathrm{CDCl}_{3}\right) \delta$ $8.07(\mathrm{~d}, J=4.9 \mathrm{~Hz}, 1 \mathrm{H}), 6.93(\mathrm{~d}, J=4.8 \mathrm{~Hz}, 1 \mathrm{H}), 6.86(\mathrm{~s}, 1 \mathrm{H}), 3.92(\mathrm{~s}, 3 \mathrm{H}), 1.60-$ $1.46(\mathrm{~m}, 6 \mathrm{H}), 1.38-1.25(\mathrm{dd}, J=14.5,7.4 \mathrm{~Hz}, 6 \mathrm{H}), 1.14-0.99(\mathrm{~m}, 6 \mathrm{H}), 0.88(\mathrm{t}, J=$ $7.3 \mathrm{~Hz}, 9 \mathrm{H}) .{ }^{13} \mathrm{C}\left\{{ }^{1} \mathrm{H}\right\} \mathrm{NMR}\left(101 \mathrm{MHz}, \mathrm{CDCl}_{3}\right) \delta 163.1,155.7,145.2,124.3,118.8$, 53.0, 29.0, 27.3, 13.6, 9.6. HRMS (ESI-TOF) $\mathrm{m} / \mathrm{z}:[\mathrm{M}+\mathrm{H}]^{+}$Calculated for $\mathrm{C}_{18} \mathrm{H}_{34} \mathrm{NOSn}^{+}$: 400.1662; Found 400.1653.

Synthetic procedures for ethyl $(E)-4-b r o m o-4,4-d i f l u o r o b u t-2-e n o a t e ~(2 b)^{2 a}$ :<smiles>CCOC(=O)C=CC(F)(F)Br</smiles>

Step A: To a solution of lithium bis(trimethylsilyl)amide (100 $\mathrm{ml}$ of a $1 \mathrm{M}$ solution in THF, $100 \mathrm{mmol})$ was added a mixture of EtOAc $(8.5 \mathrm{ml}, 95 \mathrm{mmol})$ in THF $(10 \mathrm{ml})$ slowly at $-78{ }^{\circ} \mathrm{C}$ under argon with stirring over one hour at the same temperature. A mixture of ethyl 2-bromo-2,2-difluroacetate $(10 \mathrm{~g}, 50 \mathrm{mmol})$ in THF $(10 \mathrm{~mL})$ was charged over one hour at the same temperature. The reaction mixture was quenched with a saturated aqueous solution of $\mathrm{NH}_{4} \mathrm{Cl}(75 \mathrm{ml})$ forming a slurry, the cooling bath was removed and the reaction mixture was allowed to stir at $\mathrm{rt}$ overnight. The mixture was acidified with aqueous $\mathrm{HCl}(1 \mathrm{M})$ and the layers separated. The aqueous layer was extracted with EtOAc, and the combined organic phase was washed with aqueous $\mathrm{HCl}(1 \mathrm{M})$ and brine, dried over anhydrous $\mathrm{Na}_{2} \mathrm{SO}_{4}$ and concentrated to afford slight yellow residue $(9.7 \mathrm{~g})$.

Step B: To a solution of the residue from step A in toluene $(100 \mathrm{ml})$ was added sodium borohydride $(1.89 \mathrm{~g}, 50 \mathrm{mmol})$ portion-wise in an ice bath with stirring. After 15 minutes, the ice bath was removed and the mixture was allowed to stir at room temperature overnight. The mixture was filtered and the filter residue was washed with toluene, the filtrates were combined, cooled in an ice bath and acidified with $\mathrm{HCl}$ (1M). The layers were separated and the aqueous layer was extracted with EtOAc. 
The combined organic phase was washed with brine, dried over anhydrous $\mathrm{Na}_{2} \mathrm{SO}_{4}$, filtered, and concentrated to afford slight yellow oil (7.96 g).

Step C: The residue obtained from step B was dissolved in DCM $(100 \mathrm{ml})$ and TEA (4.5 mL, $32.5 \mathrm{mmol})$ and the mixture was cooled in an ice bath. A solution of methanesulfonic chloride $(3.79 \mathrm{ml}, 48.8 \mathrm{mmol})$ in DCM $(25 \mathrm{ml})$ was charged at 5-10 ${ }^{\circ} \mathrm{C}$. The cooling bath was then removed and the mixture was stirred at room temperature for $4 \mathrm{~h}$. The mixture was cooled again in an ice bath, and TEA $(7.6 \mathrm{ml}$, $65 \mathrm{mmol}$ ) was charged dropwise. After stirring at room temperature overnight, water $(25 \mathrm{ml})$ was added to the mixture, the layers were separated. The organic layer was washed with $\mathrm{HCl}\left(1 \mathrm{~N}, 25 \mathrm{ml}\right.$, twice), brine, dried over anhydrous $\mathrm{Na}_{2} \mathrm{SO}_{4}$, filtered and concentrated under reduced pressure. The obtained residue was distilled under reduced pressure $\left(-0.1 \mathrm{MPa}, 80{ }^{\circ} \mathrm{C}\right)$ to afford $\mathbf{2 b}$ as colorless oil in $42 \%$ overall yield (4.79 g). ${ }^{1} \mathrm{H}$ NMR (400 MHz, $\left.\mathrm{CDCl}_{3}\right) \delta 6.98(\mathrm{dt}, J=15.6,10.2 \mathrm{~Hz}, 1 \mathrm{H}), 6.29$ (dt, $J=$ 15.5, 1.6 Hz, 1H), $4.26(\mathrm{q}, J=7.1 \mathrm{~Hz}, 2 \mathrm{H}), 1.32(\mathrm{t}, J=7.1 \mathrm{~Hz}, 3 \mathrm{H}) .{ }^{13} \mathrm{C}\left\{{ }^{1} \mathrm{H}\right\} \mathrm{NMR}$ $\left(101 \mathrm{MHz}, \mathrm{CDCl}_{3}\right) \delta 164.2,138.6\left(\mathrm{C}-\mathrm{F}, \mathrm{t},{ }^{2} J_{C-F}=25.6 \mathrm{~Hz}\right), 124.4\left(\mathrm{C}-\mathrm{F}, \mathrm{t},{ }^{3} J_{C-F}=6.7\right.$ $\mathrm{Hz}), 115.3\left(\mathrm{C}-\mathrm{F}, \mathrm{t},{ }^{1} J_{\mathrm{C}-\mathrm{F}}=302.6 \mathrm{~Hz}\right), 61.8,14.2 .{ }^{19} \mathrm{~F} \mathrm{NMR}\left(376 \mathrm{MHz}, \mathrm{CDCl}_{3}\right) \delta$ $-49.67(\mathrm{dd}, J=10.2,1.3 \mathrm{~Hz}, 2 \mathrm{~F})$. HRMS (EI-MS) m/z: [M - H] Calculated for $\mathrm{C}_{6} \mathrm{H}_{6} \mathrm{BrF}_{2} \mathrm{O}_{2}^{-}:$:226.9517; Found 226.9514 .

Synthetic procedure for ethyl (E)-4-bromo-4,4-difluoro-3-phenylbut-2-enoate $(2 \mathrm{c})^{2 \mathrm{~b}}$ :

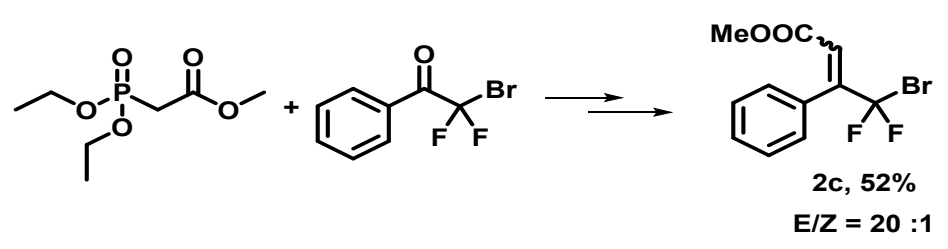

To a mixture of diethylphosphonoacetic acid methyl ester (3.16 g, $15 \mathrm{mmol})$ in THF (25 mL) was added $\mathrm{NaH}(655 \mathrm{mg}, 55 \%$ in mineral oil, $15 \mathrm{mmol})$ in portions under argon at $-20{ }^{\circ} \mathrm{C}$ over $1 \mathrm{~h}$. The reaction mixture was then warmed to $0{ }^{\circ} \mathrm{C}$, and stirred for 1 h. 2-Bromo-2,2-difluoro-1-phenylethanone (2.33 g, $10 \mathrm{mmol})$ was added slowly to the reaction mixture at $0{ }^{\circ} \mathrm{C}$ for $0.5 \mathrm{~h}$. The mixture was stirred at ambient temperature for $4 \mathrm{~h}$, quenched with $4 \mathrm{~N} \mathrm{HCl}(10 \mathrm{~mL})$, and extracted with EtOAc. The 
combined organic phase was washed with brine, dried over anhydrous $\mathrm{Na}_{2} \mathrm{SO}_{4}$, filtered, and concentrated. The residue was purified with silica gel column chromatography (eluent: petroleum ether/EtOAc $=20: 1$ ) to give $\mathbf{2} \mathbf{c}$ as a slight yellow solid in 58\% yield (1.67 g, $E / Z=20: 1) .{ }^{1} \mathrm{H}$ NMR $\left(400 \mathrm{MHz}, \mathrm{CDCl}_{3}\right) \delta 7.46-7.38(\mathrm{~m}$, 3H), 7.33 (d, $J=7.1 \mathrm{~Hz}, 2 \mathrm{H}), 6.52(\mathrm{~s}, 1 \mathrm{H}), 3.59$ (s, 3H). ${ }^{13} \mathrm{C}\left\{{ }^{1} \mathrm{H}\right\}$ NMR (101 MHz, $\left.\mathrm{CDCl}_{3}\right) \delta 164.6,149.4\left(\mathrm{C}-\mathrm{F}, \mathrm{t},{ }^{2} J_{C-F}=21.4 \mathrm{~Hz}\right), 131.5,129.5,129.4,128.2,121.3$ $\left(\mathrm{C}-\mathrm{F}, \mathrm{t},{ }^{3} J_{\mathrm{C}-\mathrm{F}}=7.0 \mathrm{~Hz}\right), 117.8\left(\mathrm{C}-\mathrm{F}, \mathrm{t},{ }^{1} J_{\mathrm{C}-\mathrm{F}}=307.5 \mathrm{~Hz}\right), 52.1 .{ }^{19} \mathrm{~F}$ NMR $(376 \mathrm{MHz}$, $\left.\mathrm{CDCl}_{3}\right) \delta-50.72(\mathrm{~s}, 2 \mathrm{~F})$. The spectrum was consistent with the literature ${ }^{2 \mathrm{~b}}$.

\section{Synthetic procedure for diethyl (E)-(3-bromo-3,3-difluoro prop-1-en-1-yl)} -phosphonate $(2 \mathrm{~d})^{2 \mathrm{c}}$ :

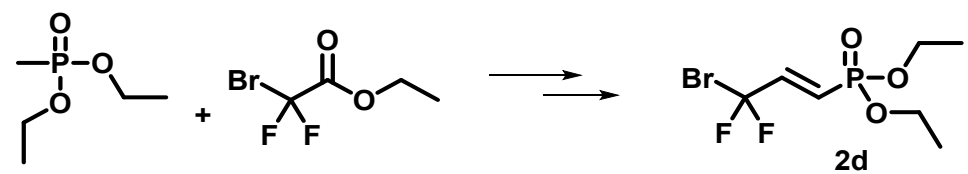

Step A: To a solution of lithium diisopropylamide ( $3 \mathrm{ml}$ of a $2 \mathrm{M}$ solution in THF, $6 \mathrm{mmol})$ was added a mixture of diethyl methylphosphonate $(0.73 \mathrm{ml}, 5 \mathrm{mmol})$ in THF (2 ml) slowly at $-78{ }^{\circ} \mathrm{C}$ under argon with stirring over $1 \mathrm{~h}$. A mixture of ethyl 2-bromo-2,2-difluoroacetate (1.22 g, $6 \mathrm{mmol})$ in THF $(2 \mathrm{~mL})$ was charged over $1 \mathrm{~h}$ at the same temperature. The mixture was quenched with aqueous $\mathrm{HCl}(1 \mathrm{M})$ and the layers were separated, extracted with EtOAc, and the combined organic phase was washed with aqueous $\mathrm{HCl}(1 \mathrm{M})$ and brine, dried over anhydrous $\mathrm{Na}_{2} \mathrm{SO}_{4}$ and concentrated to afford a yellow residue $(375 \mathrm{mg})$.

Step B: To a solution of the residue obtained from step A in toluene $(2.5 \mathrm{ml})$ was added sodium borohydride $(57 \mathrm{mg}, 1.5 \mathrm{mmol})$ portion-wise in an ice bath with stirring. After $15 \mathrm{~min}$, the ice bath was removed and the mixture was allowed to stir at room temperature overnight. The mixture was filtered and washed with toluene. The combined organic phase was cooled in an ice bath and acidified with $\mathrm{HCl}(1 \mathrm{M})$. After separation, the aqueous phase was extracted with EtOAc, and the combined organic phase was washed with brine, dried over anhydrous $\mathrm{Na}_{2} \mathrm{SO}_{4}$, filtered, and concentrated to afford a yellow oil $(330 \mathrm{mg})$. 
Step C: The residue obtained from step B was combined with DCM $(3.5 \mathrm{ml})$ and TEA (167 $\mu \mathrm{L}, 1.2 \mathrm{mmol})$ and cooled in an ice bath. A solution of methanesulfonic chloride $(140 \mu \mathrm{l}, 1.8 \mathrm{mmol})$ in DCM $(1 \mathrm{ml})$ was charged at $5-10{ }^{\circ} \mathrm{C}$. After stirring at room temperature for $4 \mathrm{~h}$, the mixture was then cooled in an ice bath and TEA $(330 \mu \mathrm{l}$, $2.4 \mathrm{mmol}$ ) was charged dropwise. The cooling bath was removed and the mixture was allowed to stir at room temperature overnight. The reaction was quenched by ice water, and the organic layer was washed with $1 \mathrm{~N} \mathrm{HCl}$, brine, dried over anhydrous $\mathrm{Na}_{2} \mathrm{SO}_{4}$, filtered and concentrated under reduced pressure. The residue was purified with silica gel column chromatography (eluent: petroleum ether/EtOAc $=3: 1$ ) to give product $\mathbf{2 d}$ as a slight yellow oil in $18 \%$ overall yield $(263 \mathrm{mg}) .{ }^{1} \mathrm{H}$ NMR (400 MHz, $\left.\mathrm{CDCl}_{3}\right) \delta 6.89-6.73(\mathrm{~m}, 1 \mathrm{H}), 6.26-6.15(\mathrm{~m}, 1 \mathrm{H}), 4.20-4.03(\mathrm{~m}, 4 \mathrm{H}), 1.39-1.30$ $(\mathrm{m}, 6 \mathrm{H}) .{ }^{13} \mathrm{C}\left\{{ }^{1} \mathrm{H}\right\} \mathrm{NMR}\left(101 \mathrm{MHz}, \mathrm{CDCl}_{3}\right) \delta 142.0\left(\mathrm{C}-\mathrm{F}, \mathrm{C}-\mathrm{P}, \mathrm{td},{ }^{2} J_{\mathrm{C}-F}=25.9 \mathrm{~Hz}\right.$, $\left.{ }^{3} J_{C-P}=7.4 \mathrm{~Hz}\right), 121.9\left(\mathrm{C}-\mathrm{P}, \mathrm{C}-\mathrm{F}, \mathrm{dt},{ }^{1} J_{\mathrm{C}-\mathrm{P}}=187.9 \mathrm{~Hz},{ }^{3} J_{\mathrm{C}-\mathrm{F}}=6.0 \mathrm{~Hz}\right), 115.1(\mathrm{C}-\mathrm{F}, \mathrm{C}-\mathrm{P}$, td, $\left.{ }^{1} J_{C-F}=303.8 \mathrm{~Hz},{ }^{2} J_{C-P}=30.3 \mathrm{~Hz}\right), 62.8\left(\mathrm{C}-\mathrm{P}, \mathrm{d},{ }^{2} J_{\mathrm{C}-\mathrm{P}}=5.8 \mathrm{~Hz}\right), 16.5\left(\mathrm{C}-\mathrm{P}, \mathrm{d},{ }^{3} J_{C-P}\right.$ $=6.1 \mathrm{~Hz}) .{ }^{19} \mathrm{~F}$ NMR $\left(376 \mathrm{MHz}, \mathrm{CDCl}_{3}\right) \delta-50.56(\mathrm{~d}, J=9.2 \mathrm{~Hz}, 2 \mathrm{~F}) .{ }^{31} \mathrm{P}\left\{{ }^{1} \mathrm{H}\right\} \mathrm{NMR}$ $\left(162 \mathrm{MHz}, \mathrm{CDCl}_{3}\right) \delta 13.25$ (s, 1P). HRMS (ESI-TOF) m/z: [M+H] Calculated for $\mathrm{C}_{7} \mathrm{H}_{13} \mathrm{BrF}_{2} \mathrm{O}_{3} \mathrm{P}^{+}$292.9754; Found 292.9757.

\section{Synthesis of (3-bromo-3,3-difluoroprop-1-en-2-yl)benzene (2e $)^{2 b}$ :}

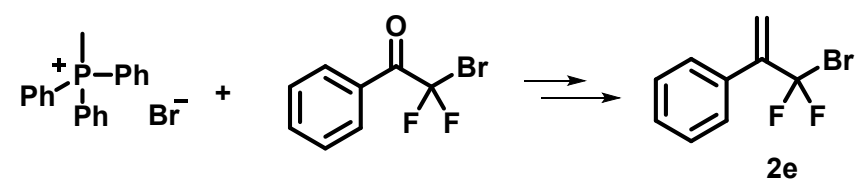

To a mixture of methyltriphenylphosphonium bromide $(5.05 \mathrm{~g}, 14 \mathrm{mmol})$ in THF $(60 \mathrm{~mL})$ was added NaHMDS ( $7 \mathrm{~mL}, 2 \mathrm{M}$ in THF, $14 \mathrm{mmol})$ under argon at $-78^{\circ} \mathrm{C}$ for $1 \mathrm{~h}$. The reaction mixture was then warmed to $0{ }^{\circ} \mathrm{C}$ and stirred for $1 \mathrm{~h}$ at the same temperature. 2-bromo-2,2-difluoro-1-phenylethan-1-one (2.33 g, $10 \mathrm{mmol})$ was then added slowly to the reaction mixture at $0{ }^{\circ} \mathrm{C}$ and the mixture was allowed to stir for over $0.5 \mathrm{~h}$. The mixture was stirred at room temperature for another $1 \mathrm{~h}$. Then, the reaction mixture was quenched with $4 \mathrm{~N} \mathrm{HCl}(10 \mathrm{~mL})$ and extracted with EtOAc. The combined organic phase was washed with brine, dried over with anhydrous $\mathrm{Na}_{2} \mathrm{SO}_{4}$, 
filtered, and concentrated. The residue was purified with silica gel column chromatography (eluent: petroleum ether) to give $\mathbf{2 e}$ as a colorless oil in $33 \%$ yield (756 mg). ${ }^{1} \mathrm{H}$ NMR (400 MHz, $\left.\mathrm{CDCl}_{3}\right) \delta 7.53$ - 7.47 (m, 2H), 7.45 - 7.37 (m, 3H), $5.90(\mathrm{~s}, 1 \mathrm{H}), 5.55(\mathrm{t}, J=1.7 \mathrm{~Hz}, 1 \mathrm{H}) .{ }^{13} \mathrm{C}\left\{{ }^{1} \mathrm{H}\right\} \mathrm{NMR}\left(101 \mathrm{MHz}, \mathrm{CDCl}_{3}\right) \delta 145.8(\mathrm{C}-\mathrm{F}$, $\left.\mathrm{t},{ }^{2} J_{C-F}=20.8 \mathrm{~Hz}\right), 134.8,129.1,128.5,128.4,118.5\left(\mathrm{C}-\mathrm{F}, \mathrm{t},{ }^{3} J_{C-F}=7.4 \mathrm{~Hz}\right), 118.3$ $\left(\mathrm{C}-\mathrm{F}, \mathrm{t},{ }^{1} J_{\mathrm{C}-\mathrm{F}}=306.5 \mathrm{~Hz}\right) .{ }^{19} \mathrm{~F} \mathrm{NMR}\left(376 \mathrm{MHz}, \mathrm{CDCl}_{3}\right) \delta-46.13(\mathrm{~s}, 2 \mathrm{~F})$. The spectrum was consistent with the literature ${ }^{2 b}$.

\section{For compound 7f:}

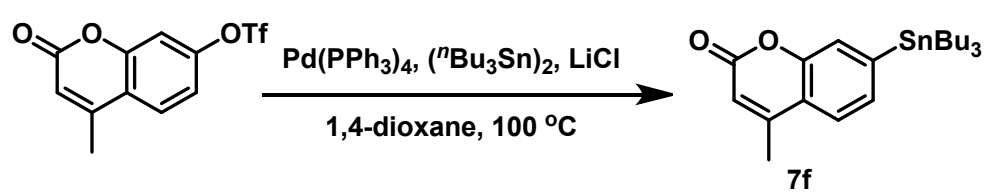

To a solution of 4-methyl-2-oxo- $2 H$-chromen-7-yltrifluoromethanesulfonate (246 mg, $0.8 \mathrm{mmol}, 1.0$ equiv.) in 1,4-dioxane (5 mL) was added $\mathrm{LiCl}$ (168 mg, 4.0 mmol, 5.0 equiv.), $\mathrm{Pd}\left(\mathrm{PPh}_{3}\right)_{4}(46 \mathrm{mg}, 0.04 \mathrm{mmol}, 5.0 \mathrm{~mol} \%)$ and bis(tri- $n$-butyltin) (0.82 mL, $1.6 \mathrm{mmol}, 2.0$ equiv.) sequentially at room temperature. After stirring for $12 \mathrm{~h}$ at $100{ }^{\circ} \mathrm{C}$ (oil bath), the mixture was cooled to rt and concentrated in vacuo. The residue was purified by chromatography on silica gel (petroleum ether/EtOAc $=10: 1$ ) to afford the title compound $7 \mathbf{f}$ as a slight yellow oil in 45\% yield (162 mg). ${ }^{1} \mathrm{H}$ NMR $\left(400 \mathrm{MHz}, \mathrm{CDCl}_{3}\right): \delta 7.54(\mathrm{~d}, J=7.6 \mathrm{~Hz}, 1 \mathrm{H}), 7.45(\mathrm{~s}, 1 \mathrm{H}), 7.39(\mathrm{~d}, J=7.7 \mathrm{~Hz}, 1 \mathrm{H})$, $6.28(\mathrm{~s}, 1 \mathrm{H}), 2.43(\mathrm{~s}, 3 \mathrm{H}), 1.62-1.48(\mathrm{~m}, 6 \mathrm{H}), 1.39-1.25(\mathrm{~m}, 6 \mathrm{H}), 1.15-1.05(\mathrm{~m}$, $6 \mathrm{H}), 0.89(\mathrm{t}, J=7.3 \mathrm{~Hz}, 9 \mathrm{H}) .{ }^{13} \mathrm{C}\left\{{ }^{1} \mathrm{H}\right\} \mathrm{NMR}\left(101 \mathrm{MHz}, \mathrm{CDCl}_{3}\right): \delta$ 161.2, 152.9, $152.8,149.0,132.1,124.7,123.4,119.6,115.0,29.1,27.5,18.7,13.8,10.0$. HRMS (MALDI-TOF) m/z: [M+H] $]^{+}$calculated for $\mathrm{C}_{22} \mathrm{H}_{35} \mathrm{O}_{2} \mathrm{Sn}^{+}$451.1659; found: 451.1659 .

\section{Synthesis of compound 4a}

To a solution of $10 \%$ palladium(II) hexafluoroacetylactonate $(5.2 \mathrm{mg}, 0.01 \mathrm{mmol})$ in freshly distilled toluene $(1 \mathrm{ml})$ were added tributyl(naphthalen-2-yl)stannane 1a (0.1 mmol, 1.0 equiv) and 3-bromo-3,3-difluoropropene $\mathbf{2 a}(20.5 \mu \mathrm{L}, 0.2 \mathrm{mmol}, 2.0$ equiv) sequentially under argon atmosphere. The reaction mixture was heated to $70{ }^{\circ} \mathrm{C}$ 
(oil bath) for $12 \mathrm{~h}$. After cooling to room temperature, the mixture was diluted with EtOAc, filtered through a pad of anhydrous $\mathrm{Mg}_{2} \mathrm{SO}_{4}$ and concentrated. The residue was purified by chromatography on silica gel, eluting with petroleum ether to afford compound $4 \mathbf{a}$ as a colorless oil in $63 \%$ yield $(12.8 \mathrm{mg})$.

\section{Synthesis of compound 5a}

To a solution of $5 \% \mathrm{Pd}\left(\mathrm{PPh}_{3}\right)_{4}(5.78 \mathrm{mg}, 0.005 \mathrm{mmol})$ in freshly distilled toluene $(1.0 \mathrm{~mL})$ were added tributyl(naphthalen-2-yl)stannane $\mathbf{1 a}(0.25 \mathrm{mmol}, 2.5$ equiv) and 3-bromo-3,3-difluoropropene $\mathbf{2 a}(11 \mu \mathrm{L}, 0.1 \mathrm{mmol}, 1.0$ equiv) sequentially under argon atmosphere. The reaction mixture was heated to $70^{\circ} \mathrm{C}$ (oil bath) and stirred for $12 \mathrm{~h}$. After cooling to room temperature, the mixture was diluted with EtOAc, filtered through a pad of anhydrous $\mathrm{Mg}_{2} \mathrm{SO}_{4}$ and concentrated. The residue was purified by chromatography on silica gel, eluting with petroleum ether to afford compound $\mathbf{5 a}$ as a white solid in $33 \%$ yield $(10.3 \mathrm{mg})$.

\section{Transformations of $\alpha, \alpha$-Difluoallylation Product 8a}

Synthesis of compound 9: To a solution of $8 \mathbf{a}(33 \mathrm{mg}, 0.1 \mathrm{mmol}, 1.0$ equiv.) in acetone $(0.5 \mathrm{~mL})$ and $\mathrm{H}_{2} \mathrm{O}(0.1 \mathrm{~mL})$ were added $\mathrm{K}_{2} \mathrm{OsO}_{2}(\mathrm{OH})_{4}(1.84 \mathrm{mg}, 0.005 \mathrm{mmol}$, $5 \mathrm{~mol} \%$ ) and NMO (27 mg, $0.2 \mathrm{mmol}, 2.0$ equiv). The reaction mixture was stirred at room temperature for $24 \mathrm{~h}$ and diluted with EtOAc. The mixture was filtered and concentrated under vacuo. The residue was purified by silica gel chromatography (petroleum ether/EtOAc $=2: 1)$ to give compound 9 in $65 \%$ yield $(23.7 \mathrm{mg}$ ).

Synthesis of compound 10: To a solution of $10 \% \mathrm{Pd}(\mathrm{OH})_{2} / \mathrm{C}(1.4 \mathrm{mg}, 0.001 \mathrm{mmol}, 1$ mol\%) in EtOAc $(1 \mathrm{ml})$ was added $8 \mathbf{8}(33 \mathrm{mg}, 0.1 \mathrm{mmol}, 1.0$ equiv.). The flask was then filled with $\mathrm{H}_{2}(1 \mathrm{~atm})$ and stirred for $12 \mathrm{~h}$ at $60{ }^{\circ} \mathrm{C}$. After diluted with EtOAc, the mixture was filtered and concentrated under vacuo. The residue was purified with silica gel chromatography (petroleum ether/EtOAc $=10: 1$ ) to give the product $\mathbf{1 0}$ in $81 \%$ yield $(27.0 \mathrm{mg})$. 
Synthesis of compound 11: To a solution of $\mathrm{CuCl}(2.0 \mathrm{mg}, 0.02 \mathrm{mmol}, 20 \mathrm{~mol} \%)$ in THF (0.5 ml) were added $\mathrm{PCy}_{3}(5.6 \mathrm{mg}, 0.02 \mathrm{mmol}, 20 \mathrm{~mol} \%)$ and $\mathrm{NaO}^{t} \mathrm{Bu}(3.84 \mathrm{mg}$, $0.04 \mathrm{mmol}, 40 \mathrm{~mol} \%)$ under argon atmosphere. $\mathrm{B}_{2} \mathrm{Pin}_{2}(50.8 \mathrm{mg}, 0.2 \mathrm{mmol}, 2.0$ equiv.) and $8 \mathbf{a}$ ( $33 \mathrm{mg}, 0.1 \mathrm{mmol}, 1.0$ equiv.) were then added to the mixture. After stirring at $45^{\circ} \mathrm{C}$ for $12 \mathrm{~h}$, the reaction mixture was diluted with EtOAc, filtered and concentrated. The residue was purified with silica gel chromatography (eluent: petroleum ether/ EtOAc $=10: 1)$ to give the compound 11 in $54 \%$ yield $(23.7 \mathrm{mg})$.

\section{References}

(1) For synthesis of various tributyl(aryl)stannanes, see: (a) Tang, P.; Furuya, T. and Ritter, T. Silver-Catalyzed Late-Stage Fluorination. J. Am. Chem. Soc. 2010, 132, 12150-12154.; (b) Furuya, T.; Strom, A. E. and Ritter, T. Silver-Mediated Fluorination of Functionalized Aryl Stannanes. J. Am. Chem. Soc. 2009, 131, 1662-1663.; (c) Pickett, J. E.; Váradi, A.; Palmer, T. C.; Grinnell S. G.; Schrock, J. M.; Pasternak, G. W.; Karimov, R. R.; Majumdar, S. Mild, Pd-catalyzed Stannylation of Radioiodination Targets. Bio. Med. Chem. Lett. 2015, 25, 1761-1764.; (d) Torun, L.; Madras, B. K.; Meltzer, P. C. Synthesis and $\begin{array}{lll}\text { Structure-Activity } & \text { Relationship of }\end{array}$ 3-biaryl-8-oxabicyclo[3.2.1] octane-2-carboxylic Acid Methyl Esters. Bio. Med. Chem. Lett. 2012, 20, 2762-2772.; (e) Matsuoka, K.; Komami, N.; Kojima, M.; Yoshino T. and Matsunaga S. Synthesis of Heteroaryl Iodanes(III) via ipso-Substitution Reactions Using Iodine Triacetate Assisted by HFIP. Asian J. Org. Chem. 2019, 8, 1107 - 1110.; (f) Tan, X.; Zhou, Z.-J.; Zhang, J.-X.; Duan, X.-H. Efficient One-Pot Cross-Coupling of Two Aryl Halides by Stannylation/Stille Reaction in Water under Microwave Irradiation. Eur. J. Org. Chem. 2014, 5153-5157.

(2) For synthesis of BDFP derivatives, see: (a) Michael, B.; Stephan, V.; Hans Peter, N.; Tobias, K.; Alfred, S. Improved Process for Preparing Substituted Crotonic Acids. PCT Int. Appl. 2015177179, 26 Nov 2015.; (b) Min, Q.-Q.; Yin, Z.; Feng, Z.; Guo, W.-H. and Zhang, X. Highly Selective gem-Difluoroallylation of 
Organoborons with Bromodifluoromethylated Alkenes Catalyzed by Palladium. $J$. Am. Chem. Soc. 2014, 136, 1230-1233.; (c) Cen, W.; Shen, Y. New Synthesis of Fluorinated 2-Aminophosphonates. J. Flu. Chem. 1995, 72, 107-110.

(3) For synthesis of bioactive molecular derived aryltributyltins see: (a) Tang, P.; Furuya, T. and Ritter, T. Silver-Catalyzed Late-Stage Fluorination. J. Am. Chem. Soc. 2010, 132, 12150-12154.; (b) Furuya, T.; Strom, A. E. and Ritter, T. Silver-Mediated Fluorination of Functionalized Aryl Stannanes. J. Am. Chem. Soc. 2009, 131, 1662-1663.; (c) Sano, Y.; Motomura, T.; Yamamoto, F.; Fukuda, M.; Mukai, T.; Maeda, M.; 1-(3'-[125I] Iodophenyl)-3-methy-2-pyrazolin-5-one: Preparation, Solution Stability, and Biodistribution in Normal Mice. Chem. Pharm. Bull. 2010, 58, 1020-1025. 


\section{Copies of NMR Spectra Data}

${ }^{1} \mathrm{H}\left(400 \mathrm{MHz}, \mathrm{CDCl}_{3}\right)$ of $\mathbf{1 n}$

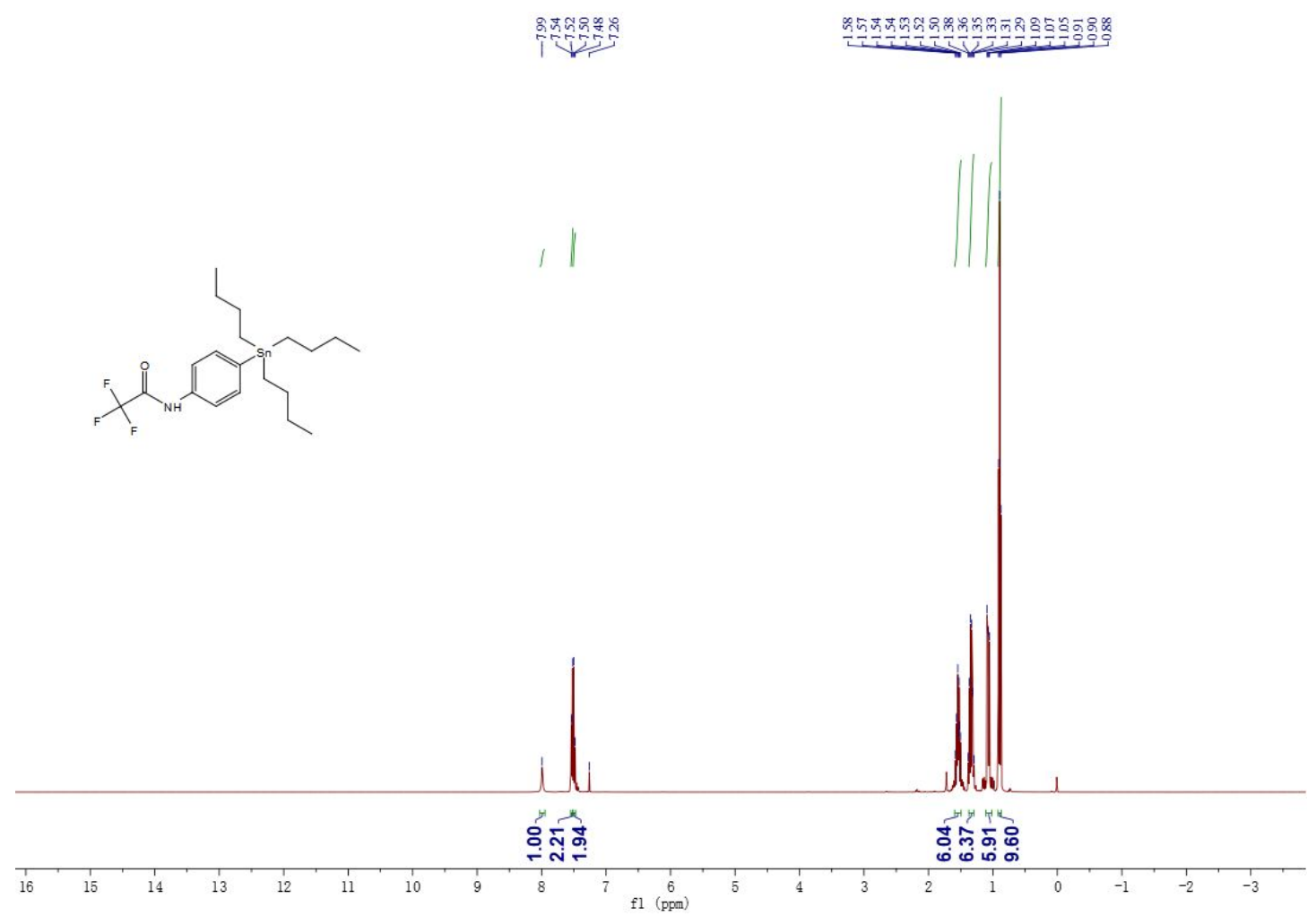

${ }^{19} \mathrm{~F}\left(376 \mathrm{MHz}, \mathrm{CDCl}_{3}\right)$ of $\mathbf{1 n}$

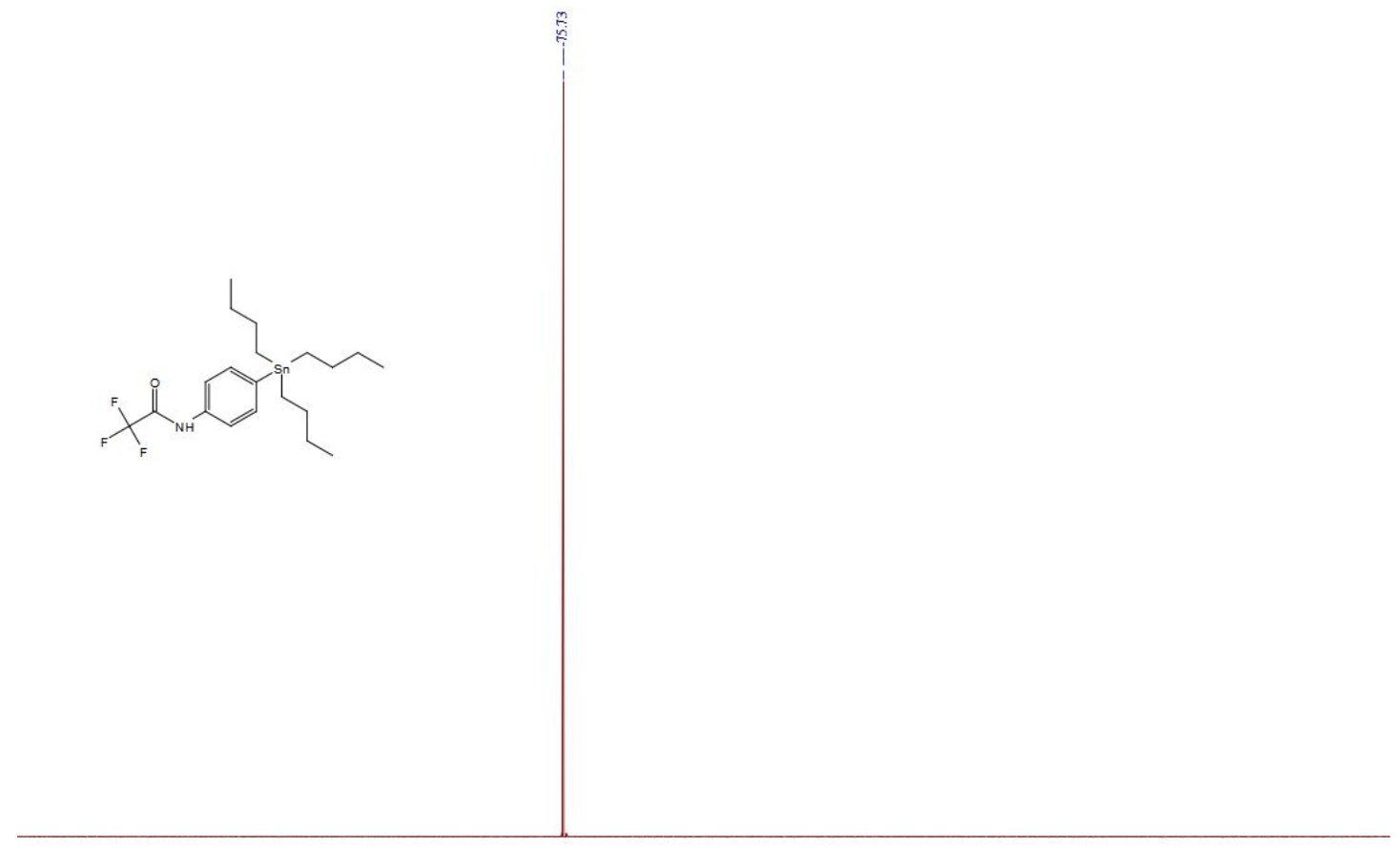

$\begin{array}{llllllllllllllllllllllllll}1 & 10 & 0 & -10 & -20 & -30 & -40 & -50 & -60 & -70 & -80 & -90 & -100 & -110 & -120 & -130 & -140 & -150 & -160 & -170 & -180 & -190 & -200 & -210\end{array}$ 
${ }^{13} \mathrm{C}\left\{{ }^{1} \mathrm{H}\right\}\left(101 \mathrm{MHz}, \mathrm{CDCl}_{3}\right)$ of $\mathbf{1 n}$
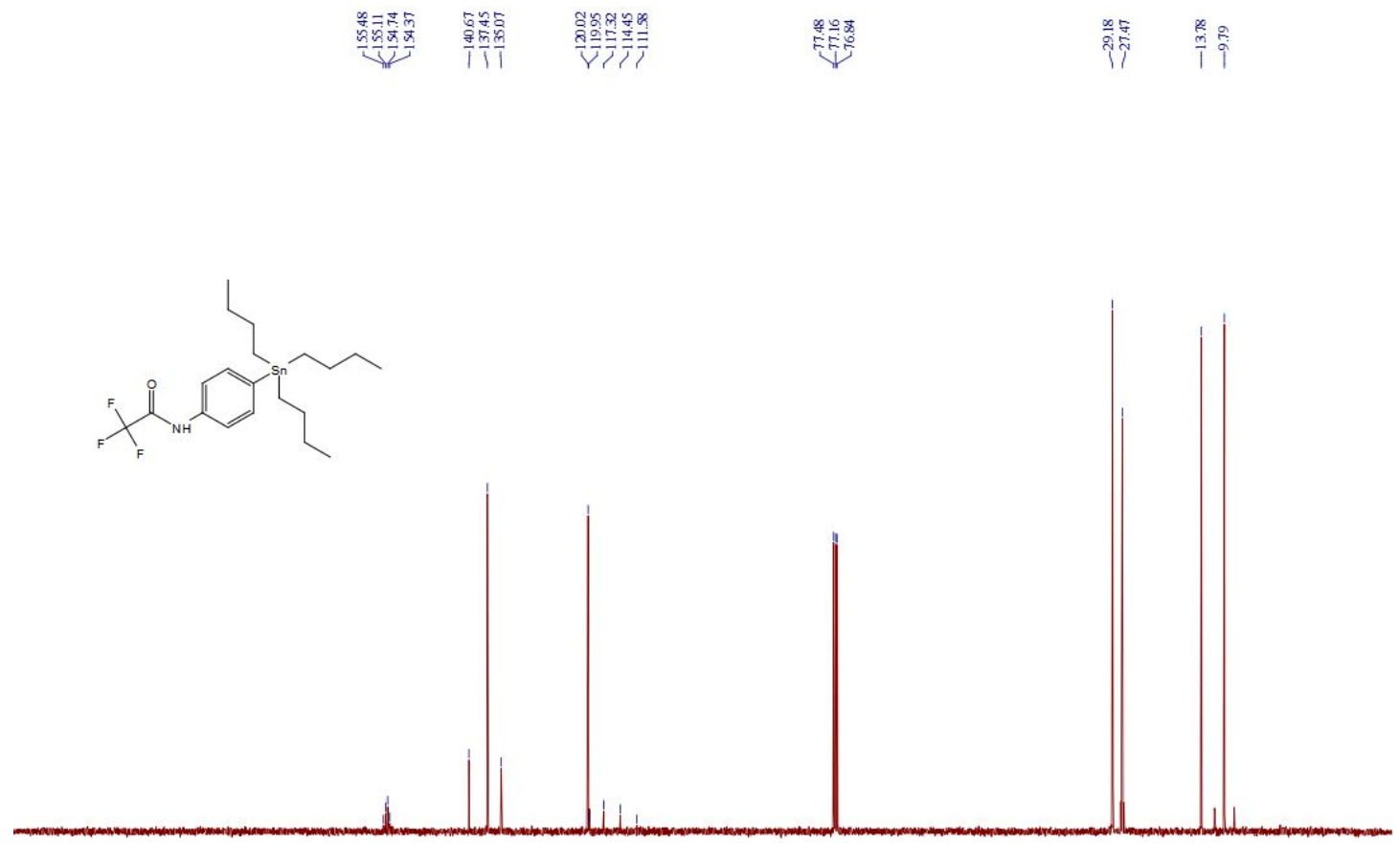

$\begin{array}{llllllllllll}210 & 200 & 190 & 180 & 170 & 160 & 150 & 140 & 130 & 120 & 110 & 100 \\ \mathrm{fl}(\mathrm{pmm})\end{array}$

${ }^{1} \mathrm{H}\left(400 \mathrm{MHz}, \mathrm{CDCl}_{3}\right)$ of $\mathbf{1 v}$

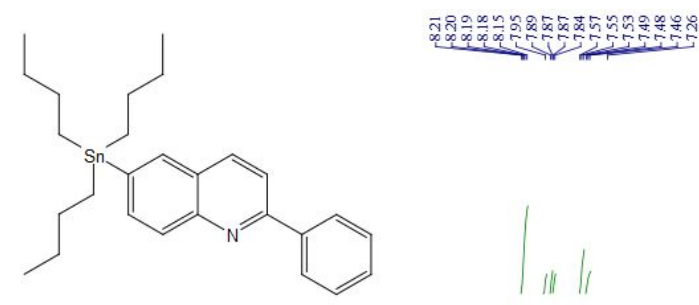

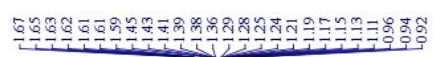
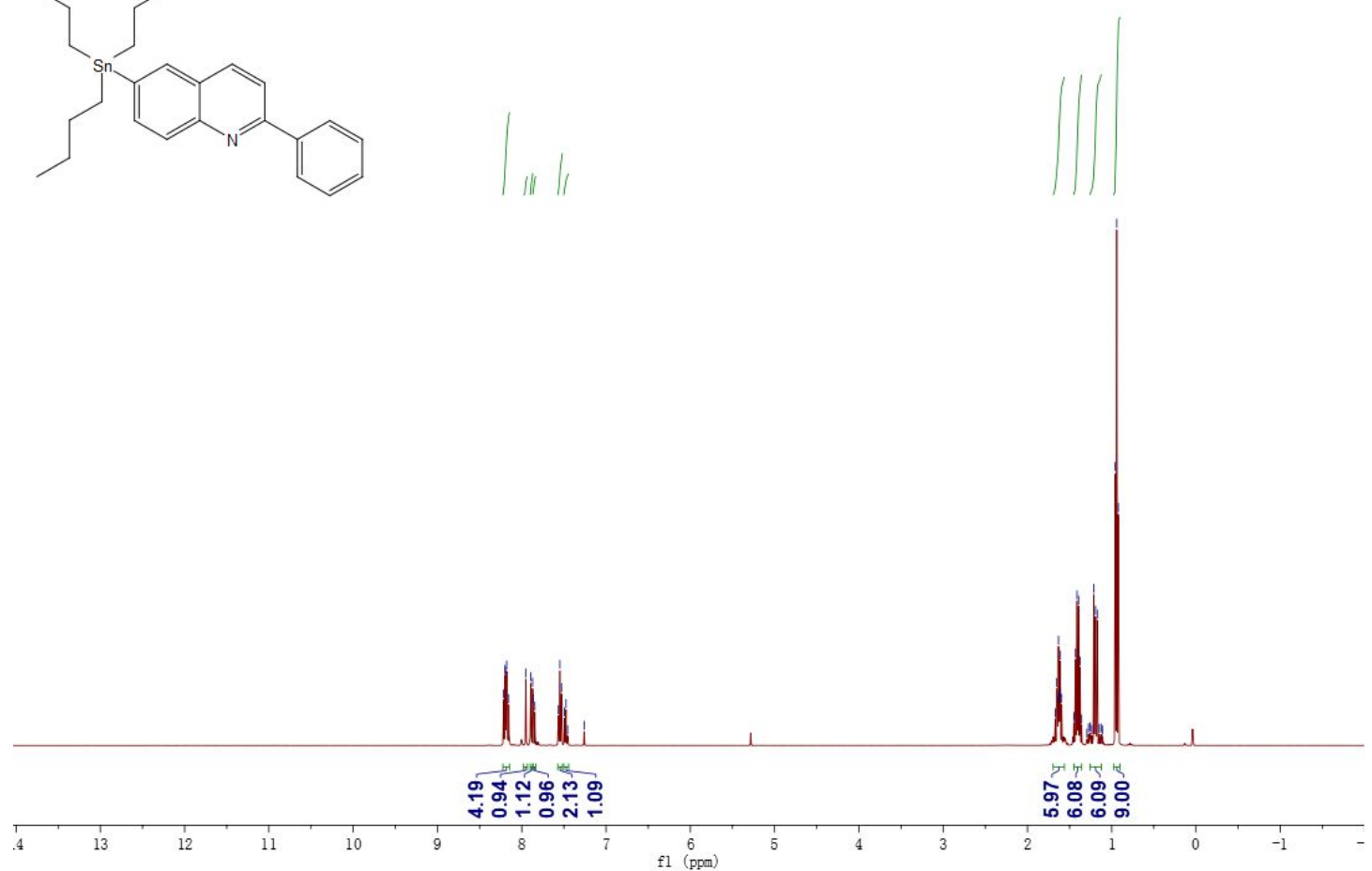
${ }^{13} \mathrm{C}\left\{{ }^{1} \mathrm{H}\right\}\left(101 \mathrm{MHz}, \mathrm{CDCl}_{3}\right)$ of $\mathbf{1 v}$

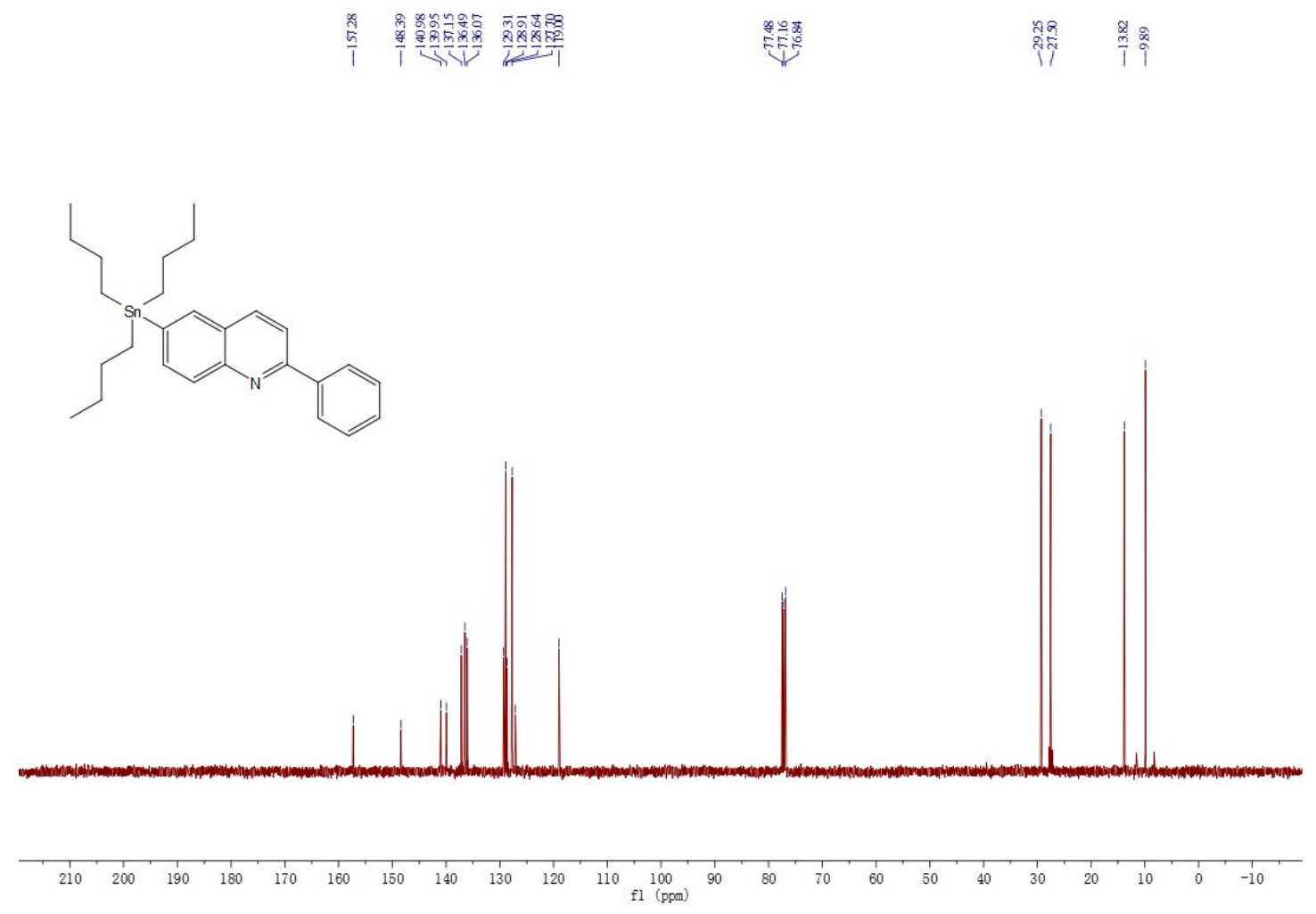

${ }^{1} \mathrm{H}\left(400 \mathrm{MHz}, \mathrm{CDCl}_{3}\right)$ of $\mathbf{1 w}$

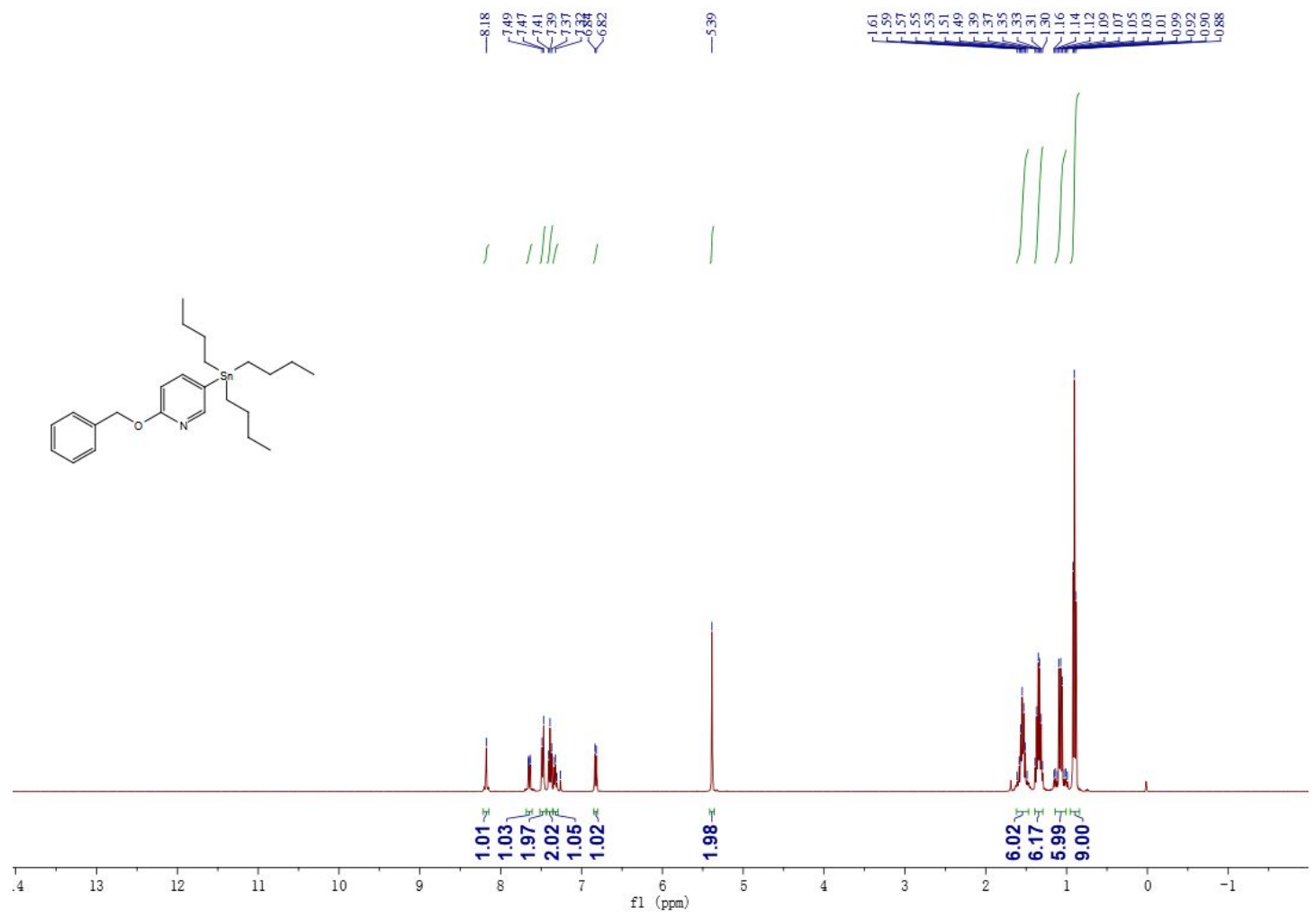


${ }^{13} \mathrm{C}\left\{{ }^{1} \mathrm{H}\right\}\left(101 \mathrm{MHz}, \mathrm{CDCl}_{3}\right)$ of $\mathbf{1} \mathbf{w}$
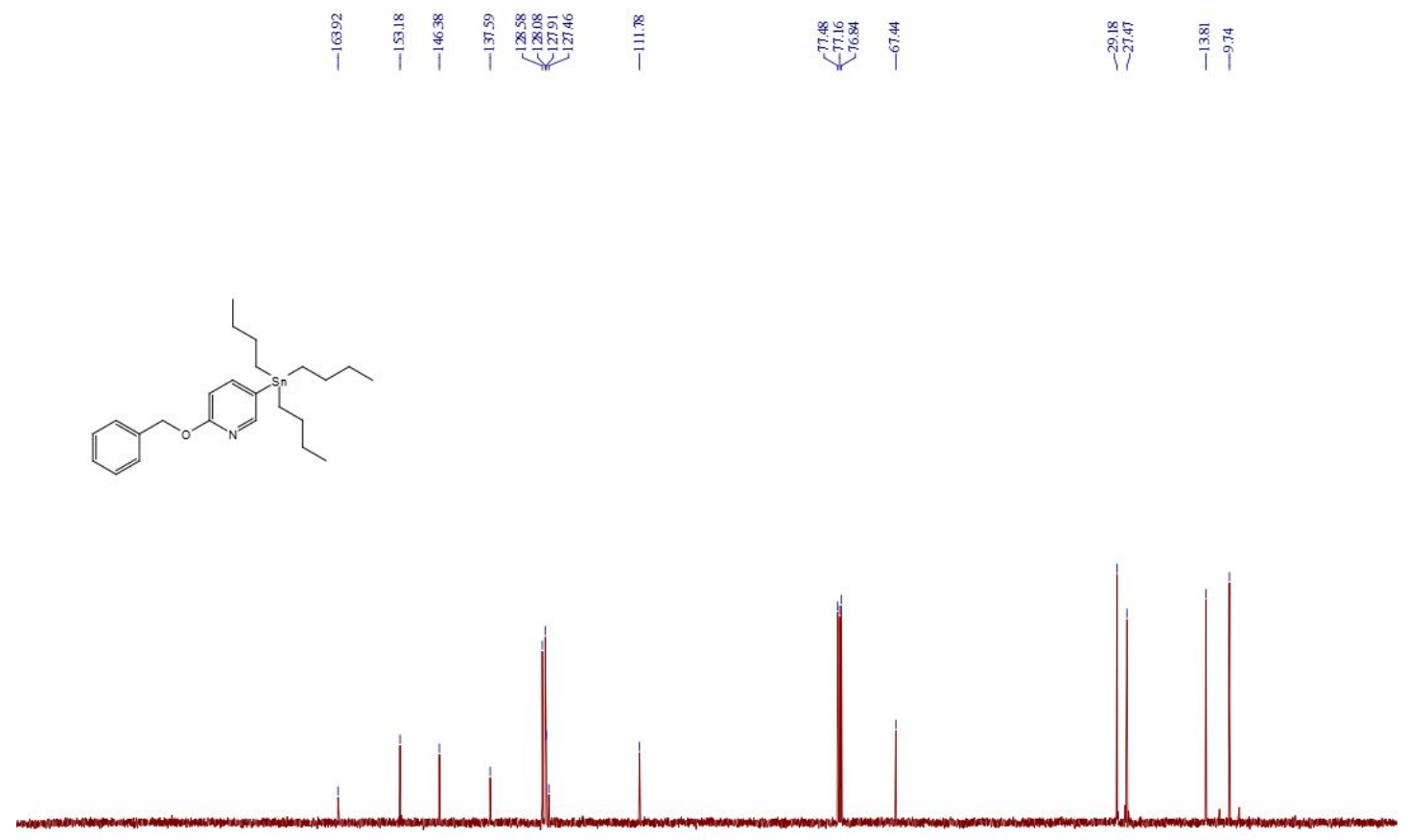

$\begin{array}{llllllllllll}210 & 200 & 190 & 180 & 170 & 160 & 150 & 140 & 130 & 120 & 110 & 100 \\ \mathrm{fl}(\mathrm{ppm}) & 90\end{array}$

${ }^{1} \mathrm{H}\left(400 \mathrm{MHz}, \mathrm{CDCl}_{3}\right)$ of $\mathbf{1 y}$

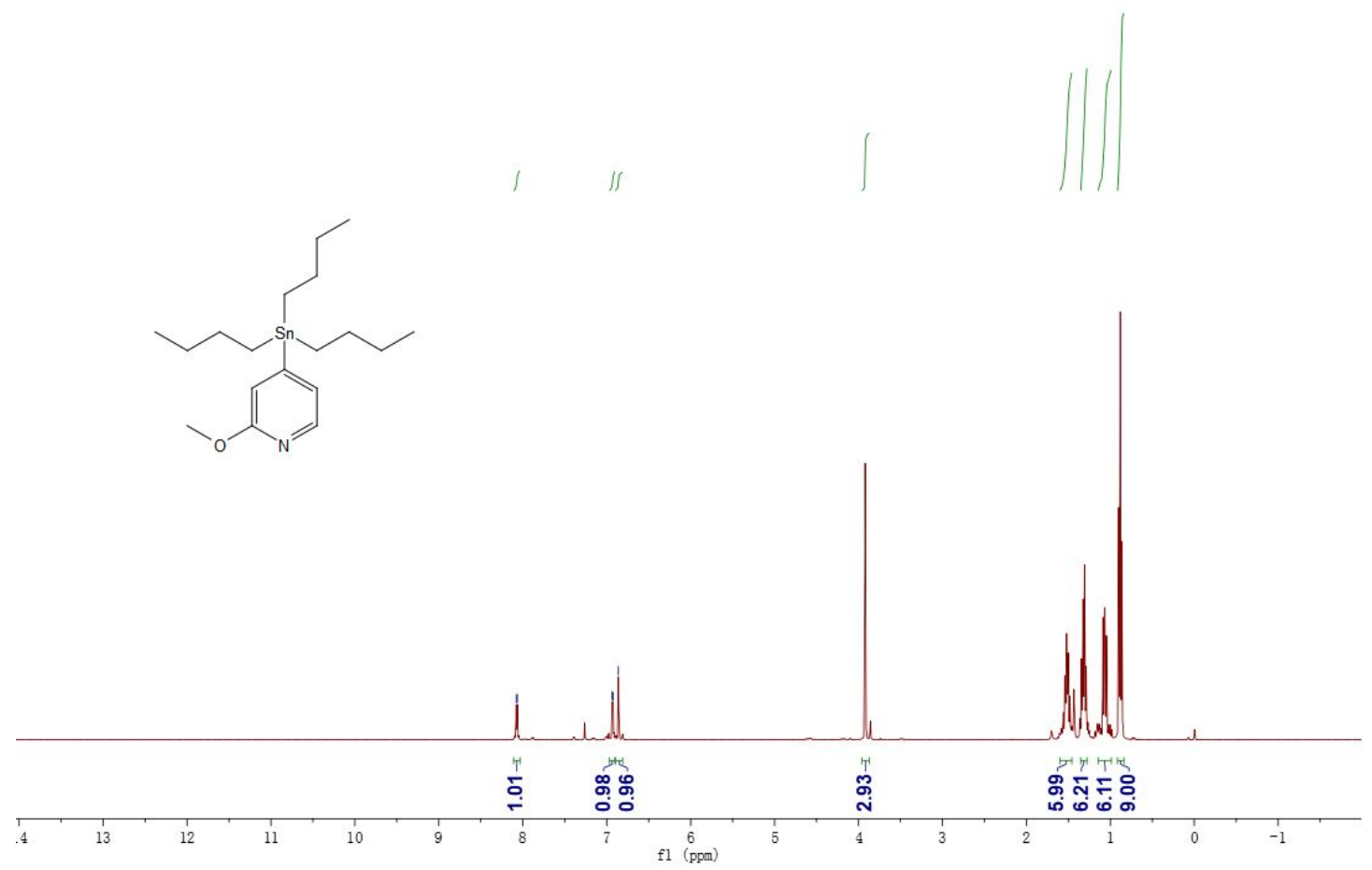


${ }^{13} \mathrm{C}\left\{{ }^{1} \mathrm{H}\right\}\left(101 \mathrm{MHz}, \mathrm{CDCl}_{3}\right)$ of $\mathbf{1 y}$

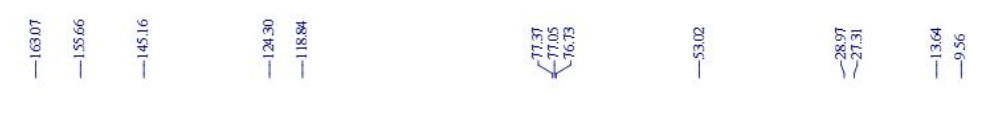
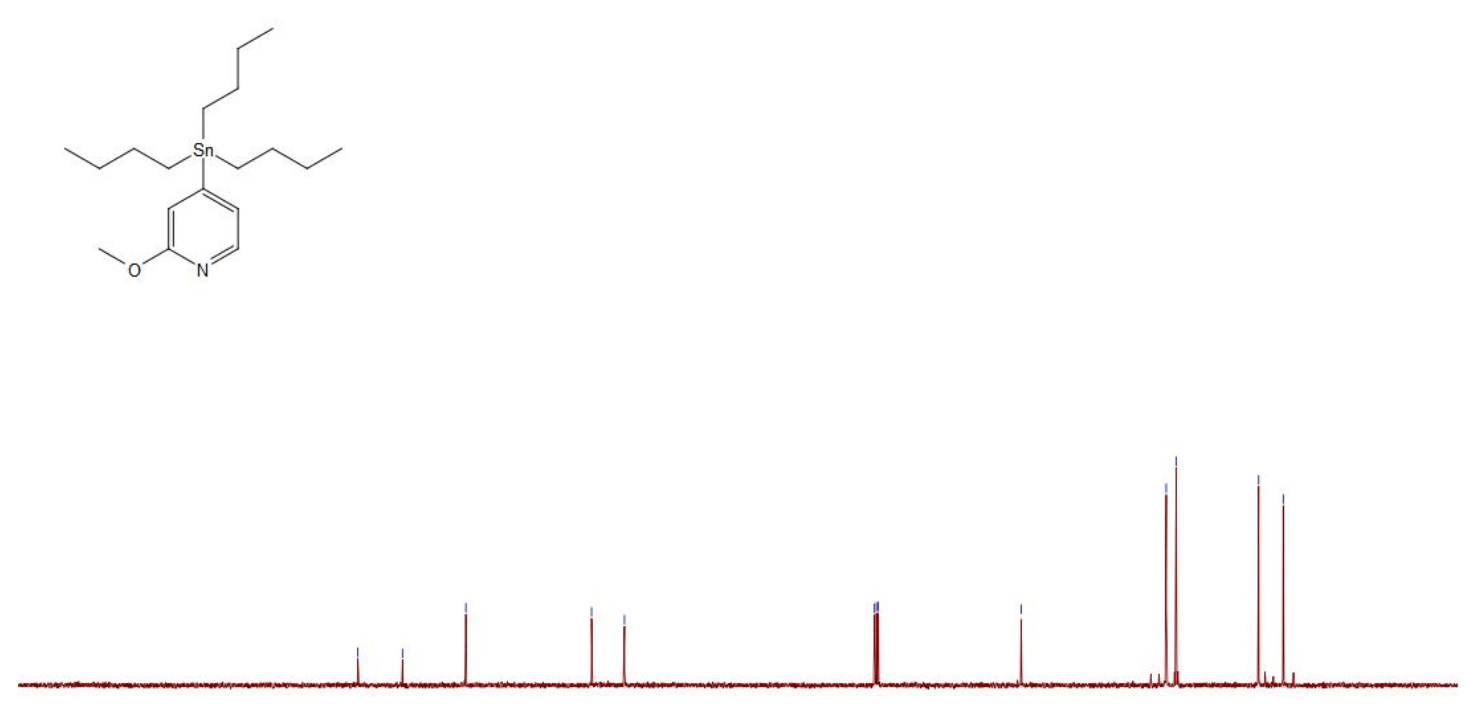

${ }^{1} \mathrm{H}\left(400 \mathrm{MHz}, \mathrm{CDCl}_{3}\right)$ of $\mathbf{2} \mathbf{b}$

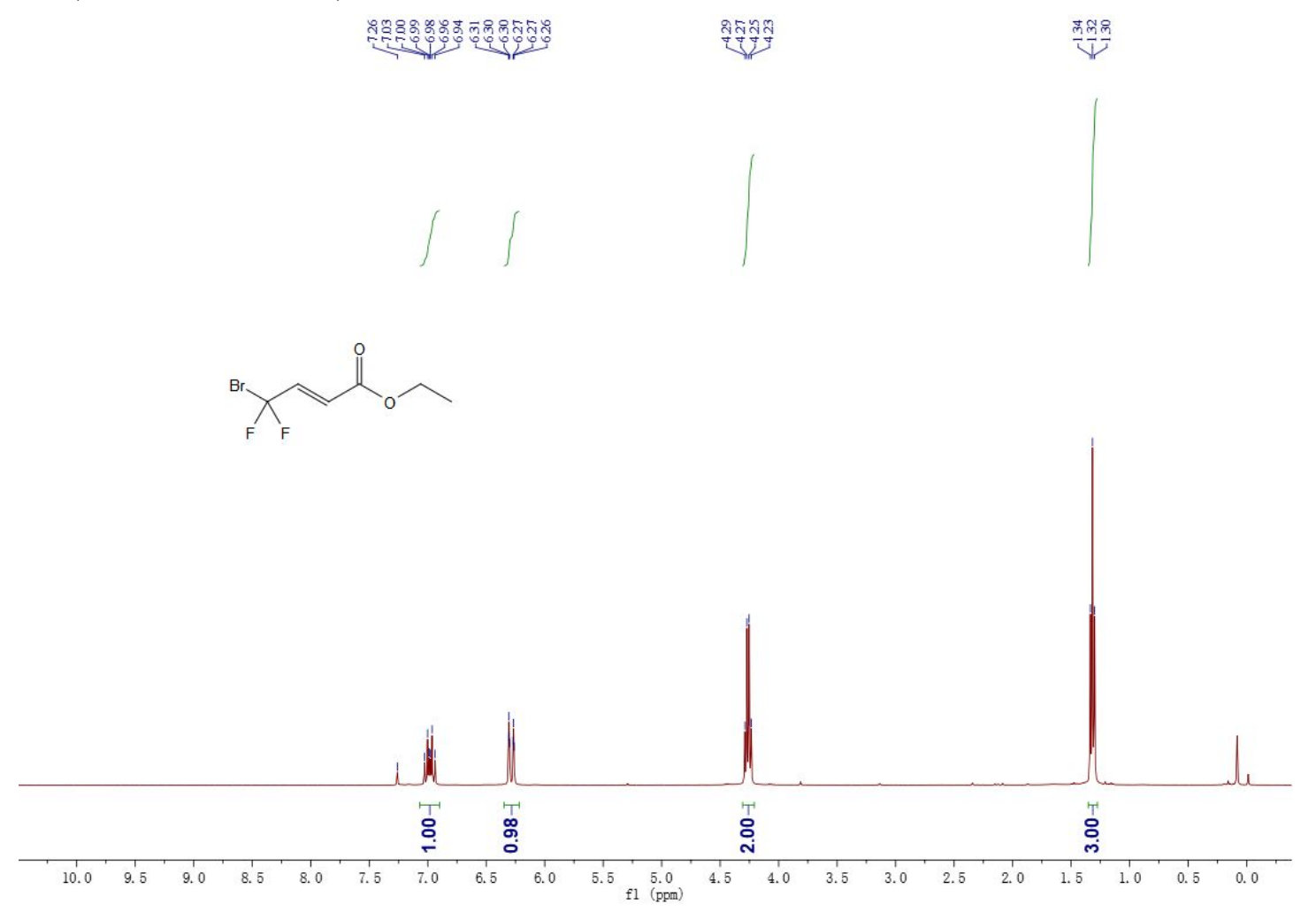


${ }^{19} \mathrm{~F}\left(376 \mathrm{MHz}, \mathrm{CDCl}_{3}\right)$ of $\mathbf{2 b}$

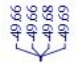<smiles>CCOC(=O)/C=C/C(F)(F)I</smiles>

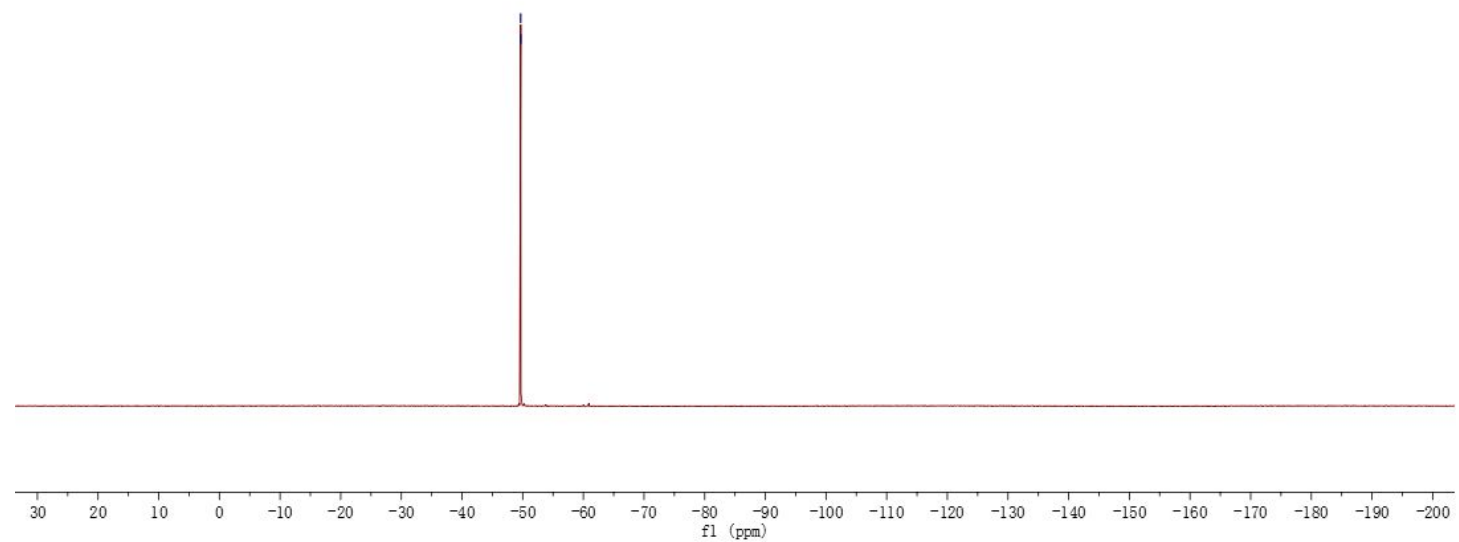

${ }^{13} \mathrm{C}\left\{{ }^{1} \mathrm{H}\right\}\left(101 \mathrm{MHz}, \mathrm{CDCl}_{3}\right)$ of $\mathbf{2} \mathbf{b}$<smiles>[3H]C([B])(F)C=CC(=O)OCC</smiles>

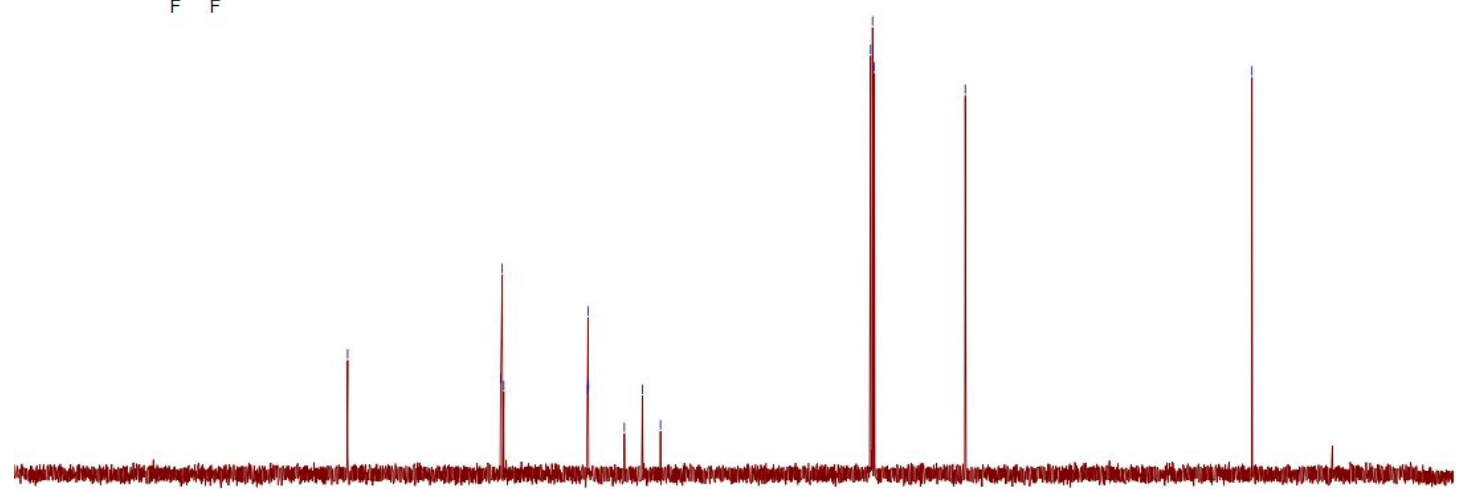

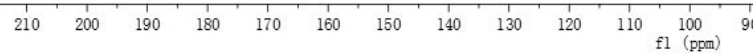


${ }^{1} \mathrm{H}\left(400 \mathrm{MHz}, \mathrm{CDCl}_{3}\right)$ of $\mathbf{2 c}$

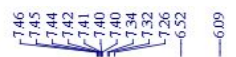
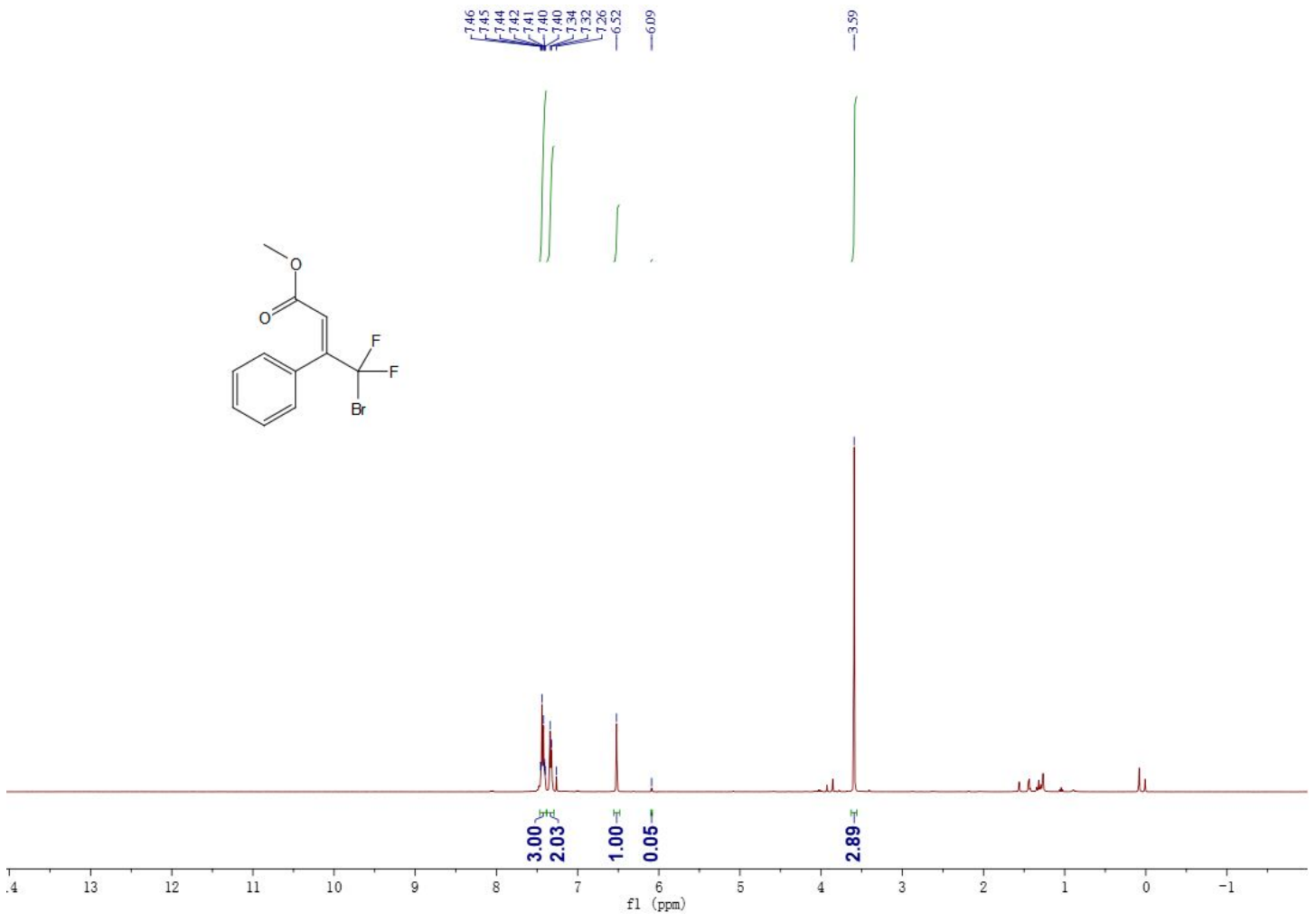

${ }^{19} \mathrm{~F}\left(376 \mathrm{MHz}, \mathrm{CDCl}_{3}\right)$ of $\mathbf{2 c}$

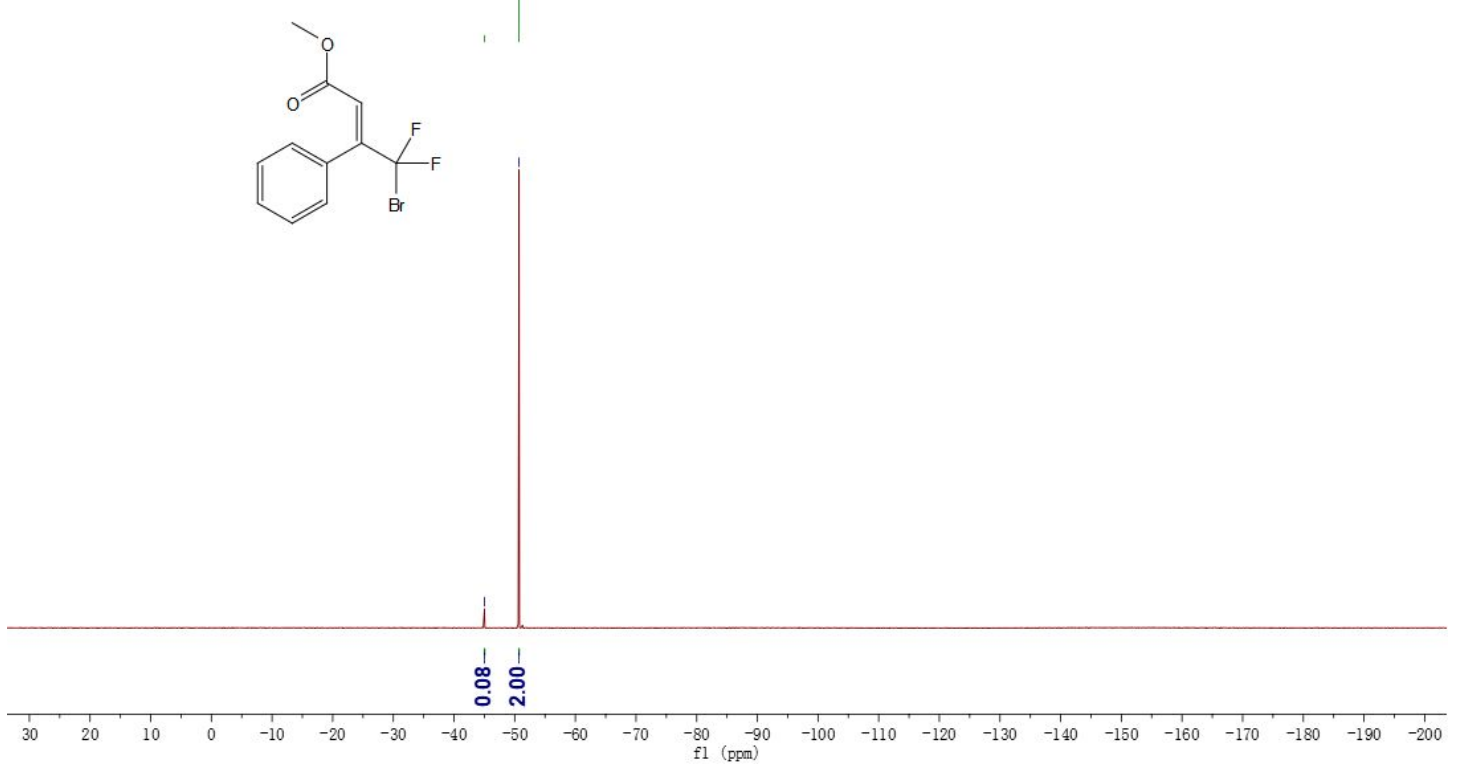

S21 
${ }^{13} \mathrm{C}\left\{{ }^{1} \mathrm{H}\right\}\left(101 \mathrm{MHz}, \mathrm{CDCl}_{3}\right)$ of $\mathbf{2 c}$

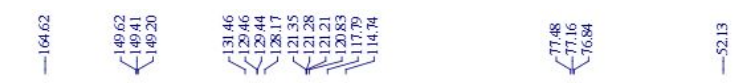

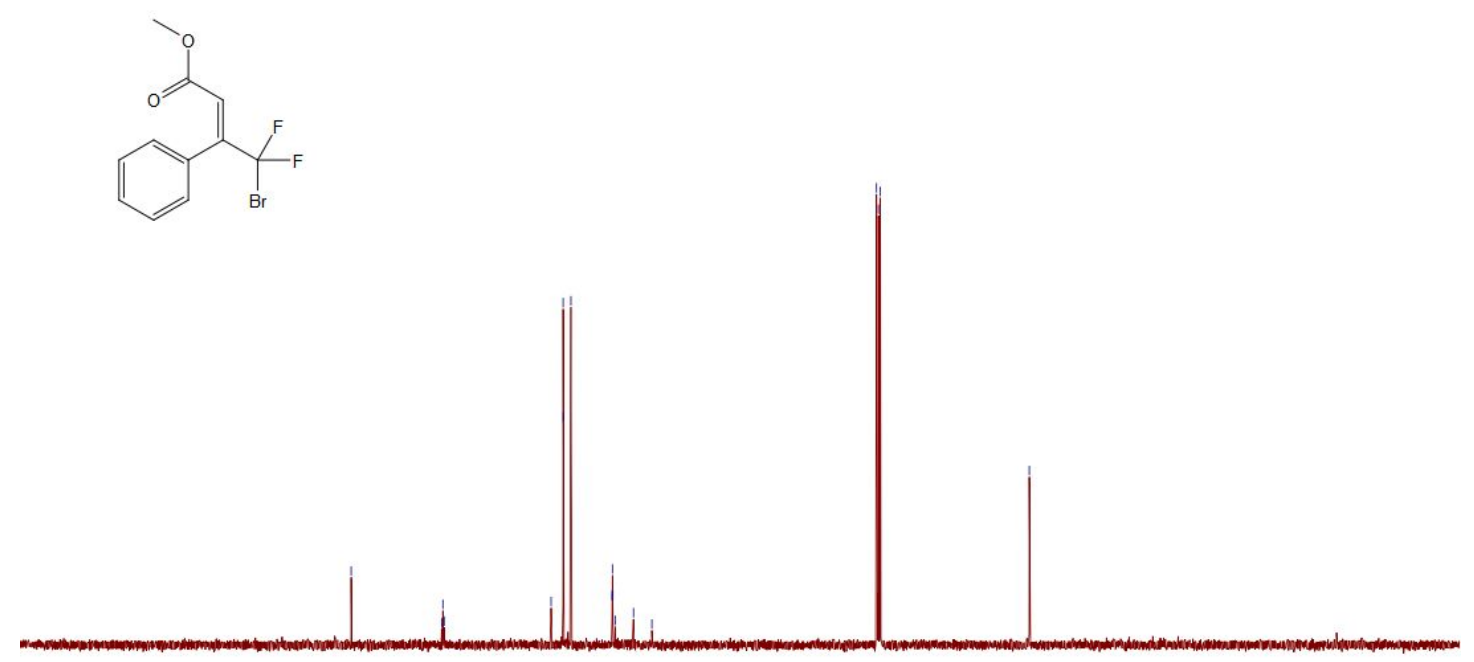

${ }^{1} \mathrm{H}\left(400 \mathrm{MHz}, \mathrm{CDCl}_{3}\right)$ of $\mathbf{2 d}$

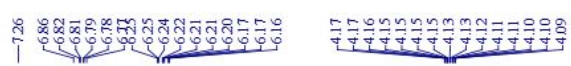

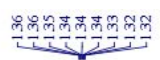
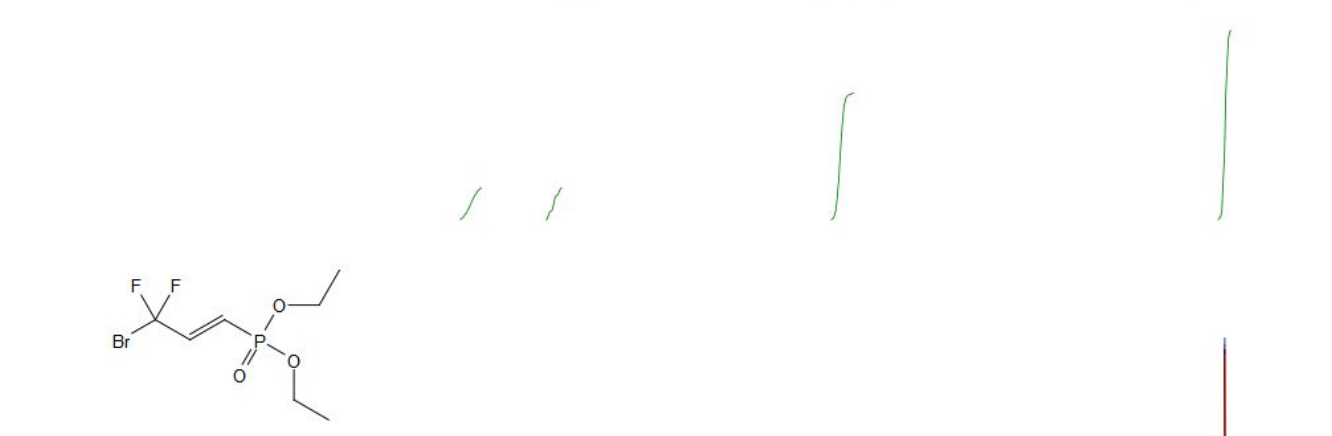

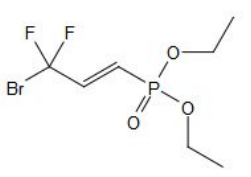

fl $(\mathrm{ppm})$ 
${ }^{19} \mathrm{~F}\left(376 \mathrm{MHz}, \mathrm{CDCl}_{3}\right)$ of $\mathbf{2 d}$

जo
$0 \%$
Y

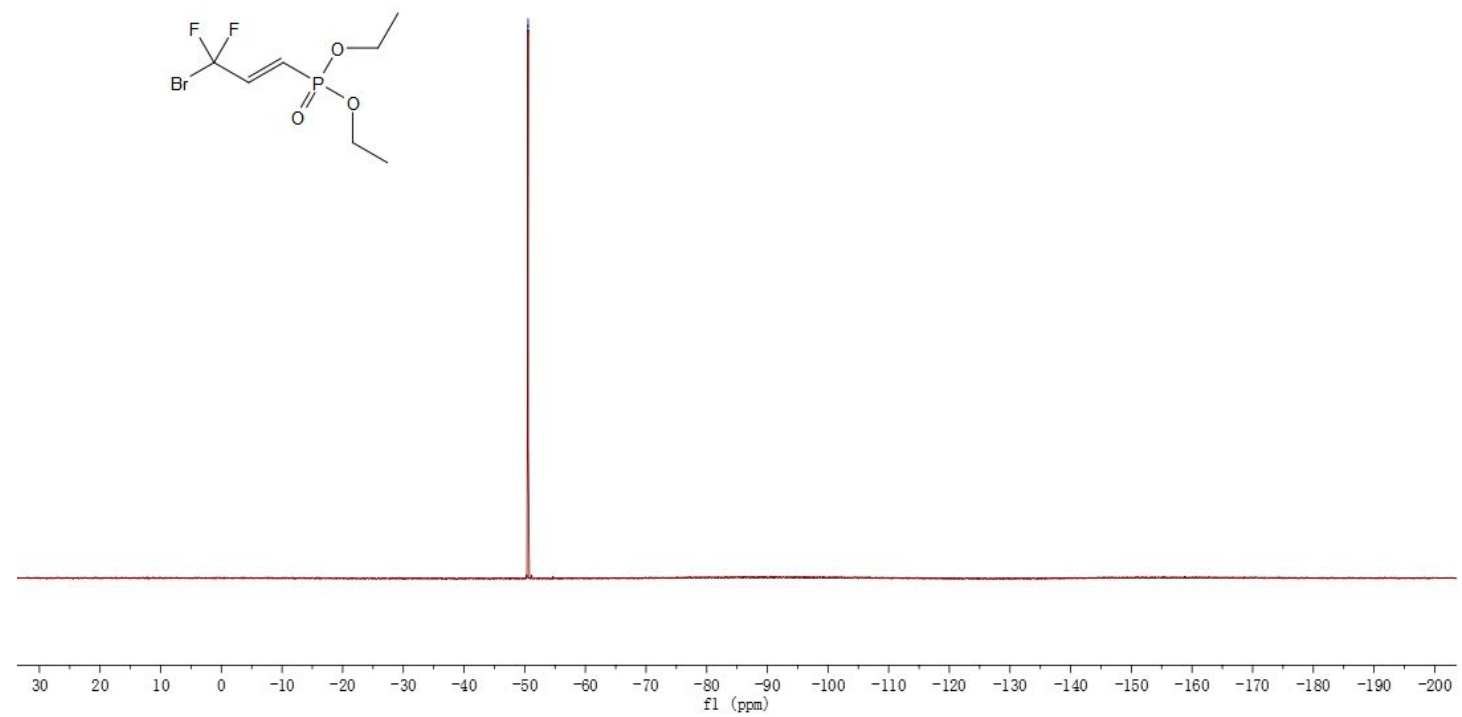

${ }^{13} \mathrm{C}\left\{{ }^{1} \mathrm{H}\right\}\left(101 \mathrm{MHz}, \mathrm{CDCl}_{3}\right)$ of $\mathbf{2 d}$
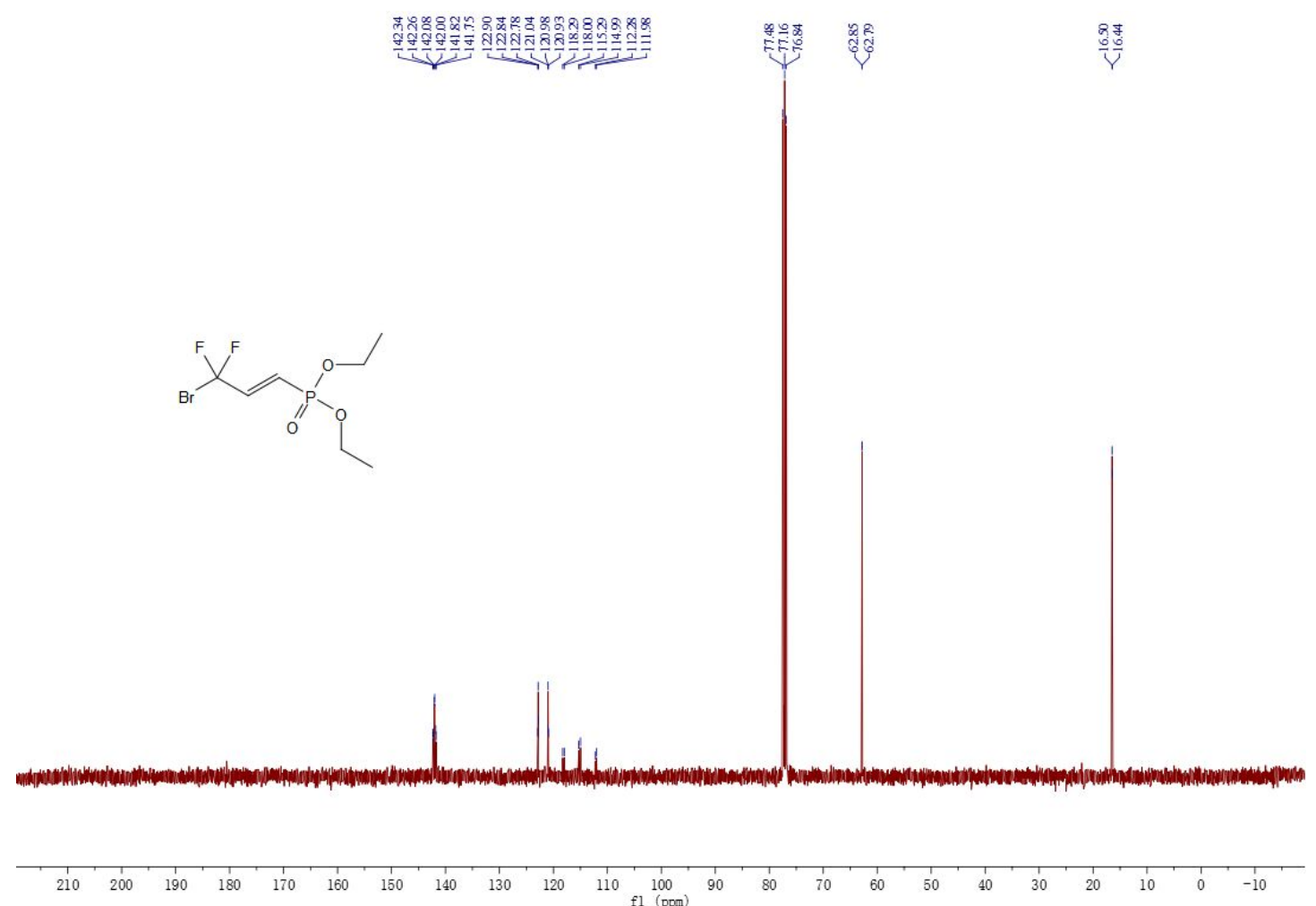
${ }^{31} \mathrm{P}\left\{{ }^{1} \mathrm{H}\right\} \mathrm{NMR}\left(162 \mathrm{MHz}, \mathrm{CDCl}_{3}\right)$ of $\mathbf{2 d}$

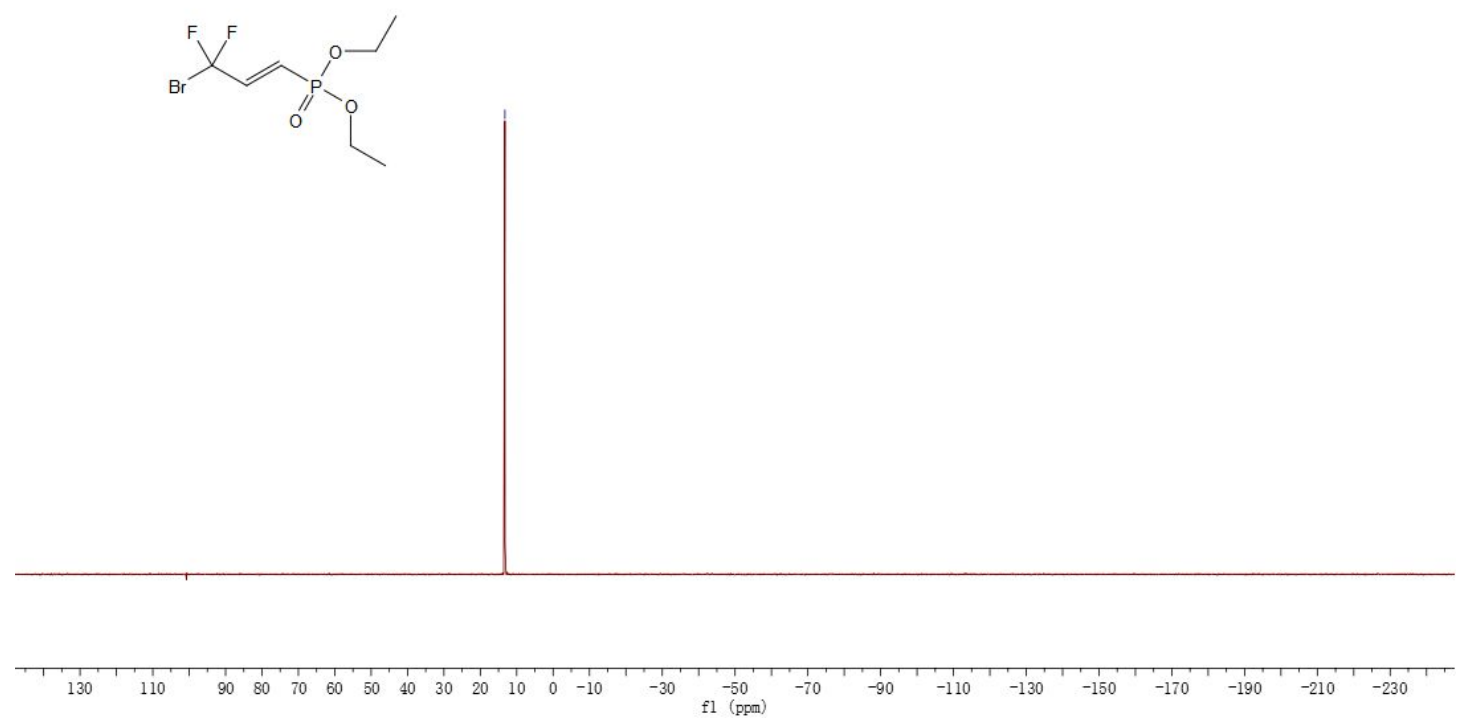

${ }^{1} \mathrm{H}\left(400 \mathrm{MHz}, \mathrm{CDCl}_{3}\right)$ of $\mathbf{2 e}$

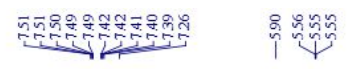
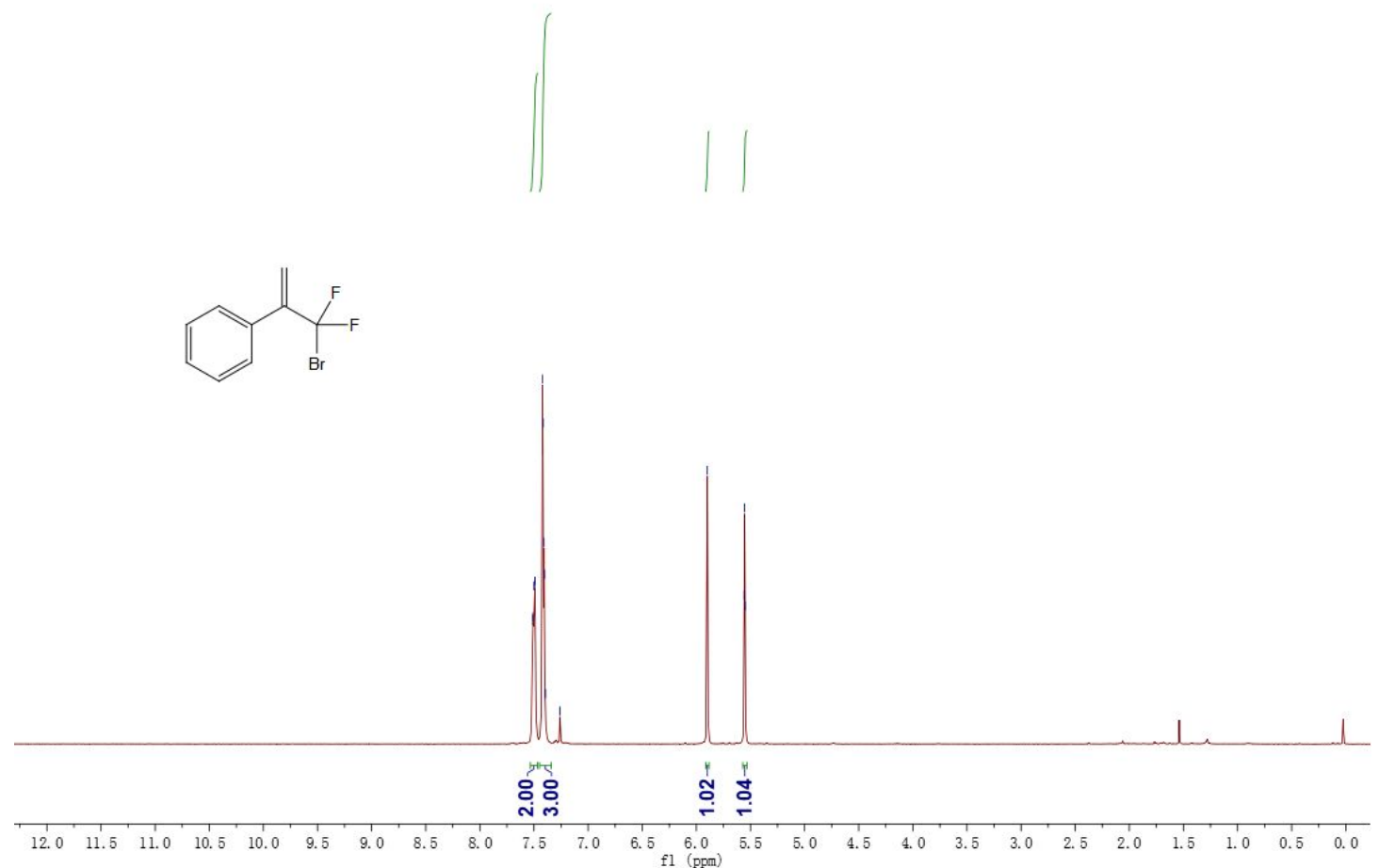
${ }^{19} \mathrm{~F}\left(376 \mathrm{MHz}, \mathrm{CDCl}_{3}\right)$ of $\mathbf{2 e}$

\section{$\frac{m}{a+⿱ 亠 䒑 十}$}

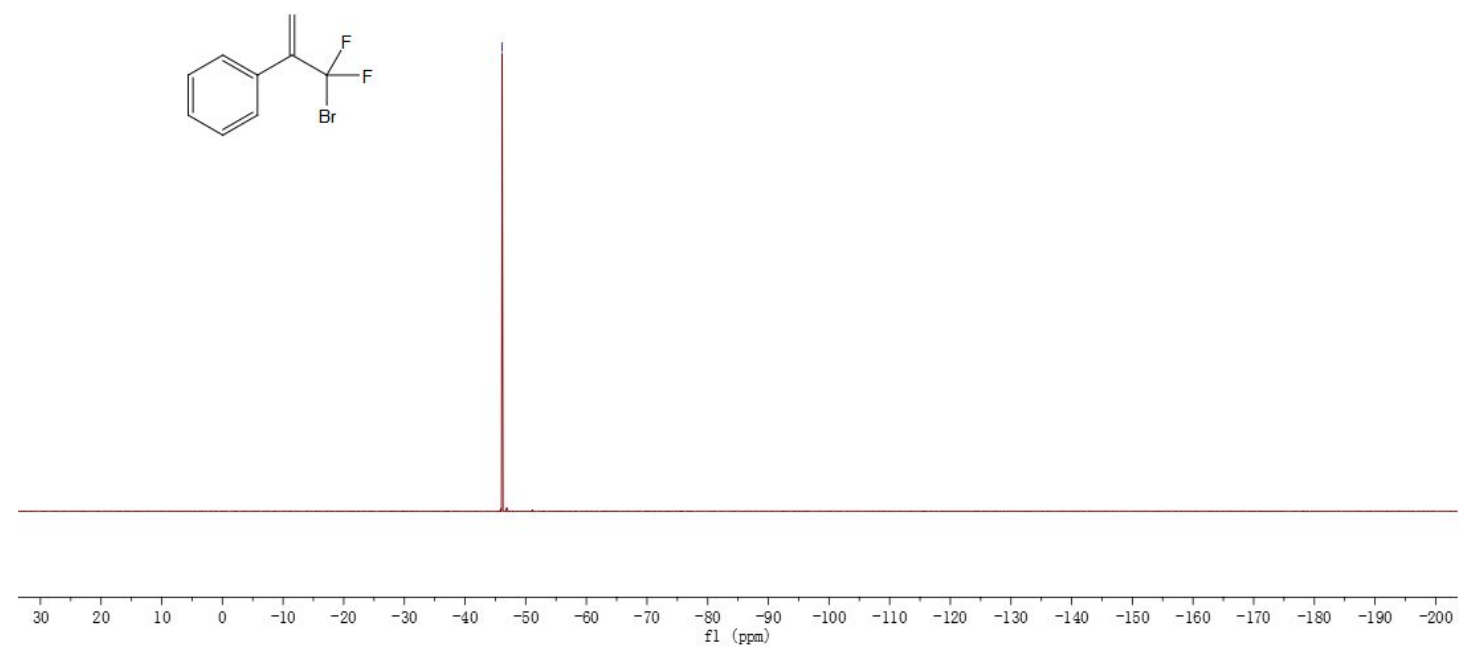

${ }^{13} \mathrm{C}\left\{{ }^{1} \mathrm{H}\right\}\left(101 \mathrm{MHz}, \mathrm{CDCl}_{3}\right)$ of $\mathbf{2 e}$
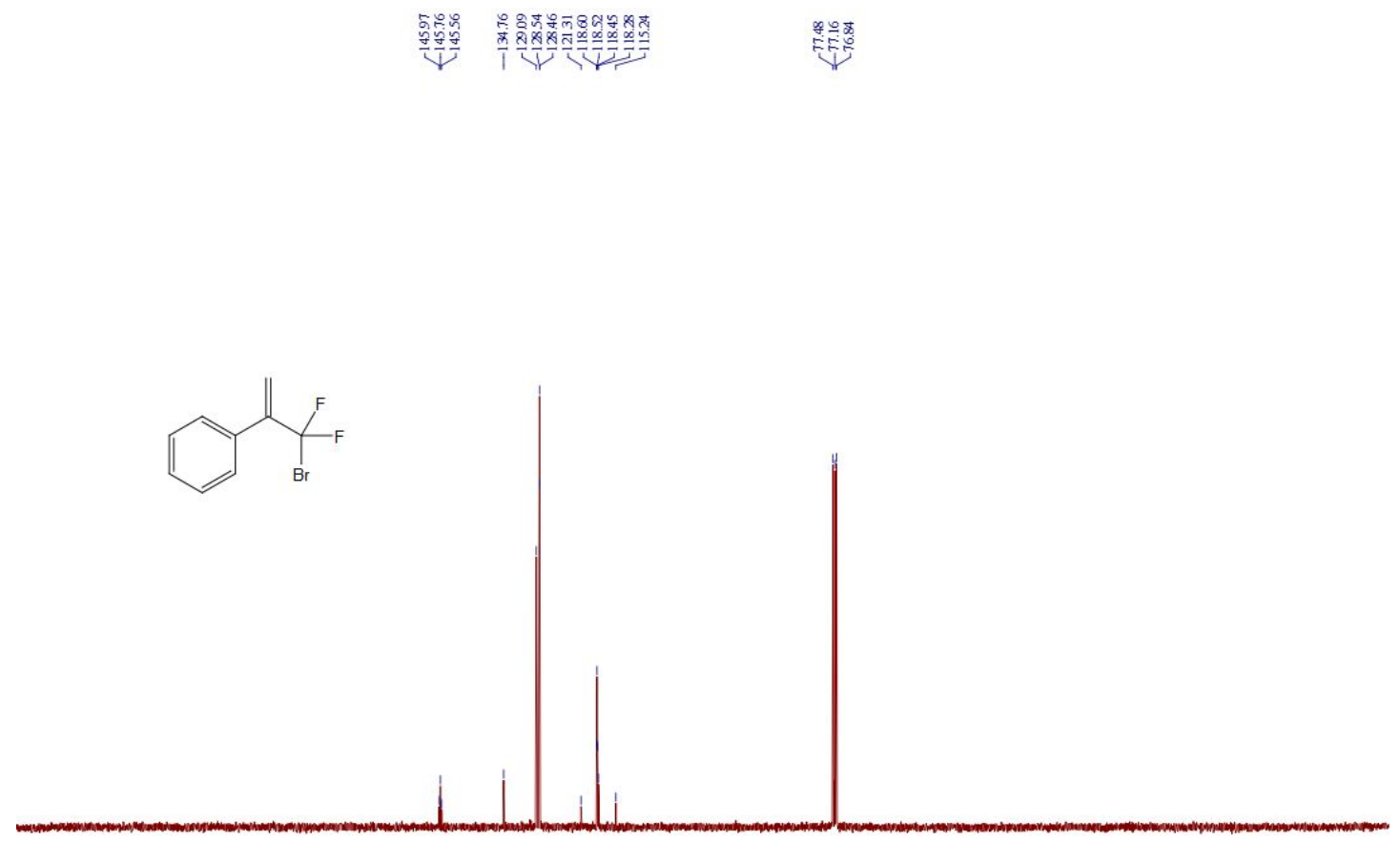
${ }^{1} \mathrm{H}\left(400 \mathrm{MHz}, \mathrm{CDCl}_{3}\right)$ of $\mathbf{7 f}$

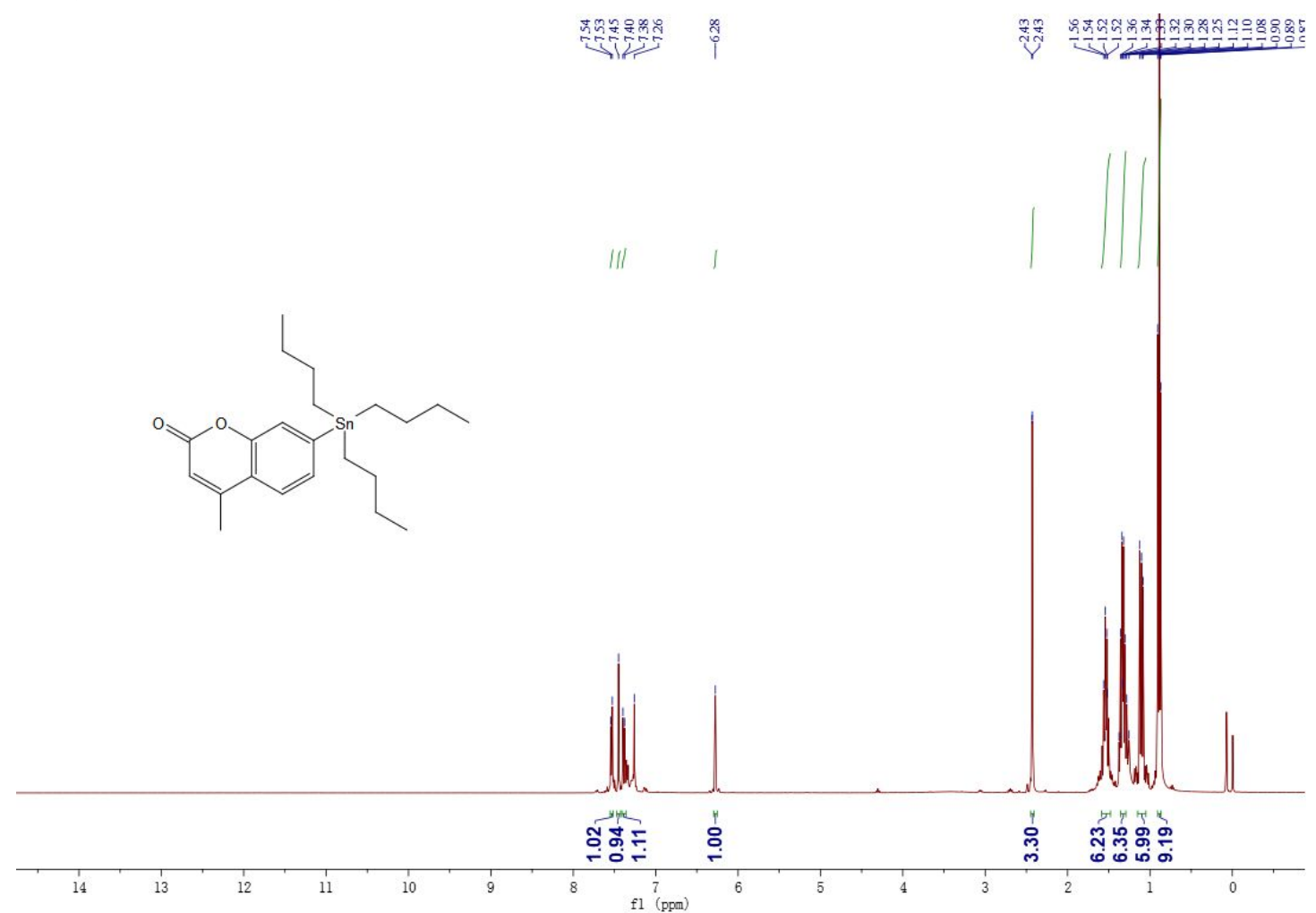

${ }^{13} \mathrm{C}\left\{{ }^{1} \mathrm{H}\right\}\left(101 \mathrm{MHz}, \mathrm{CDCl}_{3}\right)$ of $\mathbf{7 f}$

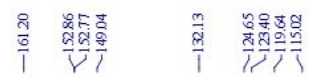

竞先
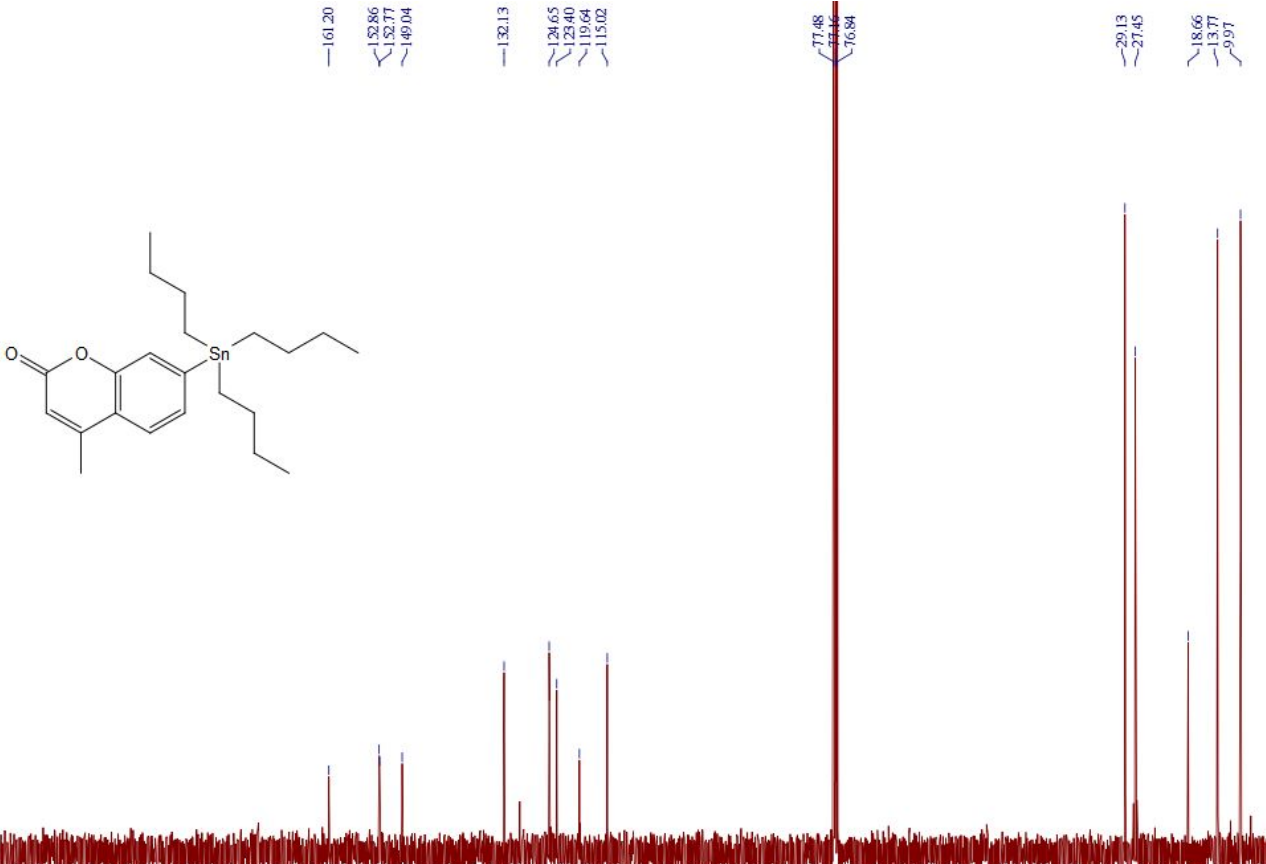

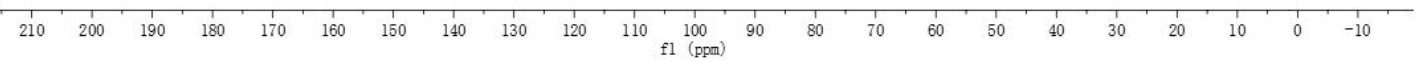


${ }^{1} \mathrm{H}\left(400 \mathrm{MHz}, \mathrm{CDCl}_{3}\right)$ of $\mathbf{3 a}$

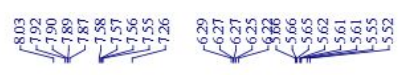
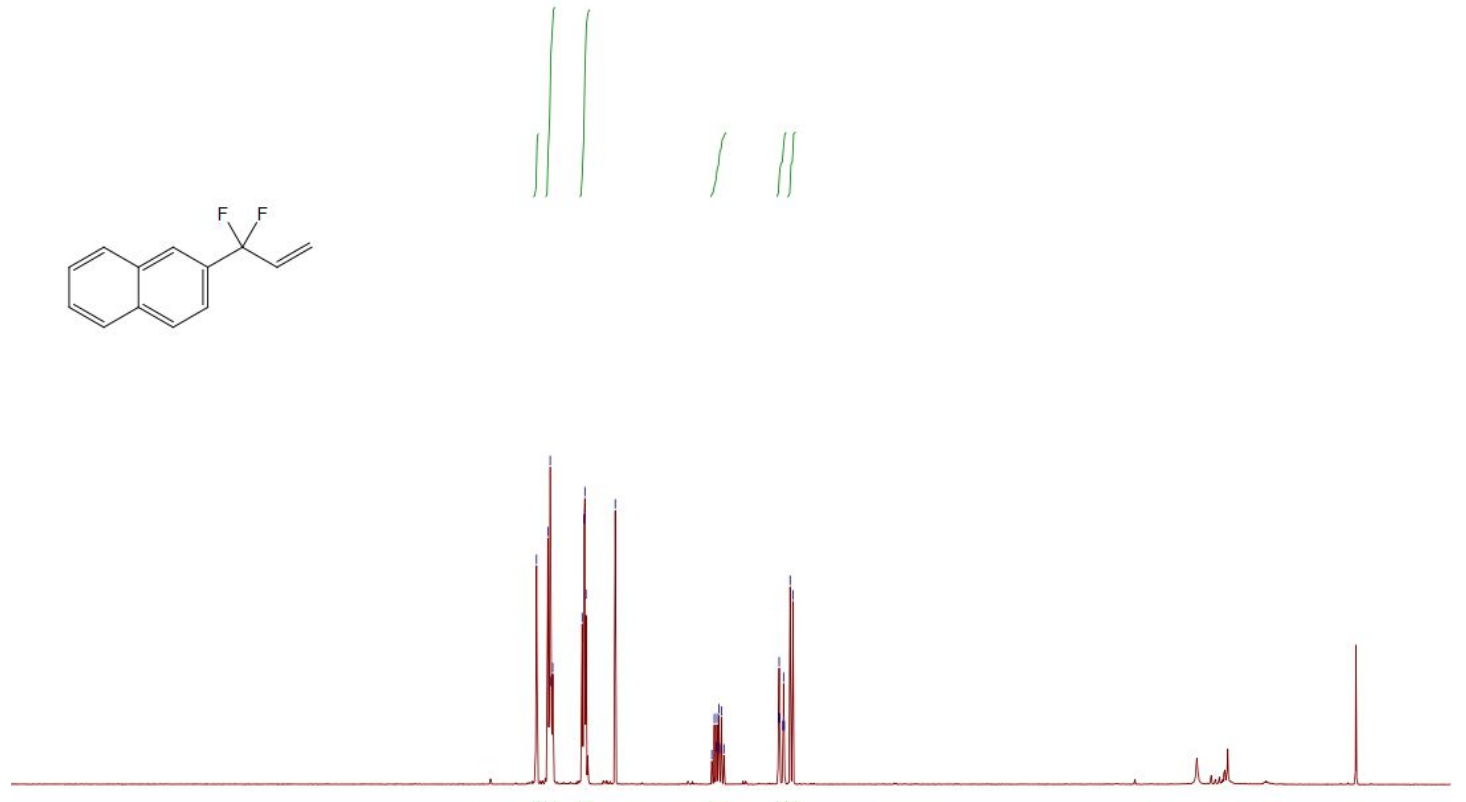

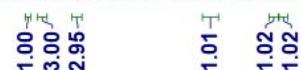

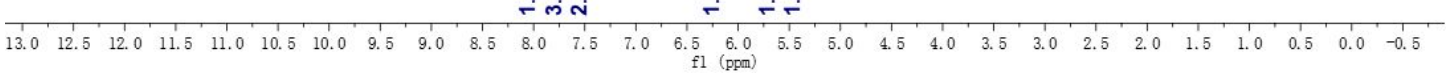

${ }^{19} \mathrm{~F}\left(176 \mathrm{MHz}, \mathrm{CDCl}_{3}\right)$ of $\mathbf{3 a}$

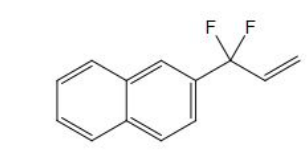

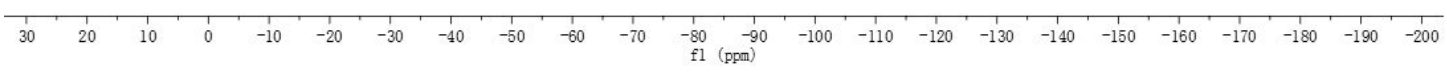

S27 
${ }^{13} \mathrm{C}\left\{{ }^{1} \mathrm{H}\right\}\left(101 \mathrm{MHz}, \mathrm{CDCl}_{3}\right)$ of $3 \mathrm{a}$

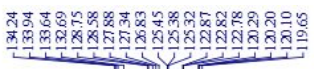
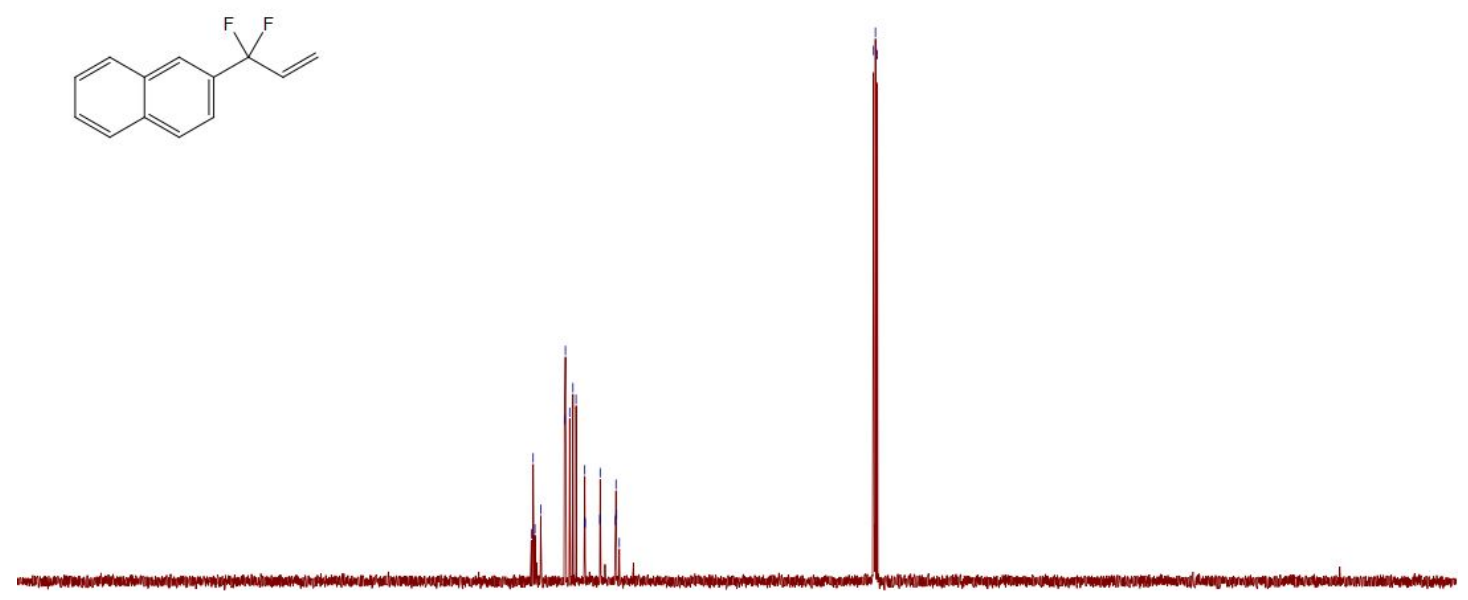

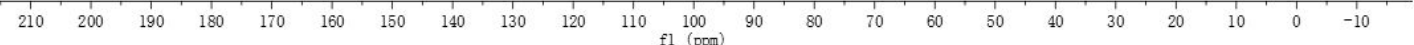

${ }^{1} \mathrm{H}\left(400 \mathrm{MHz}, \mathrm{CDCl}_{3}\right)$ of $\mathbf{4 a}$

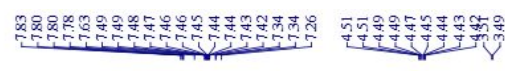

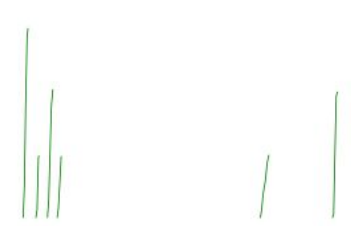

(1)

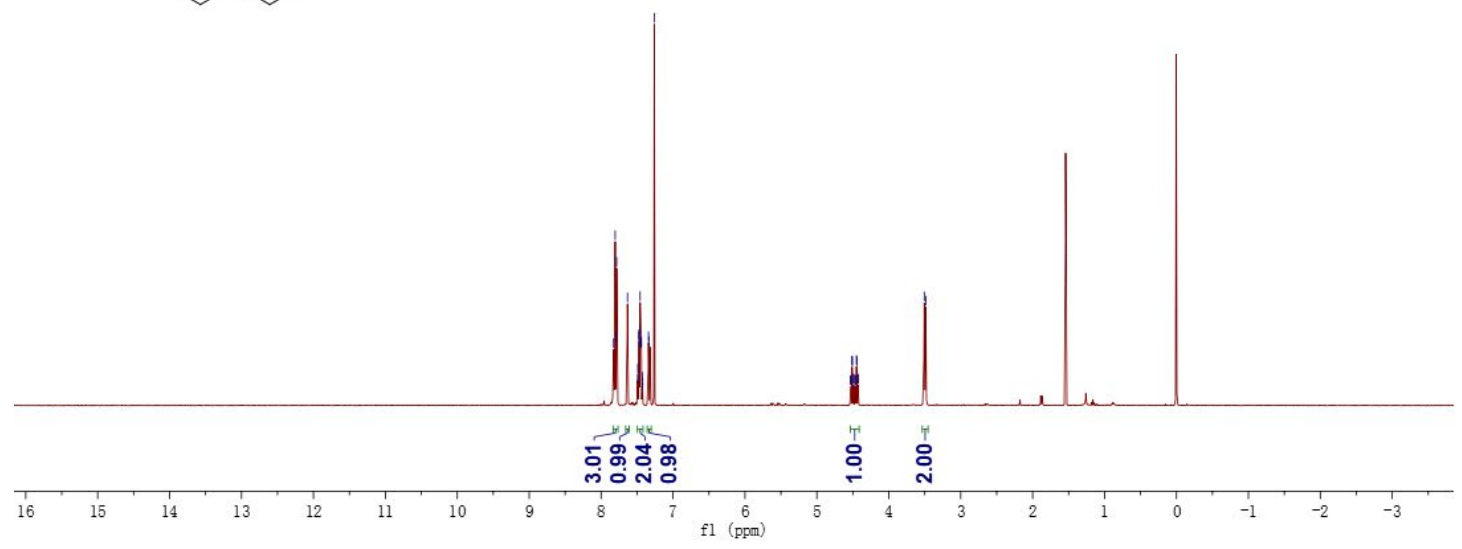


${ }^{19} \mathrm{~F}\left(377 \mathrm{MHz}, \mathrm{CDCl}_{3}\right)$ of $\mathbf{4 a}$
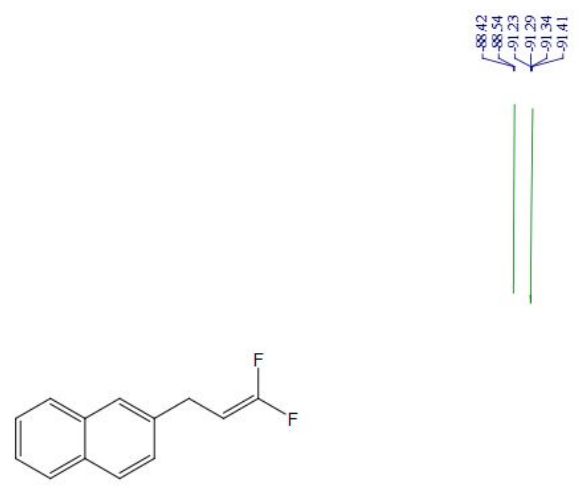

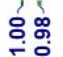

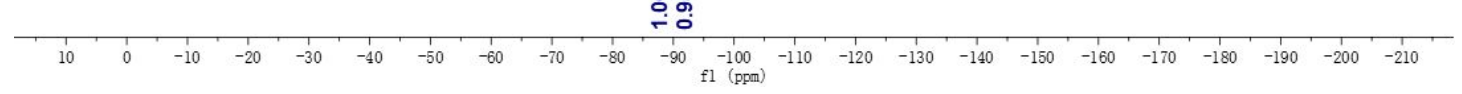

${ }^{13} \mathrm{C}\left\{{ }^{1} \mathrm{H}\right\}\left(176 \mathrm{MHz}, \mathrm{CDCl}_{3}\right)$ of $\mathbf{4 a}$

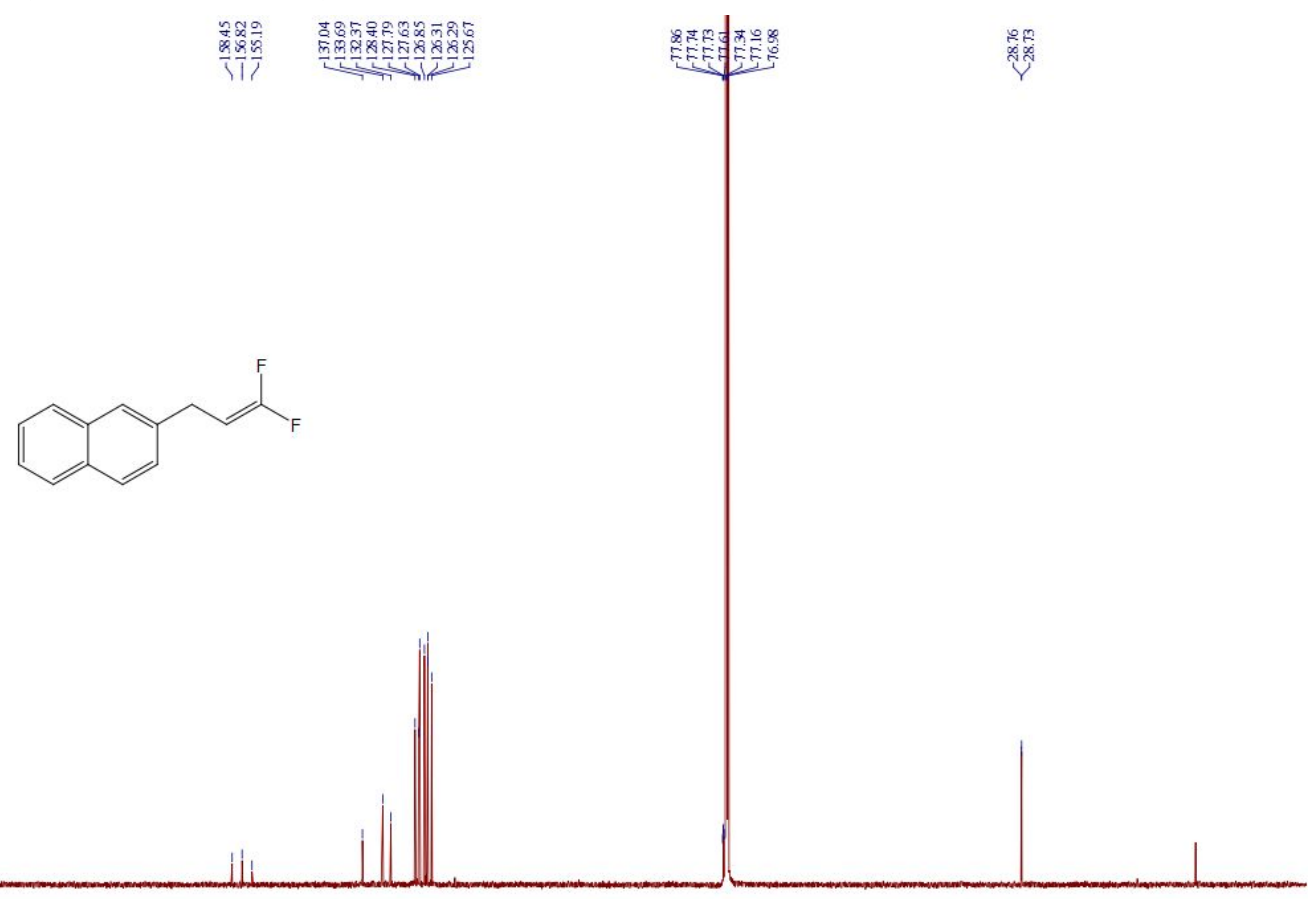

$\begin{array}{llllllllllllllllllllllllllllllllllll}1 & 1 & 200 & 190 & 180 & 170 & 160 & 150 & 140 & 130 & 120 & 110 & 100 & 90 & 80 & 70 & 60 & 50 & 40 & 30 & 20 & 10 & 0 & -10\end{array}$ 
${ }^{1} \mathrm{H}\left(400 \mathrm{MHz}, \mathrm{CDCl}_{3}\right)$ of $\mathbf{5 a}$

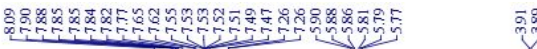

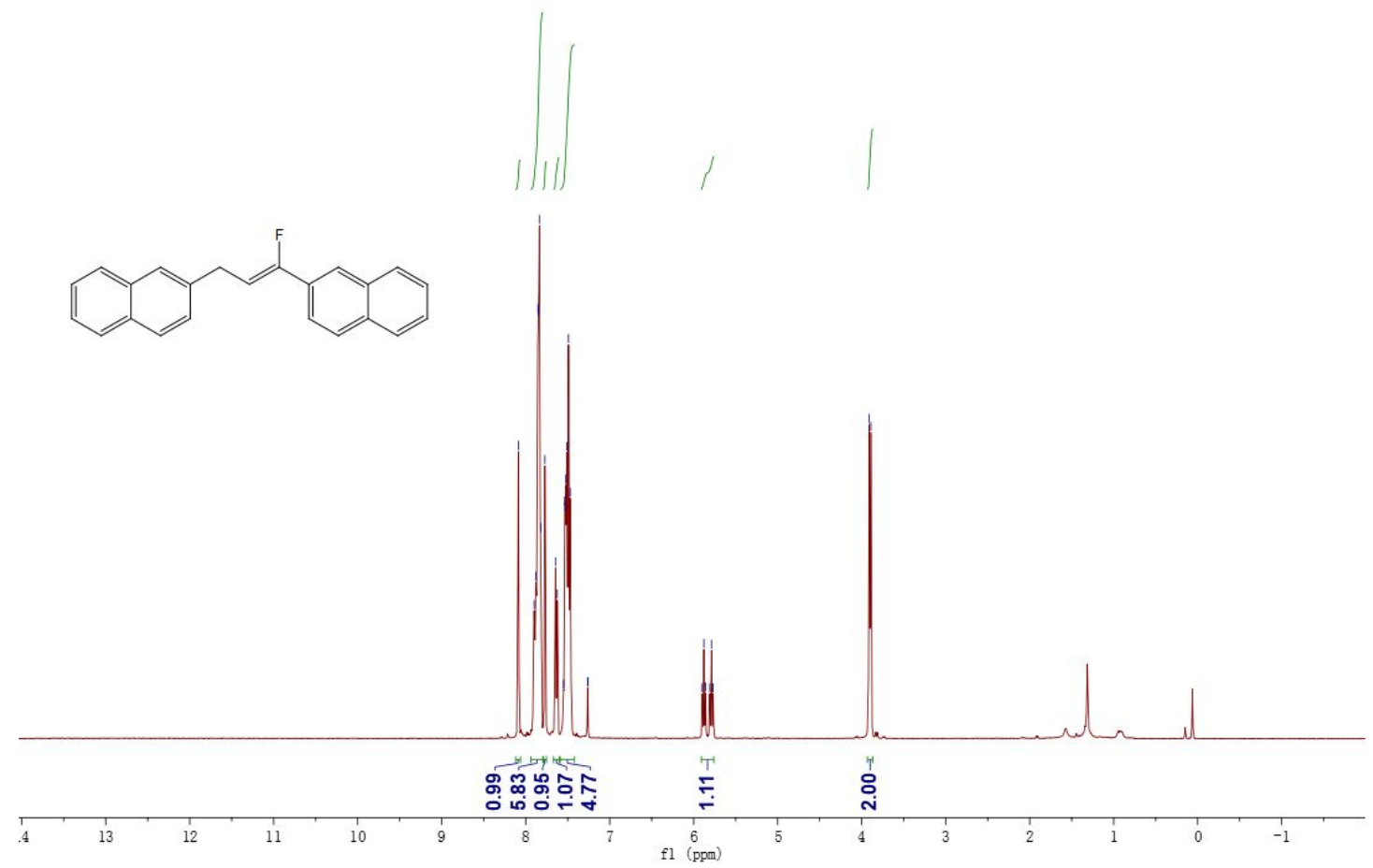

${ }^{19} \mathrm{~F}\left(176 \mathrm{MHz}, \mathrm{CDCl}_{3}\right)$ of $\mathbf{5 a}$

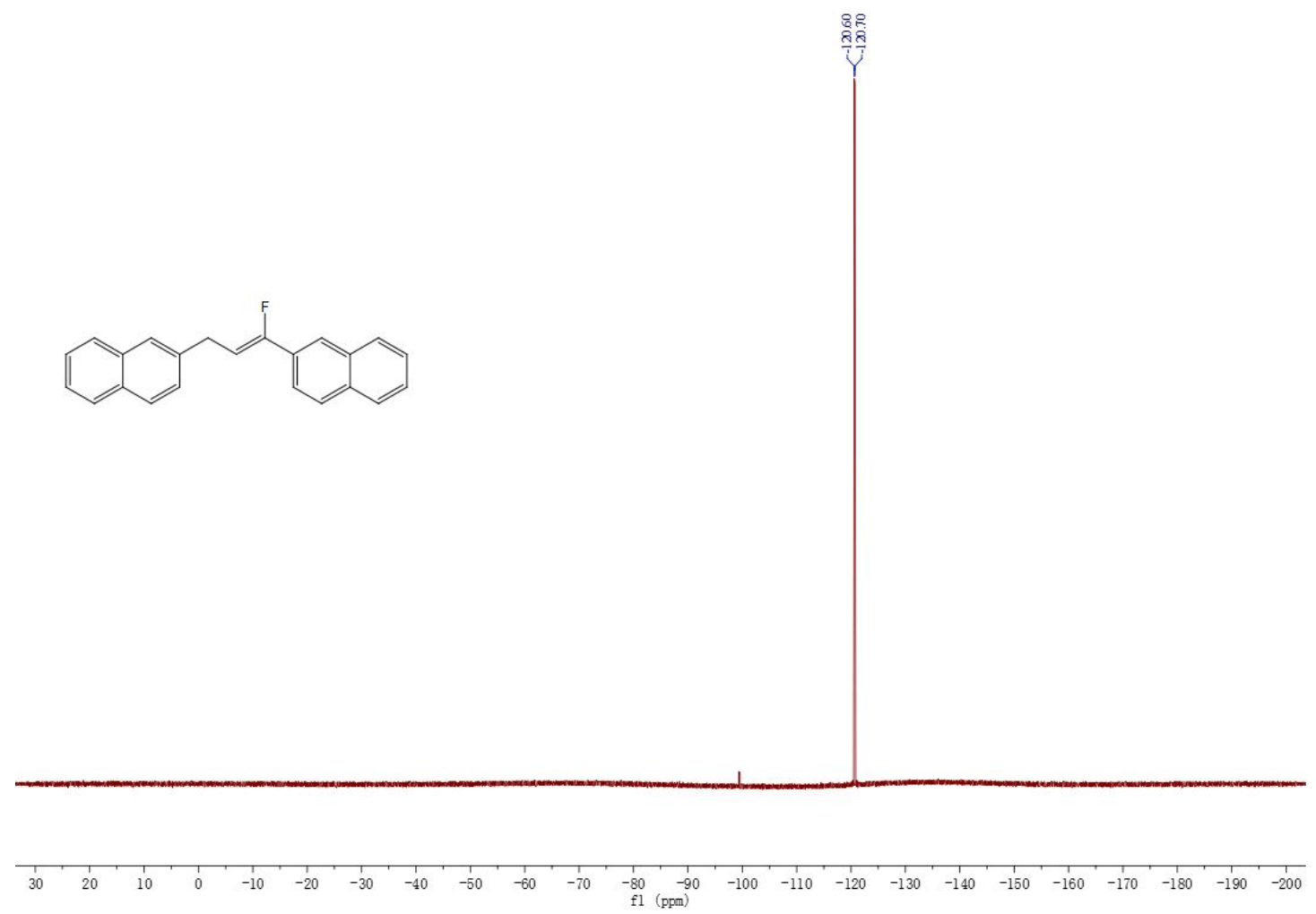


${ }^{13} \mathrm{C}\left\{{ }^{1} \mathrm{H}\right\}\left(101 \mathrm{MHz}, \mathrm{CDCl}_{3}\right)$ of $\mathbf{5 a}$

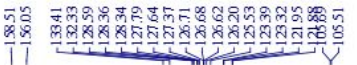

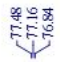

高脸
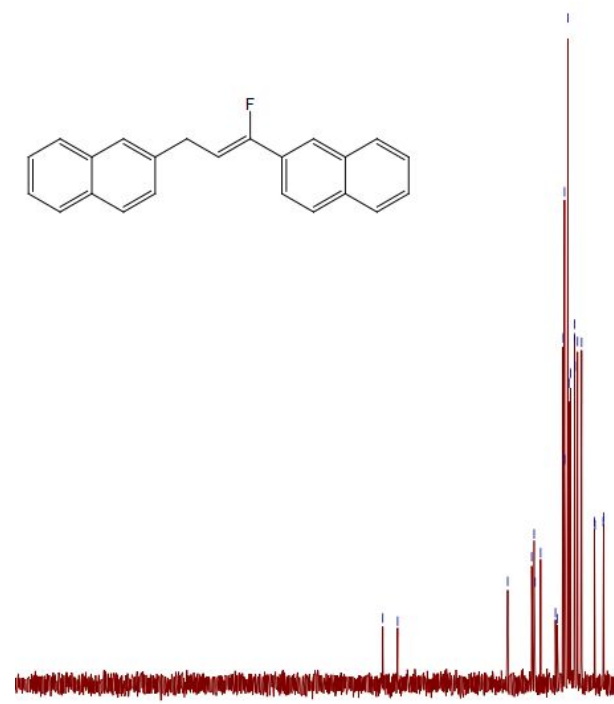

$\begin{array}{lllll}210 & 200 & 190 & 180 & 170\end{array}$

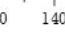

$110_{\mathrm{fl}} 100$

${ }^{1} \mathrm{H}\left(400 \mathrm{MHz}, \mathrm{CDCl}_{3}\right)$ of $\mathbf{3 b}$

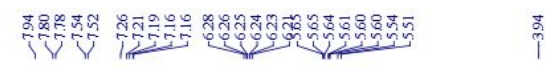
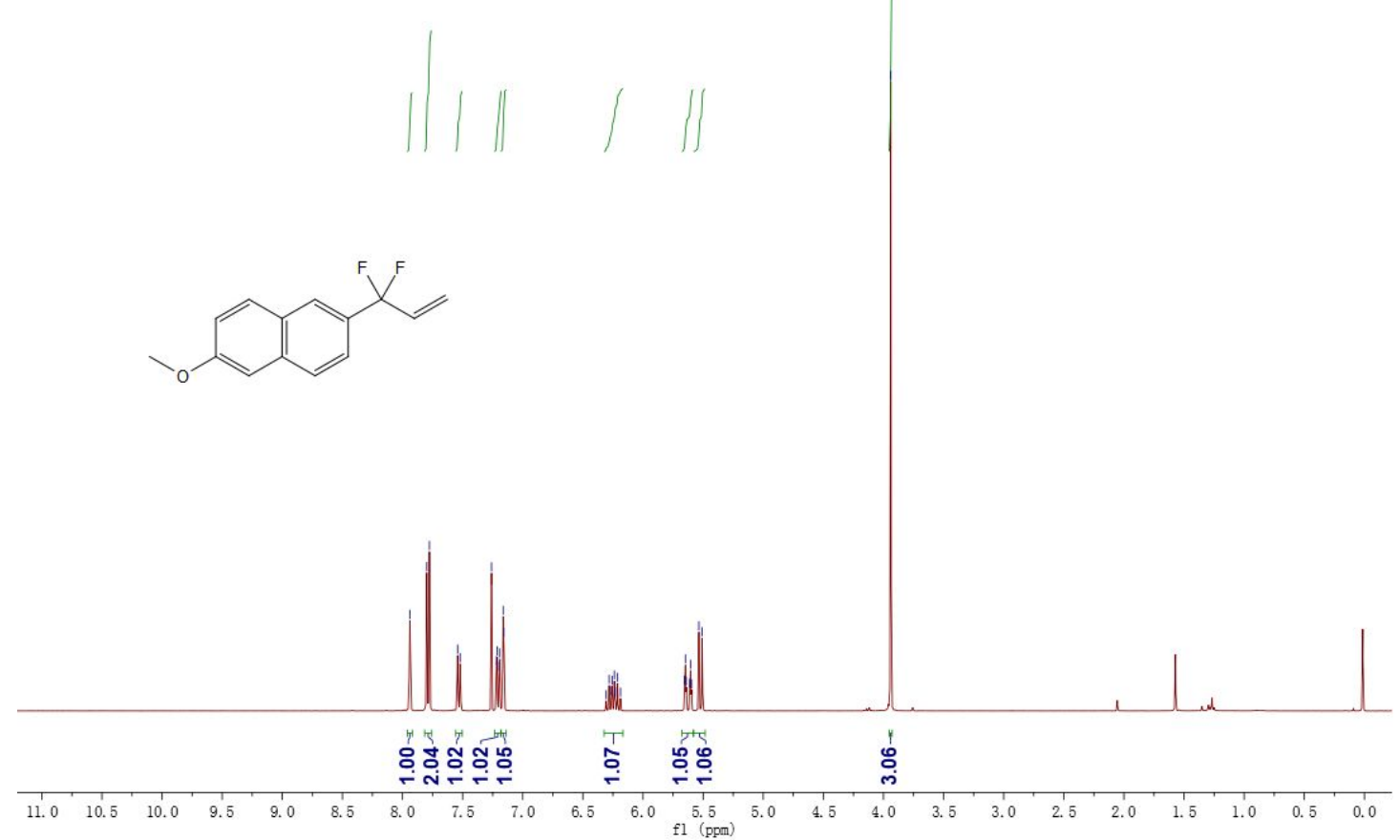
${ }^{19} \mathrm{~F}\left(376 \mathrm{MHz}, \mathrm{CDCl}_{3}\right)$ of $\mathbf{3 b}$
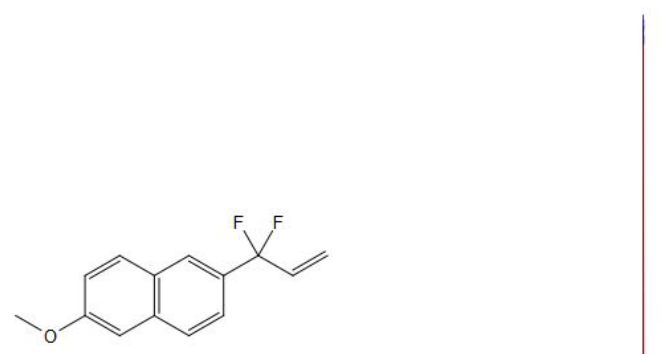

\begin{tabular}{llllllllllllllllllllllllll}
\hline & 1 & 1 & 10 & 0 & -10 & -20 & -30 & -40 & -50 & -60 & -70 & -80 & -90 & -100 & -110 & -120 & -130 & -140 & -150 & -160 & -170 & -180 & -190 & -200
\end{tabular}

${ }^{13} \mathrm{C}\left\{{ }^{1} \mathrm{H}\right\}\left(101 \mathrm{MHz}, \mathrm{CDCl}_{3}\right)$ of $\mathbf{3 b}$
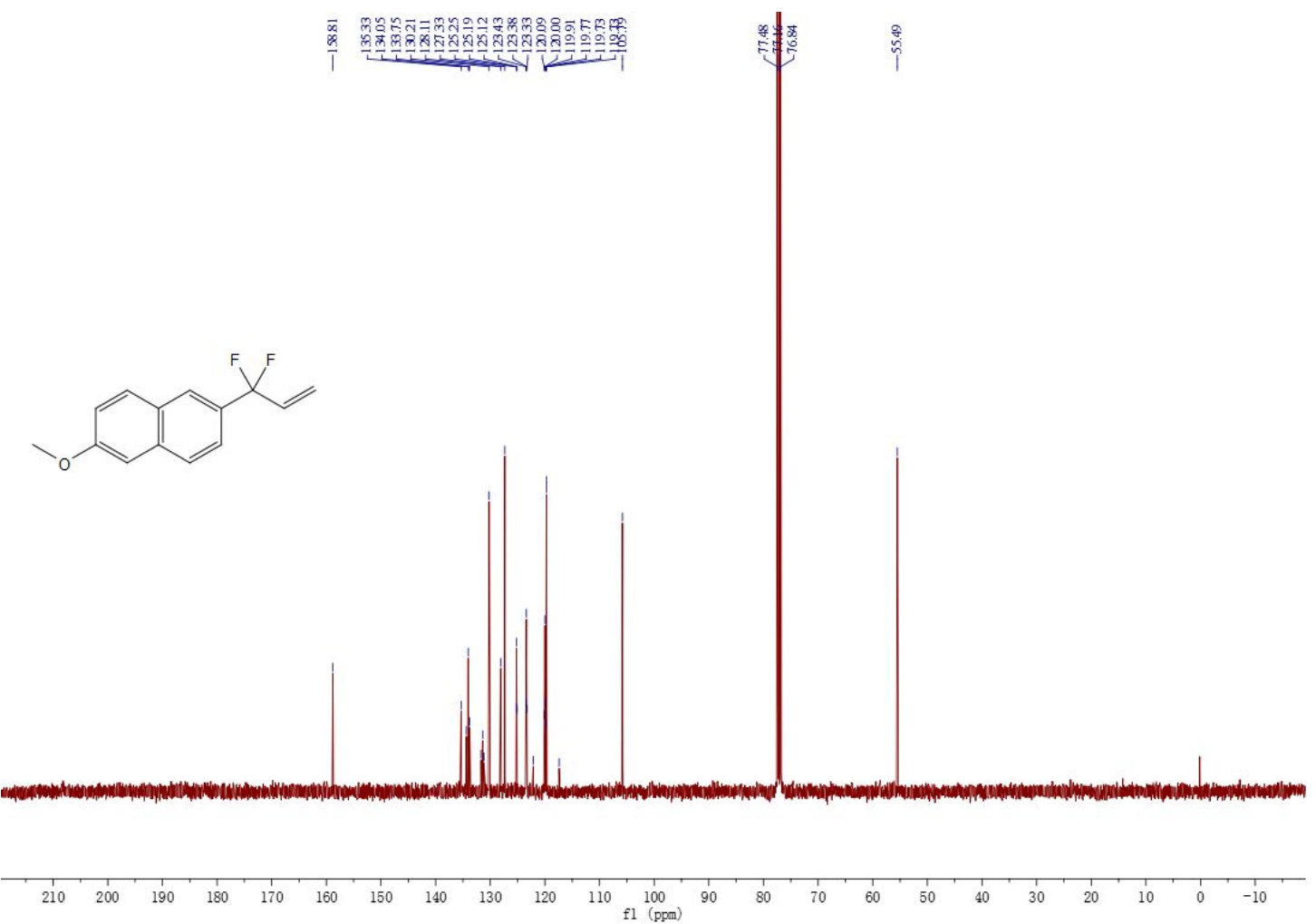
${ }^{1} \mathrm{H}\left(400 \mathrm{MHz}, \mathrm{CDCl}_{3}\right)$ of $\mathbf{3 c}$

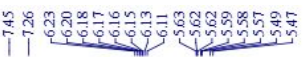

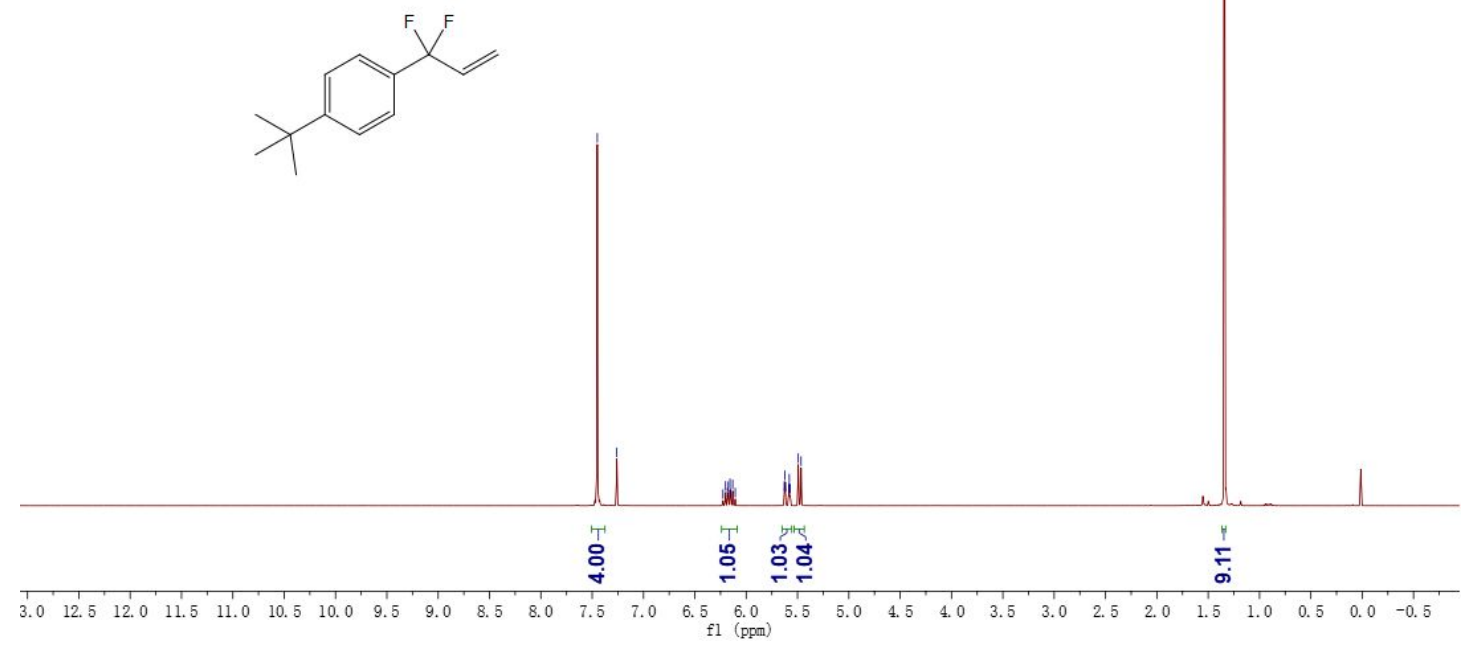

${ }^{19} \mathrm{~F}\left(376 \mathrm{MHz}, \mathrm{CDCl}_{3}\right)$ of $\mathbf{3 c}$

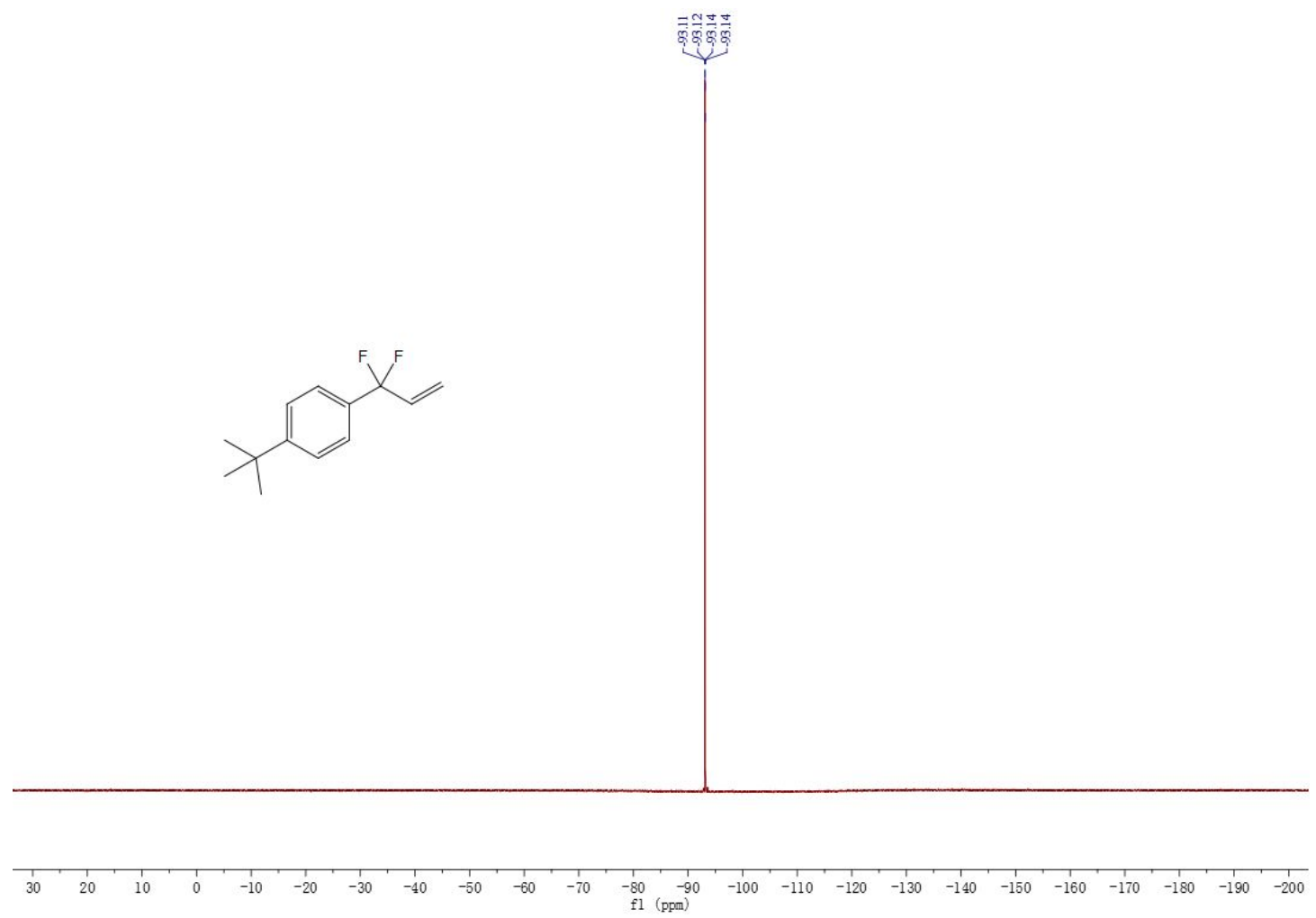


${ }^{13} \mathrm{C}\left\{{ }^{1} \mathrm{H}\right\}\left(101 \mathrm{MHz}, \mathrm{CDCl}_{3}\right)$ of $\mathbf{3 c}$

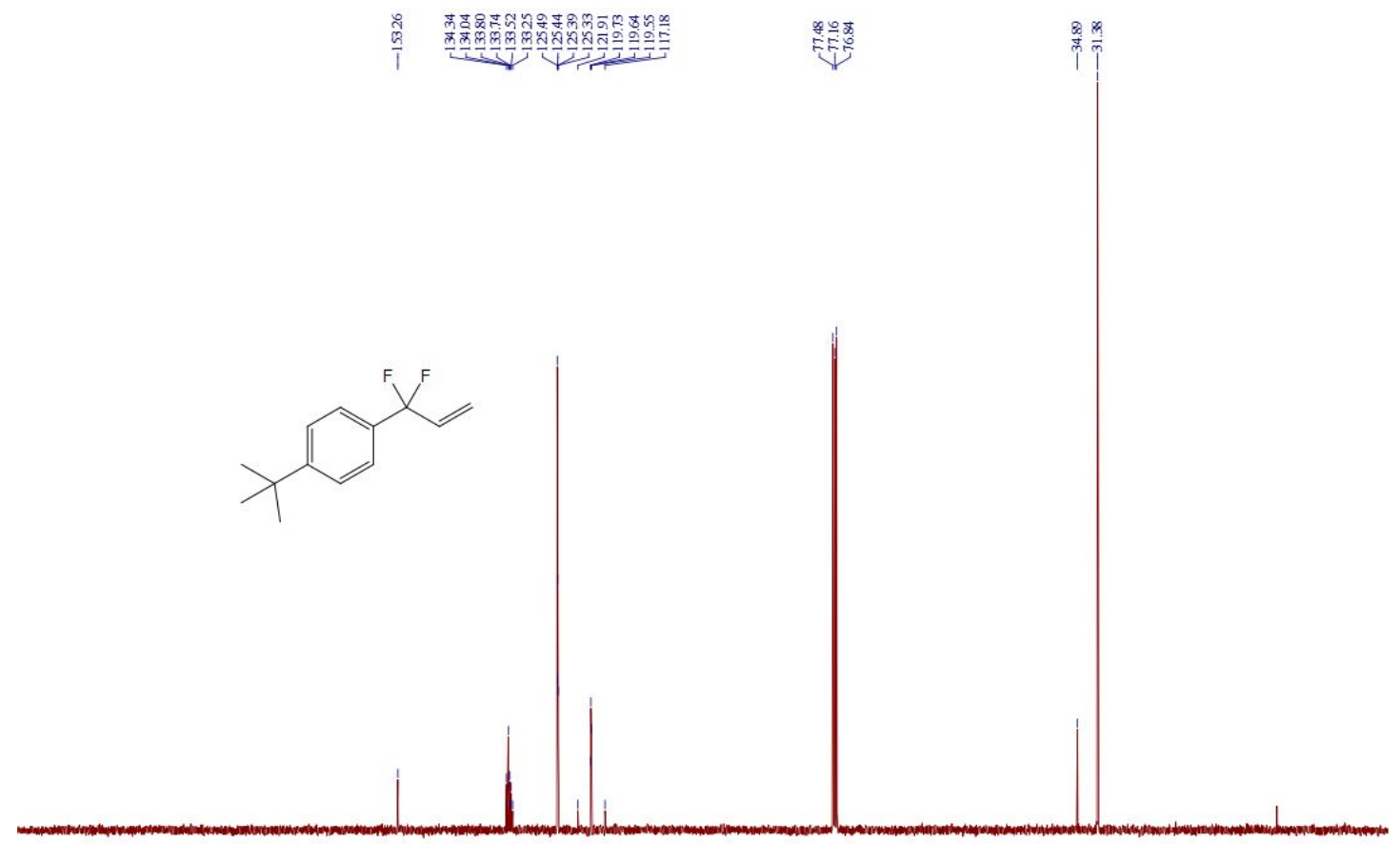

${ }^{1} \mathrm{H}\left(400 \mathrm{MHz}, \mathrm{CDCl}_{3}\right)$ of $\mathbf{3 d}$

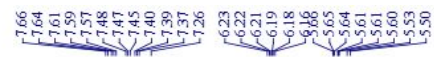
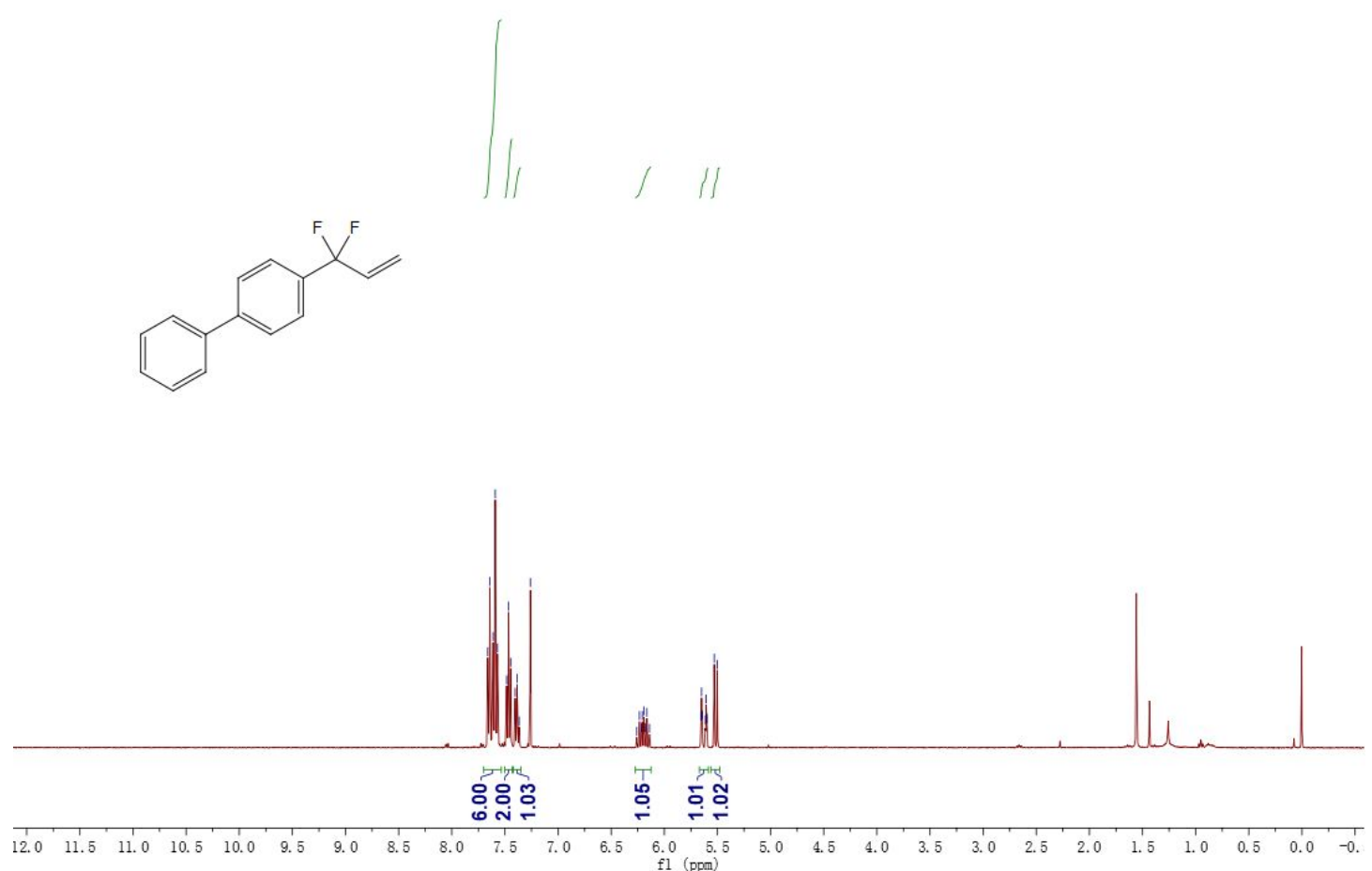
${ }^{19} \mathrm{~F}\left(376 \mathrm{MHz}, \mathrm{CDCl}_{3}\right)$ of $\mathbf{3 d}$

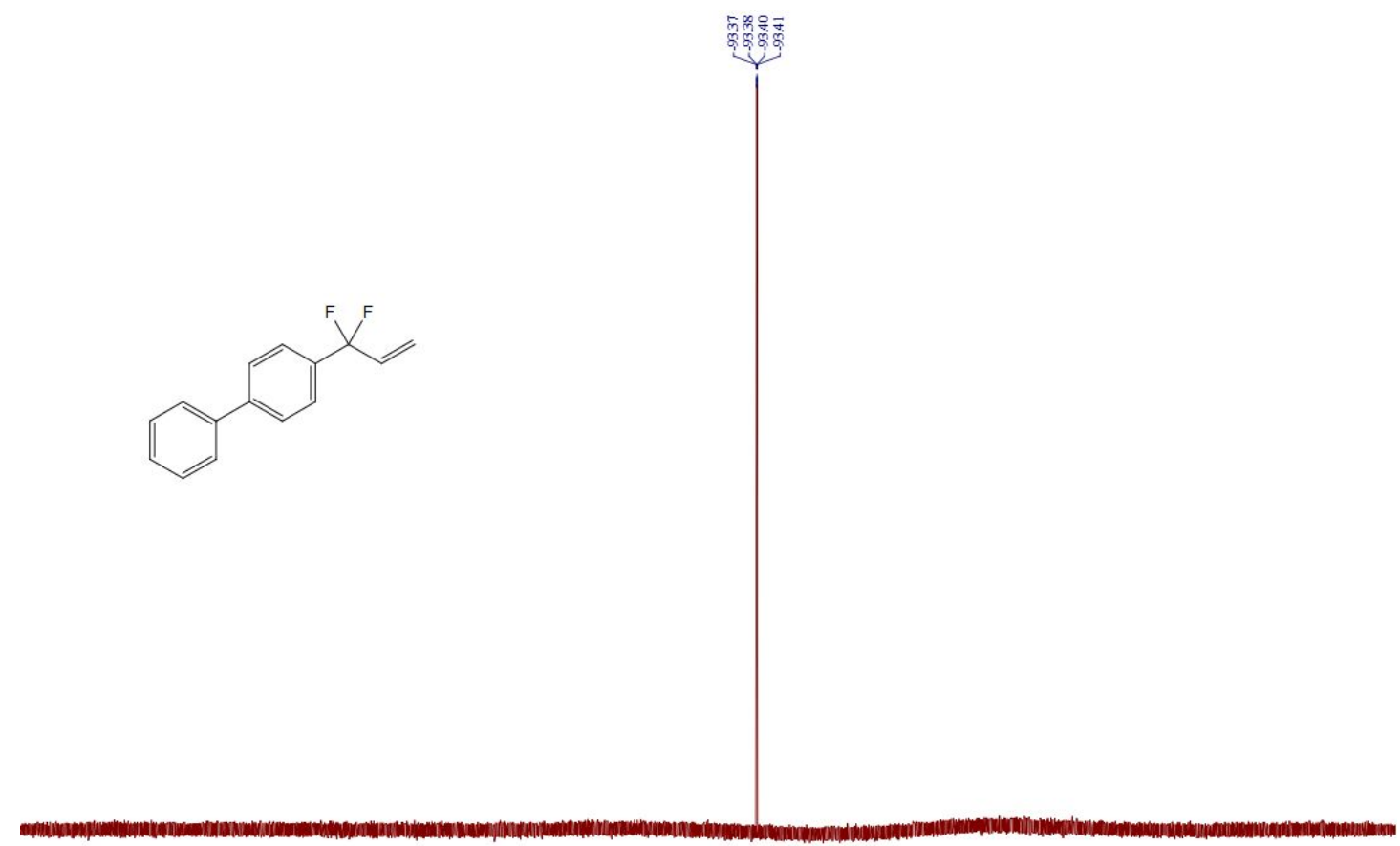

\begin{tabular}{llllllllllllllllllllllllllllll}
30 & 20 & 10 & 0 & -10 & -20 & -30 & -40 & -50 & -60 & -70 & -80 & -90 & -100 & -110 & -120 & -130 & -140 & -150 & -160 & -170 & -180 & -190 & -200 \\
\hline
\end{tabular}

${ }^{13} \mathrm{C}\left\{{ }^{1} \mathrm{H}\right\}\left(176 \mathrm{MHz}, \mathrm{CDCl}_{3}\right)$ of $\mathbf{3 d}$

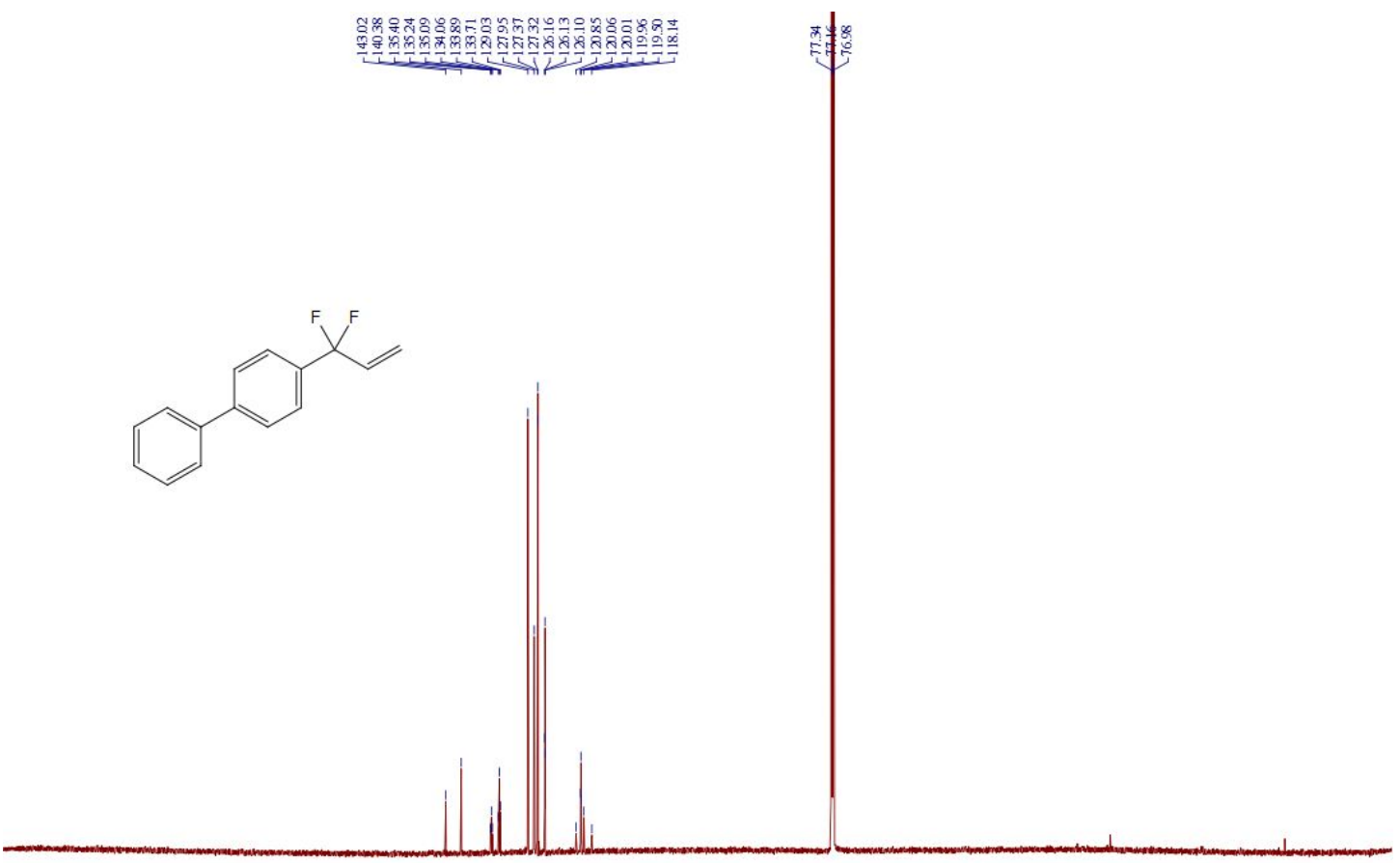


${ }^{1} \mathrm{H}\left(400 \mathrm{MHz}, \mathrm{CDCl}_{3}\right)$ of $\mathbf{3 e}$

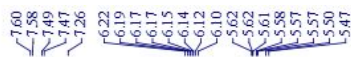
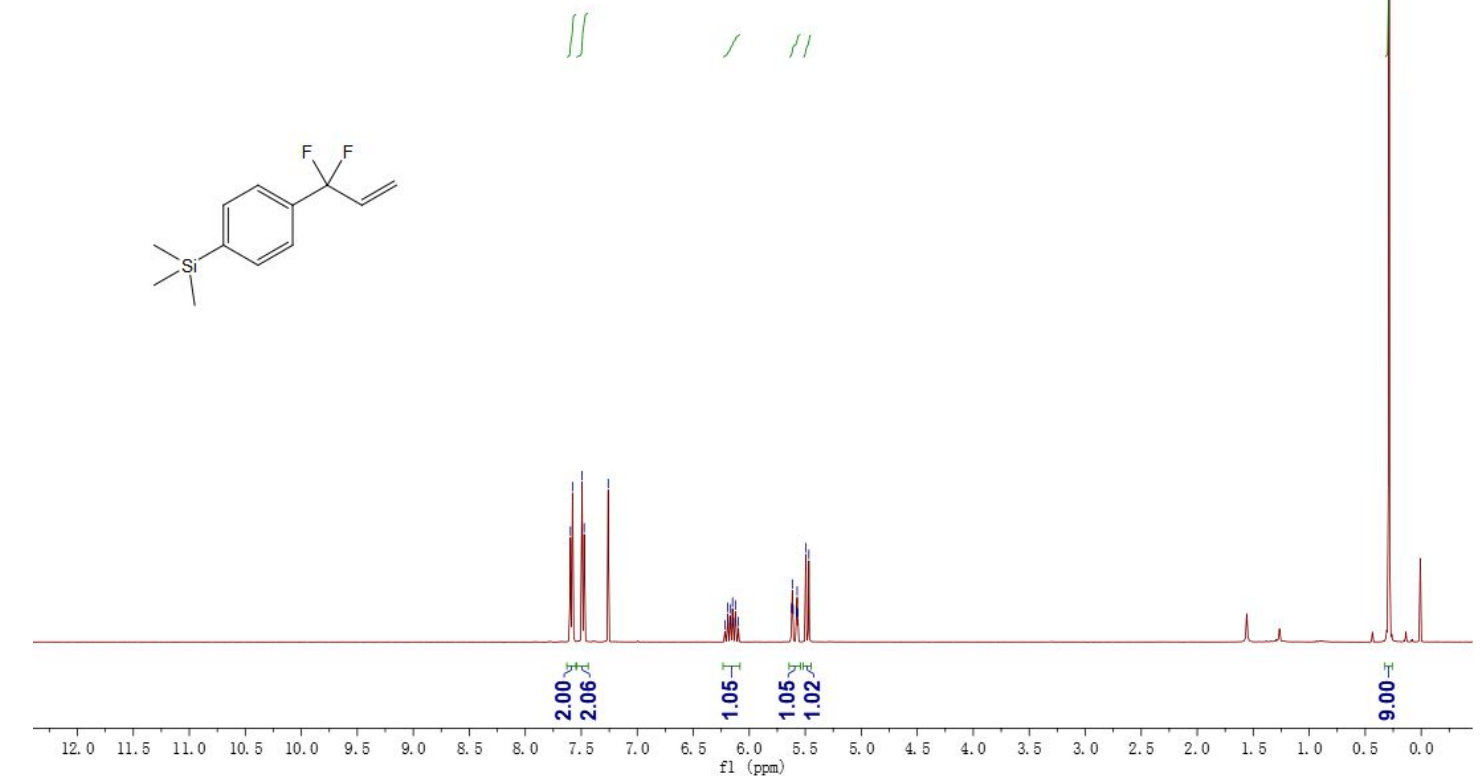

${ }^{19} \mathrm{~F}\left(376 \mathrm{MHz}, \mathrm{CDCl}_{3}\right)$ of $\mathbf{3 e}$

亭等葶
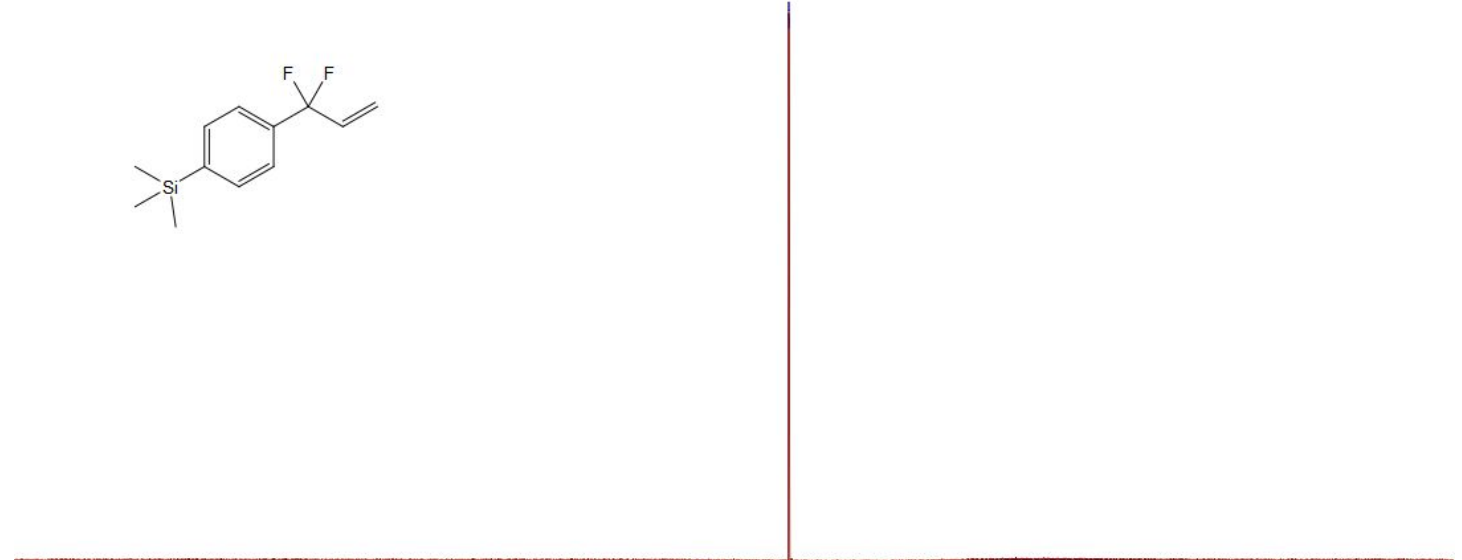

$30 \quad 20$

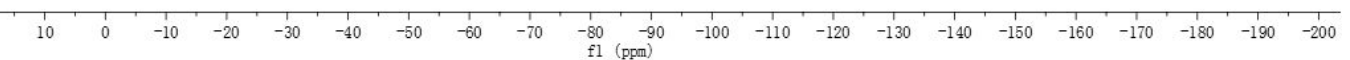


${ }^{13} \mathrm{C}\left\{{ }^{1} \mathrm{H}\right\}\left(101 \mathrm{MHz}, \mathrm{CDCl}_{3}\right)$ of $\mathbf{3 e}$

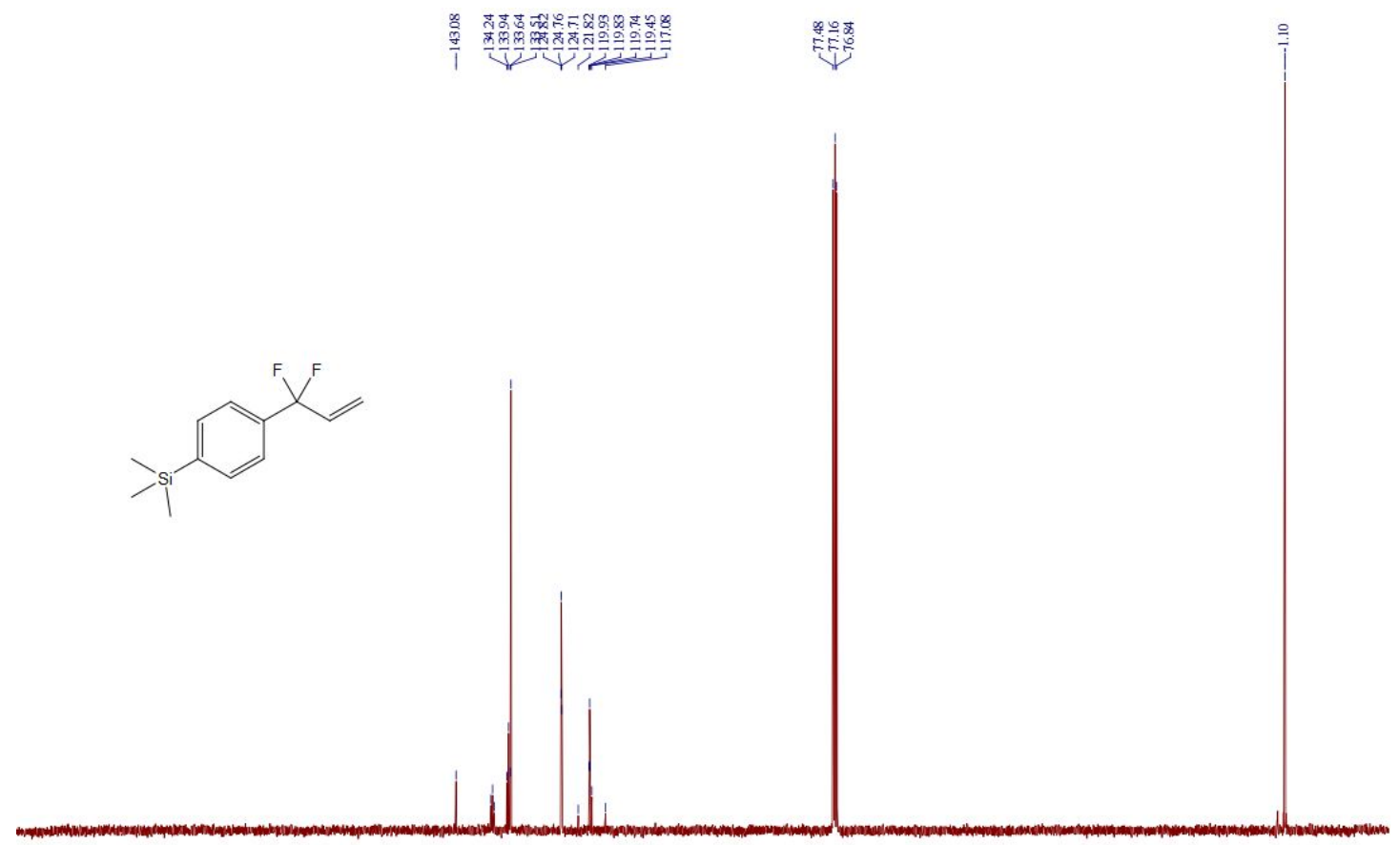

${ }^{1} \mathrm{H}\left(400 \mathrm{MHz}, \mathrm{CDCl}_{3}\right)$ of $\mathbf{3 f}$

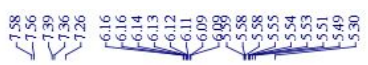

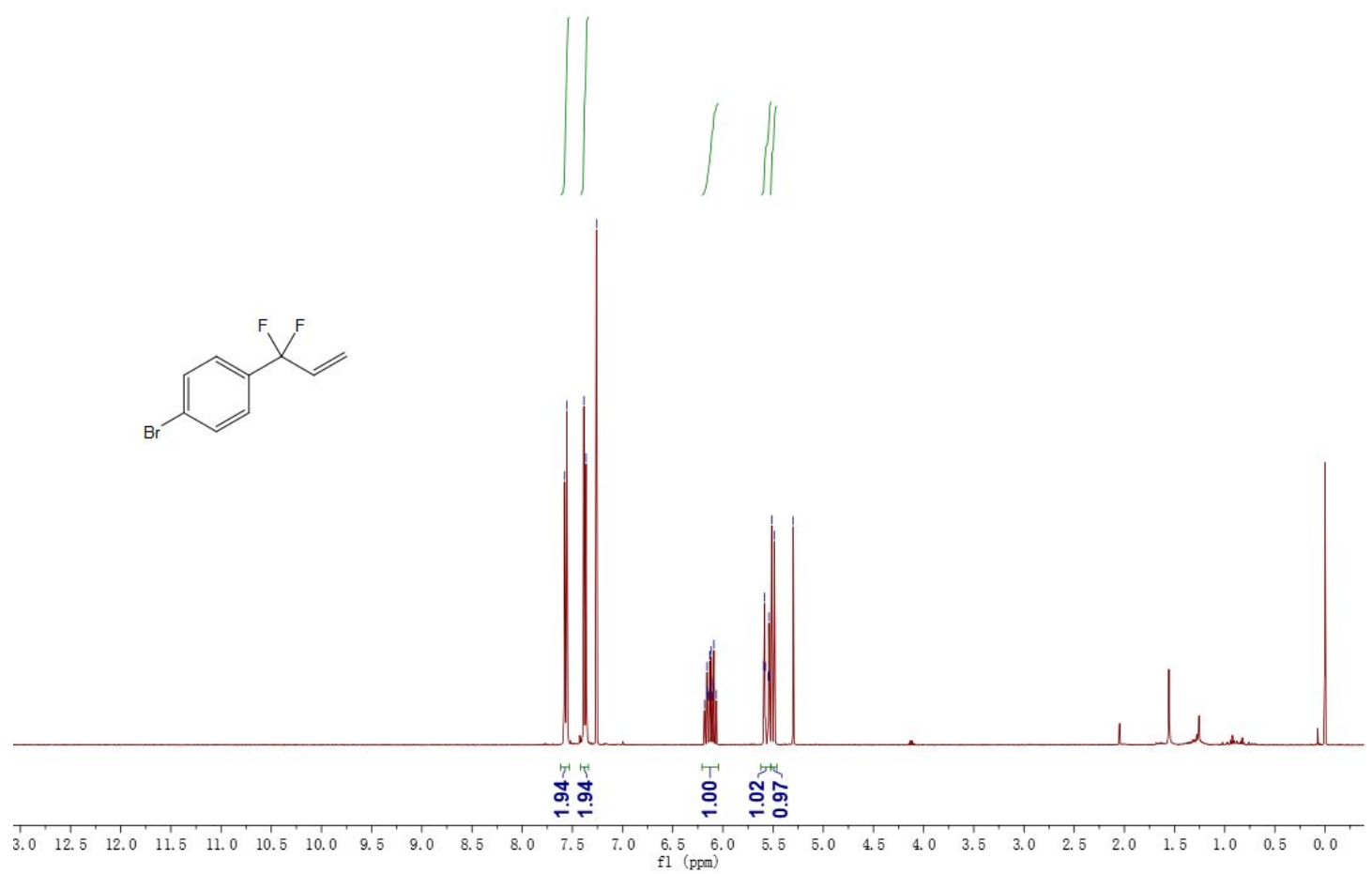


${ }^{19} \mathrm{~F}\left(376 \mathrm{MHz}, \mathrm{CDCl}_{3}\right)$ of $\mathbf{3 f}$

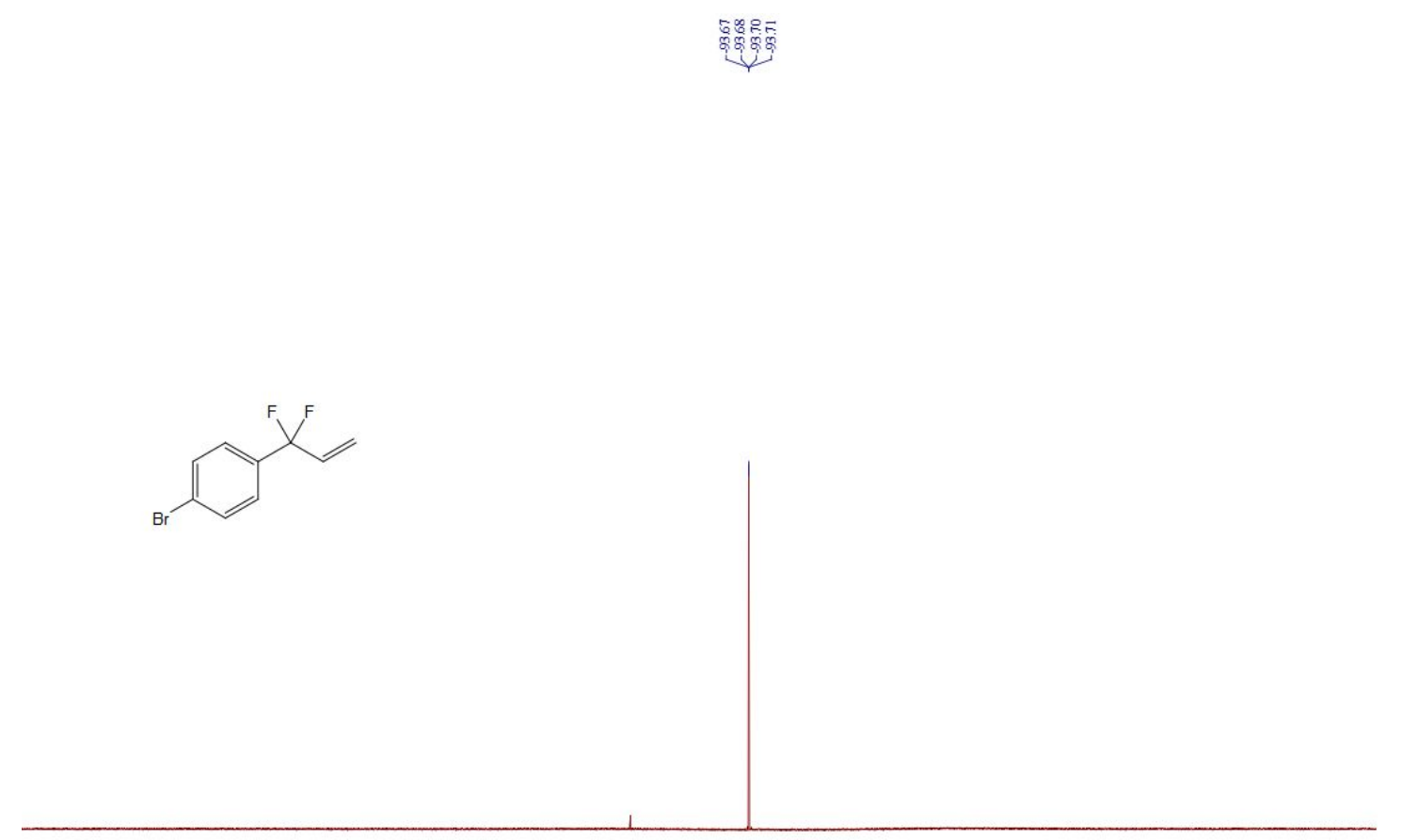

\begin{tabular}{lllllllllllllllllllllllllllll}
30 & 20 & 10 & 0 & -10 & -20 & -30 & -40 & -50 & -60 & -70 & -80 & -90 & -100 & -110 & -120 & -130 & -140 & -150 & -160 & -170 & -180 & -190 & -200 \\
\hline
\end{tabular}

${ }^{13} \mathrm{C}\left\{{ }^{1} \mathrm{H}\right\}\left(101 \mathrm{MHz}, \mathrm{CDCl}_{3}\right)$ of $\mathbf{3 f}$

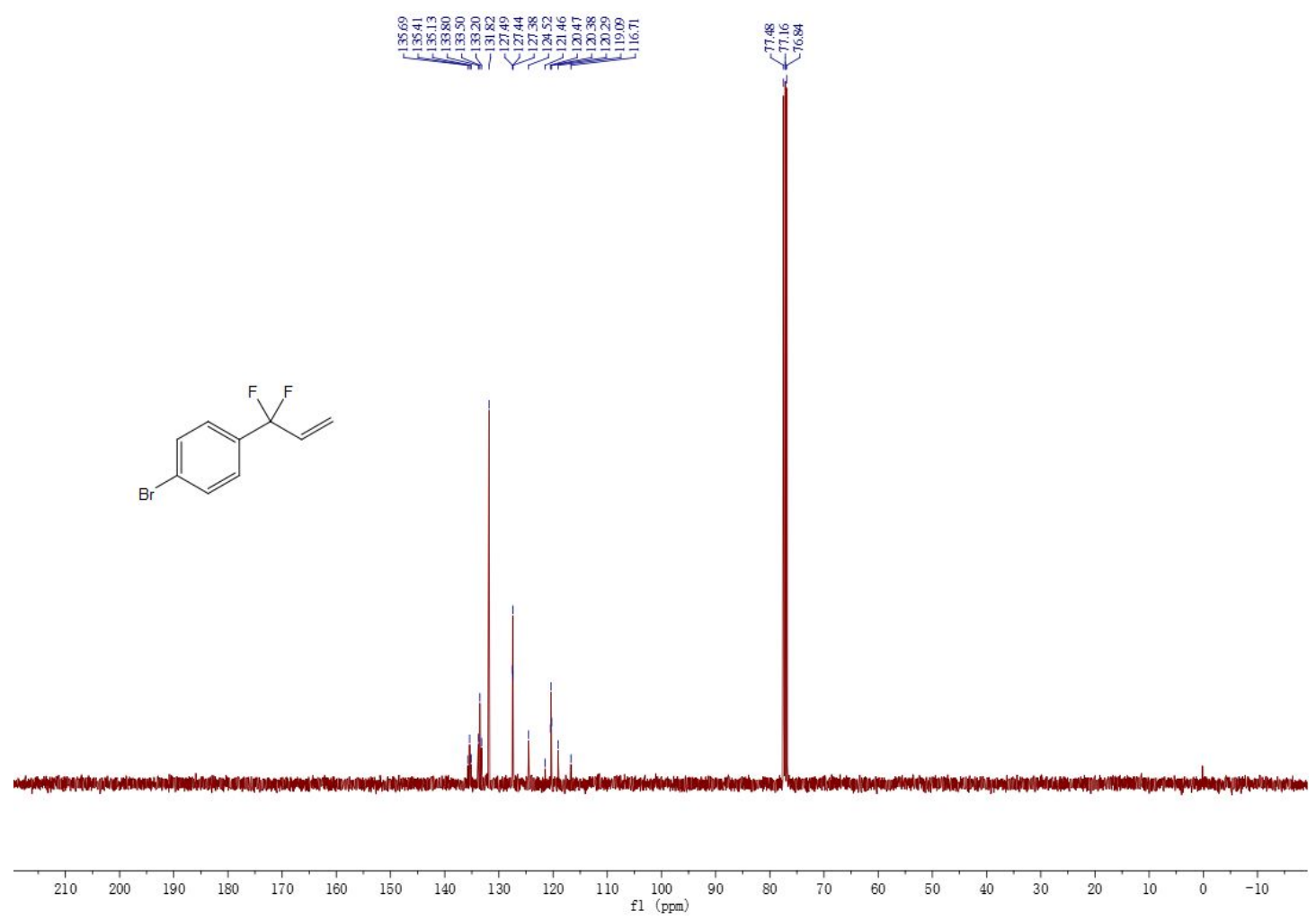


${ }^{1} \mathrm{H}\left(400 \mathrm{MHz}, \mathrm{CDCl}_{3}\right)$ of $\mathbf{3 g}$

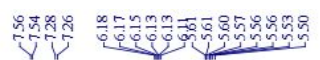

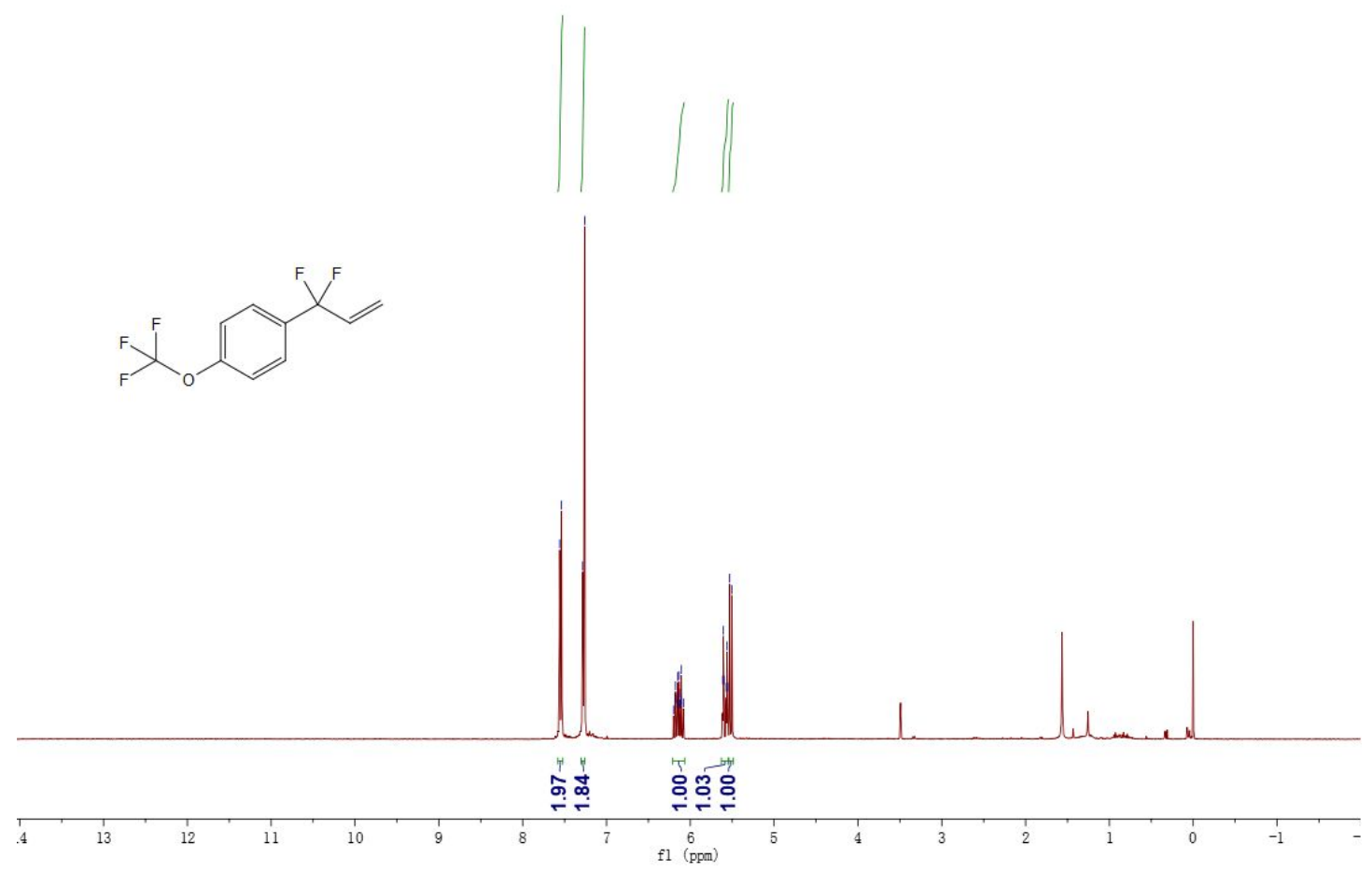

${ }^{19} \mathrm{~F}\left(376 \mathrm{MHz}, \mathrm{CDCl}_{3}\right)$ of $\mathbf{3 g}$

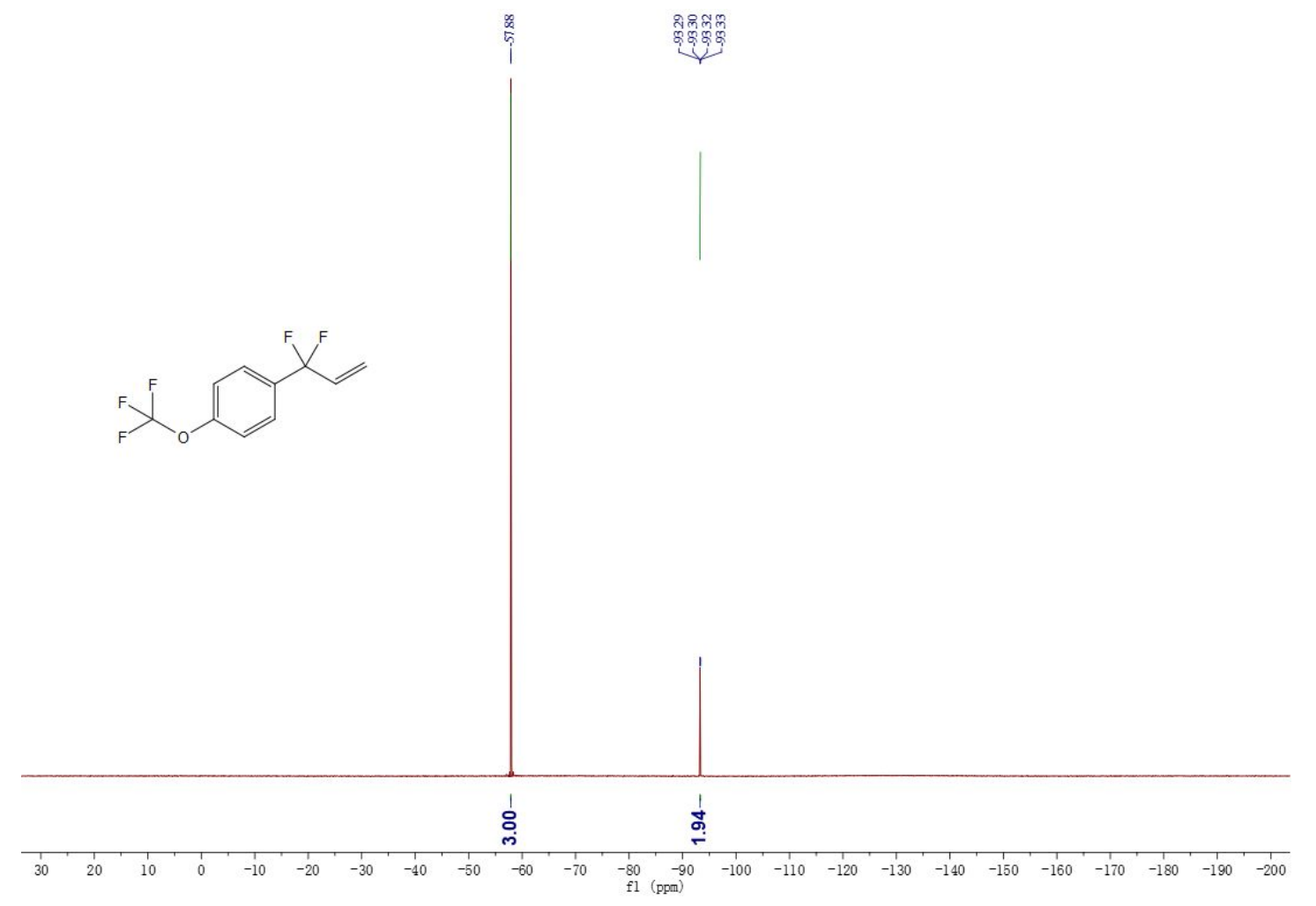


${ }^{13} \mathrm{C}\left\{{ }^{1} \mathrm{H}\right\}\left(101 \mathrm{MHz}, \mathrm{CDCl}_{3}\right)$ of $\mathbf{3 g}$

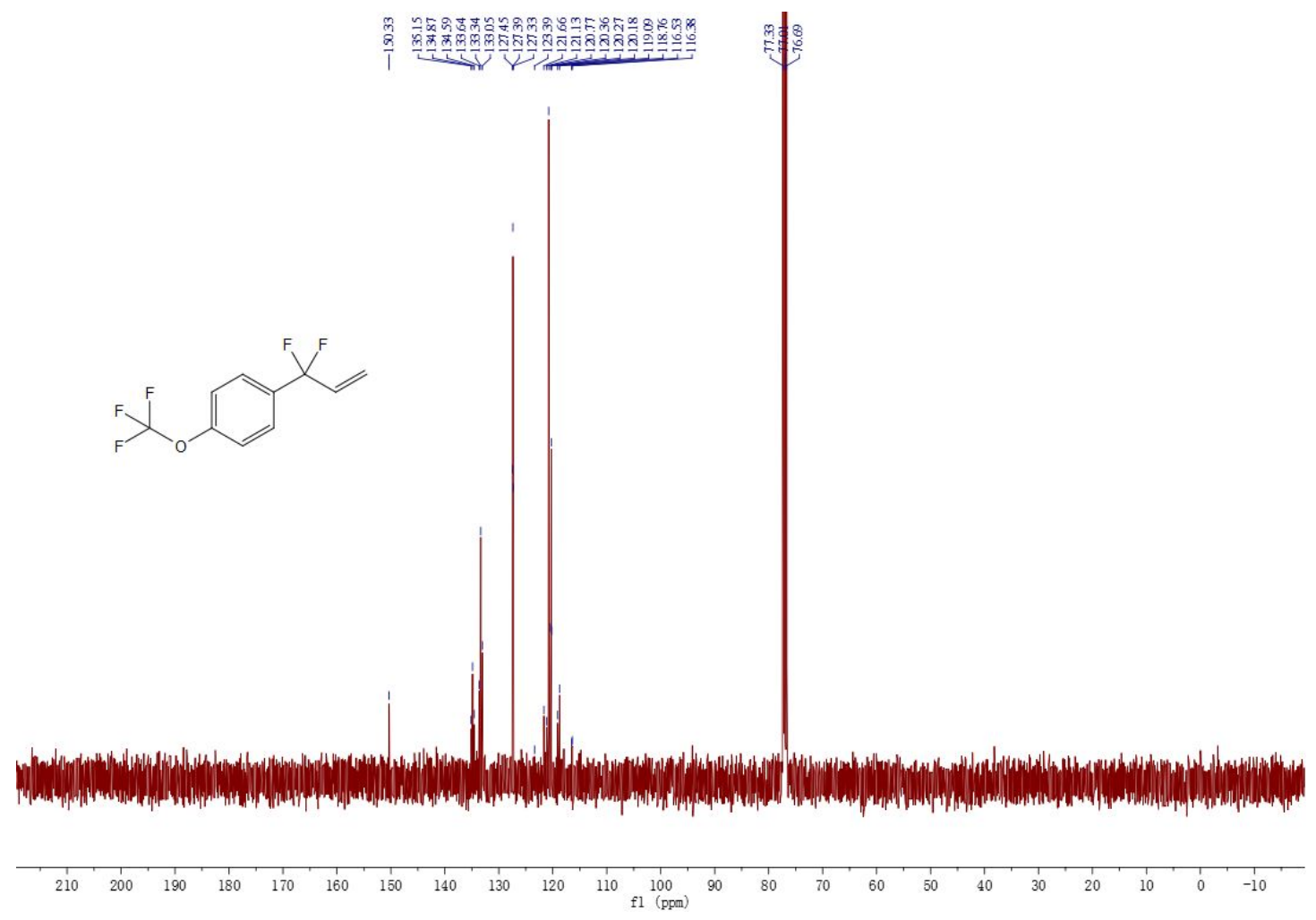

${ }^{1} \mathrm{H}\left(400 \mathrm{MHz}, \mathrm{CDCl}_{3}\right)$ of $\mathbf{3 h}$
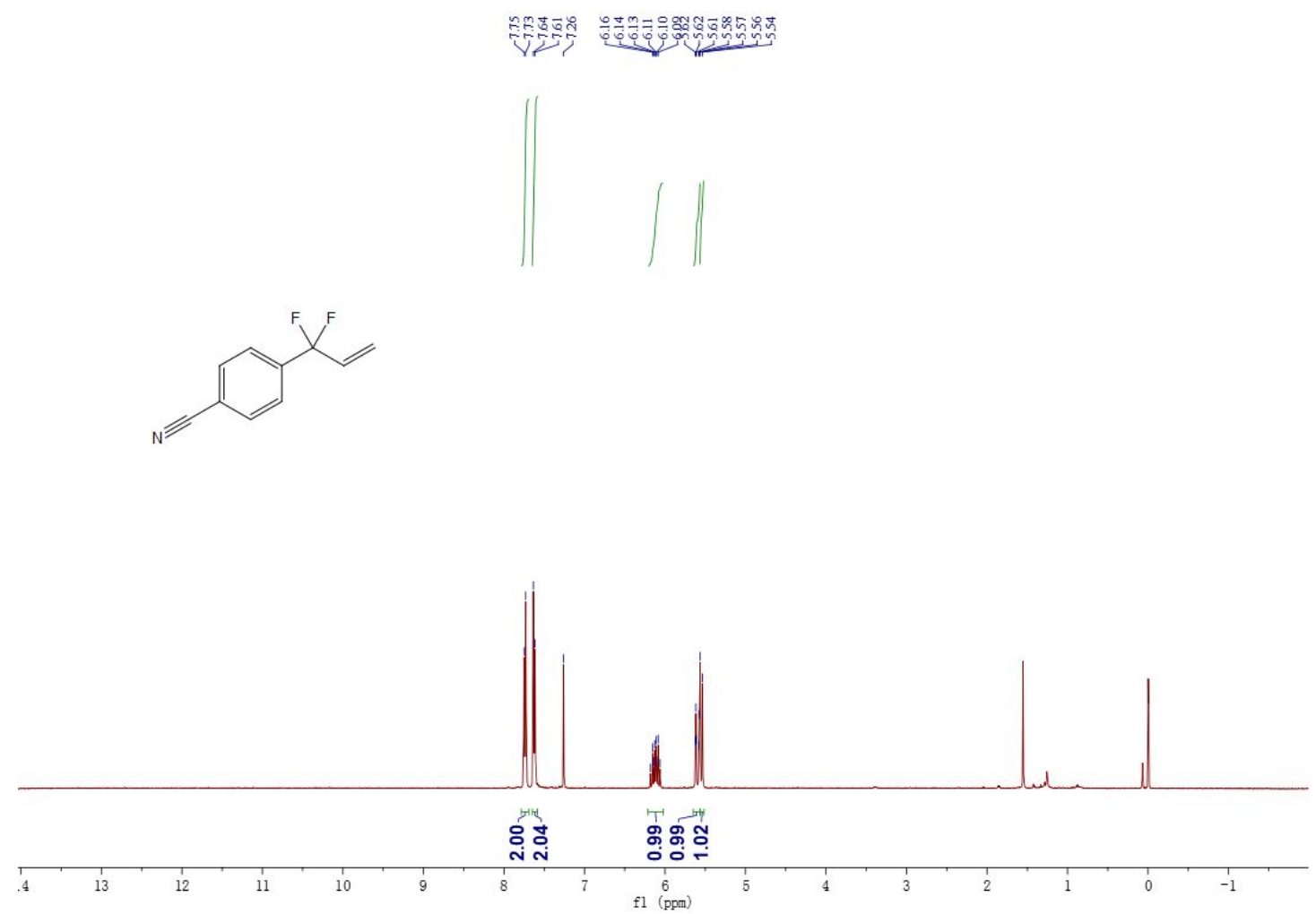
${ }^{19} \mathrm{~F}\left(376 \mathrm{MHz}, \mathrm{CDCl}_{3}\right)$ of $\mathbf{3 h}$

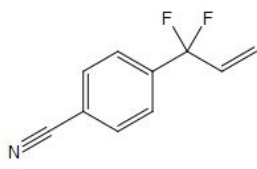

\begin{tabular}{llllllllllllllllllllllllllllllllll}
\hline & 1 & 1 & 1 & 10 & 0 & -10 & -20 & -30 & -40 & -50 & -60 & -70 & -80 & -90 & -100 & -110 & -120 & -130 & -140 & -150 & -160 & -170 & -180 & -190 & -200
\end{tabular}

${ }^{13} \mathrm{C}\left\{{ }^{1} \mathrm{H}\right\}\left(176 \mathrm{MHz}, \mathrm{CDCl}_{3}\right)$ of $\mathbf{3 h}$
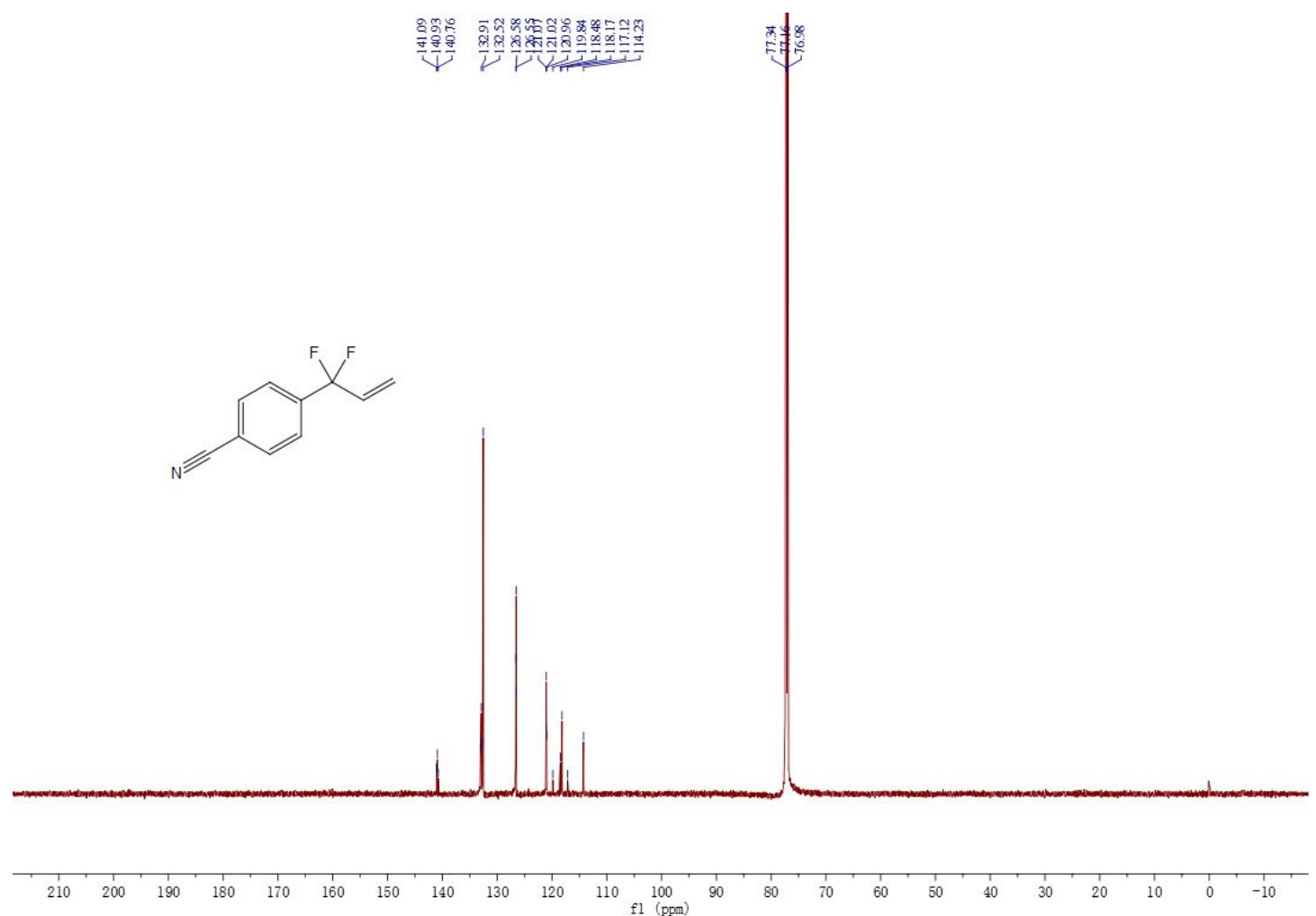
${ }^{1} \mathrm{H}\left(400 \mathrm{MHz}, \mathrm{CDCl}_{3}\right)$ of $\mathbf{3 i}$

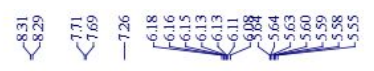
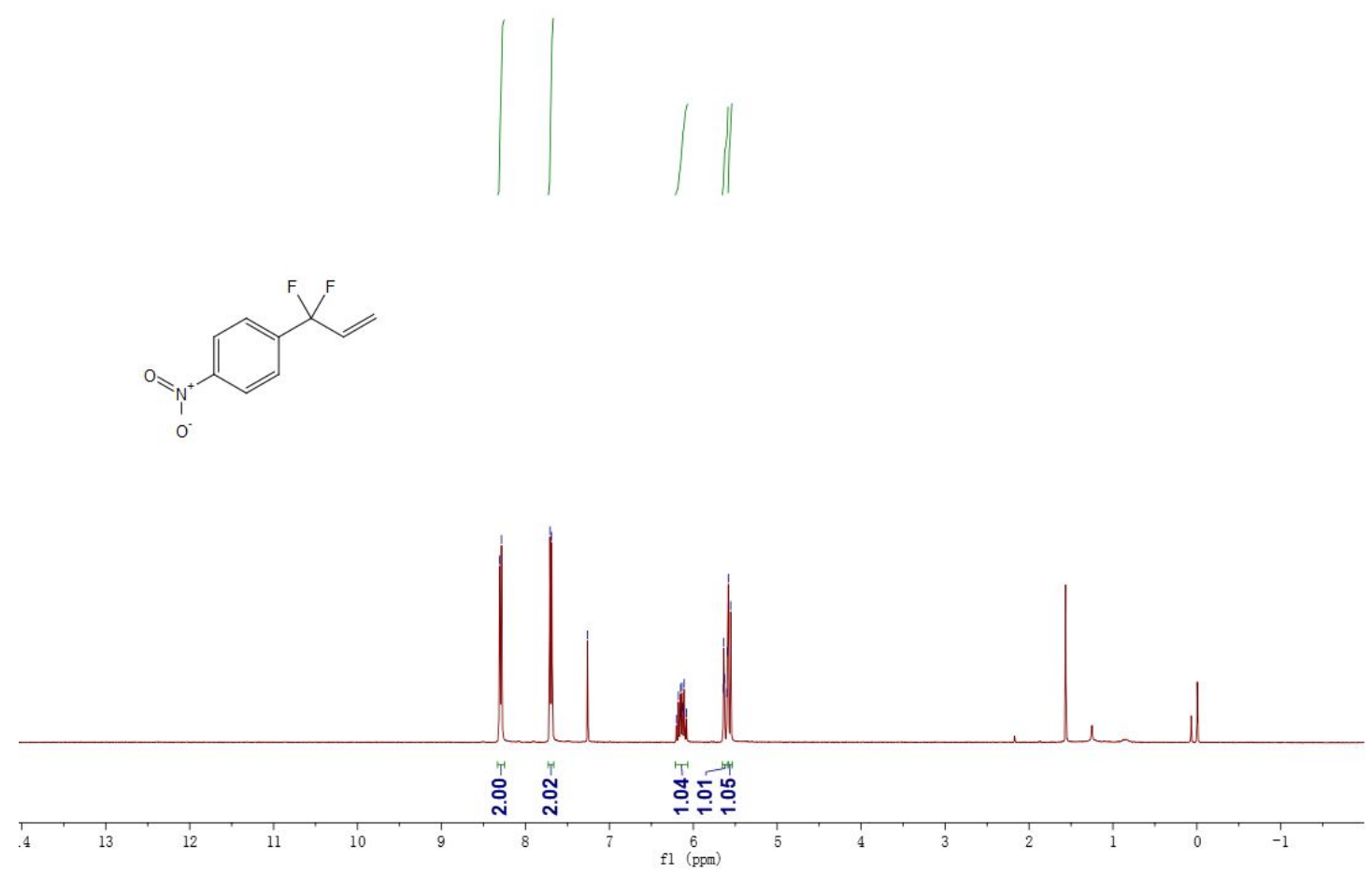

${ }^{19} \mathrm{~F}\left(376 \mathrm{MHz}, \mathrm{CDCl}_{3}\right)$ of $\mathbf{3 i}$

管果

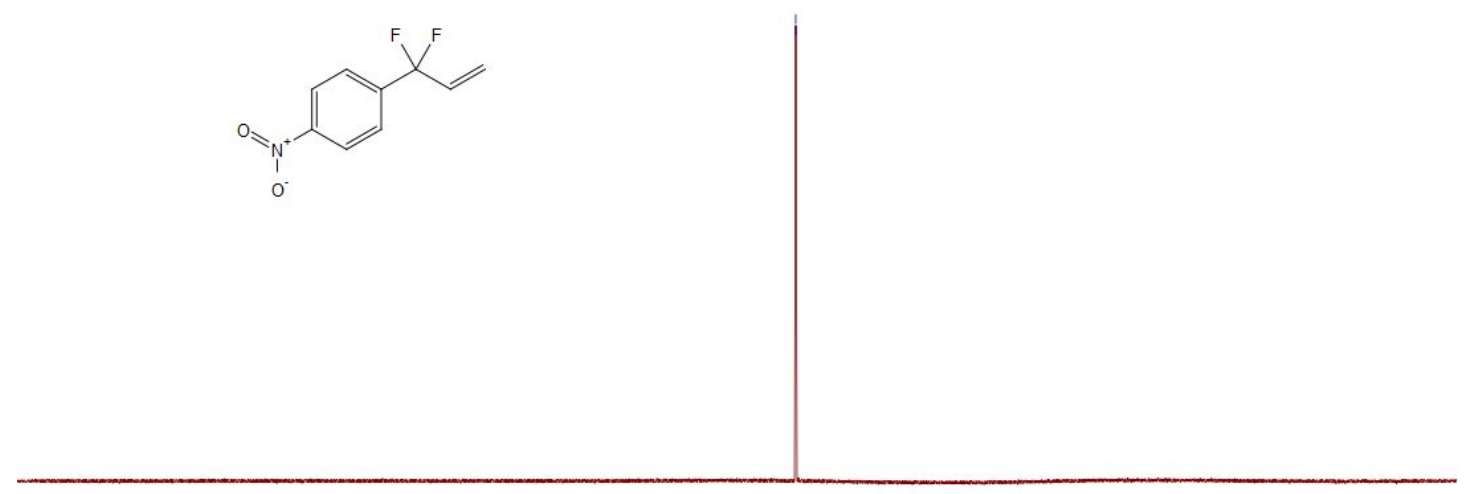

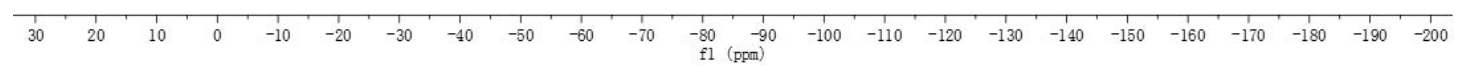


${ }^{13} \mathrm{C}\left\{{ }^{1} \mathrm{H}\right\}\left(176 \mathrm{MHz}, \mathrm{CDCl}_{3}\right)$ of $\mathbf{3 i}$

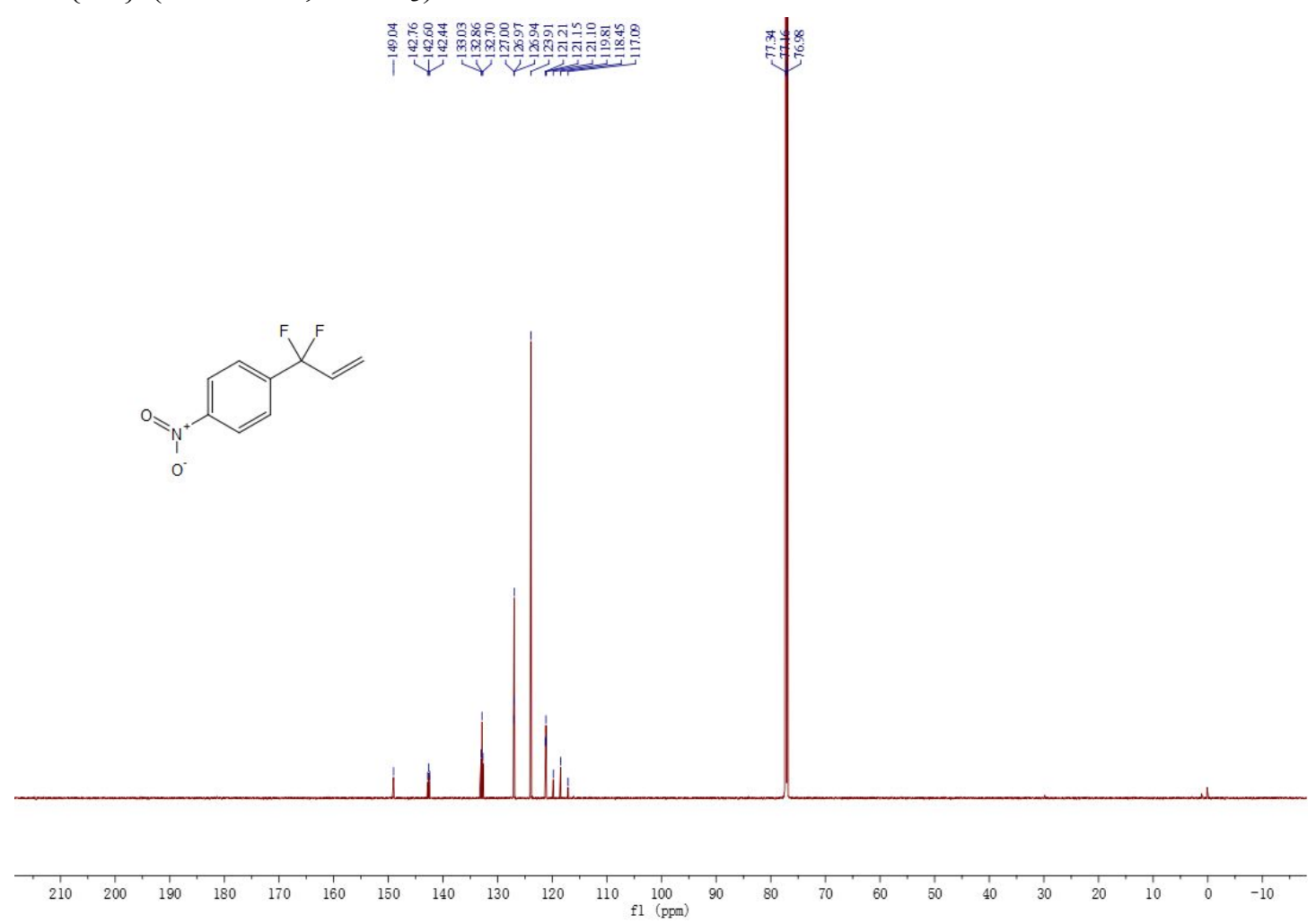

\section{${ }^{1} \mathrm{H}\left(400 \mathrm{MHz}, \mathrm{CDCl}_{3}\right)$ of $\mathbf{3 j}$}

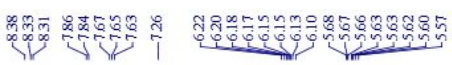
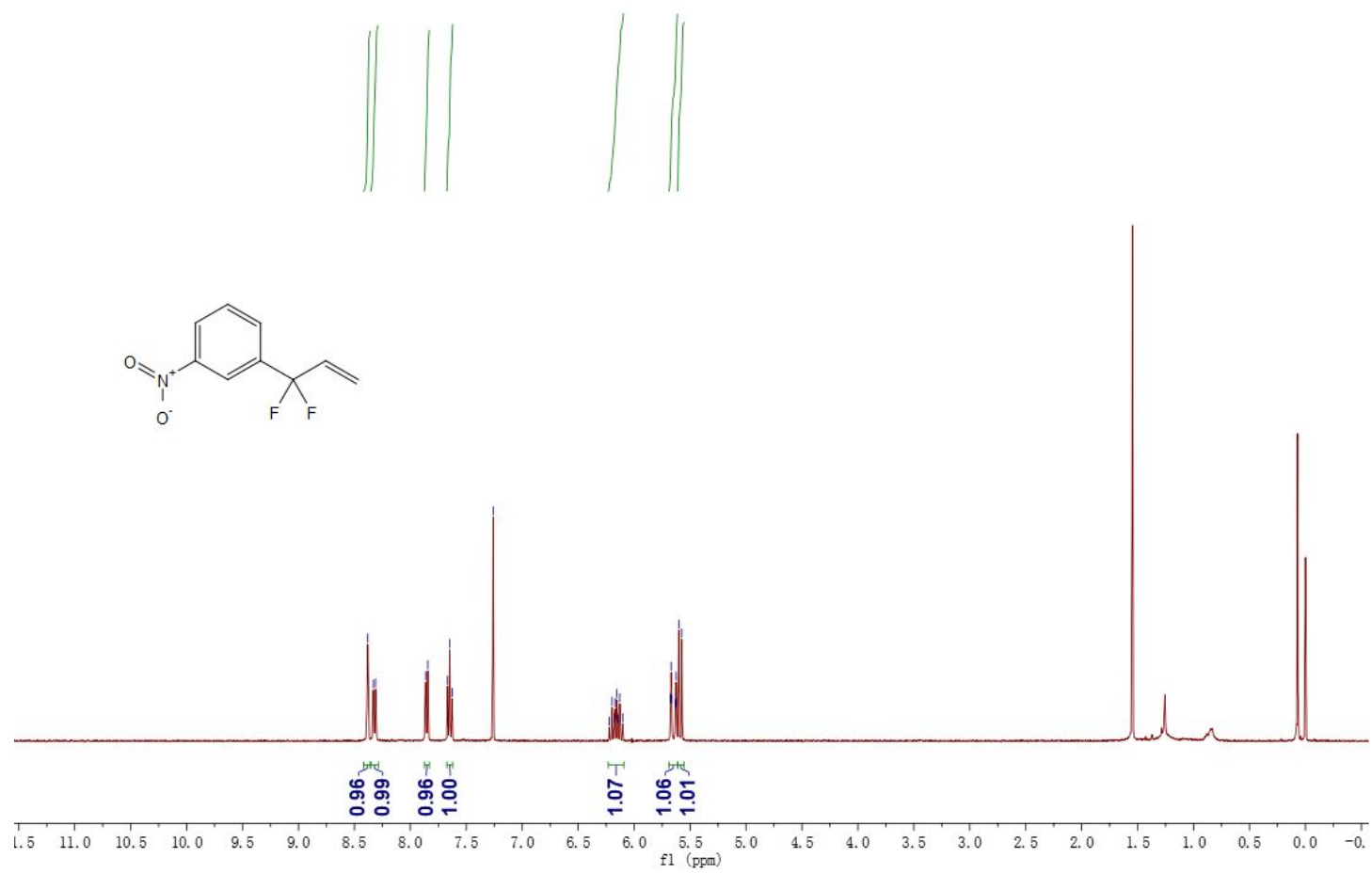
${ }^{19} \mathrm{~F}\left(376 \mathrm{MHz}, \mathrm{CDCl}_{3}\right)$ of $\mathbf{3 j}$

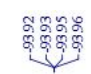

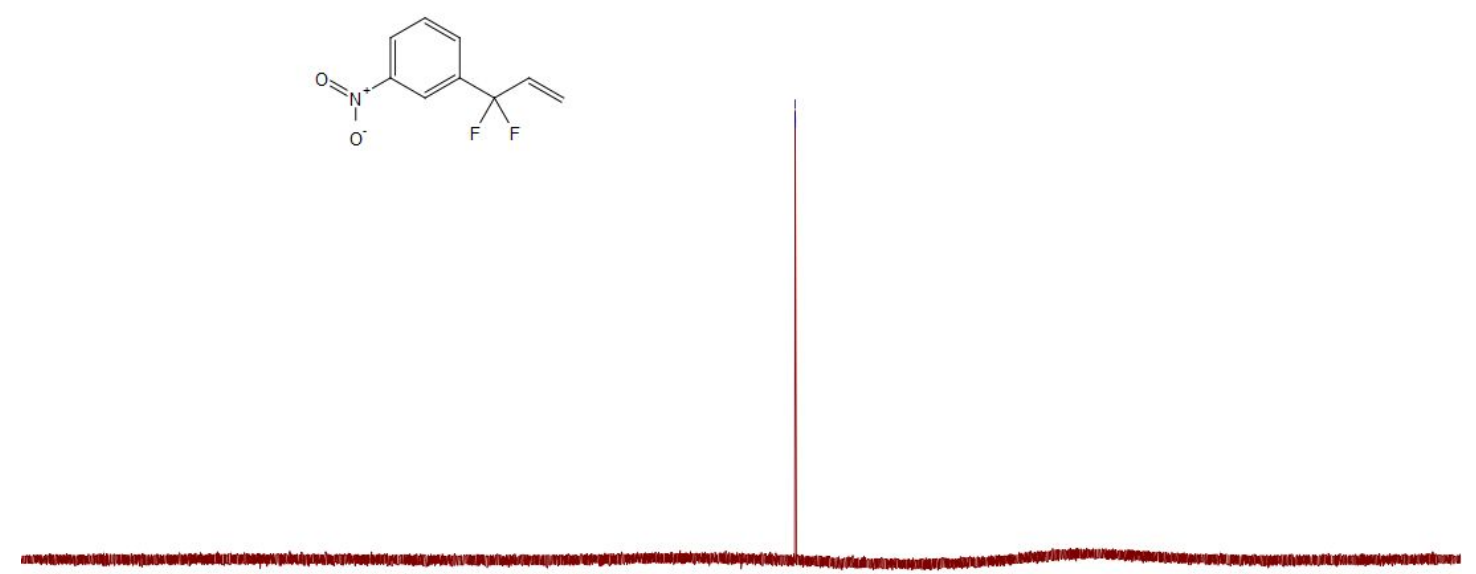

${ }^{13} \mathrm{C}\left\{{ }^{1} \mathrm{H}\right\}\left(101 \mathrm{MHz}, \mathrm{CDCl}_{3}\right)$ of $\mathbf{3 j}$

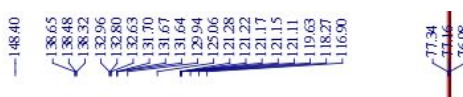<smiles>CC(C)C1CCC(C2(C)CCCC2)C1</smiles>

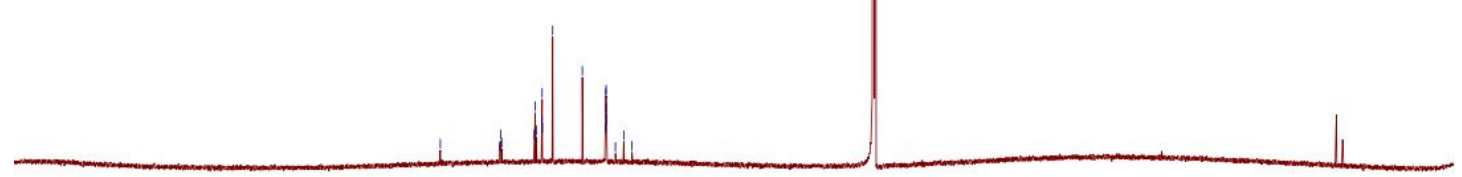

$\begin{array}{lllllllllllllllllllllllllllllllllllll}1 & 1 & 200 & 190 & 180 & 170 & 160 & 150 & 140 & 130 & 120 & 110 & 100 & 90 & 80 & 70 & 60 & 50 & 40 & 30 & 20 & 10 & 0 & -10\end{array}$ 
${ }^{1} \mathrm{H}\left(400 \mathrm{MHz}, \mathrm{CDCl}_{3}\right)$ of $\mathbf{3 k}$
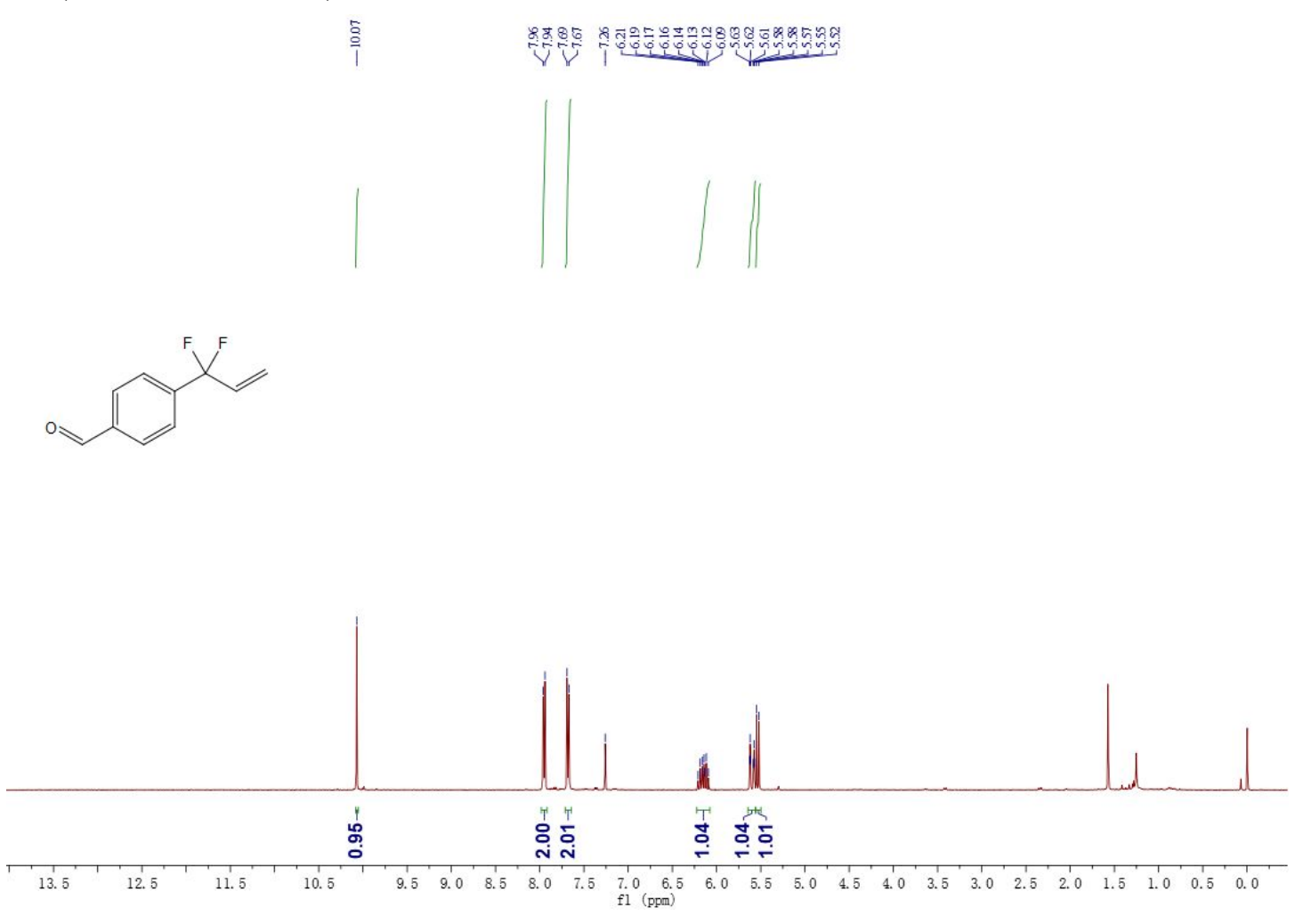

${ }^{19} \mathrm{~F}\left(376 \mathrm{MHz}, \mathrm{CDCl}_{3}\right)$ of $\mathbf{3 k}$

喓需早

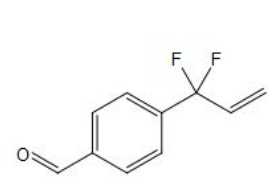

S45 
${ }^{13} \mathrm{C}\left\{{ }^{1} \mathrm{H}\right\}\left(101 \mathrm{MHz}, \mathrm{CDCl}_{3}\right)$ of $\mathbf{3 k}$
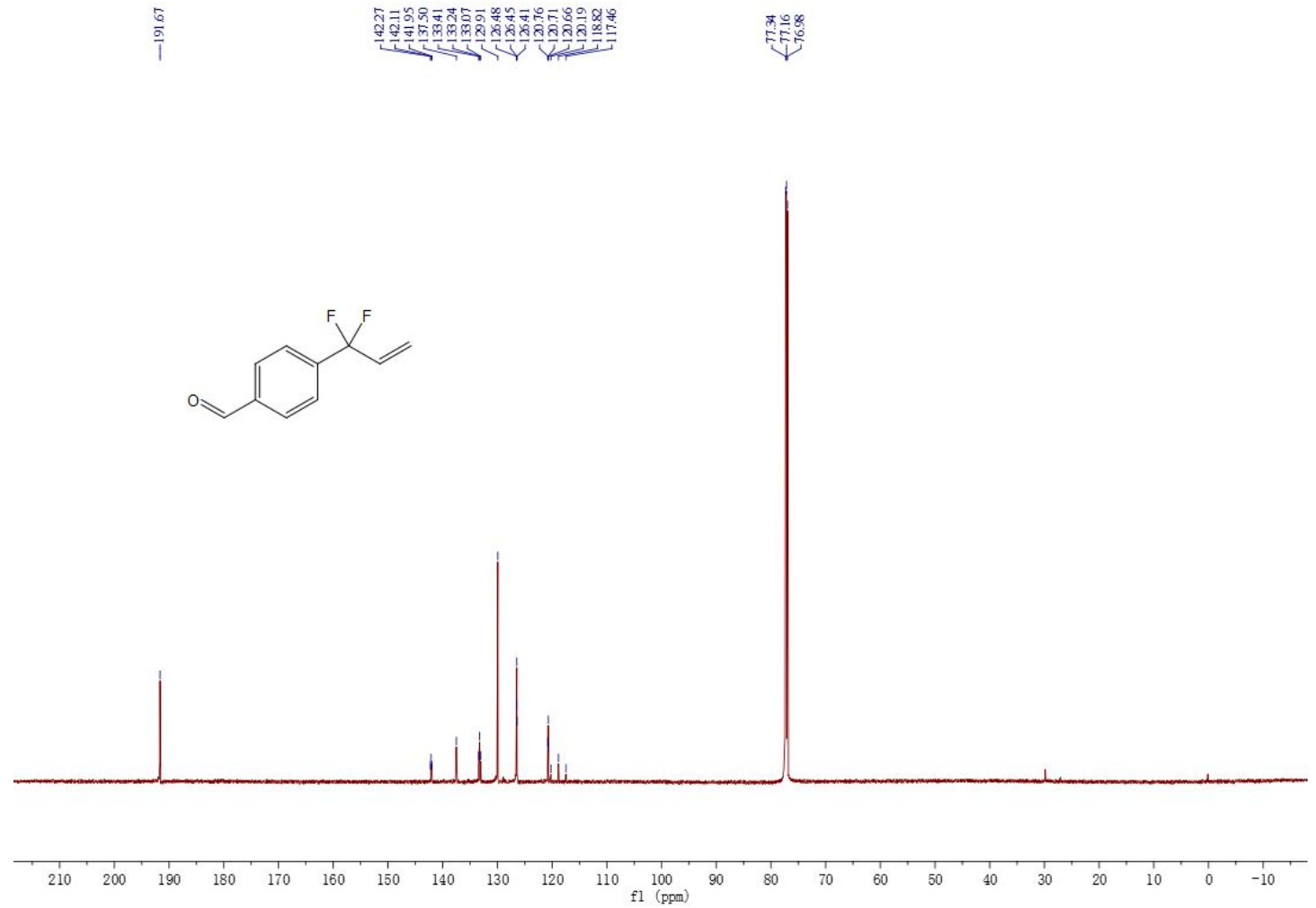

${ }^{1} \mathrm{H}\left(400 \mathrm{MHz}, \mathrm{CDCl}_{3}\right)$ of $\mathbf{3 l}$

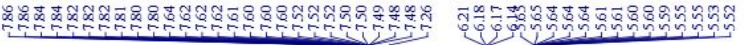

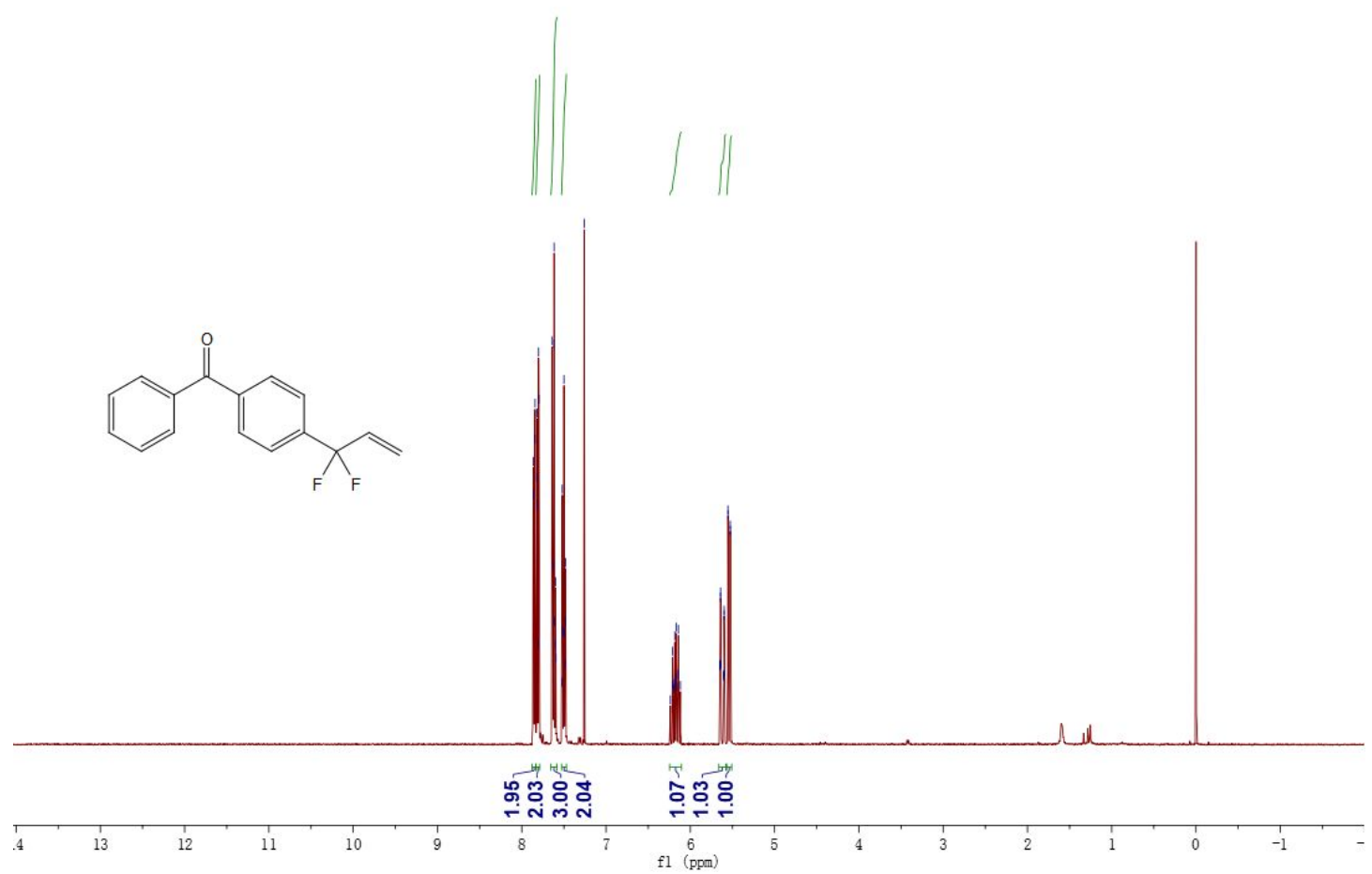


${ }^{19} \mathrm{~F}\left(376 \mathrm{MHz}, \mathrm{CDCl}_{3}\right)$ of $\mathbf{3 I}$

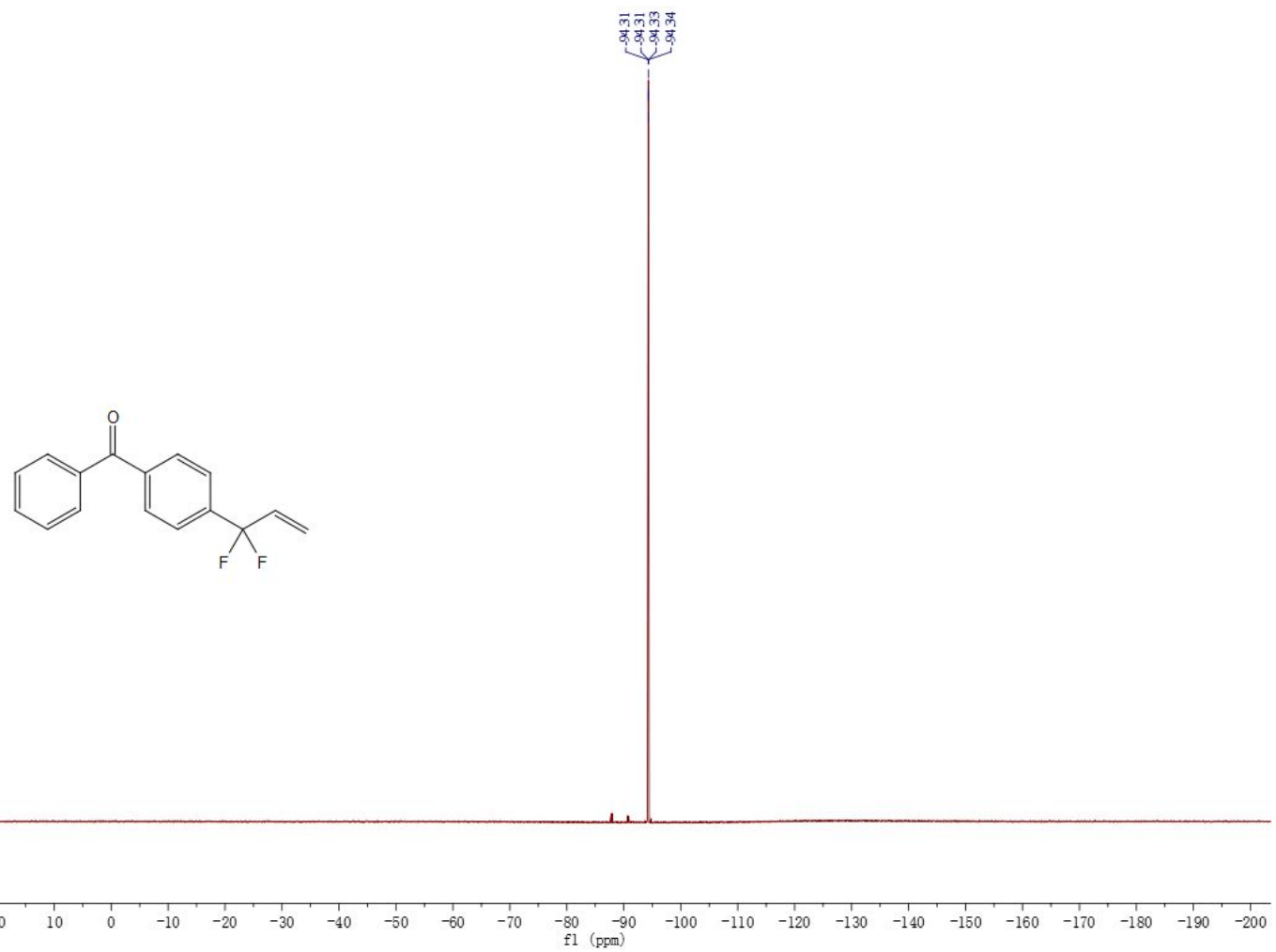

${ }^{13} \mathrm{C}\left\{{ }^{1} \mathrm{H}\right\}\left(101 \mathrm{MHz}, \mathrm{CDCl}_{3}\right)$ of $\mathbf{3 l}$

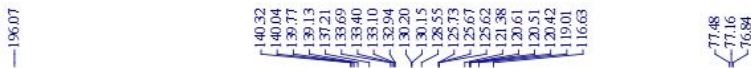

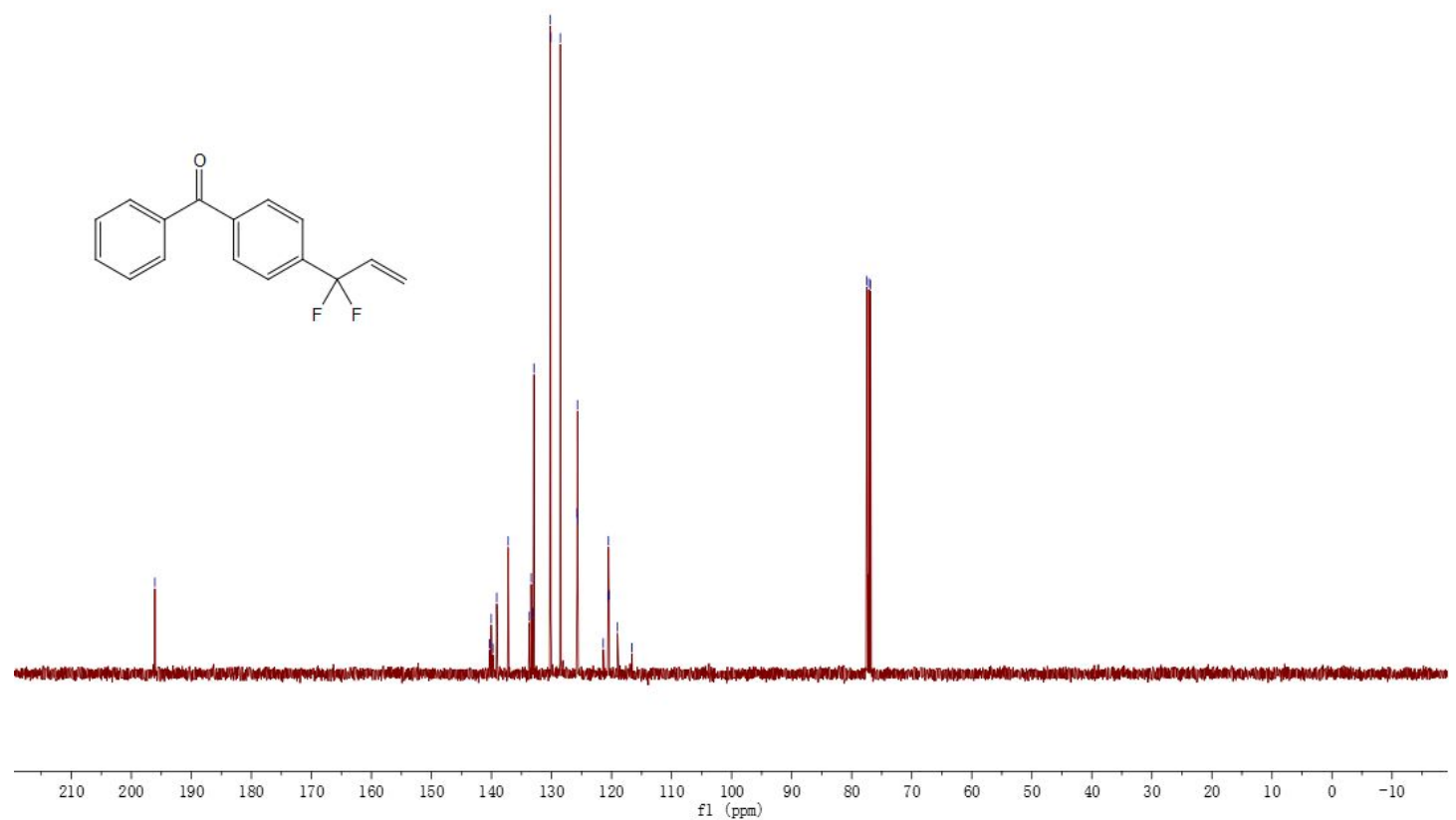


${ }^{1} \mathrm{H}\left(400 \mathrm{MHz}, \mathrm{CDCl}_{3}\right)$ of $\mathbf{3 m}$

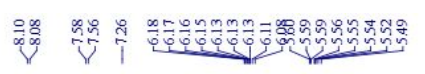

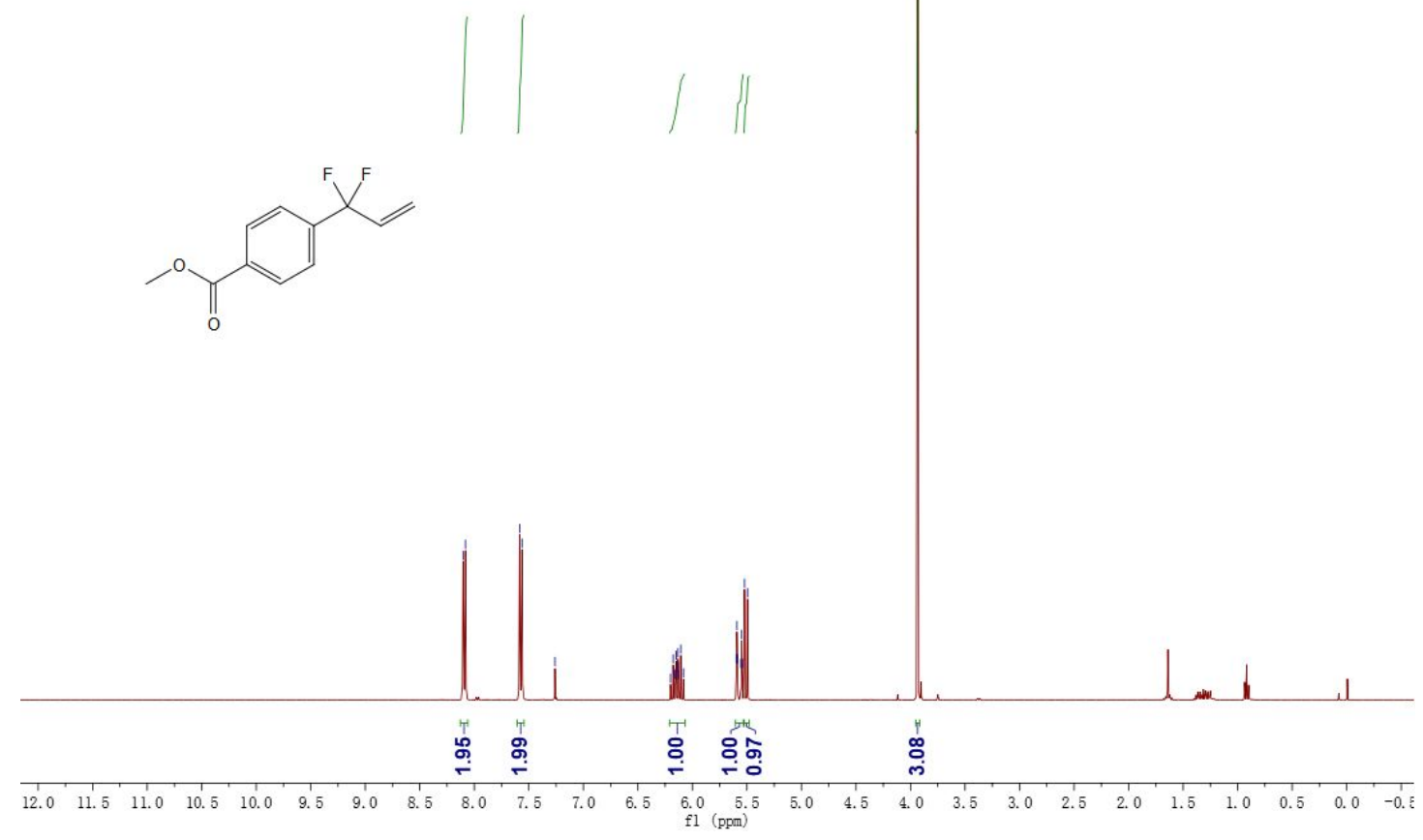

${ }^{19} \mathrm{~F}\left(376 \mathrm{MHz}, \mathrm{CDCl}_{3}\right)$ of $\mathbf{3 m}$

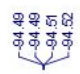

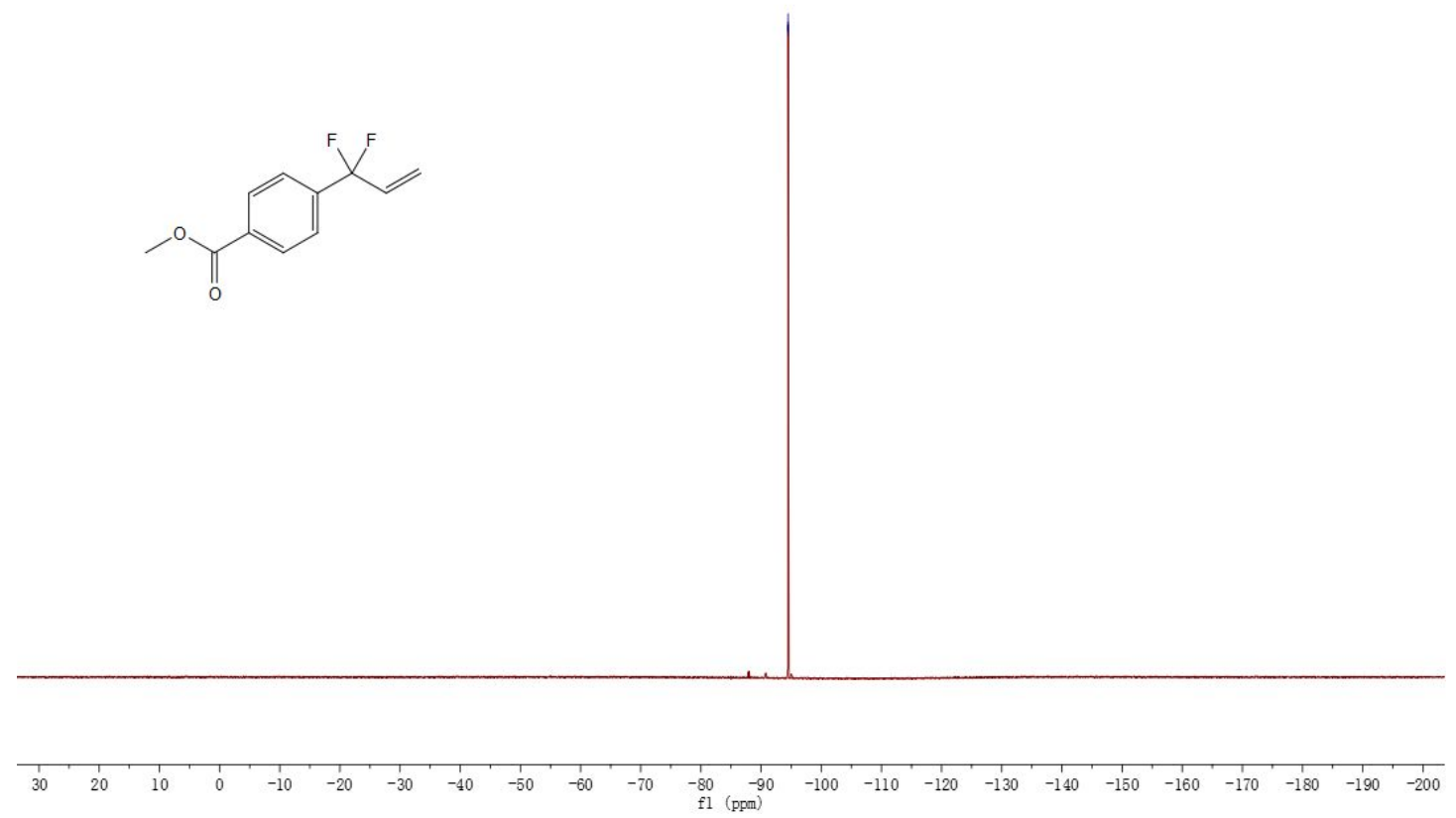


${ }^{13} \mathrm{C}\left\{{ }^{1} \mathrm{H}\right\}\left(101 \mathrm{MHz}, \mathrm{CDCl}_{3}\right)$ of $\mathbf{3 m}$

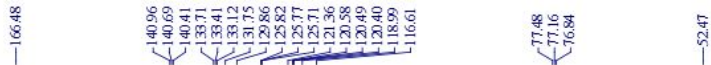

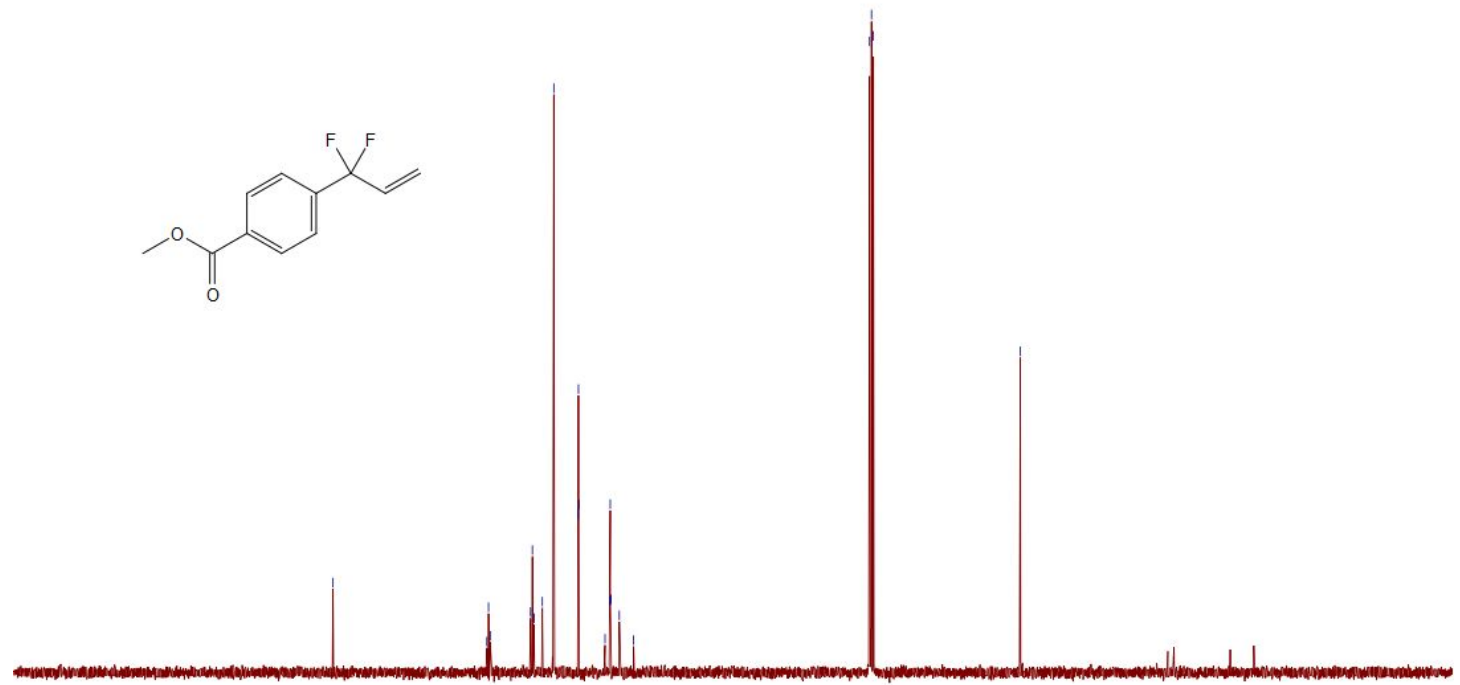

${ }^{1} \mathrm{H}\left(400 \mathrm{MHz}, \mathrm{CDCl}_{3}\right)$ of $\mathbf{3 n}$

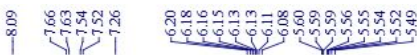
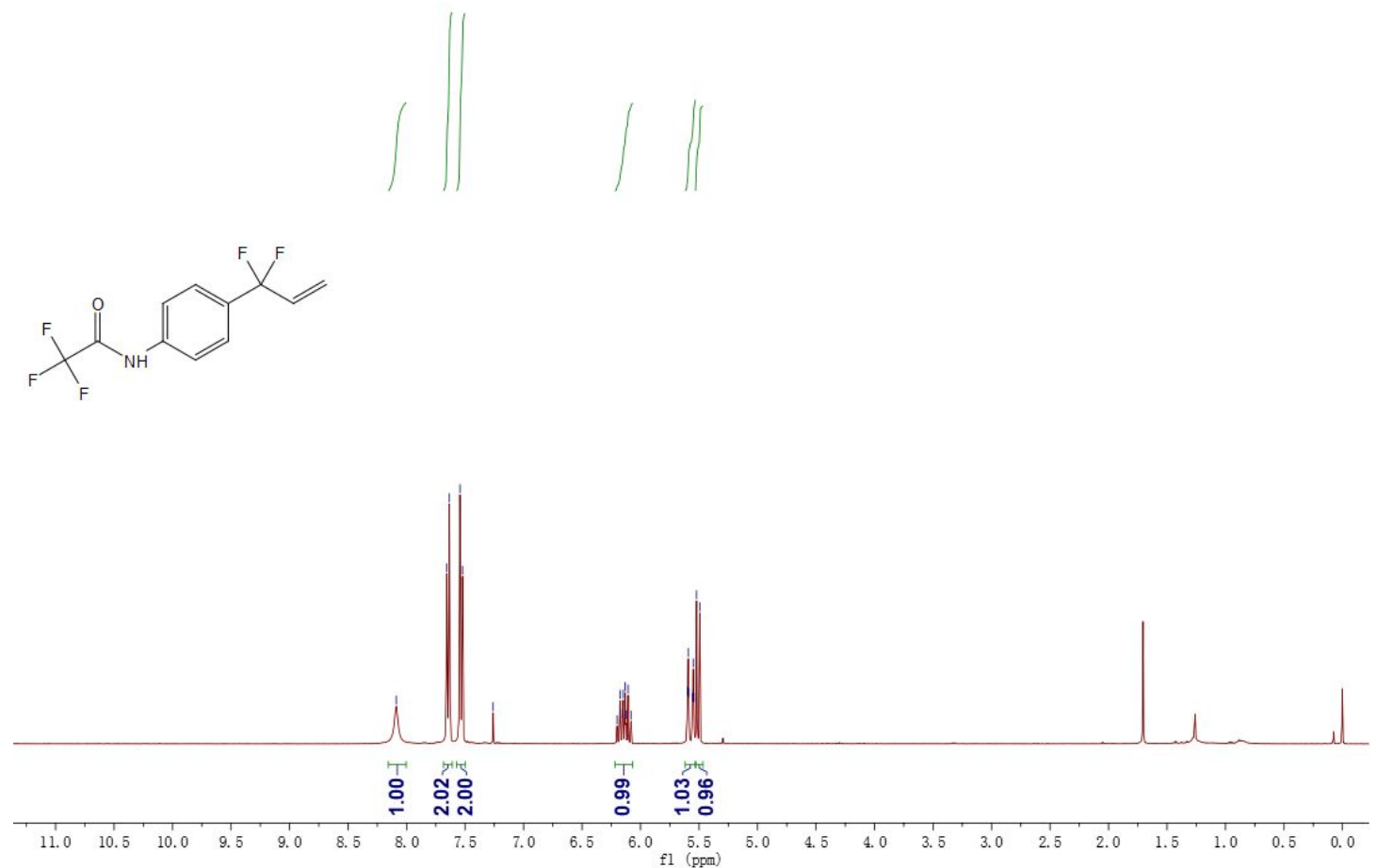
${ }^{19} \mathrm{~F}\left(377 \mathrm{MHz}, \mathrm{CDCl}_{3}\right)$ of $\mathbf{3 n}$

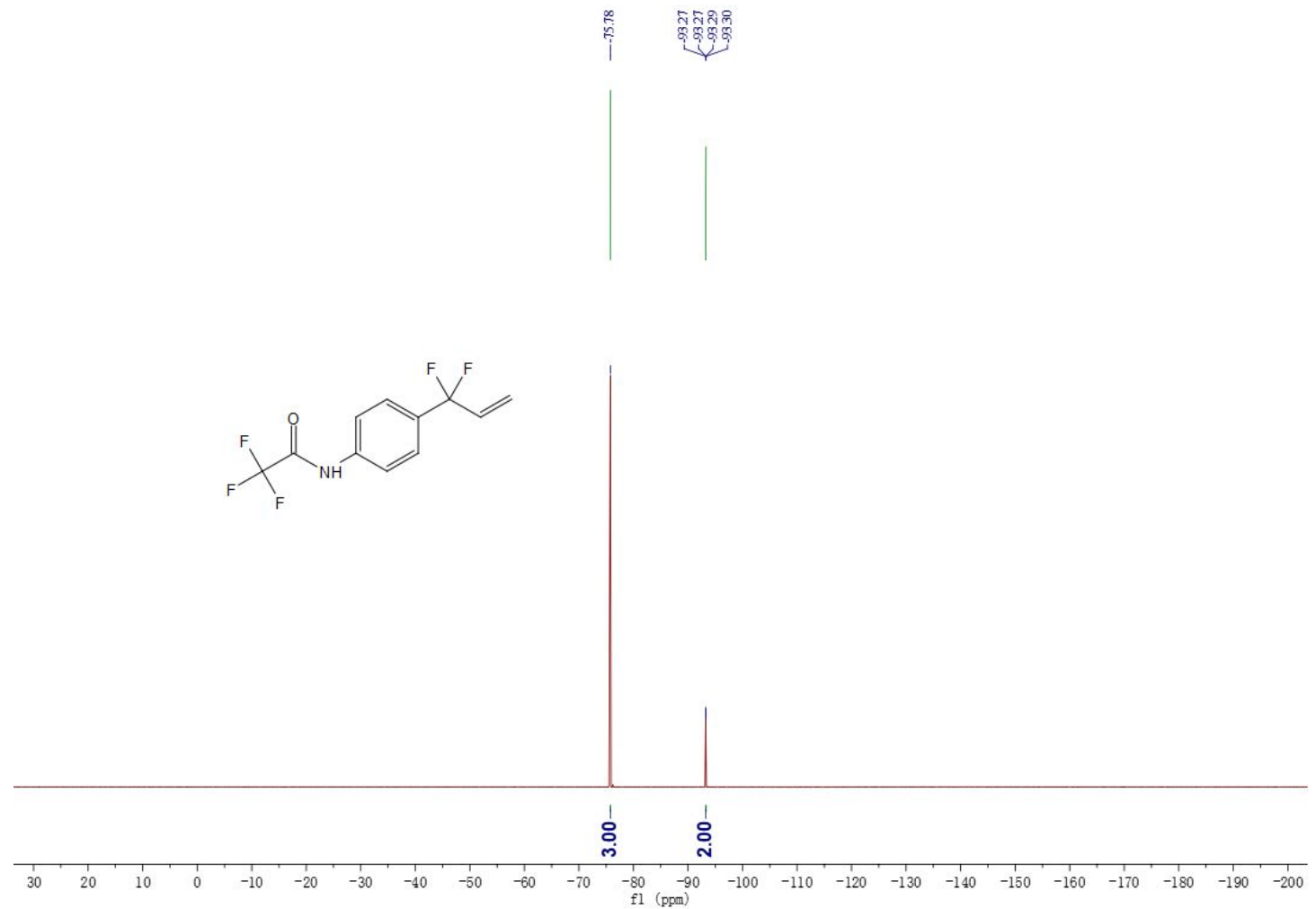

${ }^{13} \mathrm{C}\left\{{ }^{1} \mathrm{H}\right\}\left(101 \mathrm{MHz}, \mathrm{CDCl}_{3}\right)$ of $\mathbf{3 n}$

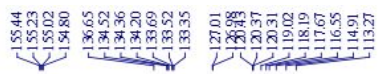
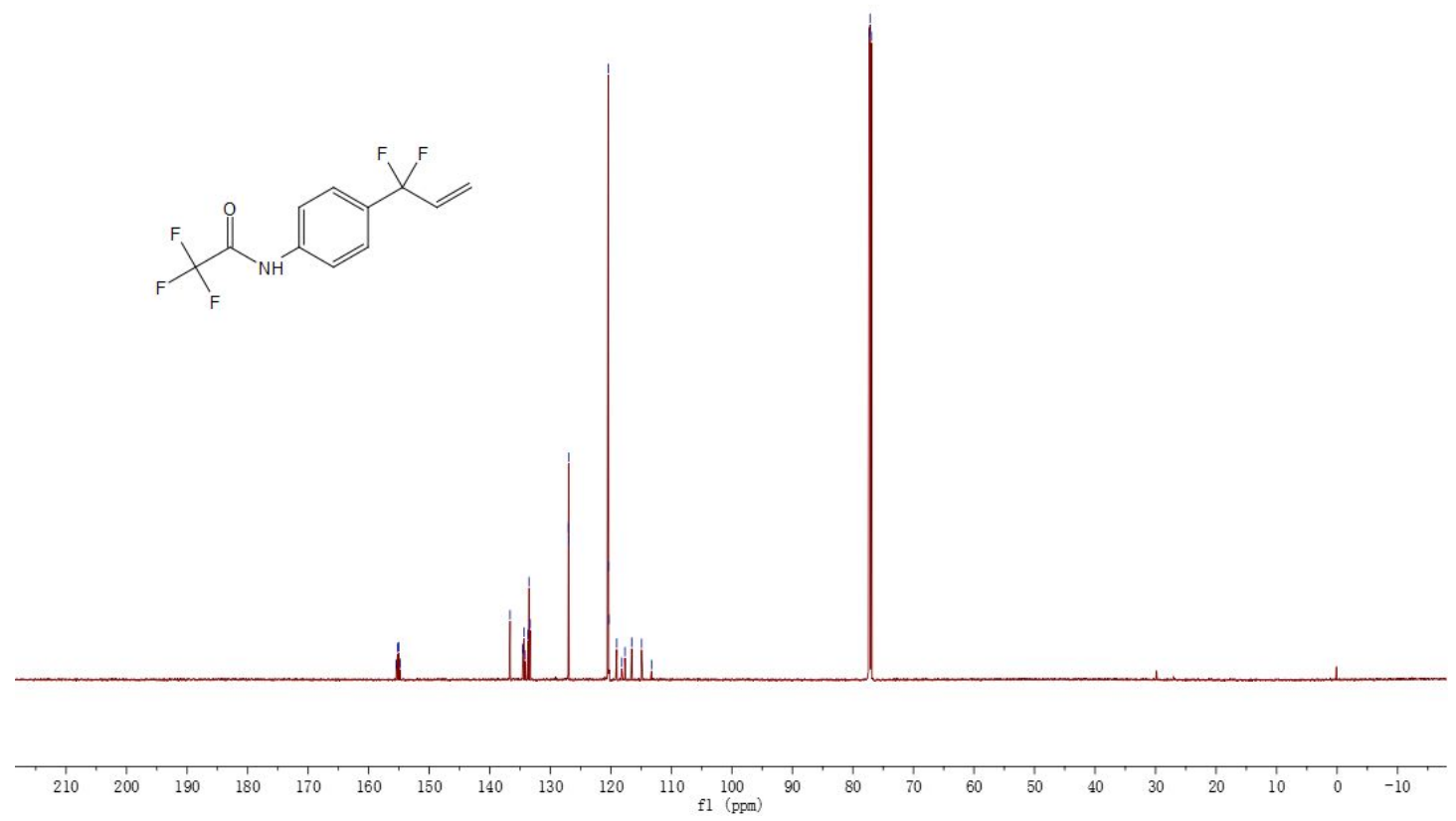
${ }^{1} \mathrm{H}\left(400 \mathrm{MHz}, \mathrm{CDCl}_{3}\right)$ of $\mathbf{3 o}$

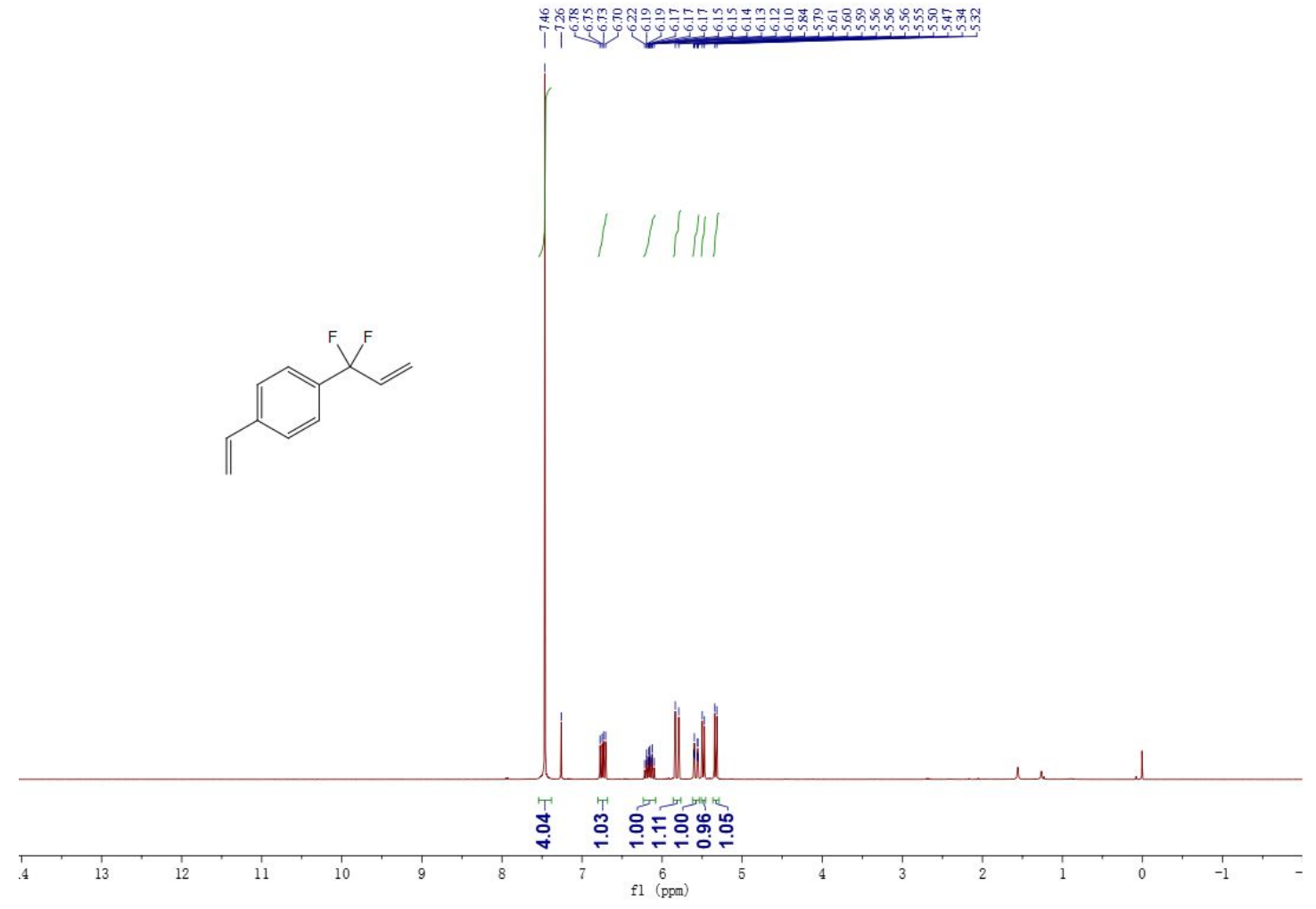

${ }^{19} \mathrm{~F}\left(376 \mathrm{MHz}, \mathrm{CDCl}_{3}\right)$ of $\mathbf{3 o}$

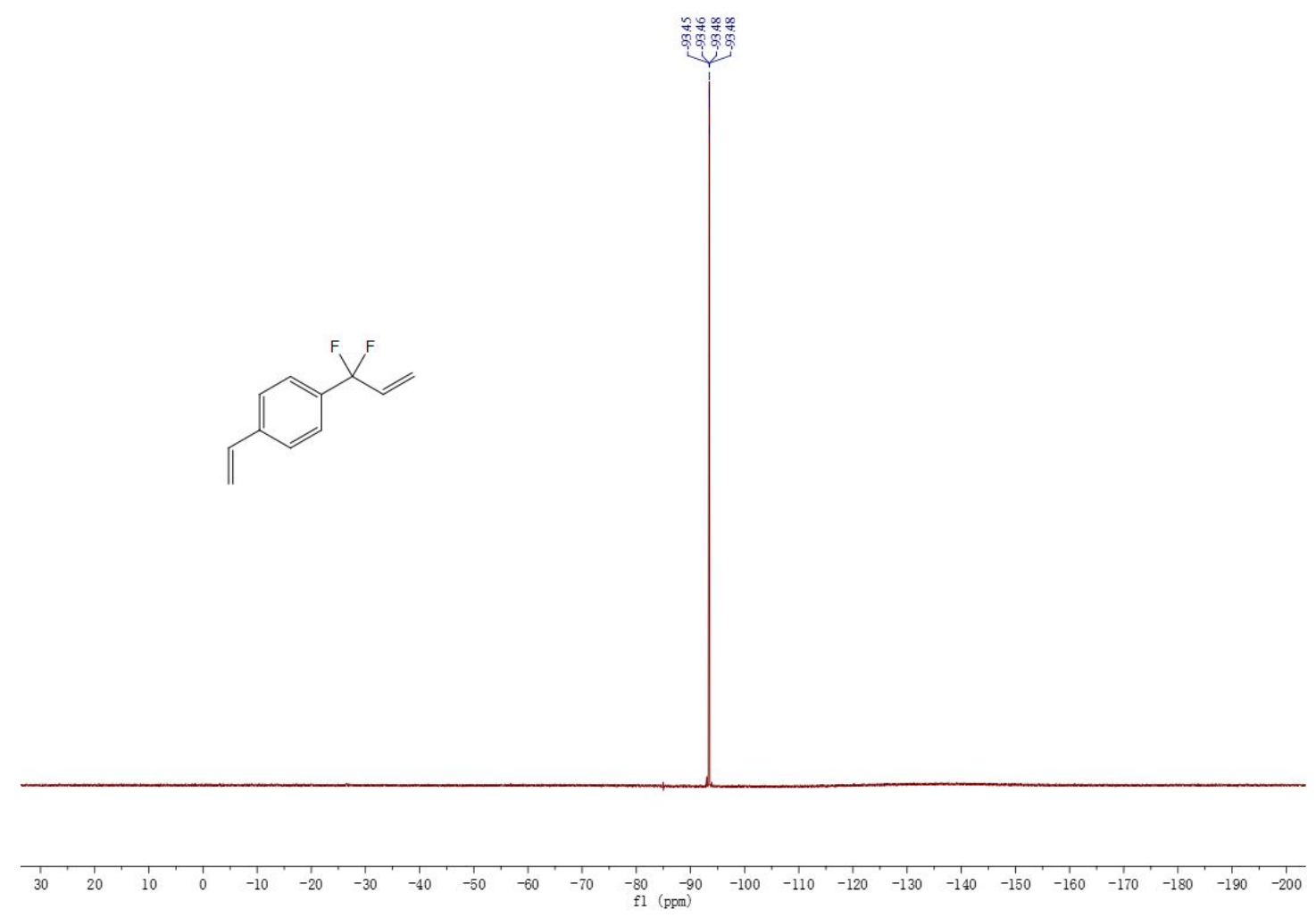


${ }^{13} \mathrm{C}\left\{{ }^{1} \mathrm{H}\right\}\left(101 \mathrm{MHz}, \mathrm{CDCl}_{3}\right)$ of $\mathbf{3 o}$

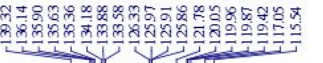

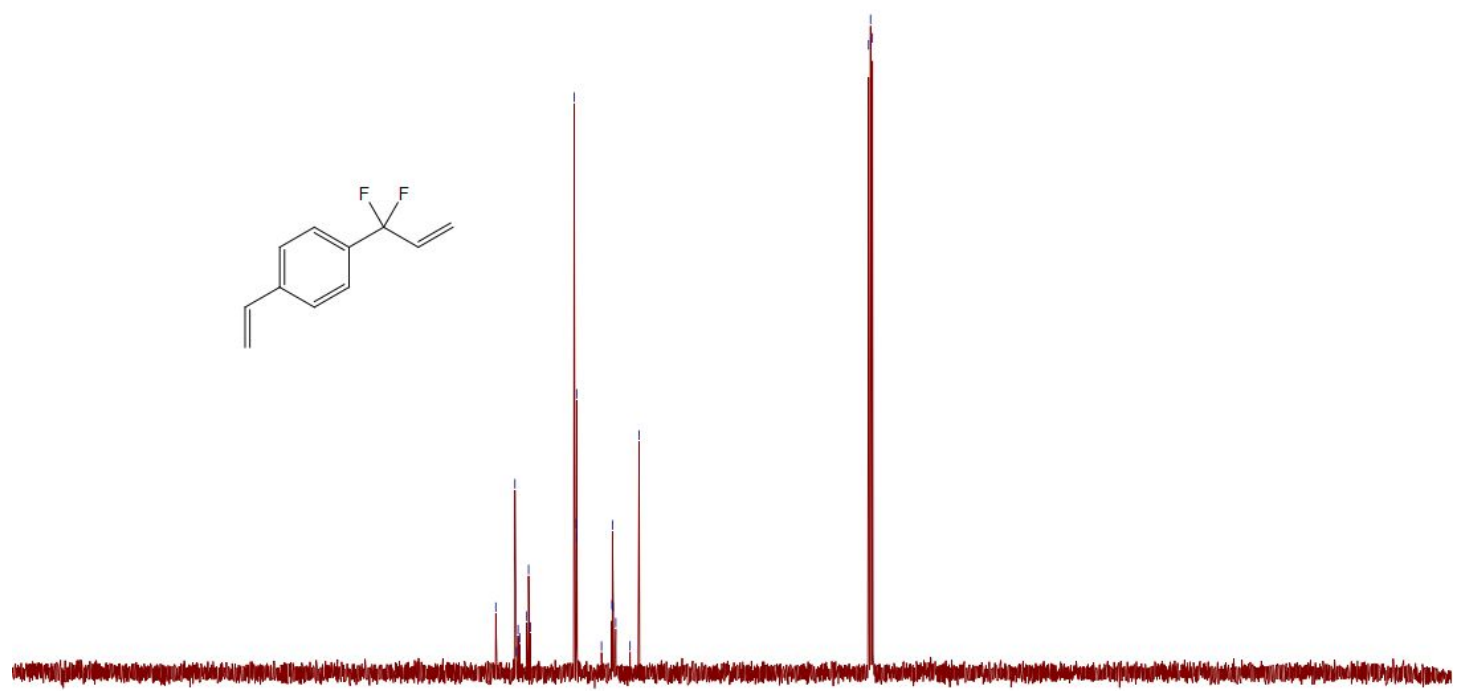

${ }^{1} \mathrm{H}\left(400 \mathrm{MHz}, \mathrm{CDCl}_{3}\right)$ of $\mathbf{3 p}$

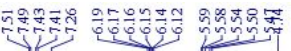
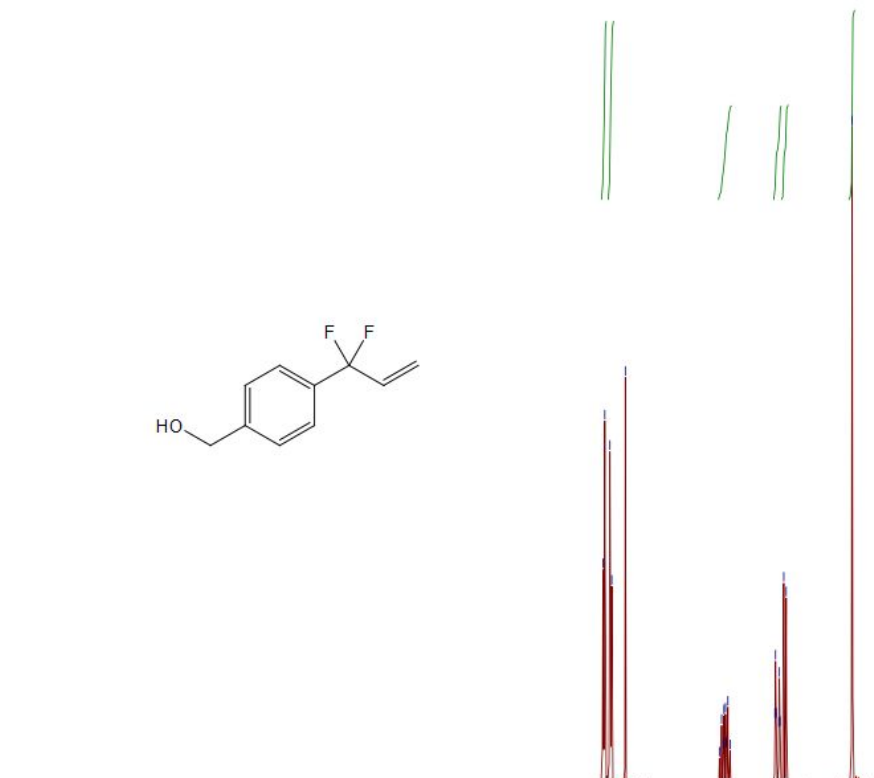

ธุ่สิ

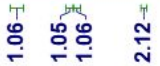

(bap) : 
${ }^{19} \mathrm{~F}\left(376 \mathrm{MHz}, \mathrm{CDCl}_{3}\right)$ of $\mathbf{3 p}$

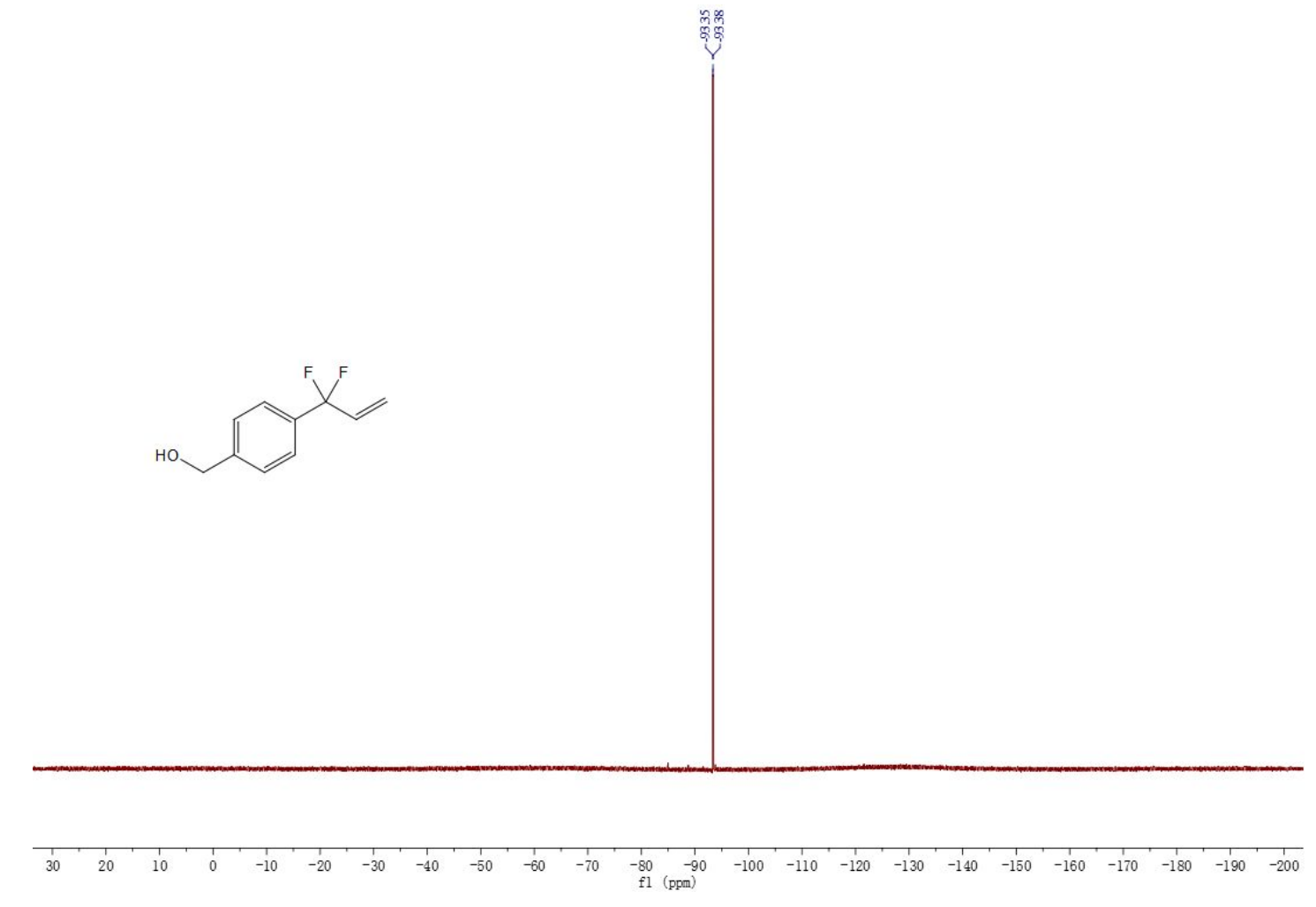

${ }^{13} \mathrm{C}\left\{{ }^{1} \mathrm{H}\right\}\left(101 \mathrm{MHz}, \mathrm{CDCl}_{3}\right)$ of $\mathbf{3 p}$
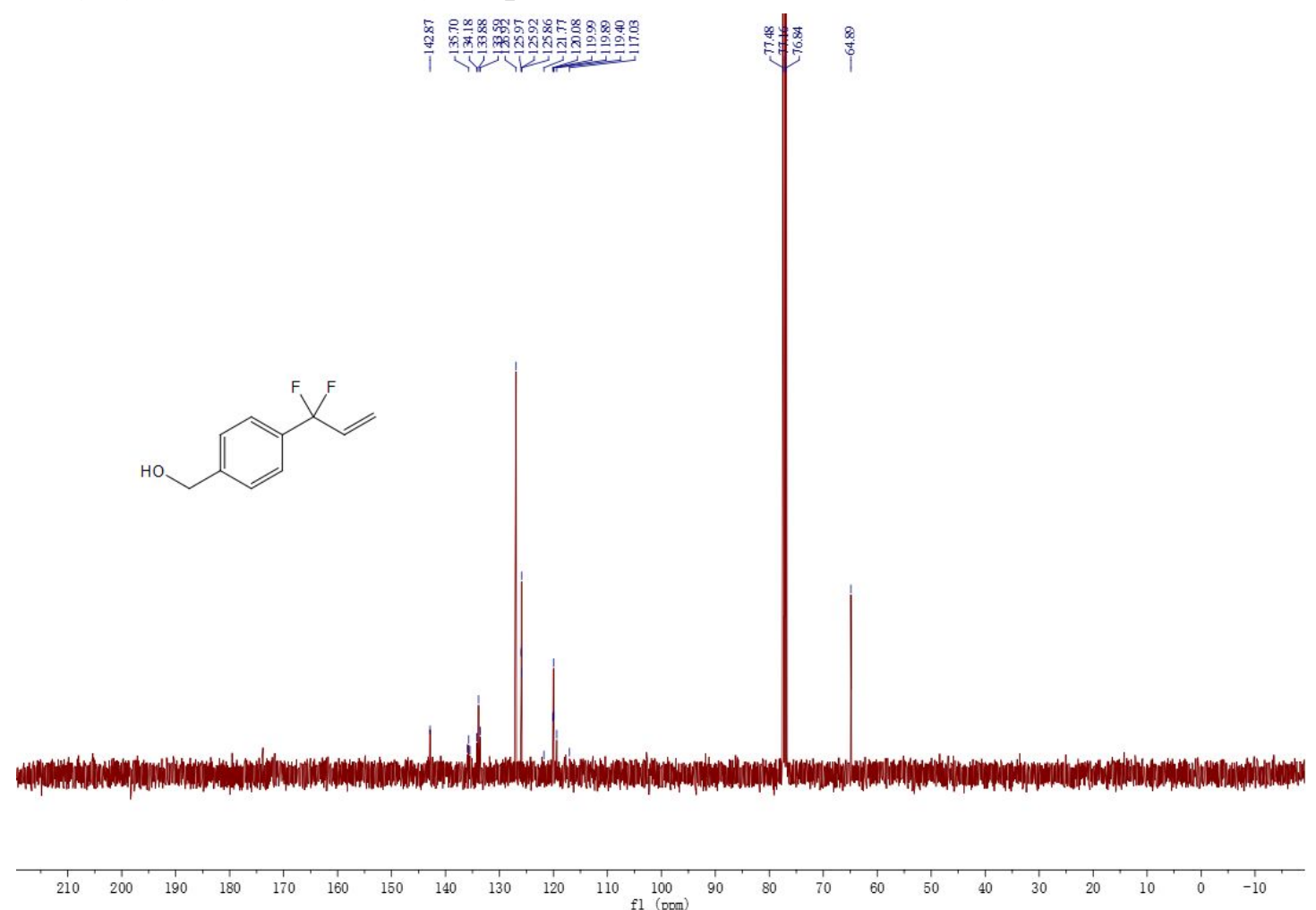
${ }^{1} \mathrm{H}\left(400 \mathrm{MHz}, \mathrm{CDCl}_{3}\right)$ of $\mathbf{3 q}$

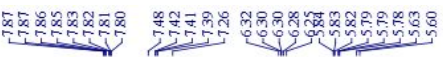

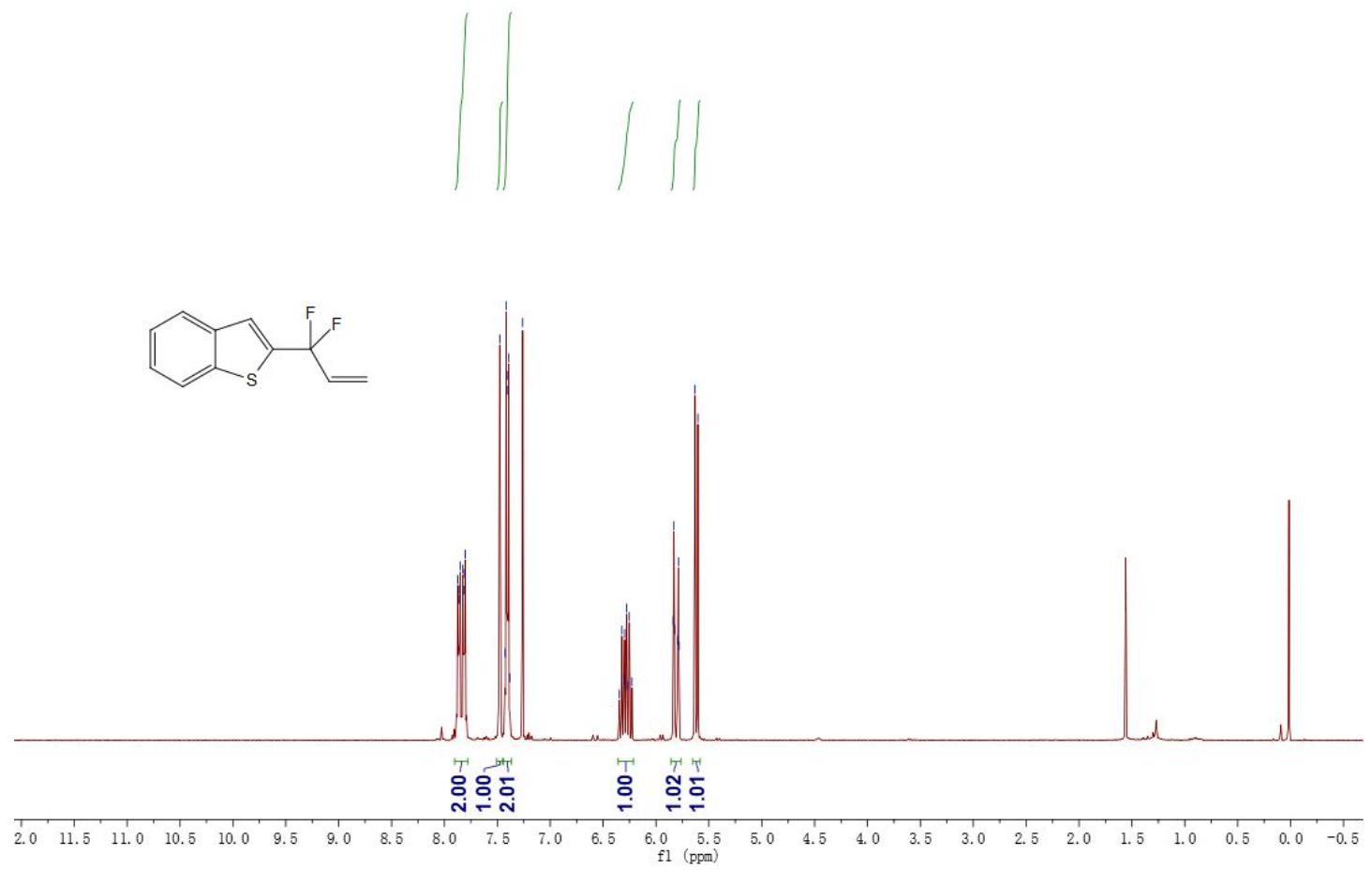

${ }^{19} \mathrm{~F}\left(376 \mathrm{MHz}, \mathrm{CDCl}_{3}\right)$ of $\mathbf{3 q}$

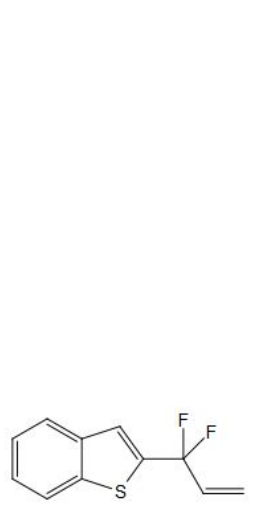

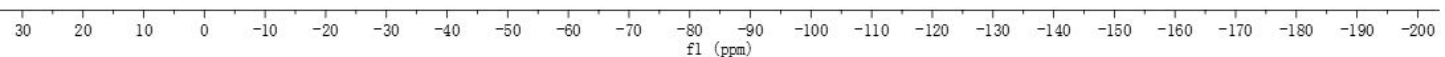


${ }^{13} \mathrm{C}\left\{{ }^{1} \mathrm{H}\right\}\left(101 \mathrm{MHz}, \mathrm{CDCl}_{3}\right)$ of $\mathbf{3 q}$

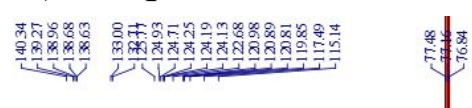
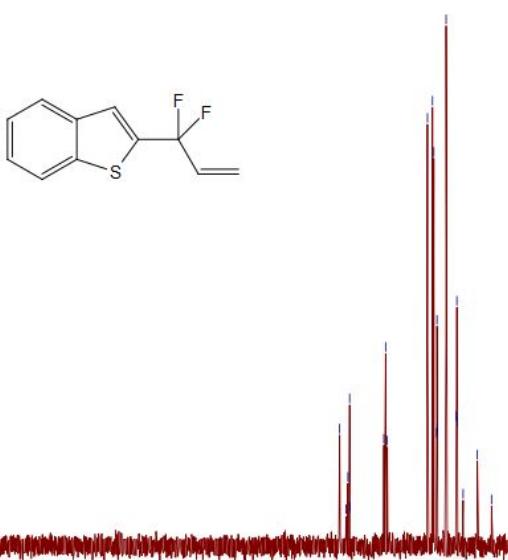

$\begin{array}{lllllll}10 & 200 & 190 & 180 & 170 & 160 & 150\end{array}$

$110 \underset{\mathrm{fl}}{100}(\mathrm{ppm})$

${ }^{1} \mathrm{H}\left(400 \mathrm{MHz}, \mathrm{CDCl}_{3}\right)$ of $\mathbf{3 r}$

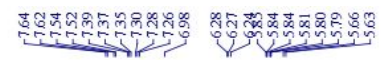
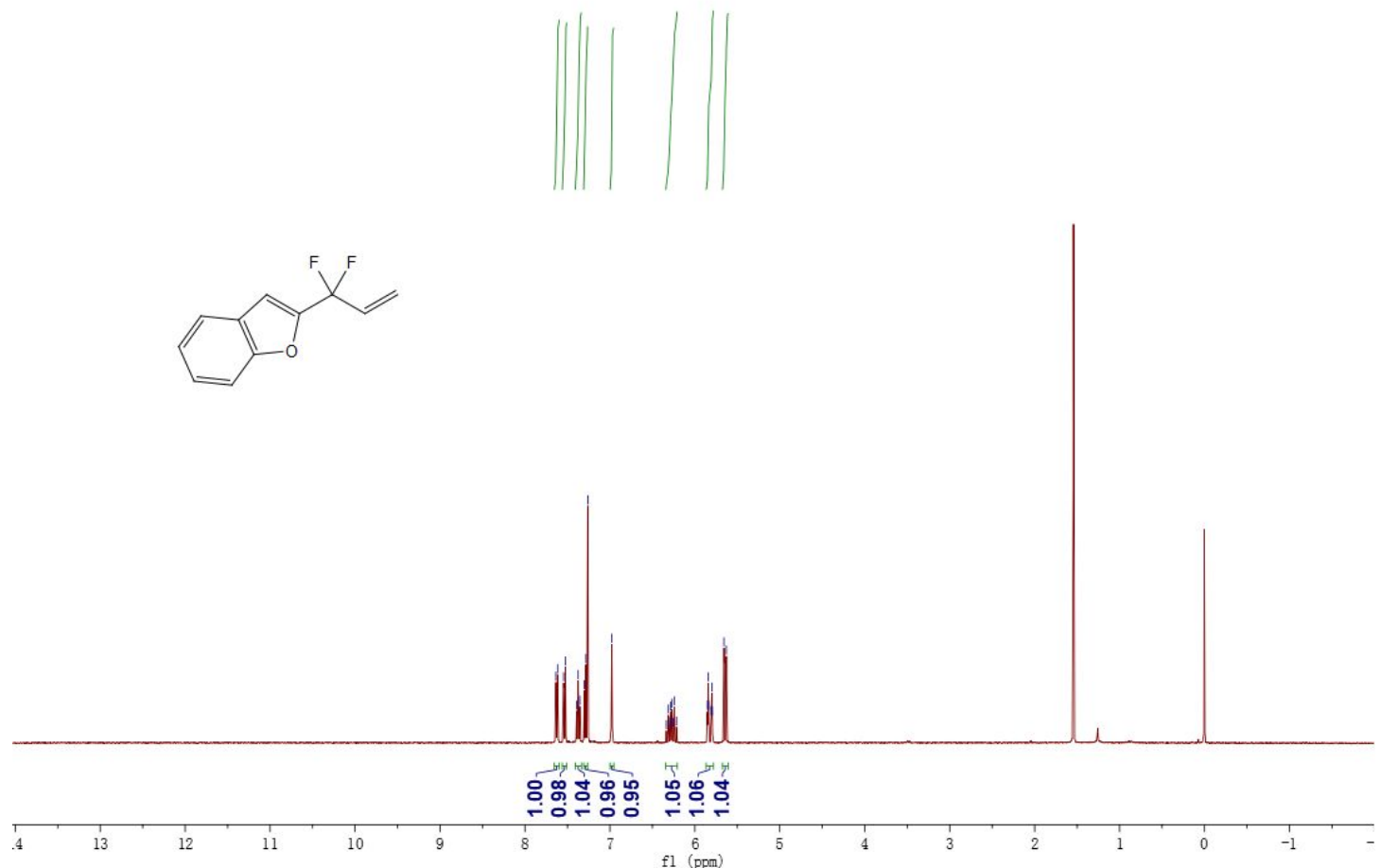
${ }^{19} \mathrm{~F}\left(376 \mathrm{MHz}, \mathrm{CDCl}_{3}\right)$ of $\mathbf{3 r}$
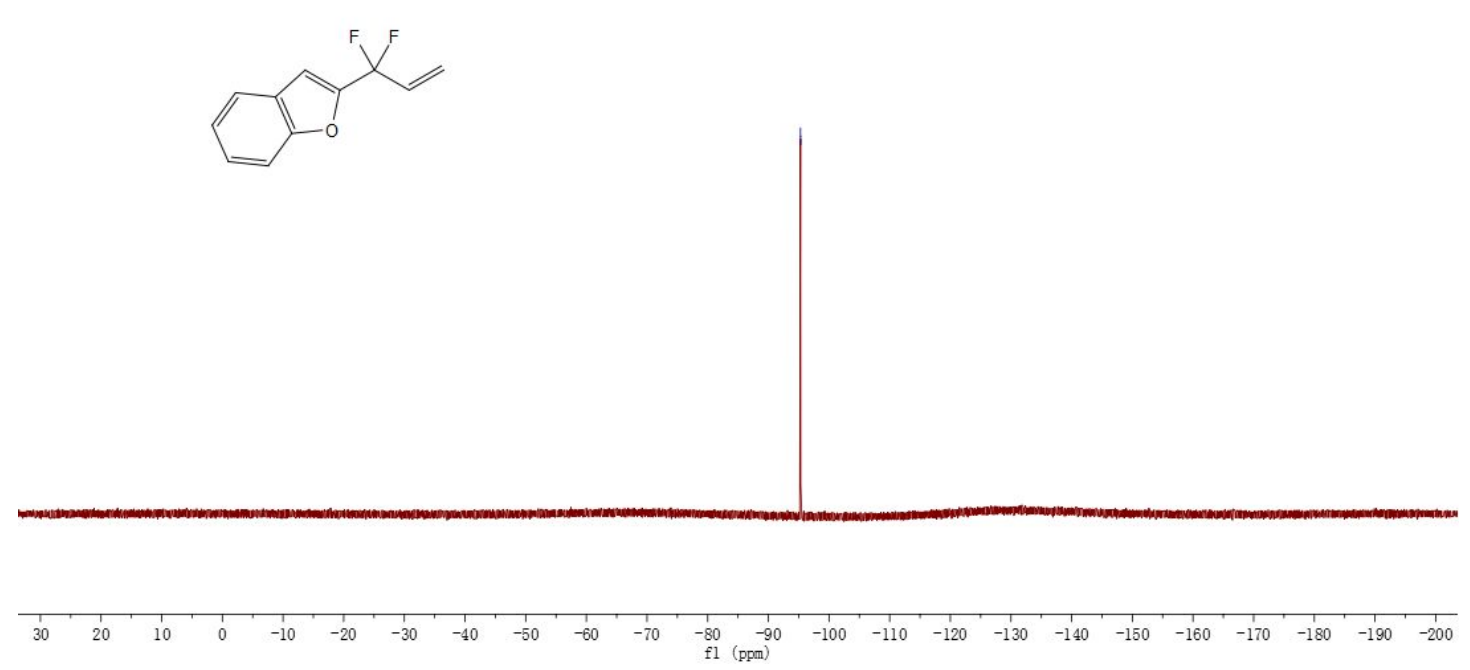

${ }^{13} \mathrm{C}\left\{{ }^{1} \mathrm{H}\right\}\left(176 \mathrm{MHz}, \mathrm{CDCl}_{3}\right)$ of $\mathbf{3 r}$
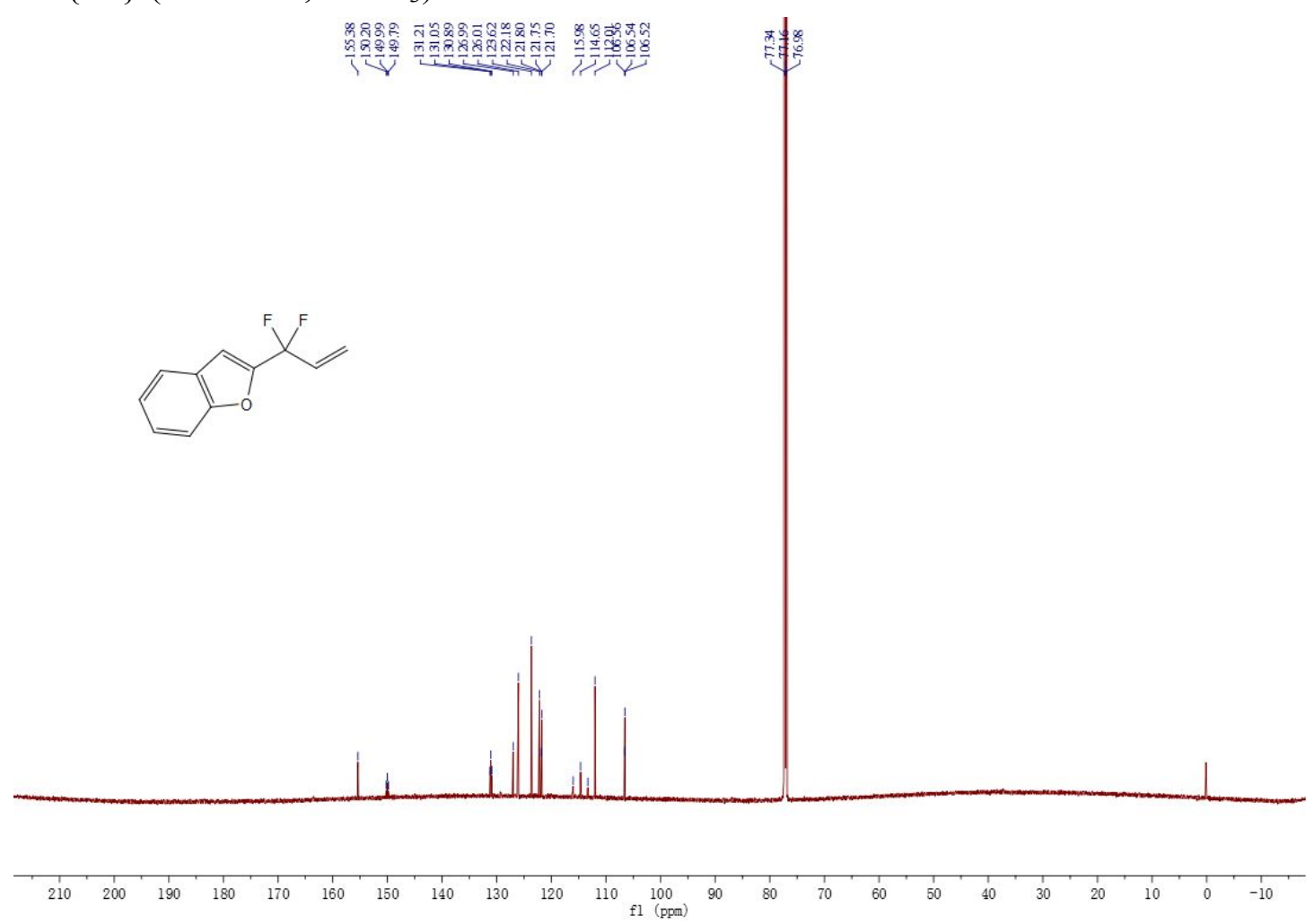
${ }^{1} \mathrm{H}\left(400 \mathrm{MHz}, \mathrm{CDCl}_{3}\right)$ of $\mathbf{3 s}$

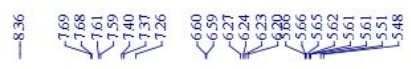

$\frac{8}{1}$

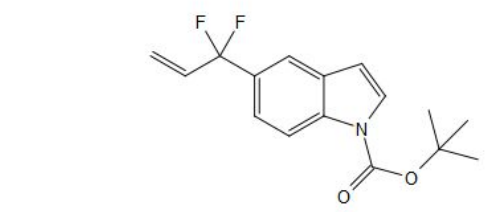

I H I I I

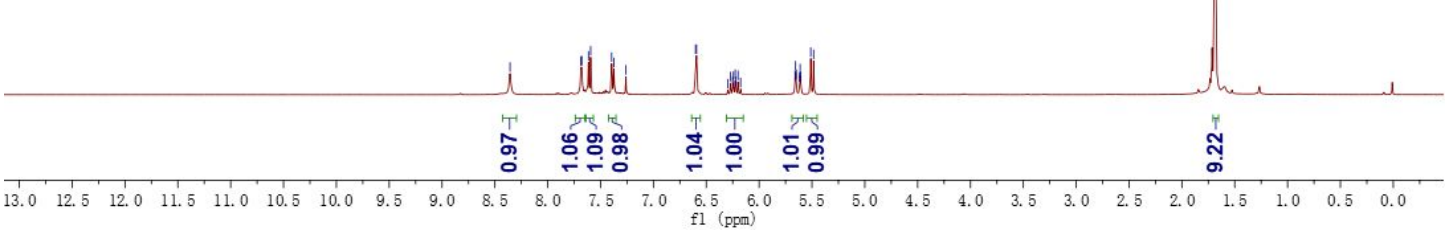

${ }^{19} \mathrm{~F}\left(376 \mathrm{MHz}, \mathrm{CDCl}_{3}\right)$ of $\mathbf{3 s}$
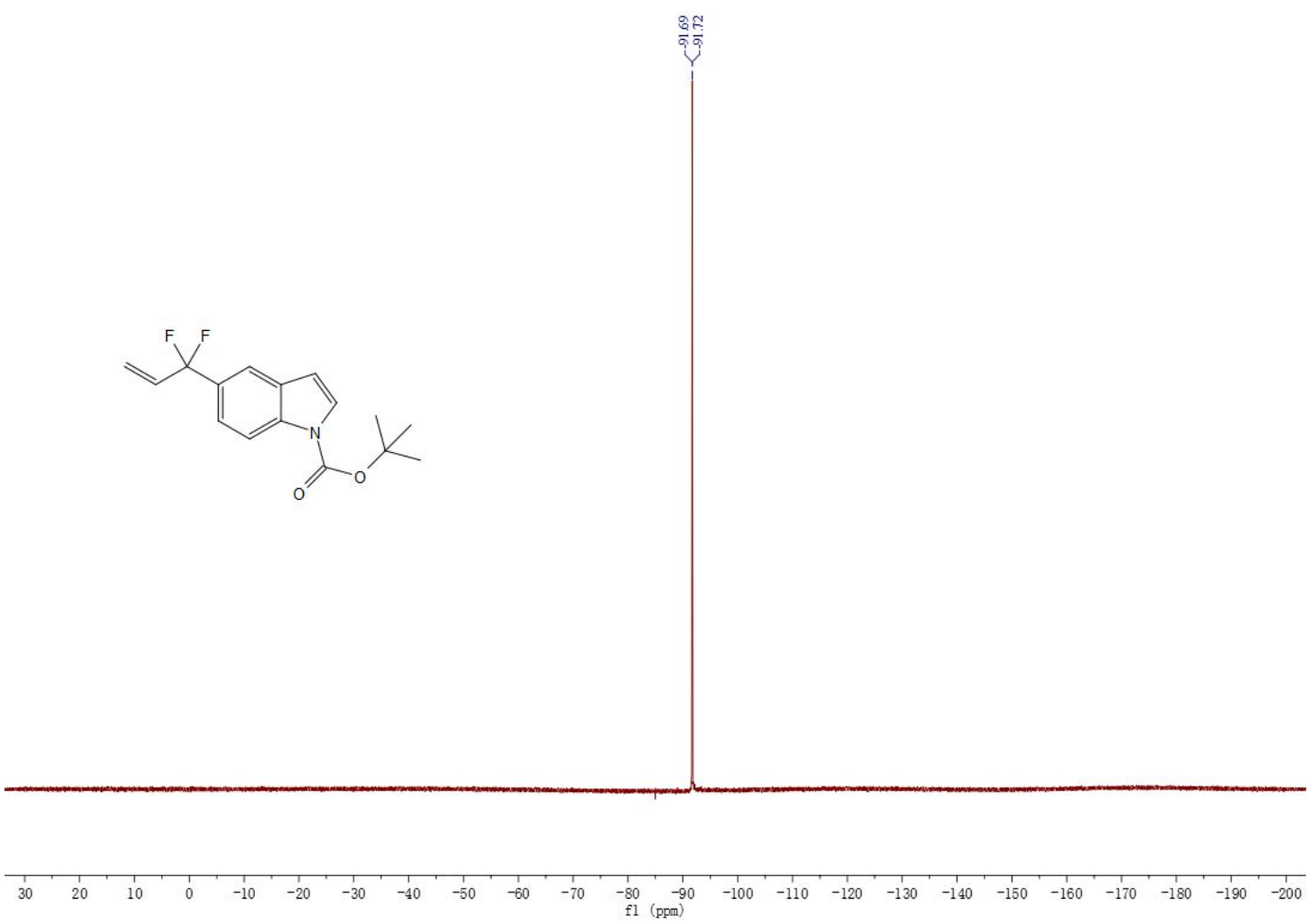

S57 
${ }^{13} \mathrm{C}\left\{{ }^{1} \mathrm{H}\right\}\left(101 \mathrm{MHz}, \mathrm{CDCl}_{3}\right)$ of $\mathbf{3 s}$

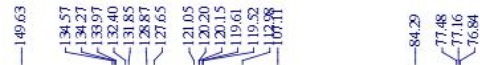
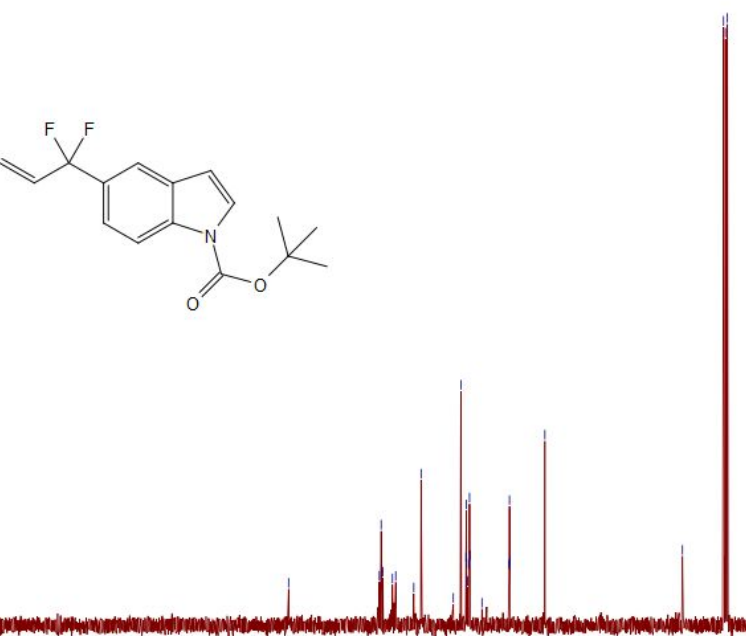

$\begin{array}{lllllll}210 & 200 & 190 & 180 & 170 & 160 & 150\end{array}$

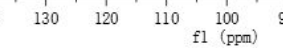

${ }^{1} \mathrm{H}\left(400 \mathrm{MHz}, \mathrm{CDCl}_{3}\right)$ of $\mathbf{3 t}$

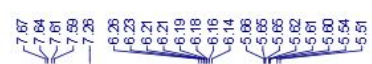
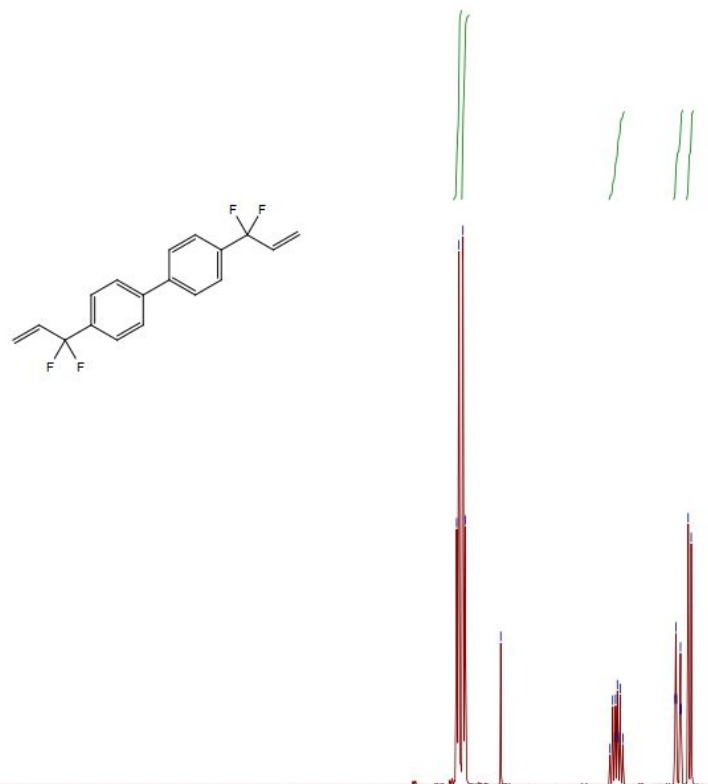

垔

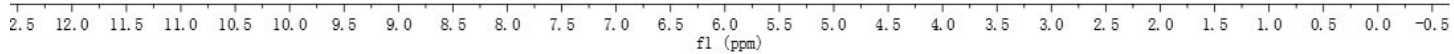


${ }^{19} \mathrm{~F}\left(376 \mathrm{MHz}, \mathrm{CDCl}_{3}\right)$ of $\mathbf{3 t}$

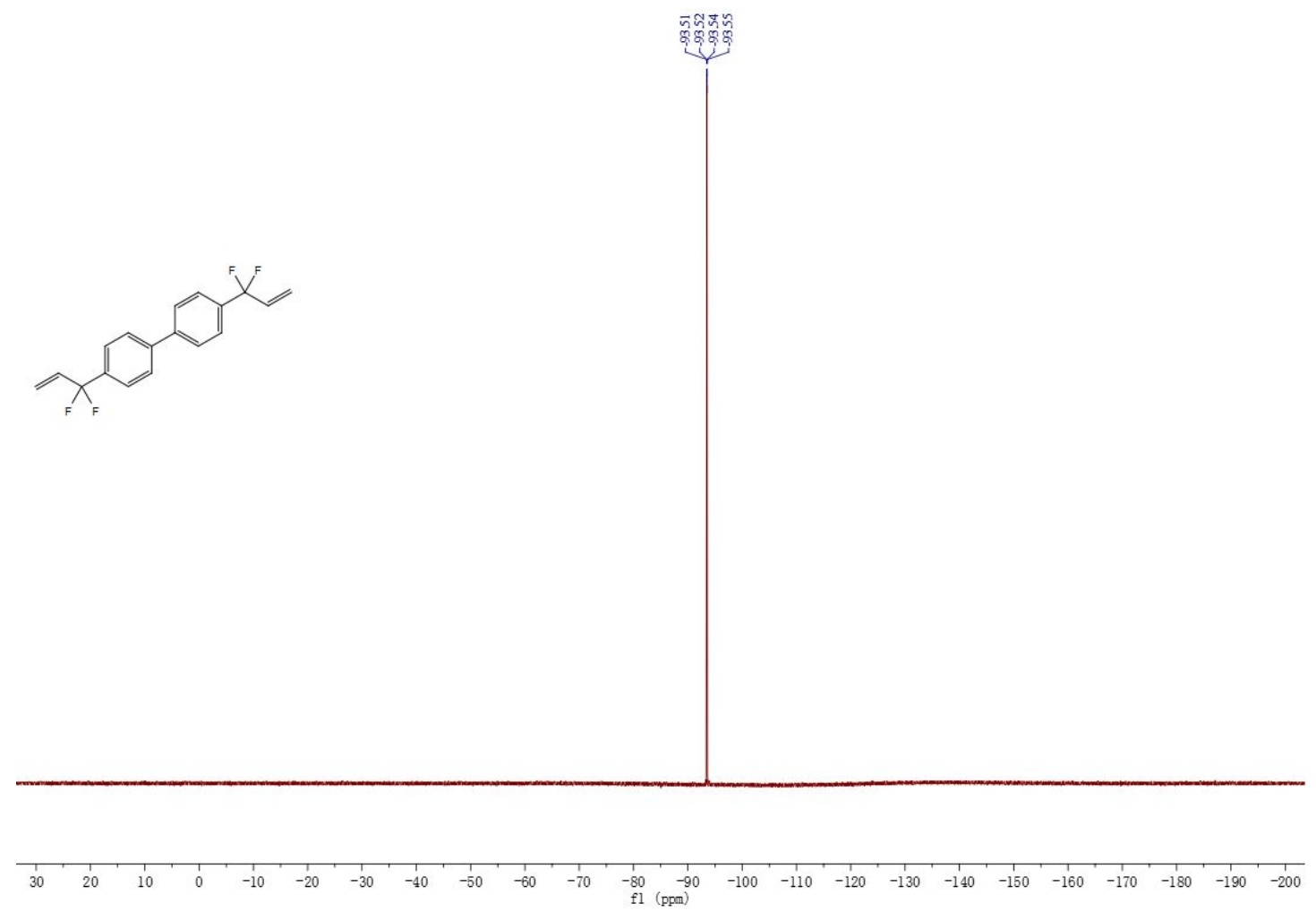

${ }^{13} \mathrm{C}\left\{{ }^{1} \mathrm{H}\right\}\left(101 \mathrm{MHz}, \mathrm{CDCl}_{3}\right)$ of $\mathbf{3 t}$

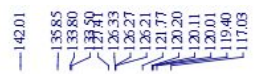

总오융

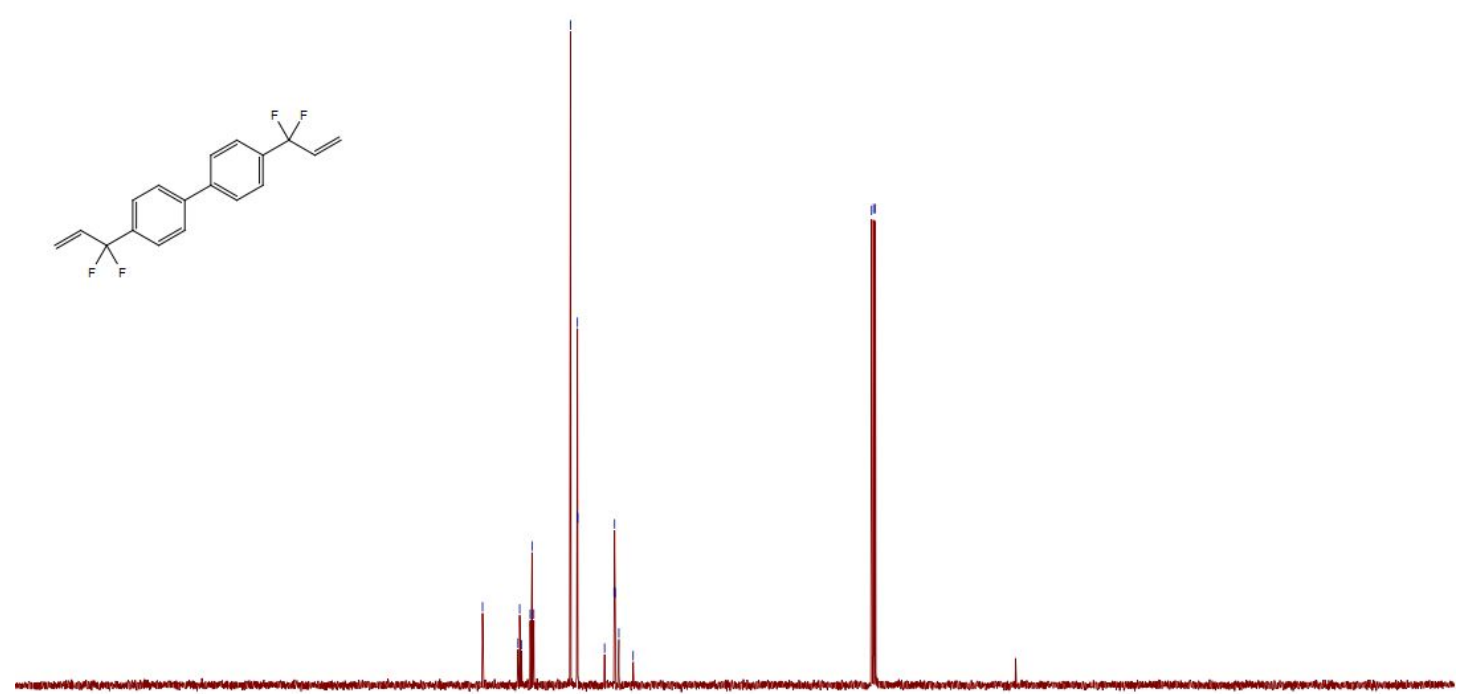

$\begin{array}{lllllllllllllllllllllllll}1 & 1 & 200 & 190 & 180 & 170 & 160 & 150 & 140 & 130 & 120 & 110 & 100 & 10 & 80 & 70 & 60 & 50 & 40 & 30 & 20 & 10 & 0 & -10\end{array}$ 
${ }^{1} \mathrm{H}\left(400 \mathrm{MHz}, \mathrm{CDCl}_{3}\right)$ of $\mathbf{3 u}$

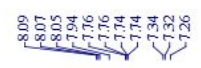
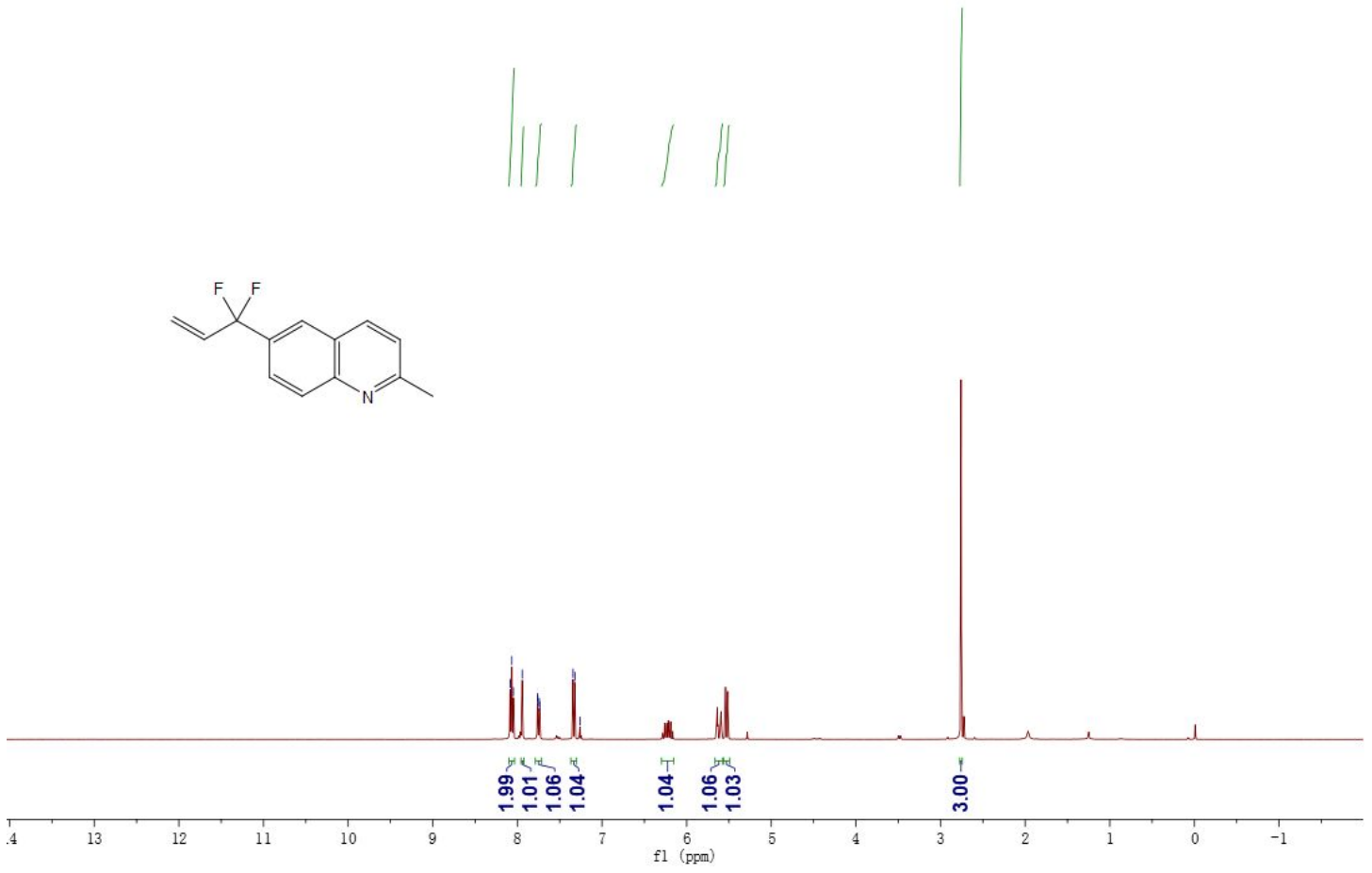

${ }^{19} \mathrm{~F}\left(376 \mathrm{MHz}, \mathrm{CDCl}_{3}\right)$ of $\mathbf{3 u}$

题绐
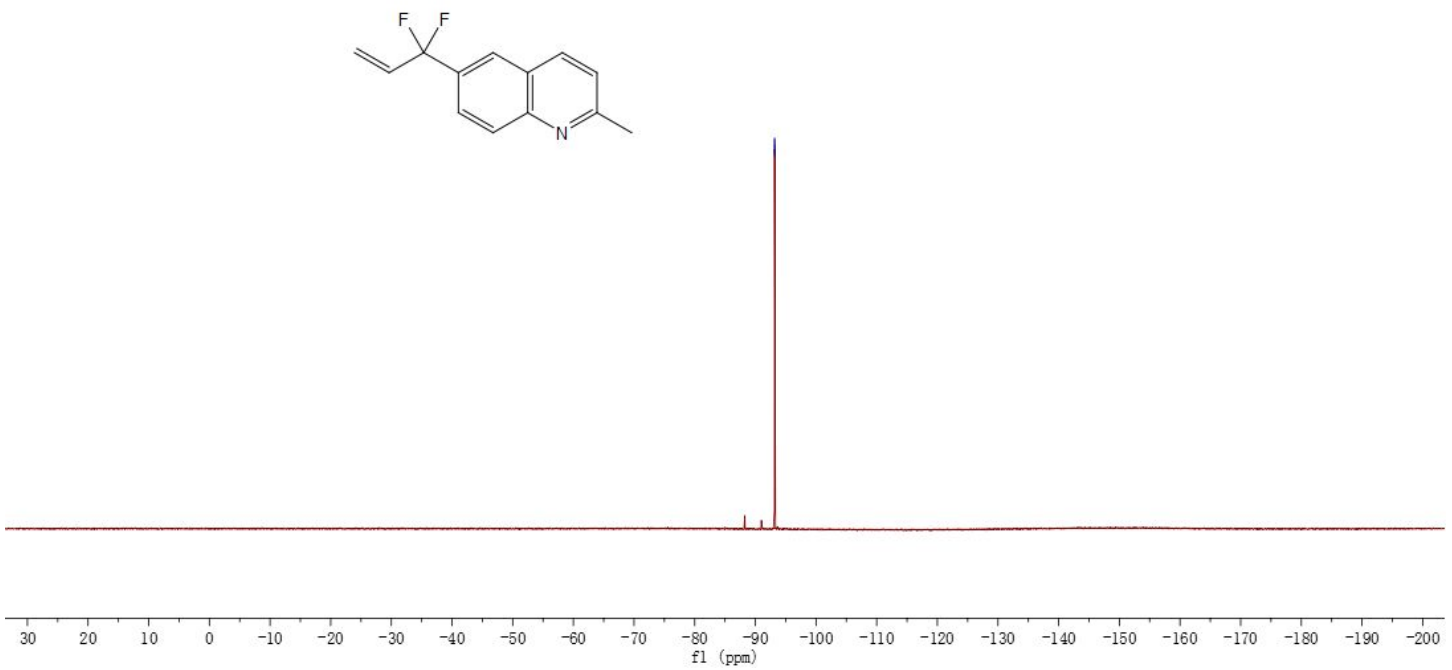

S60 
${ }^{13} \mathrm{C}\left\{{ }^{1} \mathrm{H}\right\}\left(101 \mathrm{MHz}, \mathrm{CDCl}_{3}\right)$ of $\mathbf{3 u}$

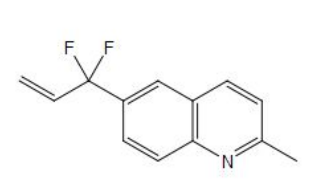

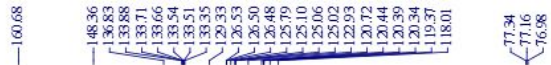

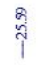

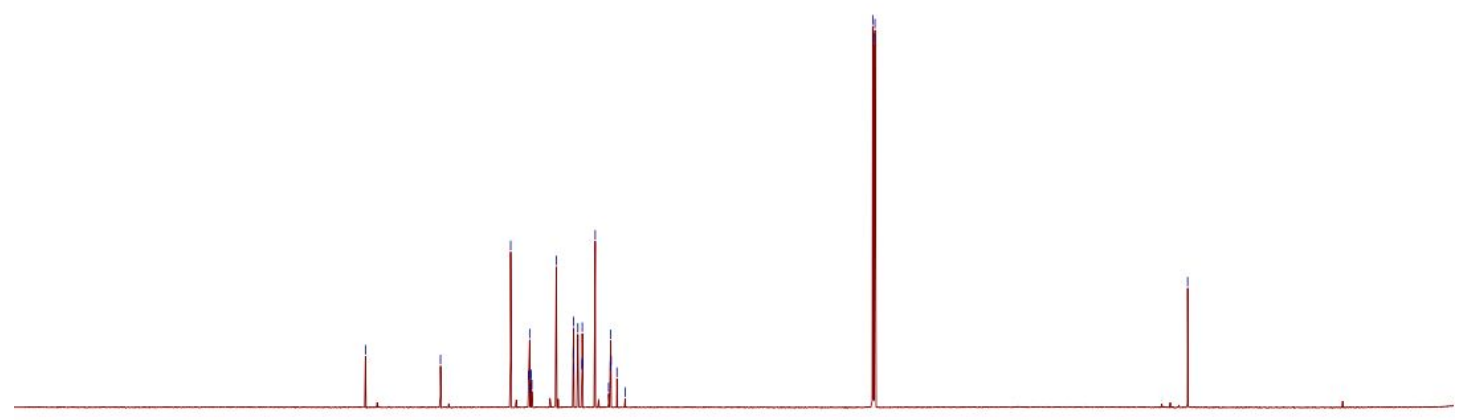

$210 \quad 200 \quad 190$

$\begin{array}{lllllll}190 & 180 & 170 & 160 & 150 & 140\end{array}$

$\begin{array}{llll}130 & 120 & 110 & 100 \\ \mathrm{fl}(\mathrm{ppm}) & \end{array}$

${ }^{1} \mathrm{H}\left(400 \mathrm{MHz}, \mathrm{CDCl}_{3}\right)$ of $\mathbf{3 v}$

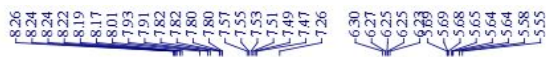
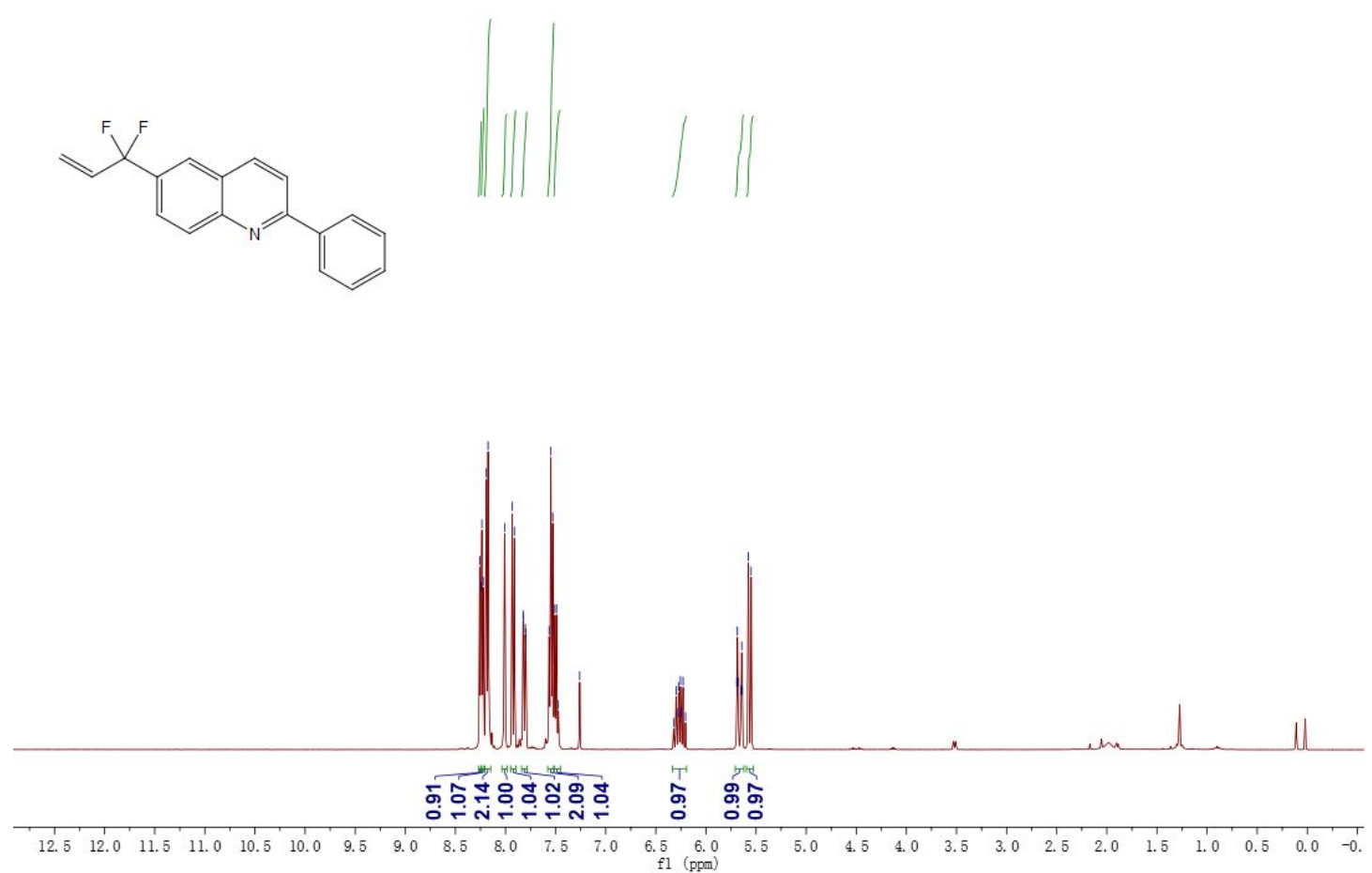
${ }^{19} \mathrm{~F}\left(376 \mathrm{MHz}, \mathrm{CDCl}_{3}\right)$ of $\mathbf{3 v}$

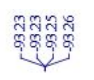
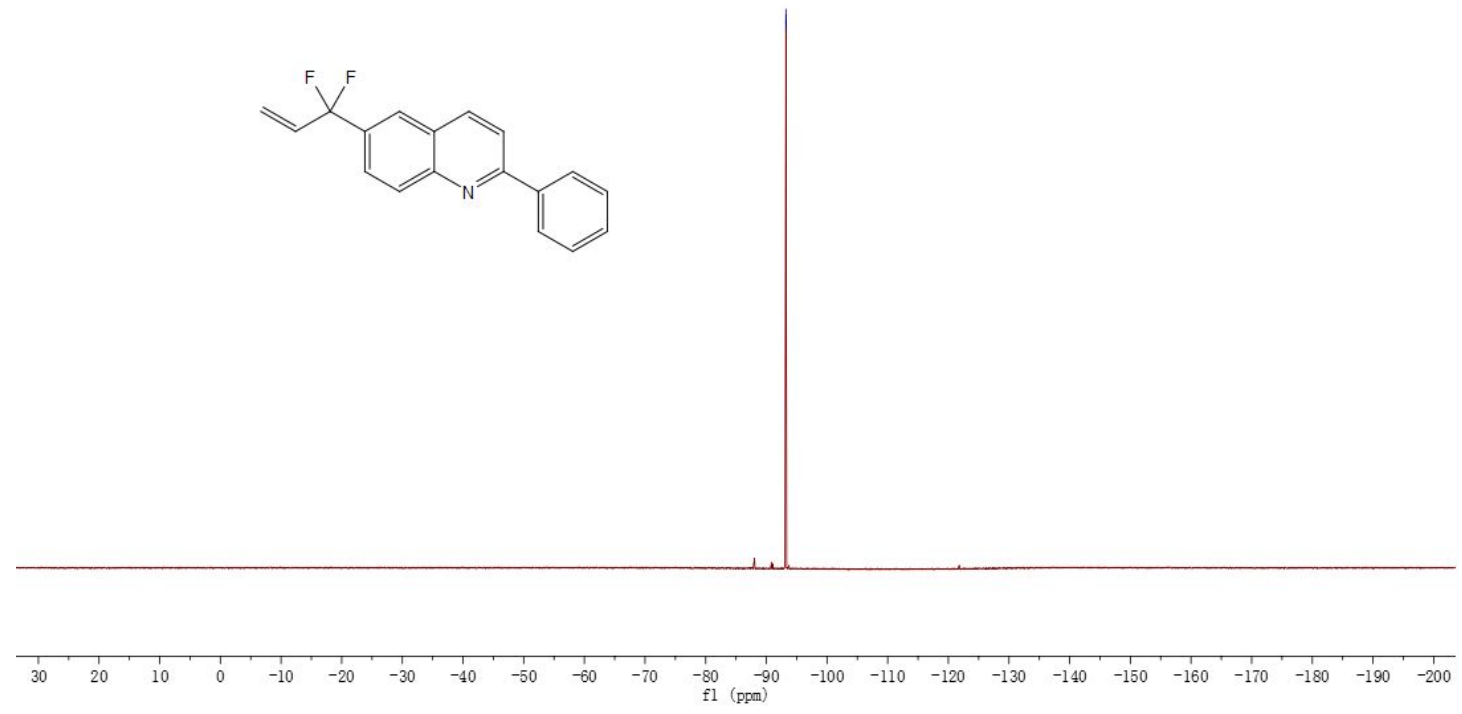

${ }^{13} \mathrm{C}\left\{{ }^{1} \mathrm{H}\right\}\left(101 \mathrm{MHz}, \mathrm{CDCl}_{3}\right)$ of $\mathbf{3 v}$

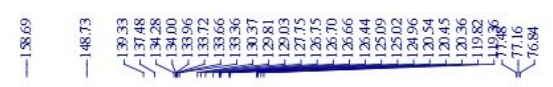

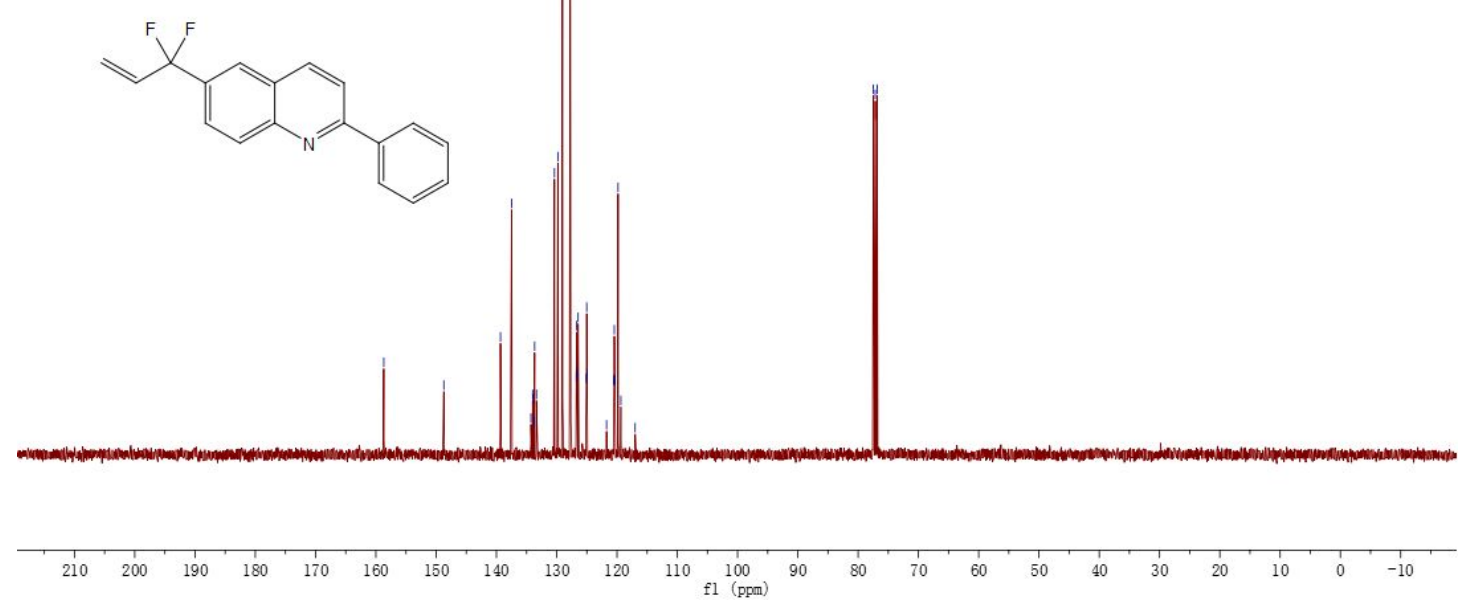

S62 
${ }^{1} \mathrm{H}\left(400 \mathrm{MHz}, \mathrm{CDCl}_{3}\right)$ of $\mathbf{3 w}$

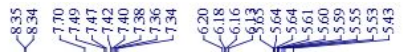

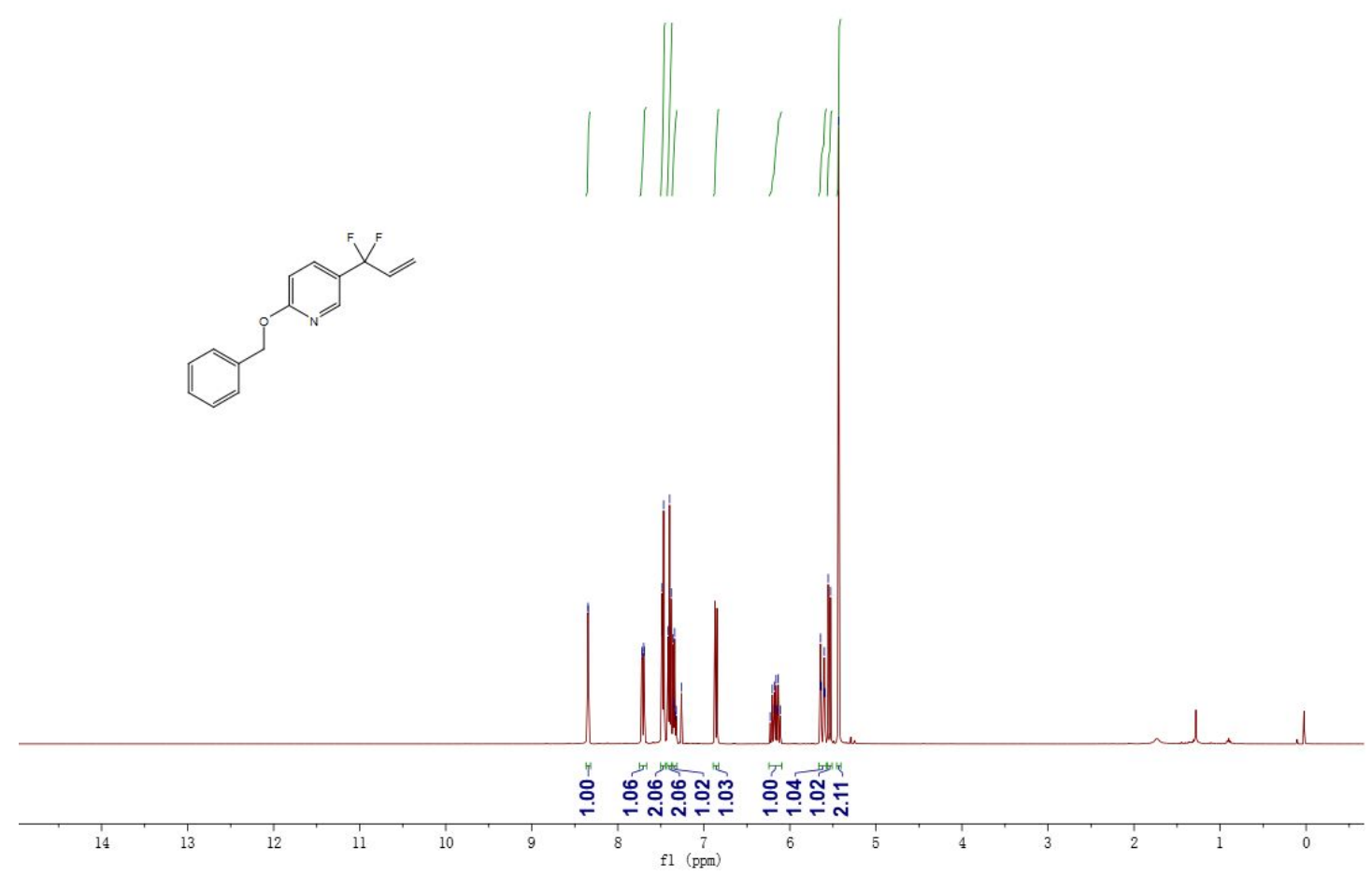

${ }^{19} \mathrm{~F}\left(377 \mathrm{MHz}, \mathrm{CDCl}_{3}\right)$ of $\mathbf{3 w}$

范畗

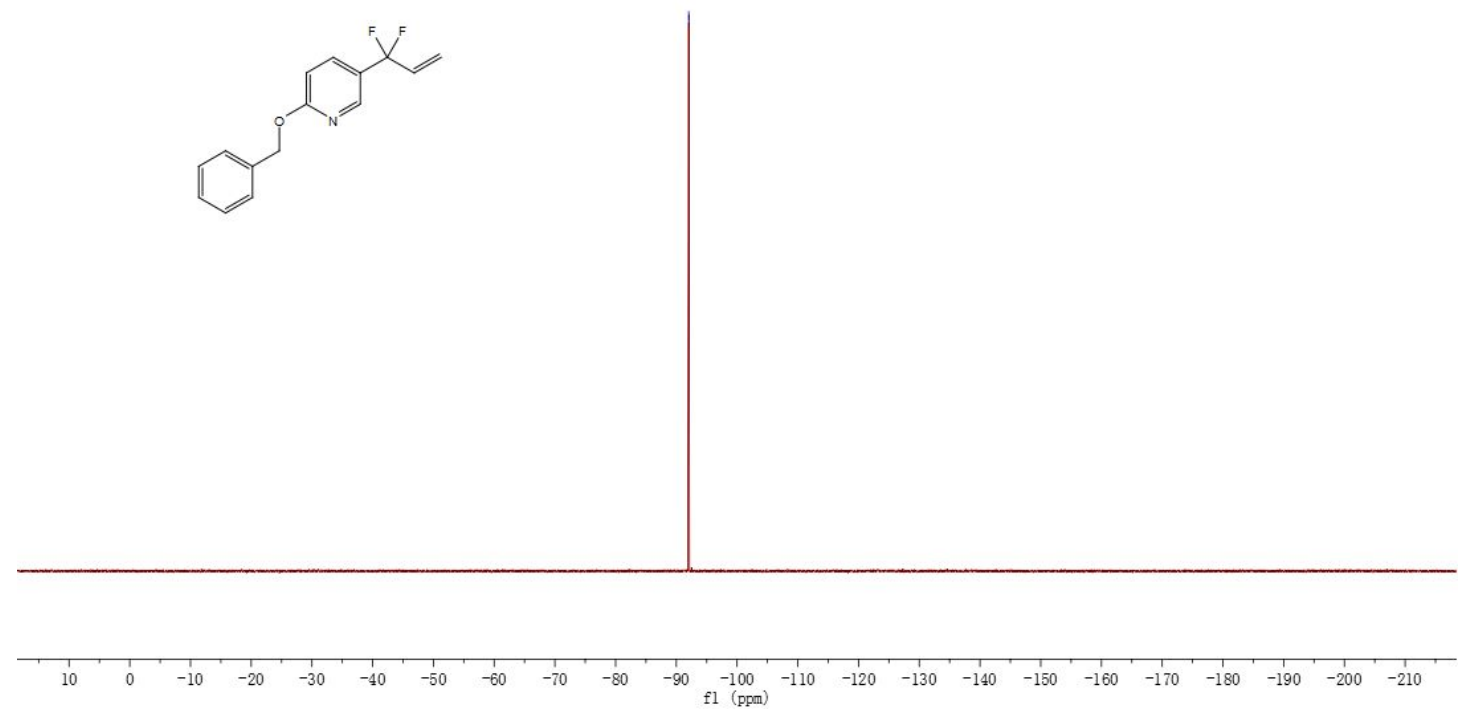


${ }^{13} \mathrm{C}\left\{{ }^{1} \mathrm{H}\right\}\left(101 \mathrm{MHz}, \mathrm{CDCl}_{3}\right)$ of $\mathbf{3 w}$

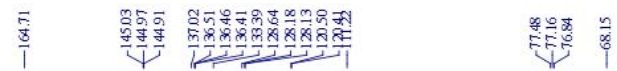

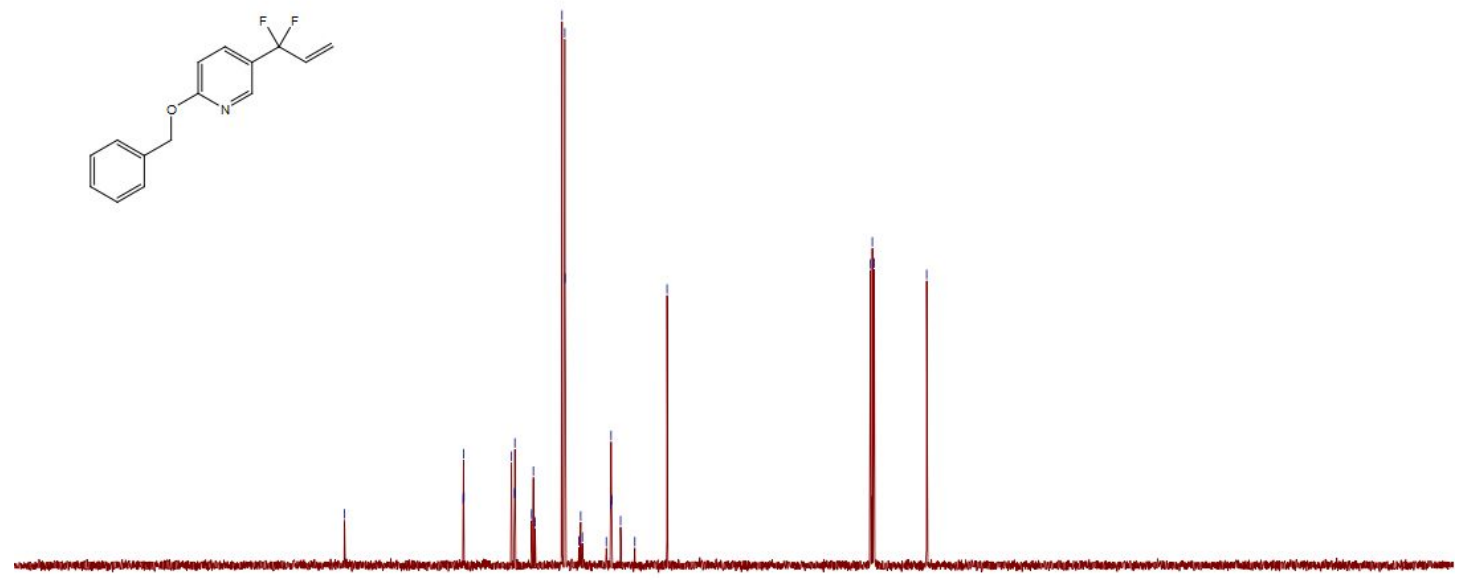

${ }^{1} \mathrm{H}\left(400 \mathrm{MHz}, \mathrm{CDCl}_{3}\right)$ of $\mathbf{3 x}$

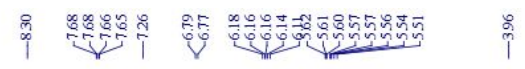

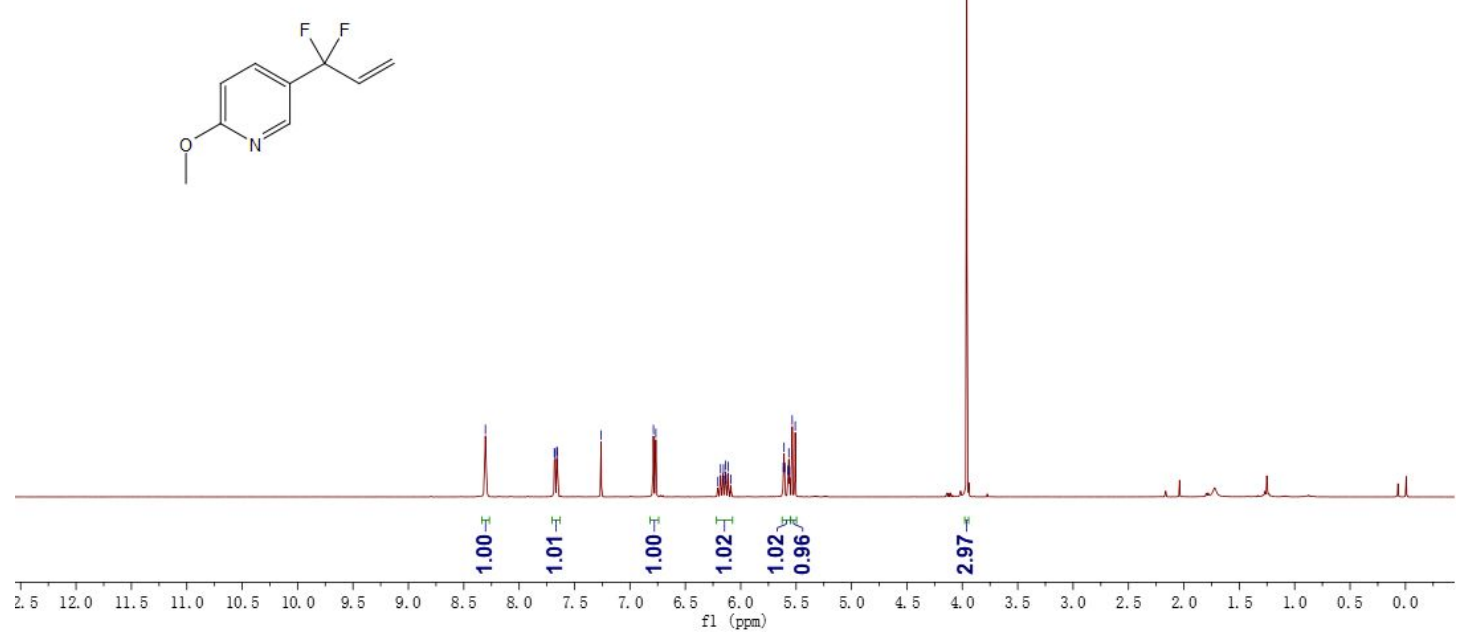


${ }^{19} \mathrm{~F}\left(376 \mathrm{MHz}, \mathrm{CDCl}_{3}\right)$ of $\mathbf{3 x}$
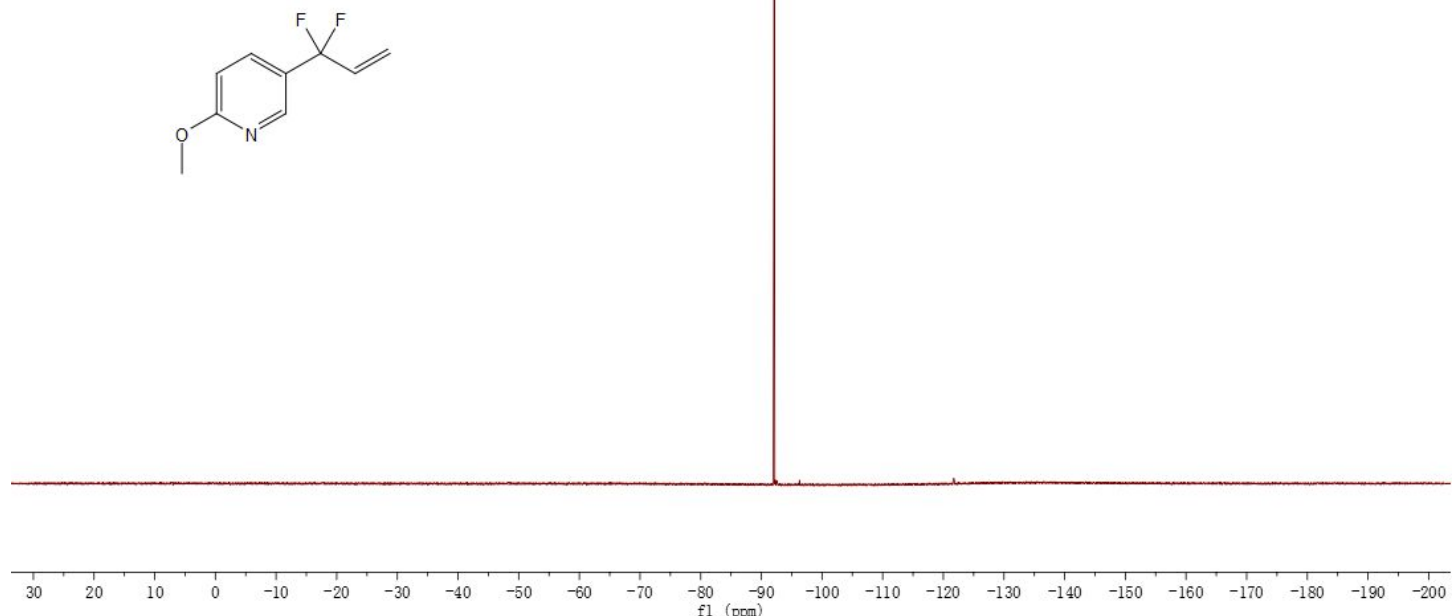

${ }^{13} \mathrm{C}\left\{{ }^{1} \mathrm{H}\right\}\left(101 \mathrm{MHz}, \mathrm{CDCl}_{3}\right)$ of $\mathbf{3} \mathbf{x}$

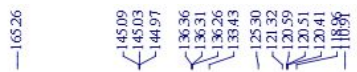<smiles>C=CC(C)(C)c1ccc(OC)nc1</smiles>

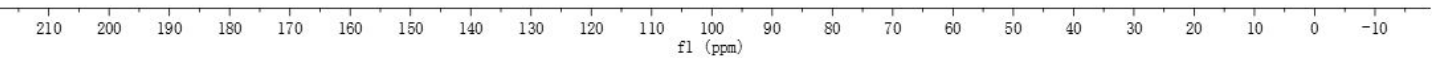


${ }^{1} \mathrm{H}\left(400 \mathrm{MHz}, \mathrm{CDCl}_{3}\right)$ of $\mathbf{3 y}$

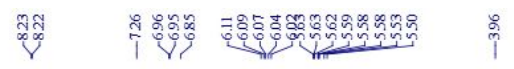

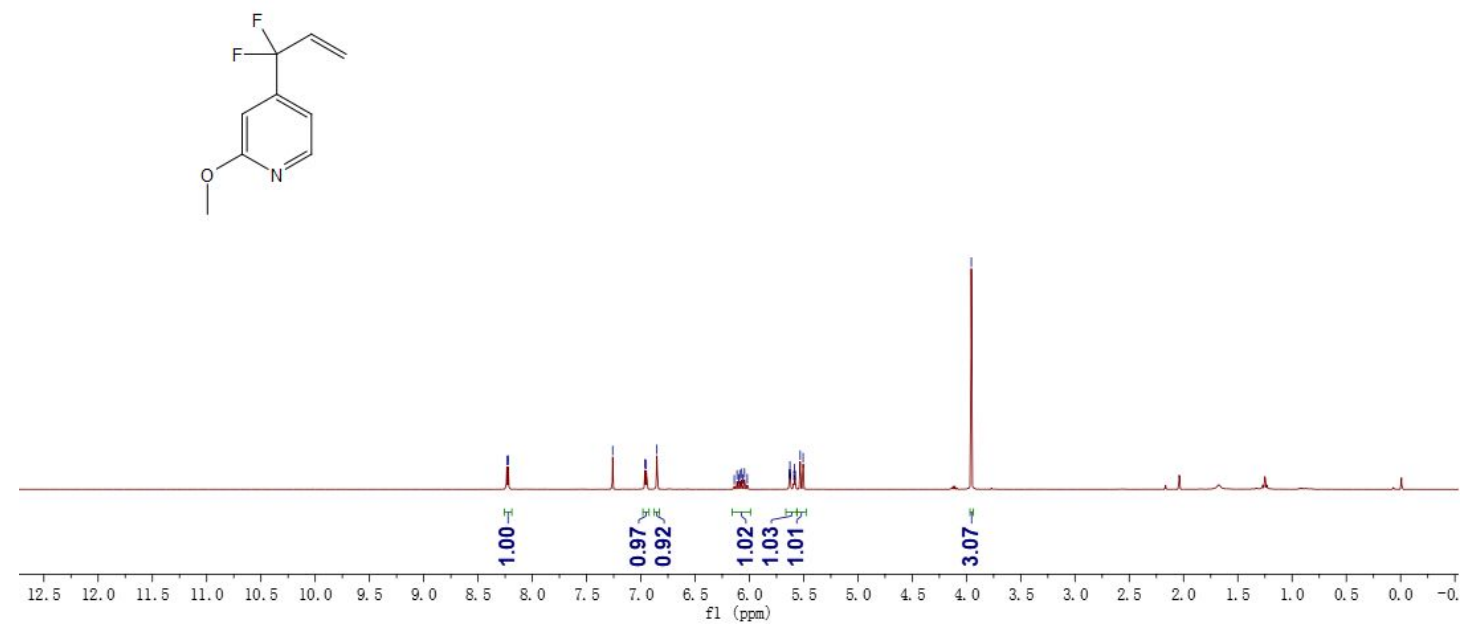<smiles>C=CC1CCC1</smiles>

${ }^{19} \mathrm{~F}\left(376 \mathrm{MHz}, \mathrm{CDCl}_{3}\right)$ of $\mathbf{3 y}$

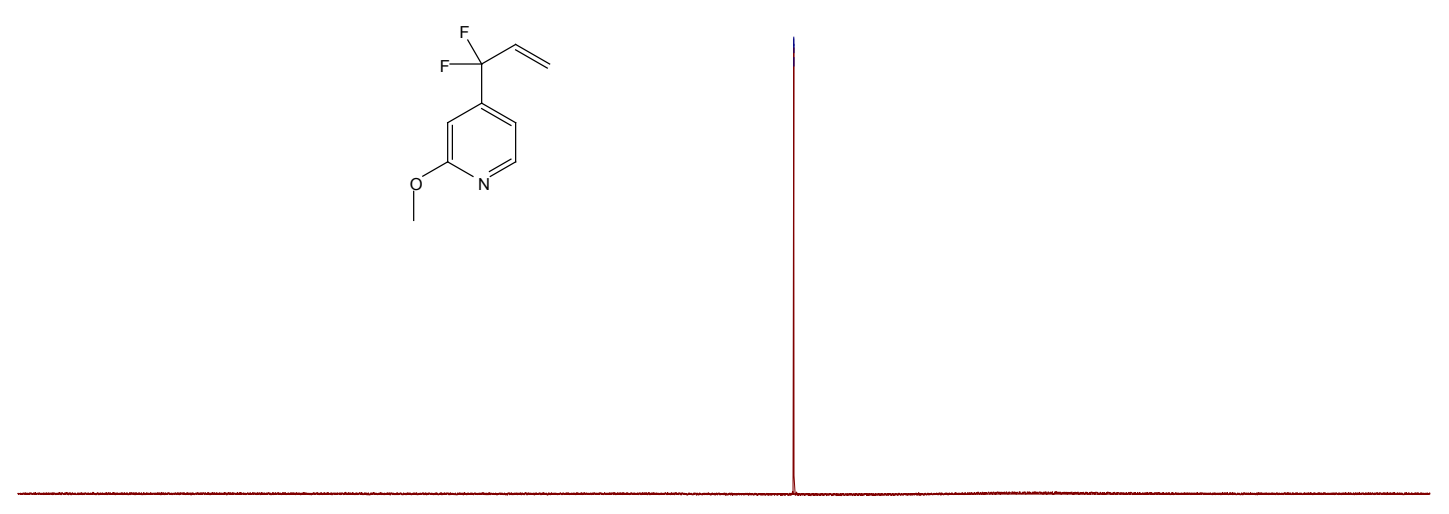

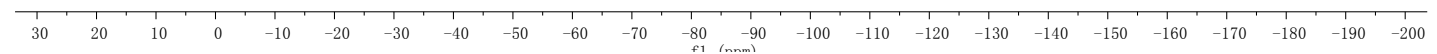


${ }^{13} \mathrm{C}\left\{{ }^{1} \mathrm{H}\right\}\left(101 \mathrm{MHz}, \mathrm{CDCl}_{3}\right)$ of $\mathbf{3 y}$

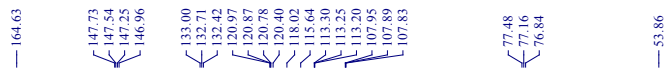
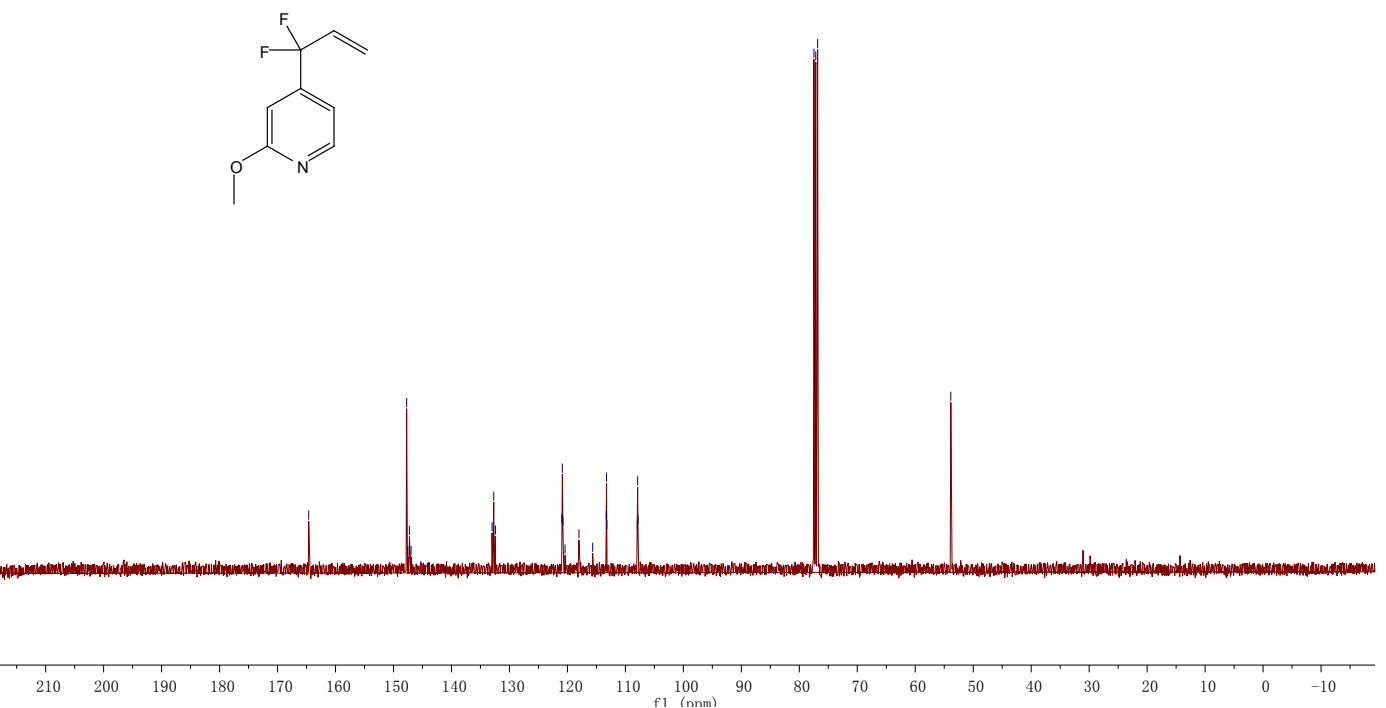

${ }^{1} \mathrm{H}\left(400 \mathrm{MHz}, \mathrm{CDCl}_{3}\right)$ of $\mathbf{6 a}$

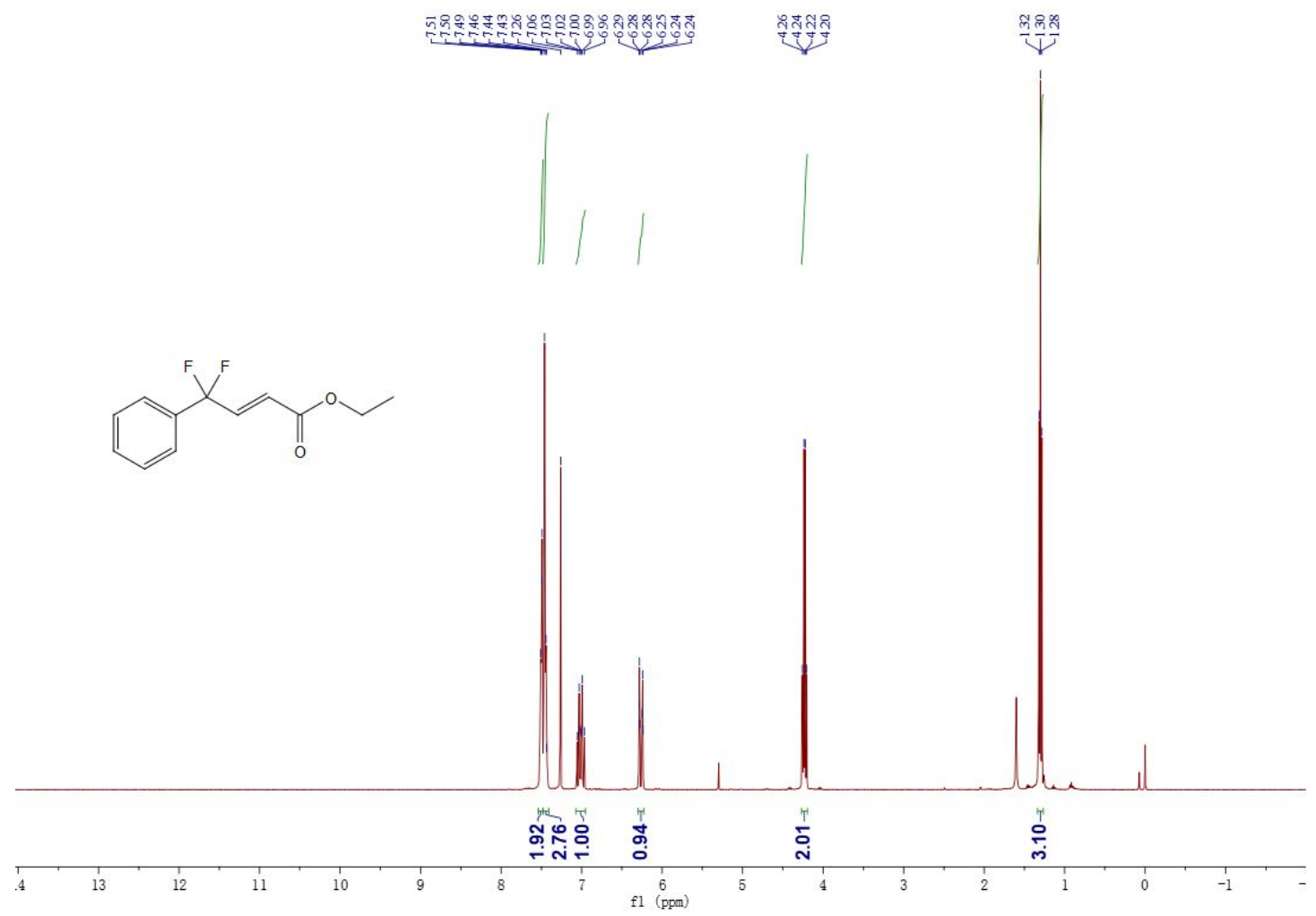


${ }^{19} \mathrm{~F}\left(376 \mathrm{MHz}, \mathrm{CDCl}_{3}\right)$ of $\mathbf{6 a}$

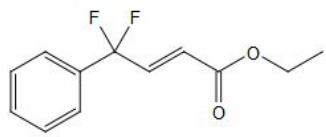

\begin{tabular}{llllllllllllllllllllllllllllllllllll}
\hline & 1 & 1 & 1 & 10 & 0 & -10 & -20 & -30 & -40 & -50 & -60 & -70 & -80 & -90 & -100 & -110 & -120 & -130 & -140 & -150 & -160 & -170 & -180 & -190 & -200
\end{tabular}

${ }^{13} \mathrm{C}\left\{{ }^{1} \mathrm{H}\right\}\left(101 \mathrm{MHz}, \mathrm{CDCl}_{3}\right)$ of $\mathbf{6 a}$
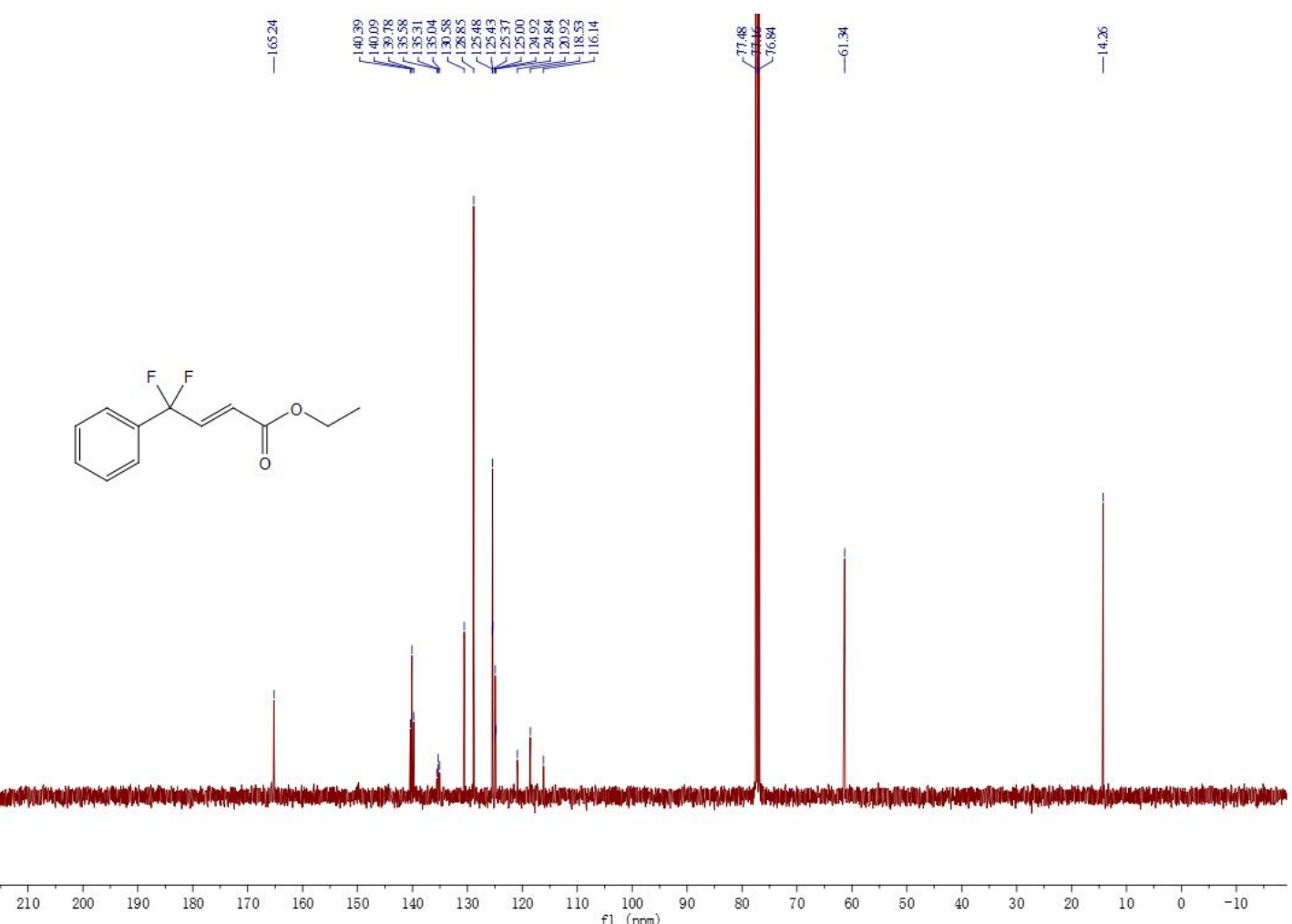
${ }^{1} \mathrm{H}\left(400 \mathrm{MHz}, \mathrm{CDCl}_{3}\right)$ of $\mathbf{6 b}(E / Z=9 / 1)$

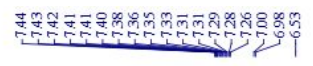

$\stackrel{\wp}{i}$
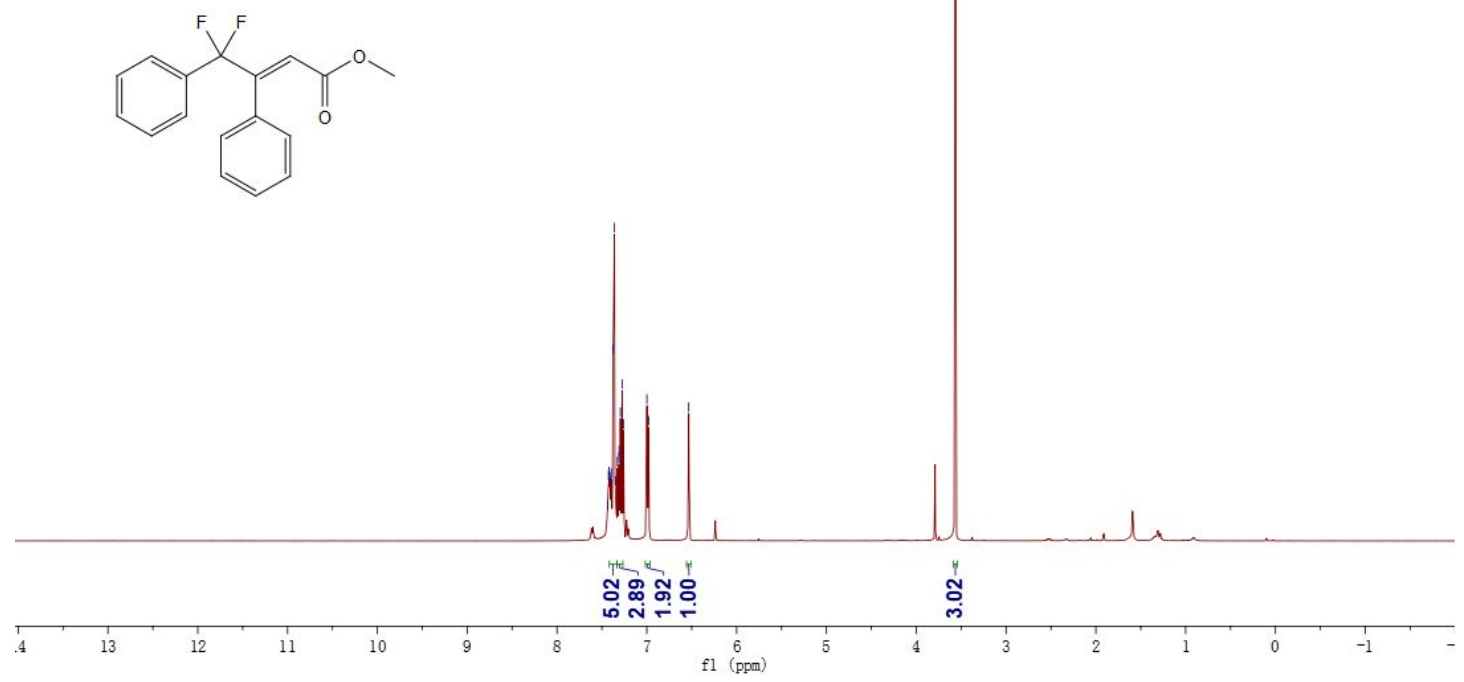

${ }^{19} \mathrm{~F}\left(376 \mathrm{MHz}, \mathrm{CDCl}_{3}\right)$ of $\mathbf{6 b}(E / Z=9 / 1)$

के
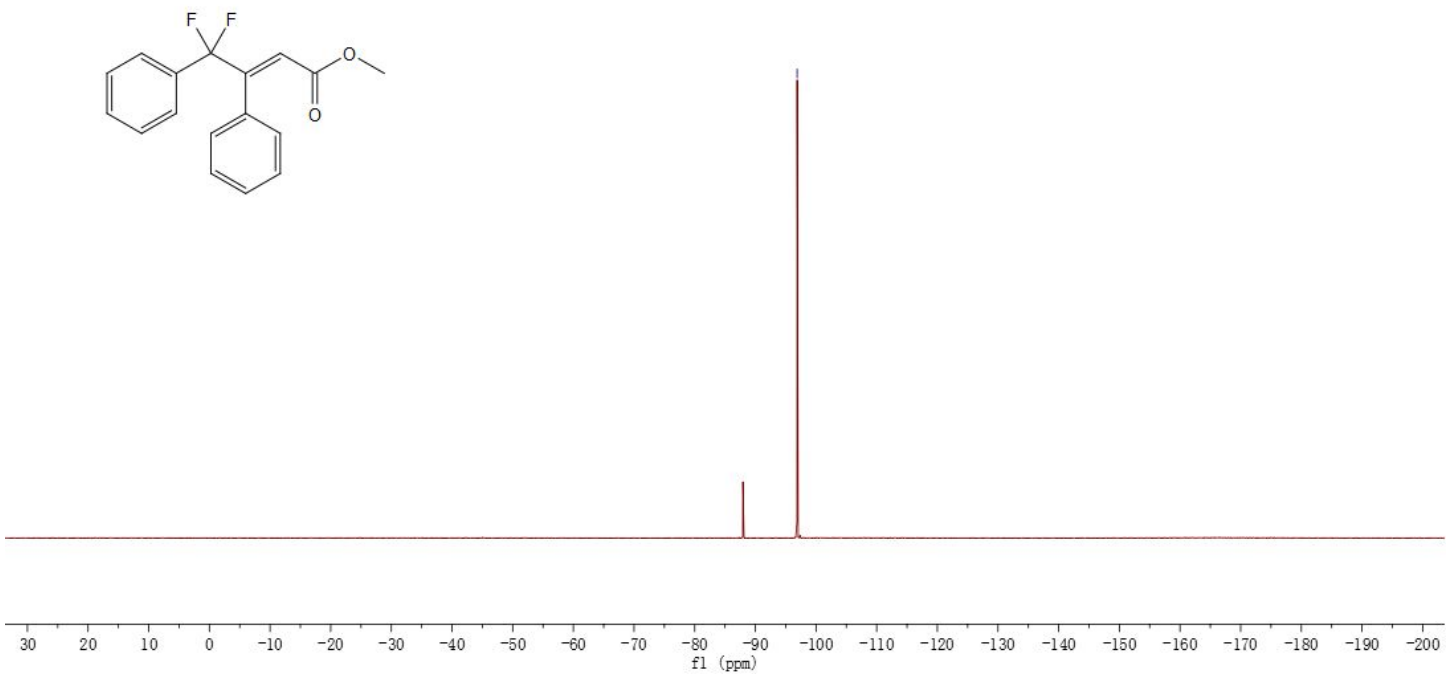

S69 
${ }^{13} \mathrm{C}\left\{{ }^{1} \mathrm{H}\right\}\left(101 \mathrm{MHz}, \mathrm{CDCl}_{3}\right)$ of $\mathbf{6 b}(E / Z=9 / 1)$

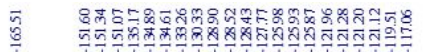
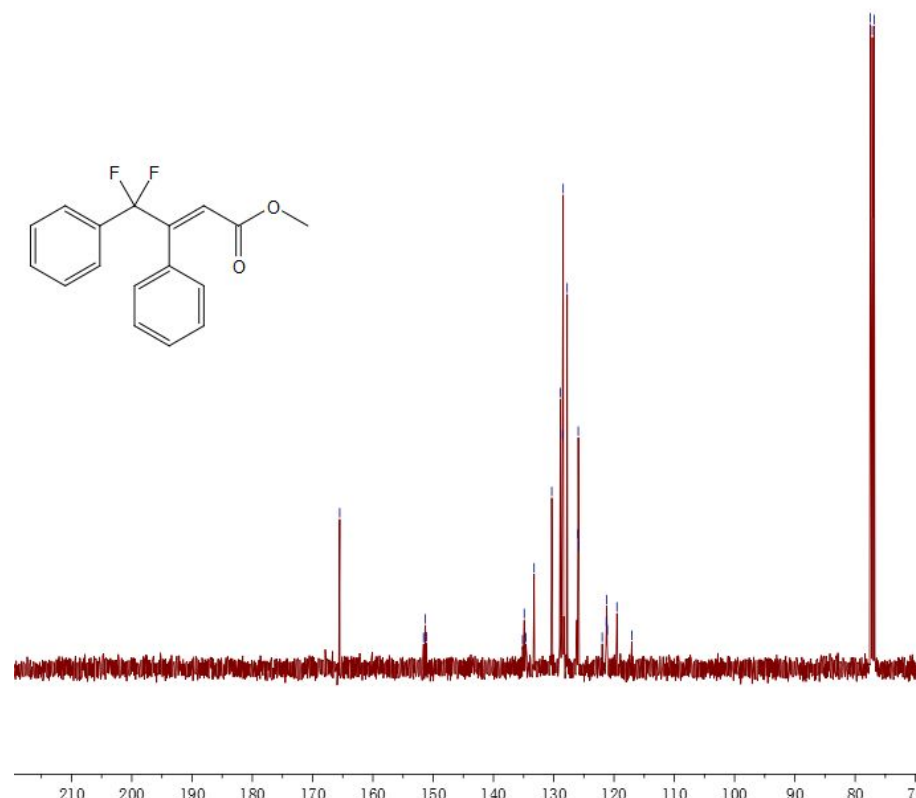

${ }^{1} \mathrm{H}\left(400 \mathrm{MHz}, \mathrm{CDCl}_{3}\right)$ of $\mathbf{6 c}$

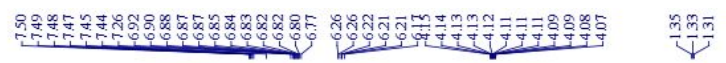
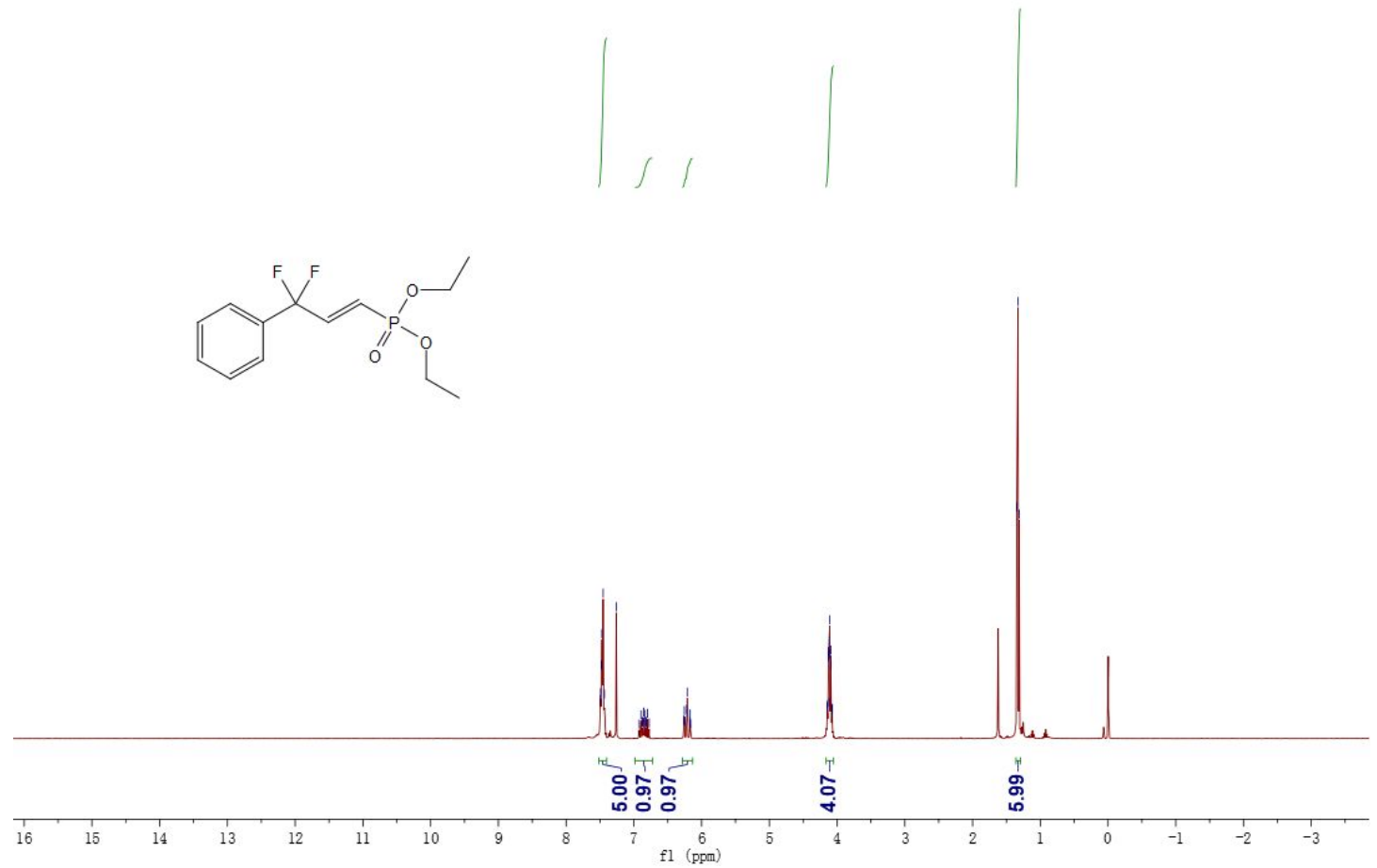
${ }^{19} \mathrm{~F}\left(376 \mathrm{MHz}, \mathrm{CDCl}_{3}\right)$ of $\mathbf{6 c}$

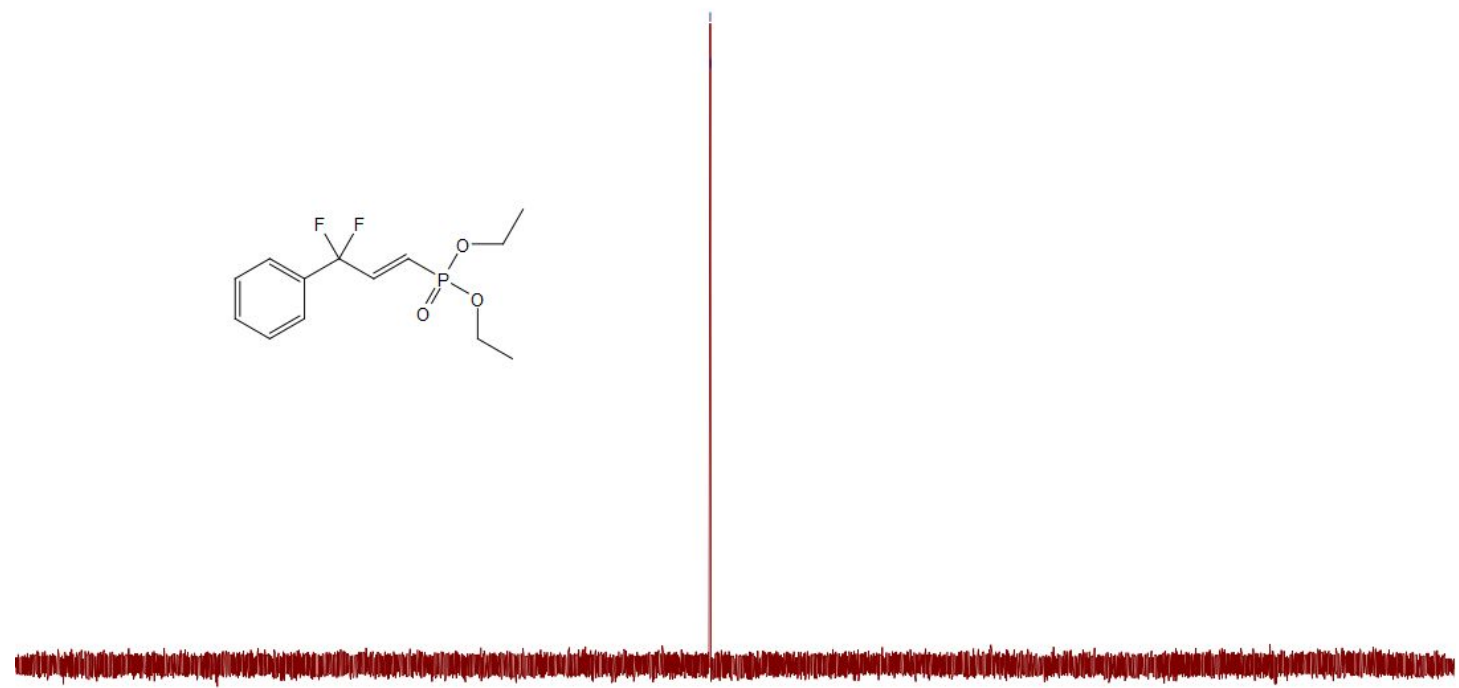

\begin{tabular}{lllllllllllllllllllllllllll}
\hline 10 & 0 & -10 & -20 & -30 & -40 & -50 & -60 & -70 & -80 & -90 & -100 & -110 & -120 & -130 & -140 & -150 & -160 & -170 & -180 & -190 & -200 & -210 & 1
\end{tabular}

${ }^{13} \mathrm{C}\left\{{ }^{1} \mathrm{H}\right\}\left(176 \mathrm{MHz}, \mathrm{CDCl}_{3}\right)$ of $\mathbf{6 c}$

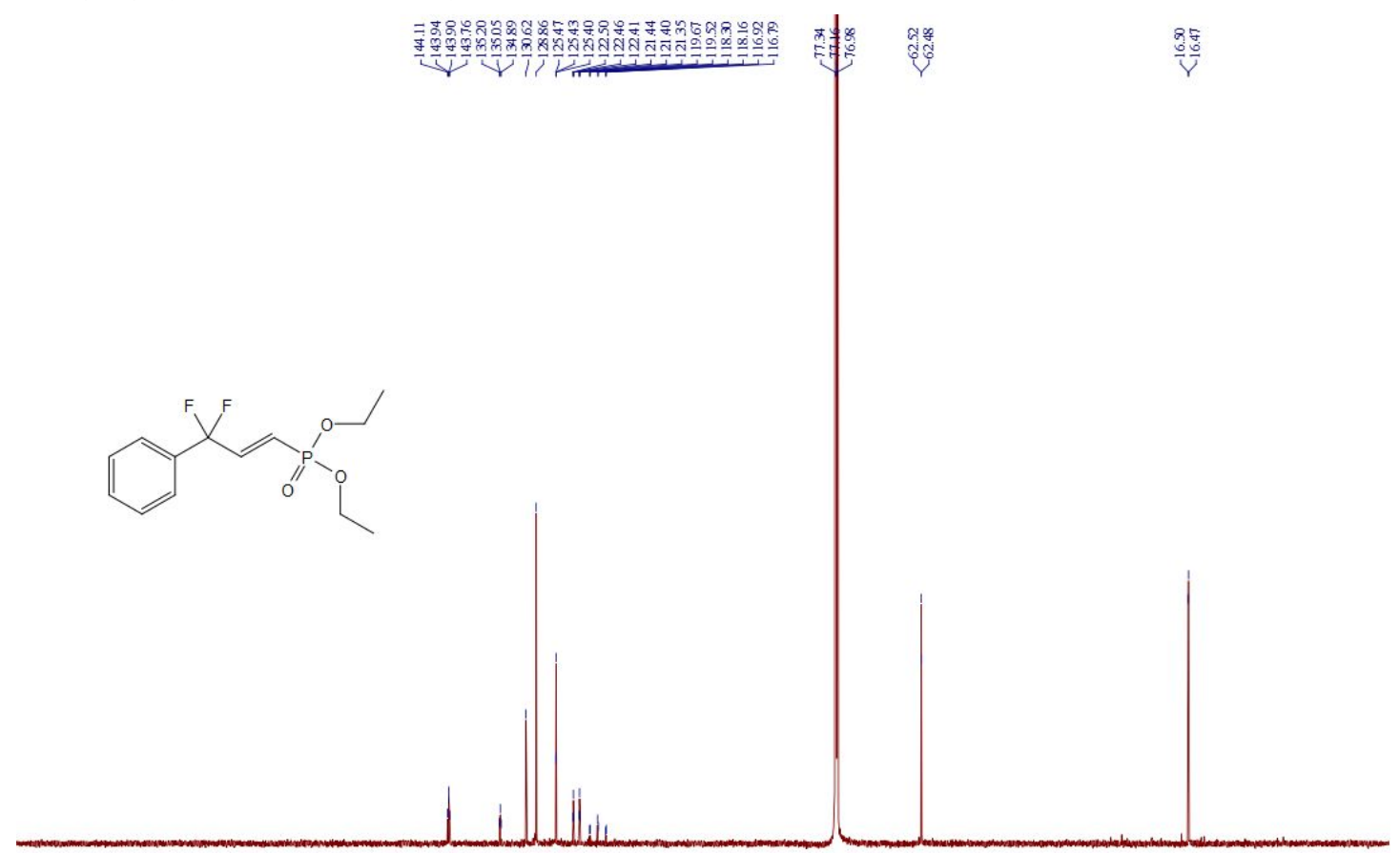

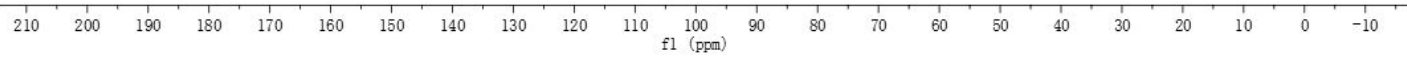


${ }^{31} \mathrm{P}\left\{{ }^{1} \mathrm{H}\right\}\left(162 \mathrm{MHz}, \mathrm{CDCl}_{3}\right)$ of $\mathbf{6 c}$
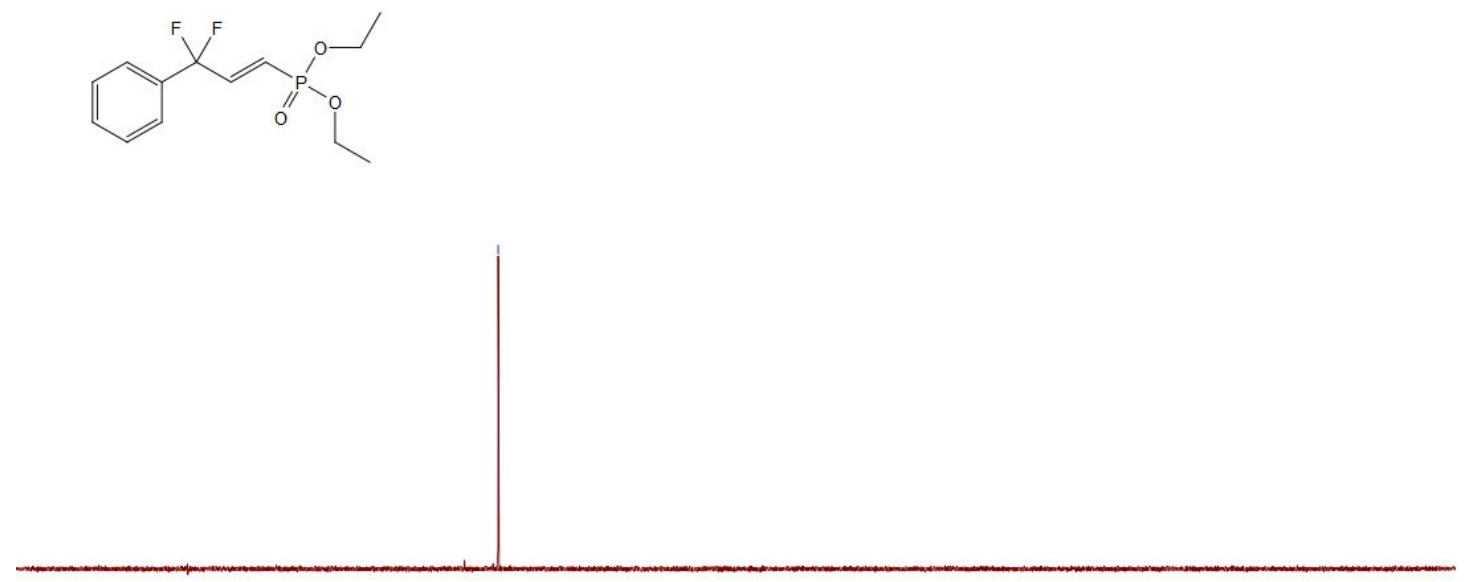

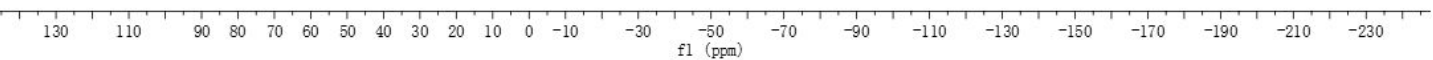

${ }^{1} \mathrm{H}\left(400 \mathrm{MHz}, \mathrm{CDCl}_{3}\right)$ of $\mathbf{6 d}$

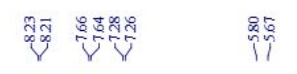

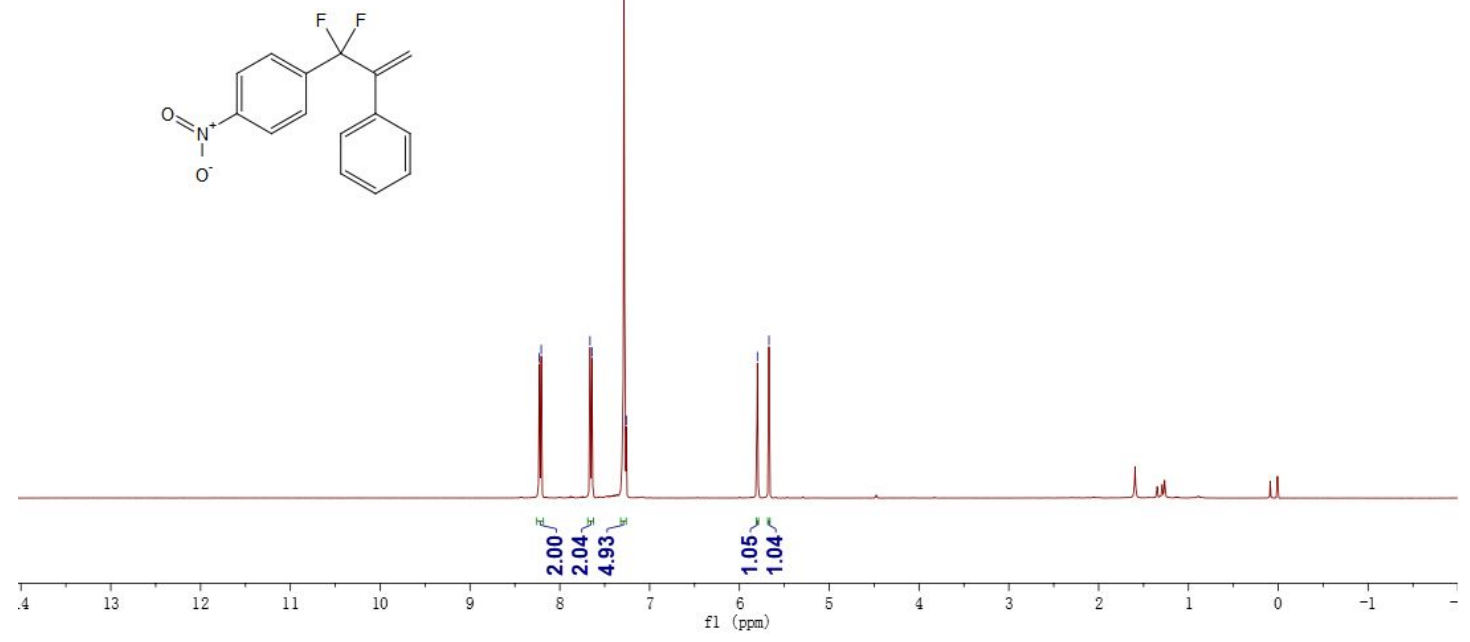


${ }^{19} \mathrm{~F}\left(376 \mathrm{MHz}, \mathrm{CDCl}_{3}\right)$ of $\mathbf{6 d}$
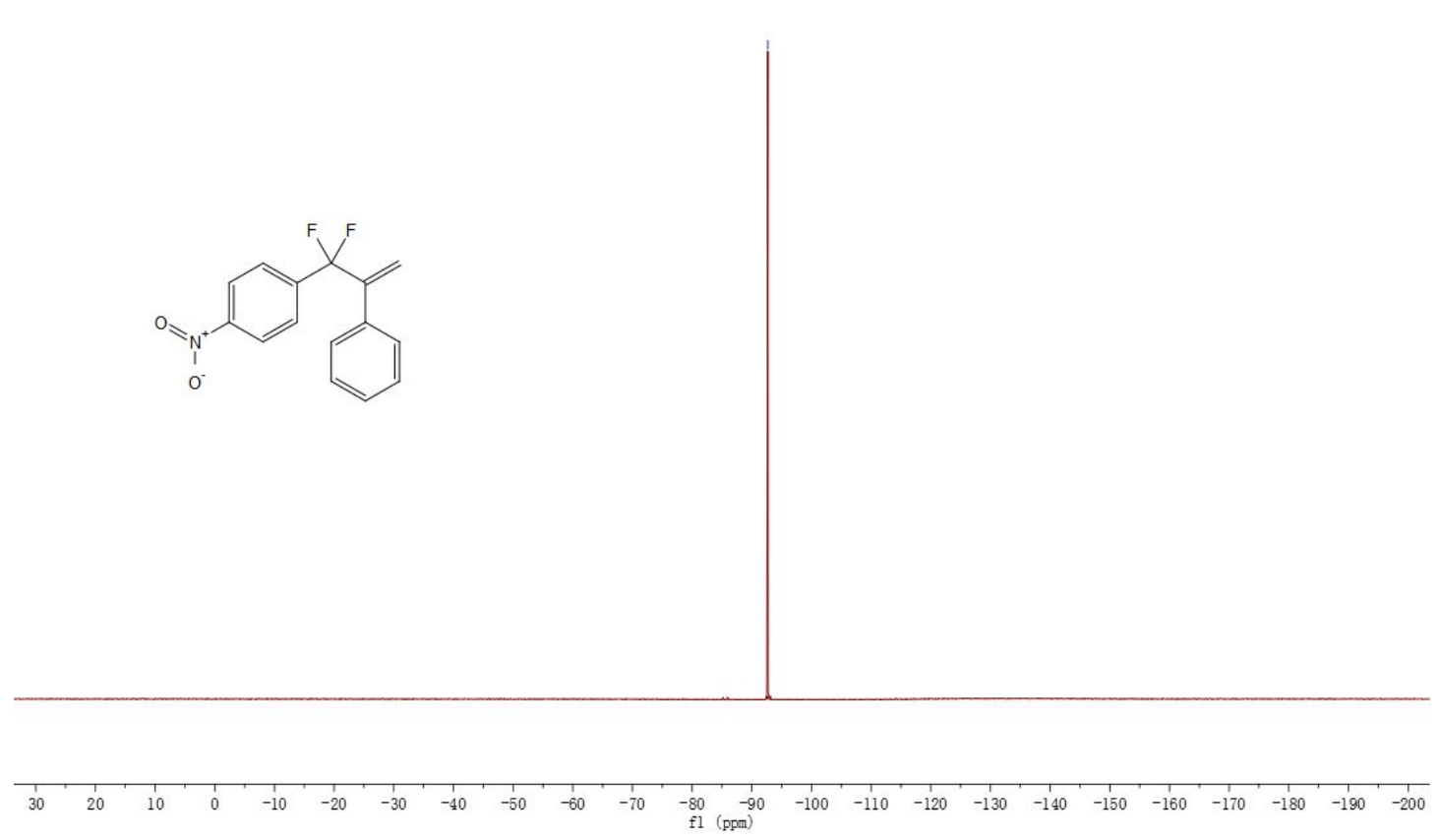

${ }^{13} \mathrm{C}\left\{{ }^{1} \mathrm{H}\right\}\left(176 \mathrm{MHz}, \mathrm{CDCl}_{3}\right)$ of $\mathbf{6 d}$

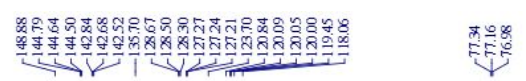

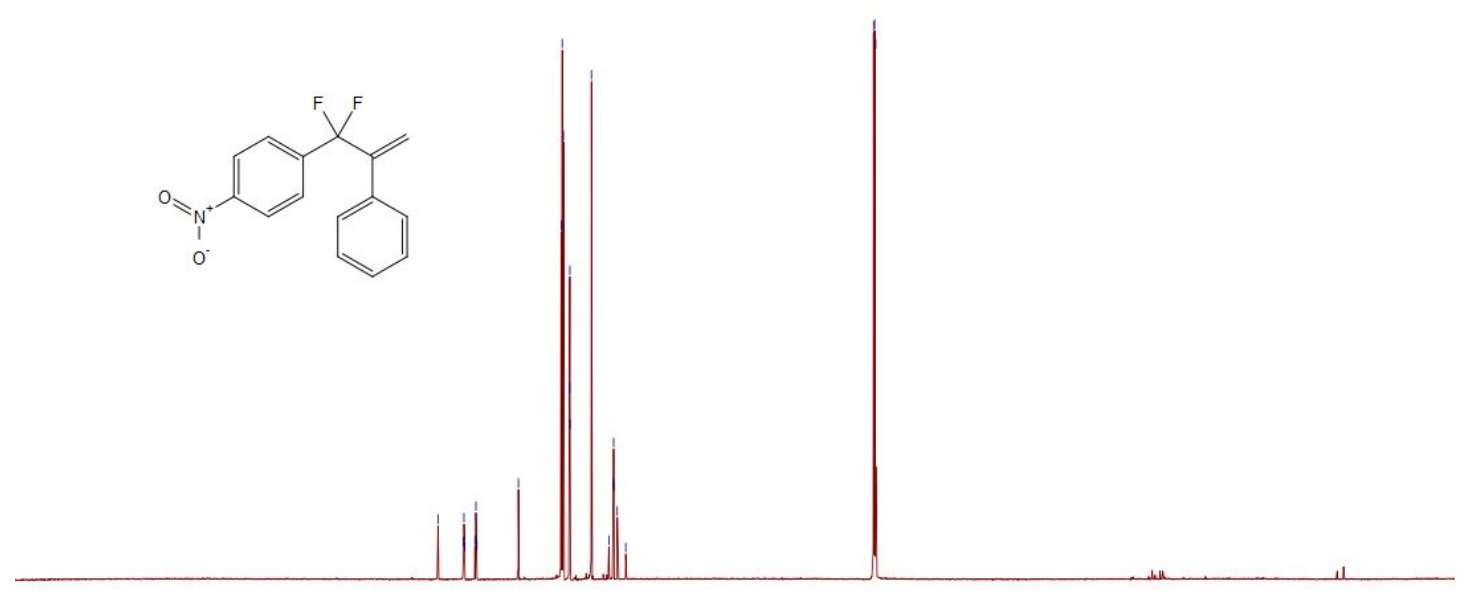

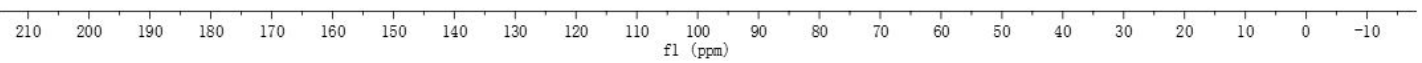


${ }^{1} \mathrm{H}\left(400 \mathrm{MHz}, \mathrm{CDCl}_{3}\right)$ of $\mathbf{6 e}$

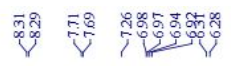

ํํำ졍

ติำ
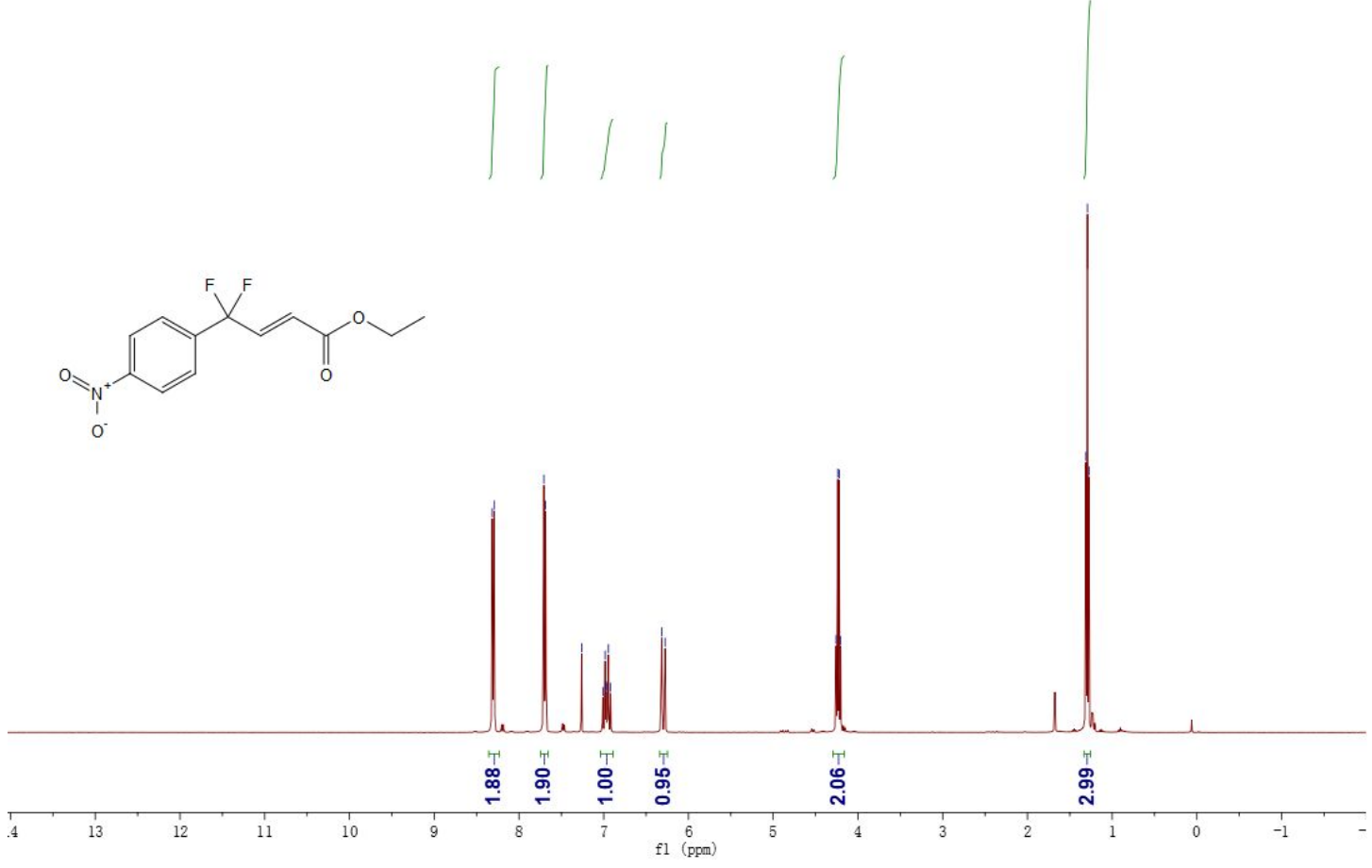

${ }^{19} \mathrm{~F}\left(376 \mathrm{MHz}, \mathrm{CDCl}_{3}\right)$ of $\mathbf{6 e}$
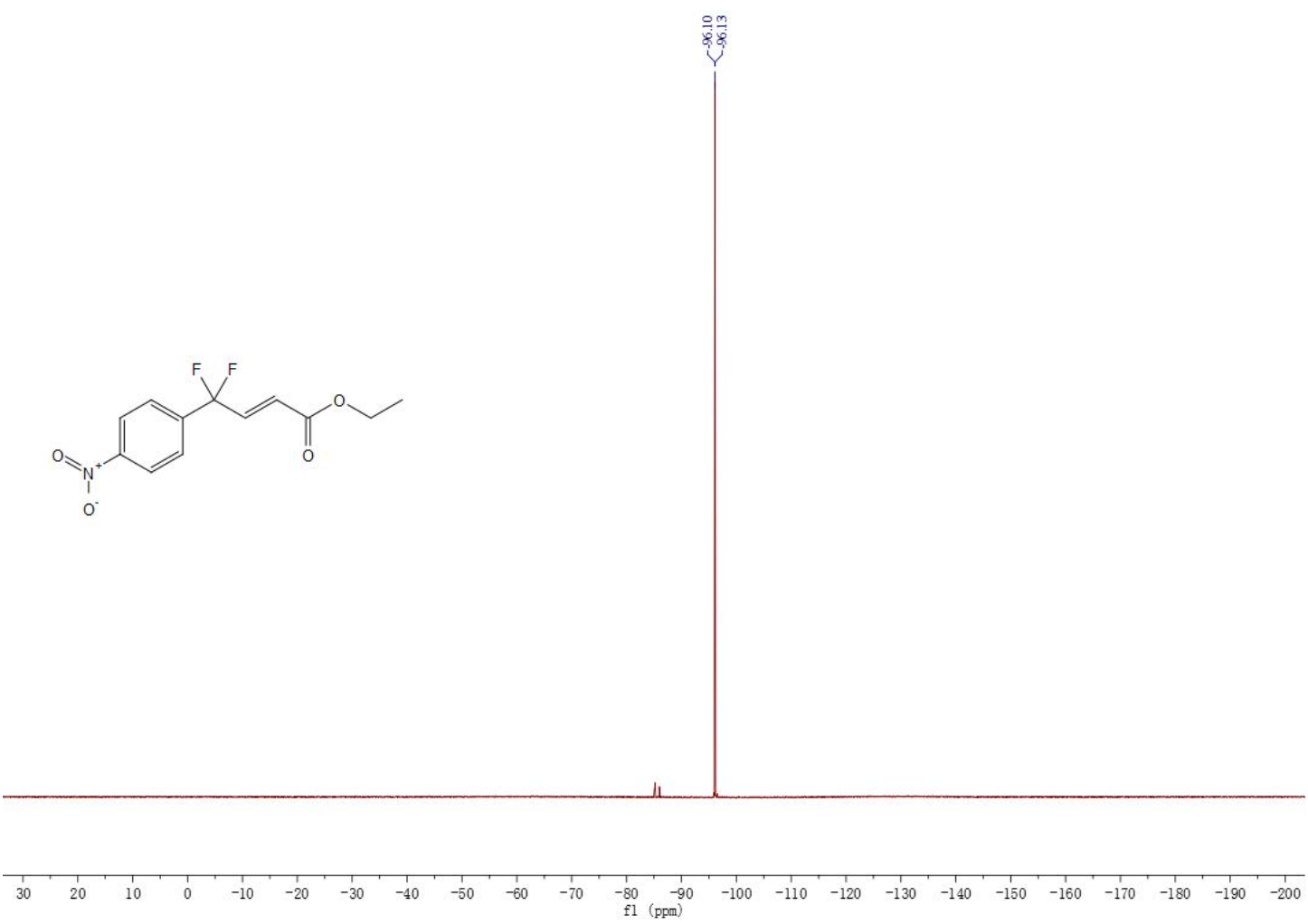

S74 
${ }^{13} \mathrm{C}\left\{{ }^{1} \mathrm{H}\right\}\left(101 \mathrm{MHz}, \mathrm{CDCl}_{3}\right)$ of $\mathbf{6 e}$

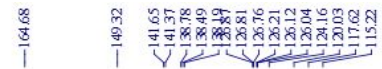

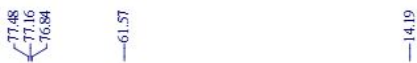

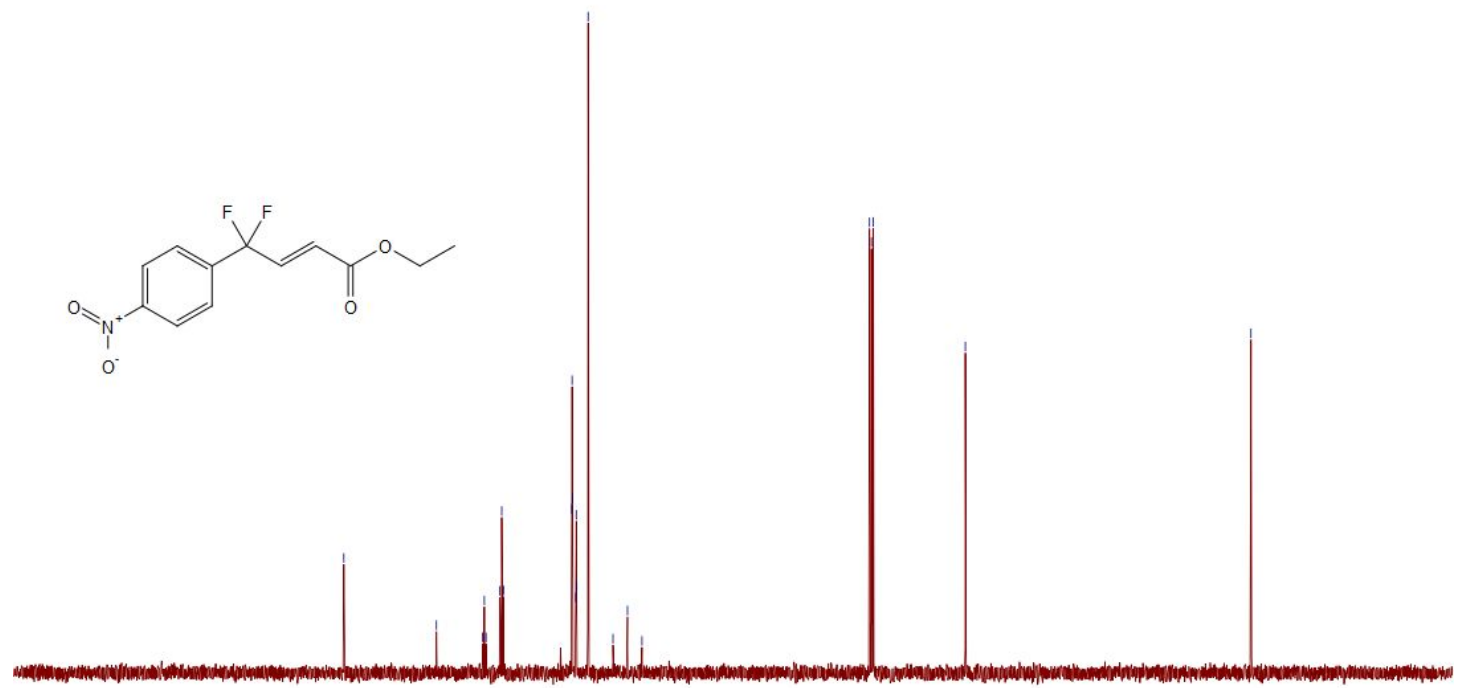

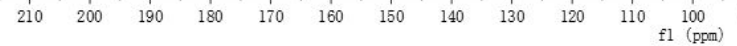

${ }^{1} \mathrm{H}\left(400 \mathrm{MHz}, \mathrm{CDCl}_{3}\right)$ of $\mathbf{6 f}$

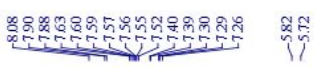
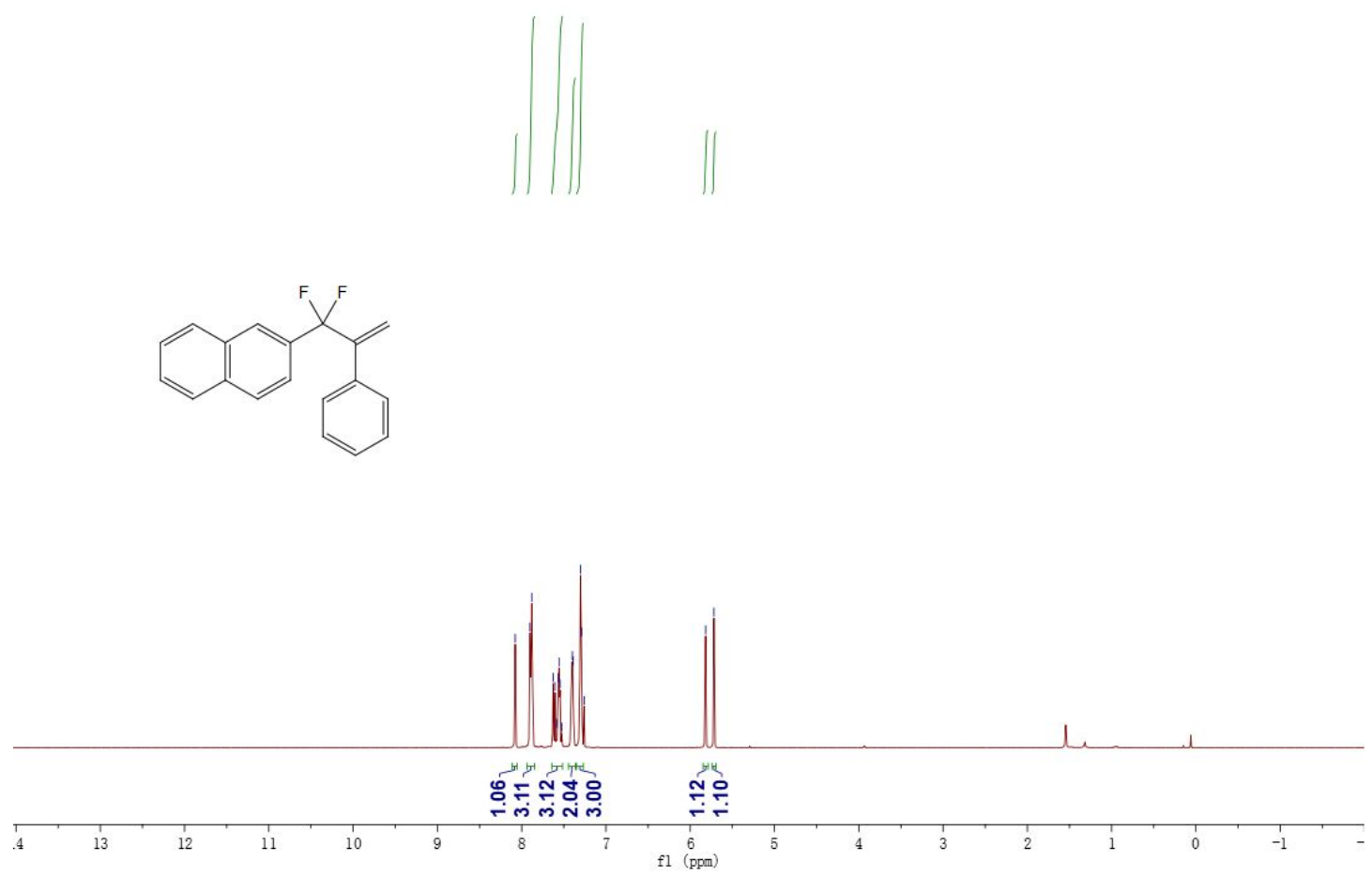
${ }^{19} \mathrm{~F}\left(376 \mathrm{MHz}, \mathrm{CDCl}_{3}\right)$ of $\mathbf{6 f}$

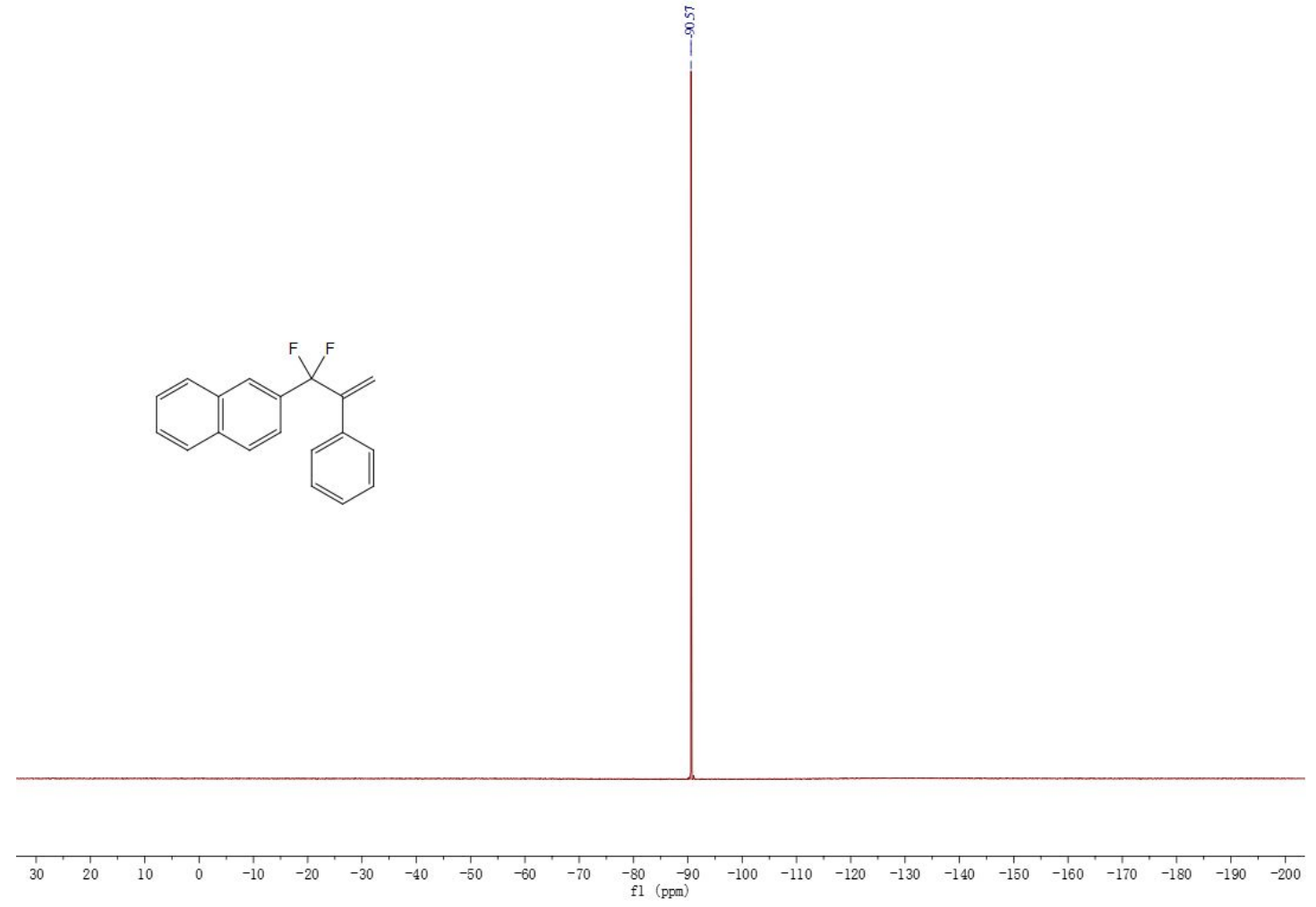

${ }^{13} \mathrm{C}\left\{{ }^{1} \mathrm{H}\right\}\left(176 \mathrm{MHz}, \mathrm{CDCl}_{3}\right)$ of $\mathbf{6} \mathbf{f}$

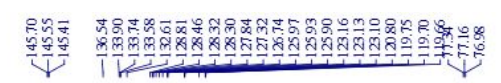

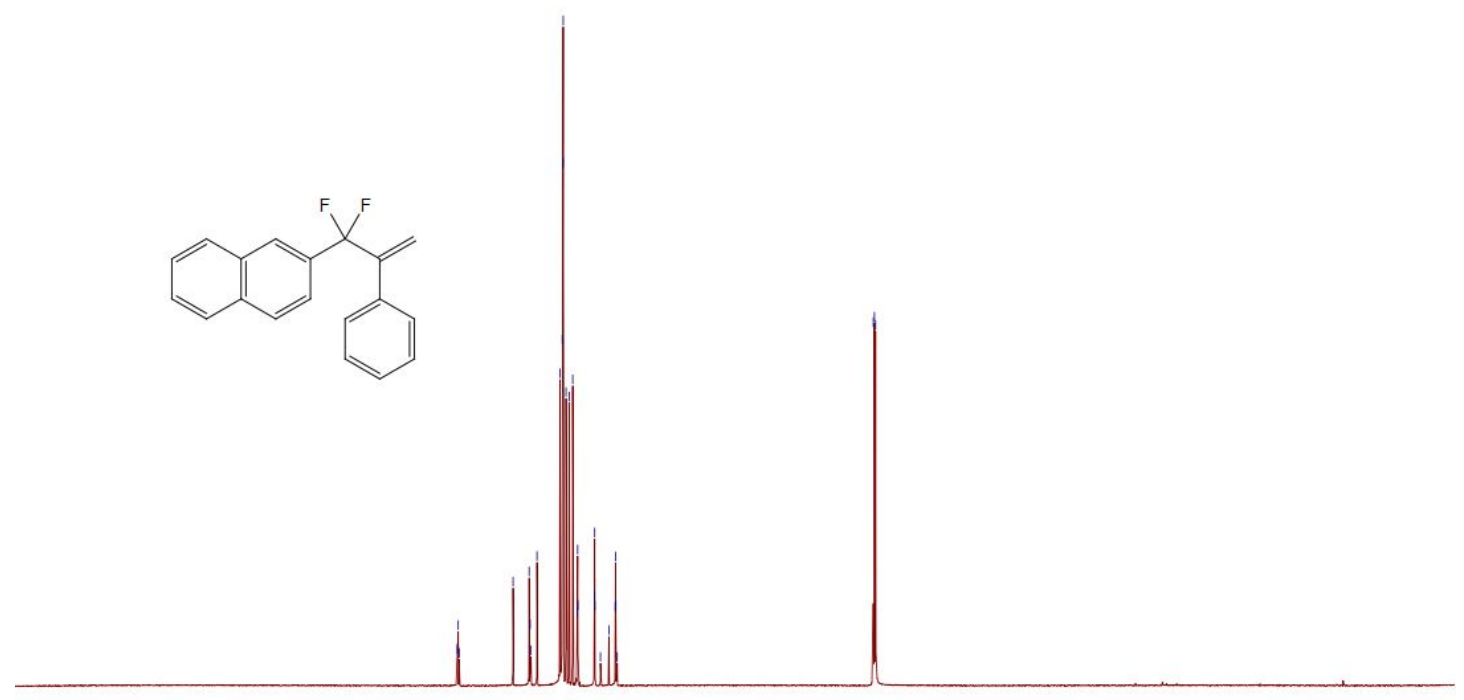

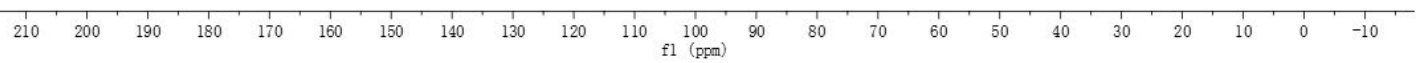


${ }^{1} \mathrm{H}\left(400 \mathrm{MHz}, \mathrm{CDCl}_{3}\right)$ of $\mathbf{6 g}$

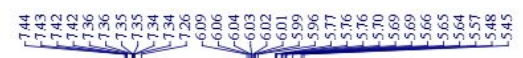

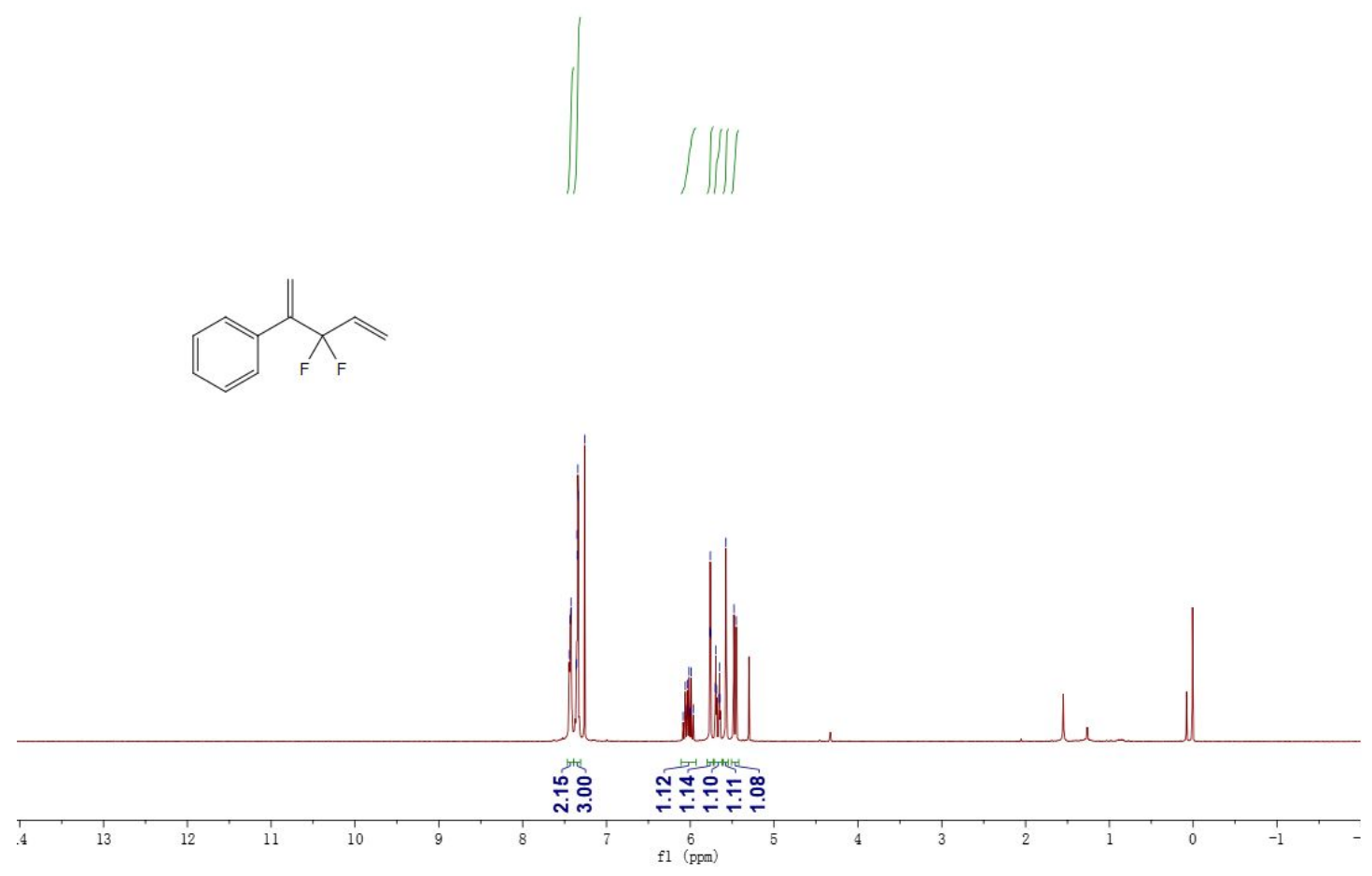

${ }^{19} \mathrm{~F}\left(376 \mathrm{MHz}, \mathrm{CDCl}_{3}\right)$ of $\mathbf{6 g}$

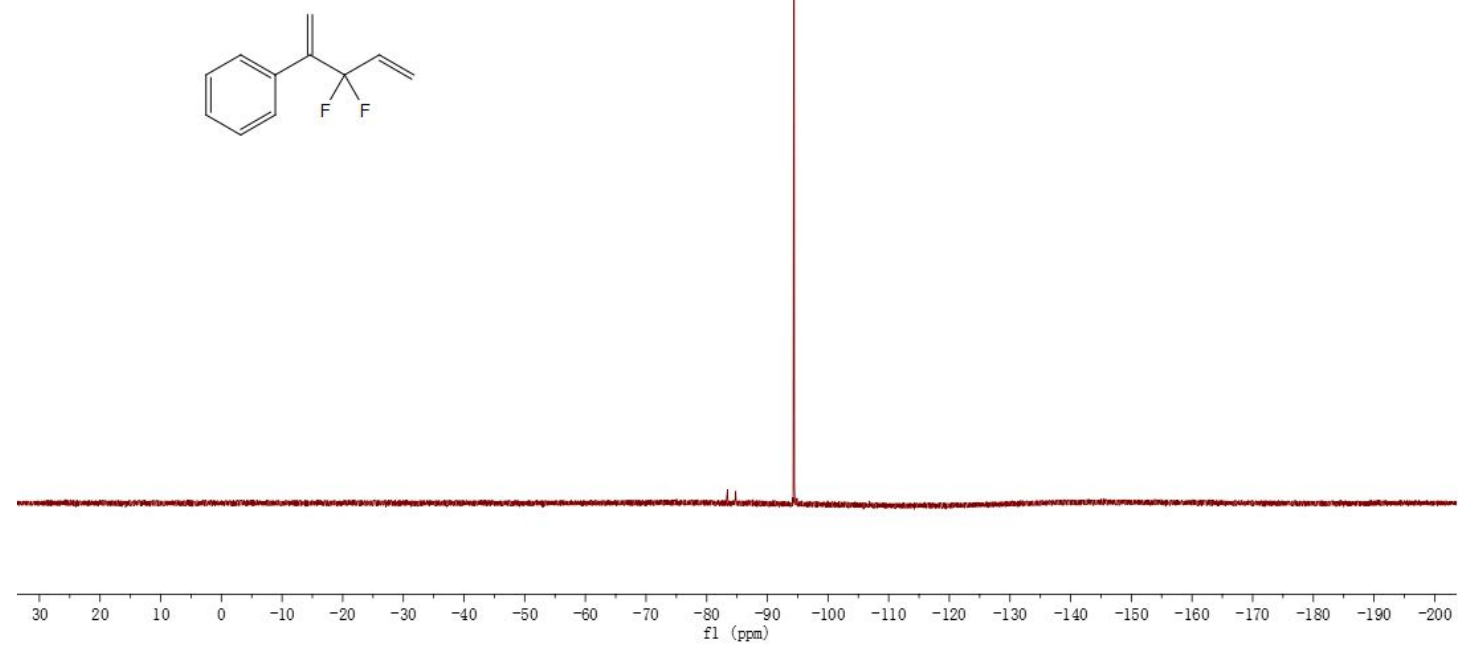


${ }^{13} \mathrm{C}\left\{{ }^{1} \mathrm{H}\right\}\left(101 \mathrm{MHz}, \mathrm{CDCl}_{3}\right)$ of $\mathbf{6 g}$
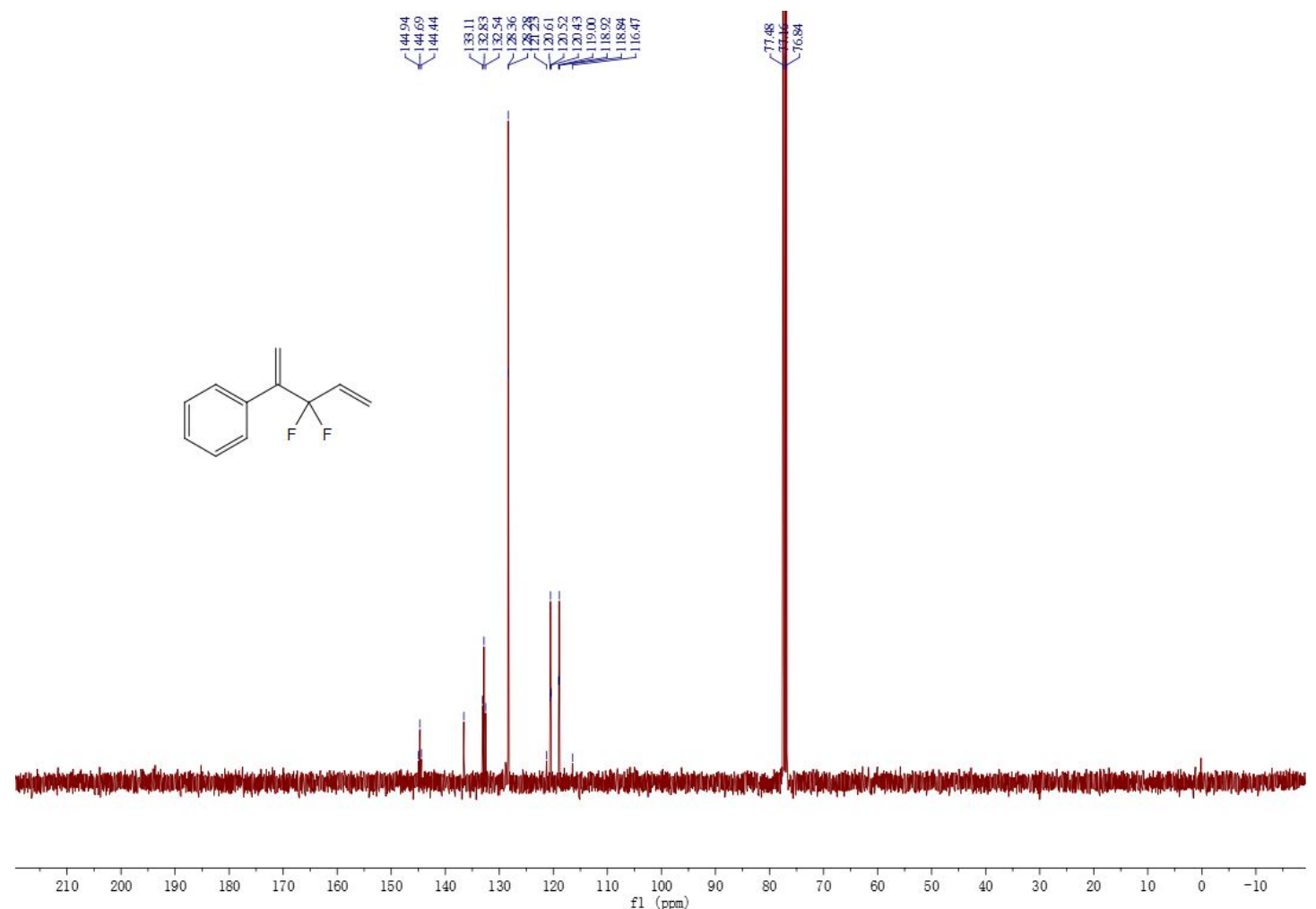

${ }^{1} \mathrm{H}\left(400 \mathrm{MHz}, \mathrm{CDCl}_{3}\right)$ of $\mathbf{6 h}$

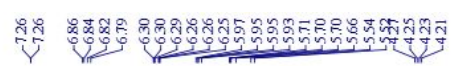
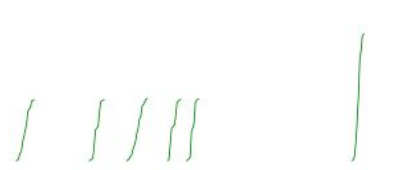

$\underbrace{}_{F F}$

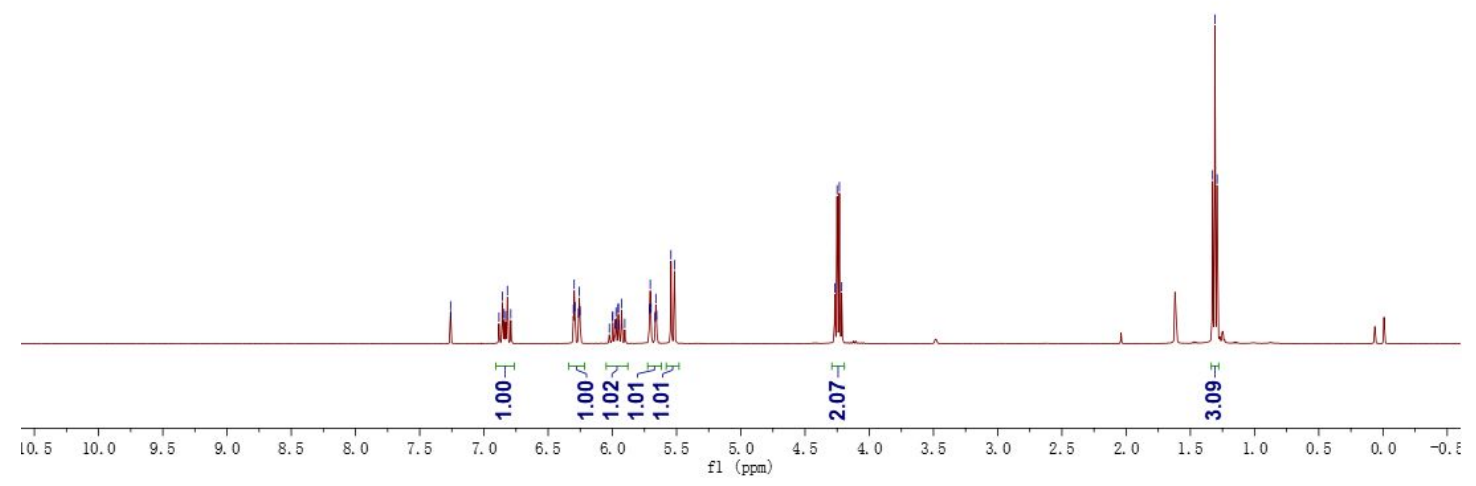


${ }^{19} \mathrm{~F}\left(376 \mathrm{MHz}, \mathrm{CDCl}_{3}\right)$ of $\mathbf{6 h}$
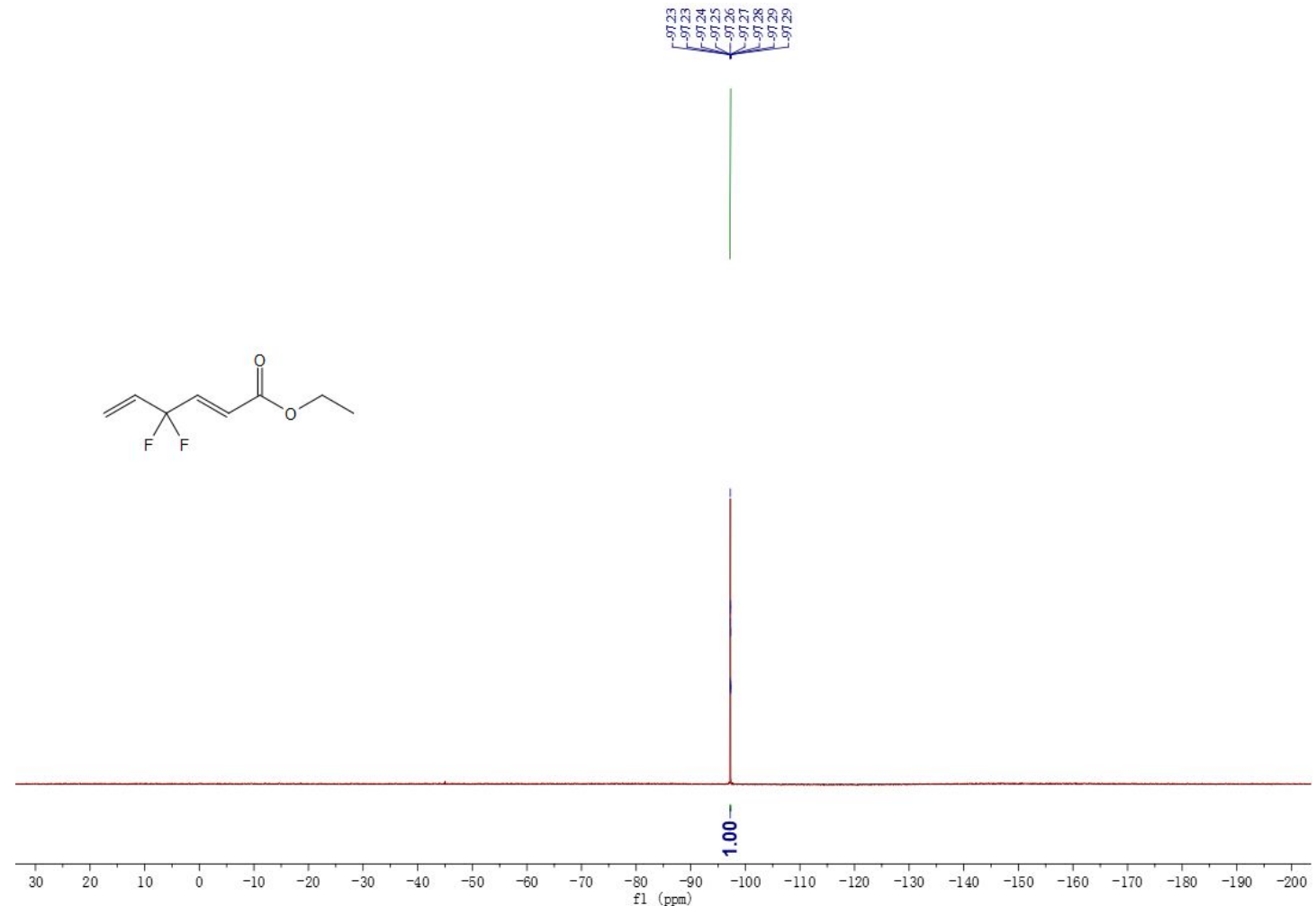

${ }^{13} \mathrm{C}\left\{{ }^{1} \mathrm{H}\right\}\left(101 \mathrm{MHz}, \mathrm{CDCl}_{3}\right)$ of $\mathbf{6 h}$
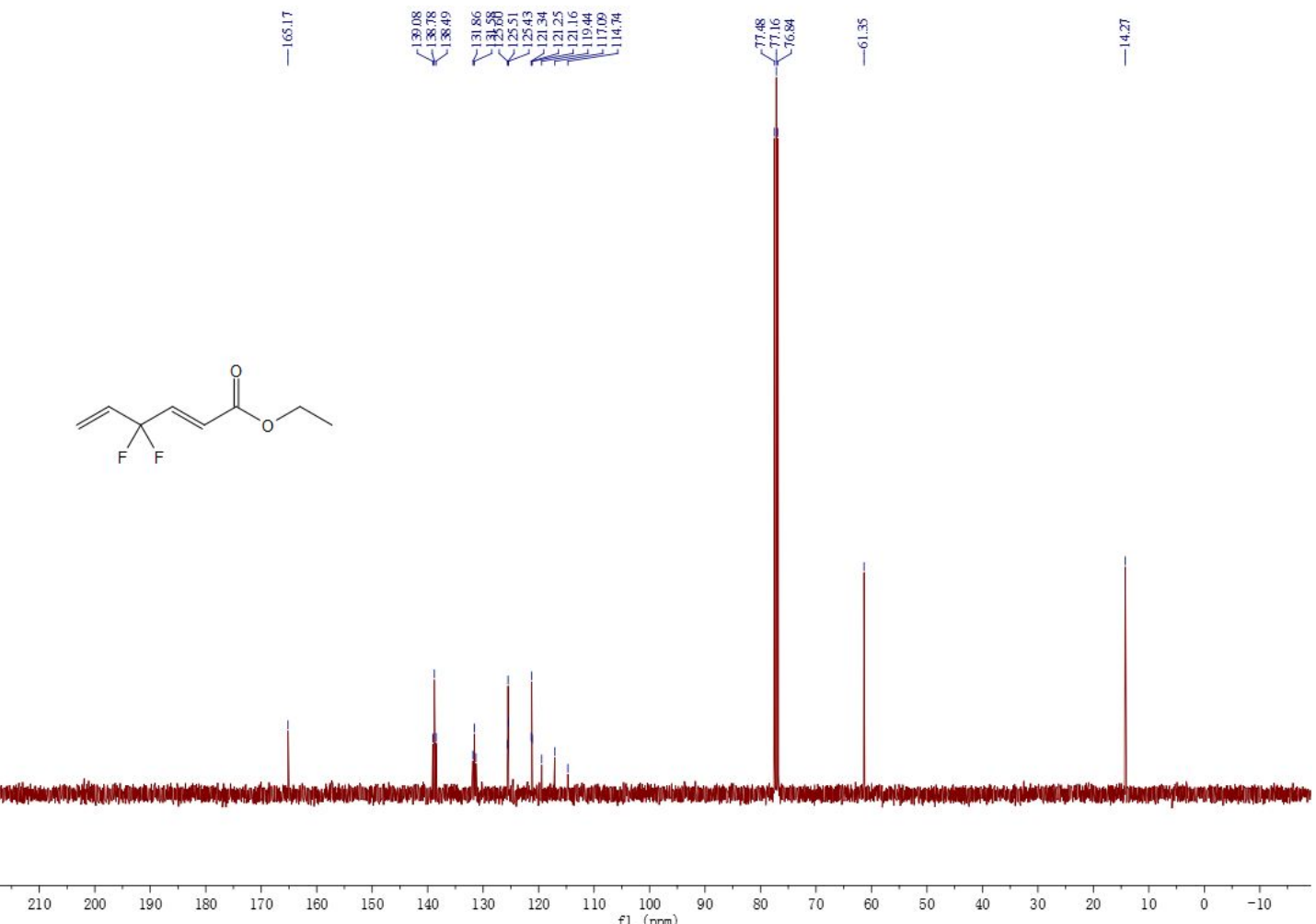
${ }^{1} \mathrm{H}\left(400 \mathrm{MHz}, \mathrm{CDCl}_{3}\right)$ of $\mathbf{6 i}(E / Z=9 / 1)$
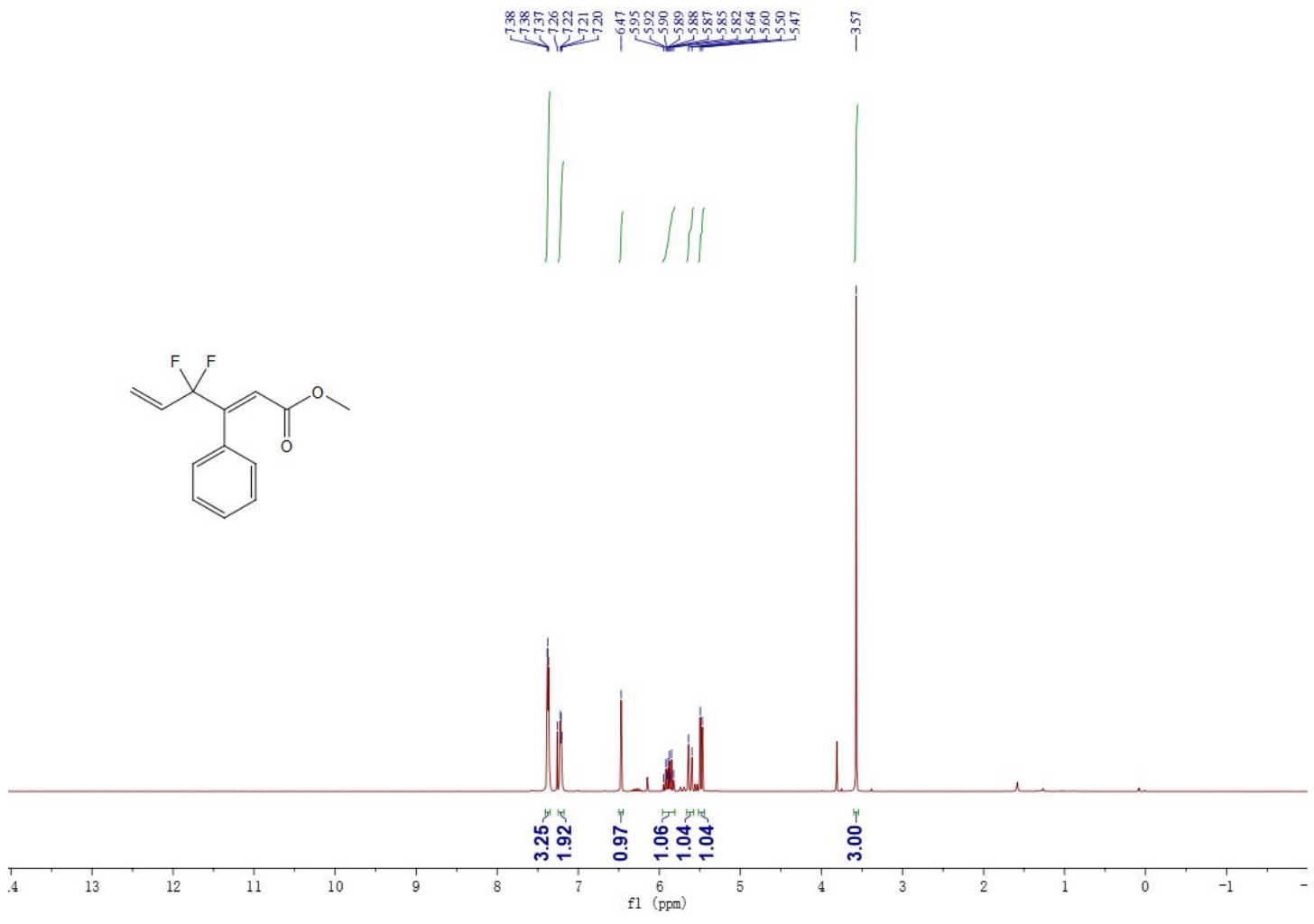

${ }^{19} \mathrm{~F}\left(376 \mathrm{MHz}, \mathrm{CDCl}_{3}\right)$ of $\mathbf{6 i}(E / Z=9 / 1)$
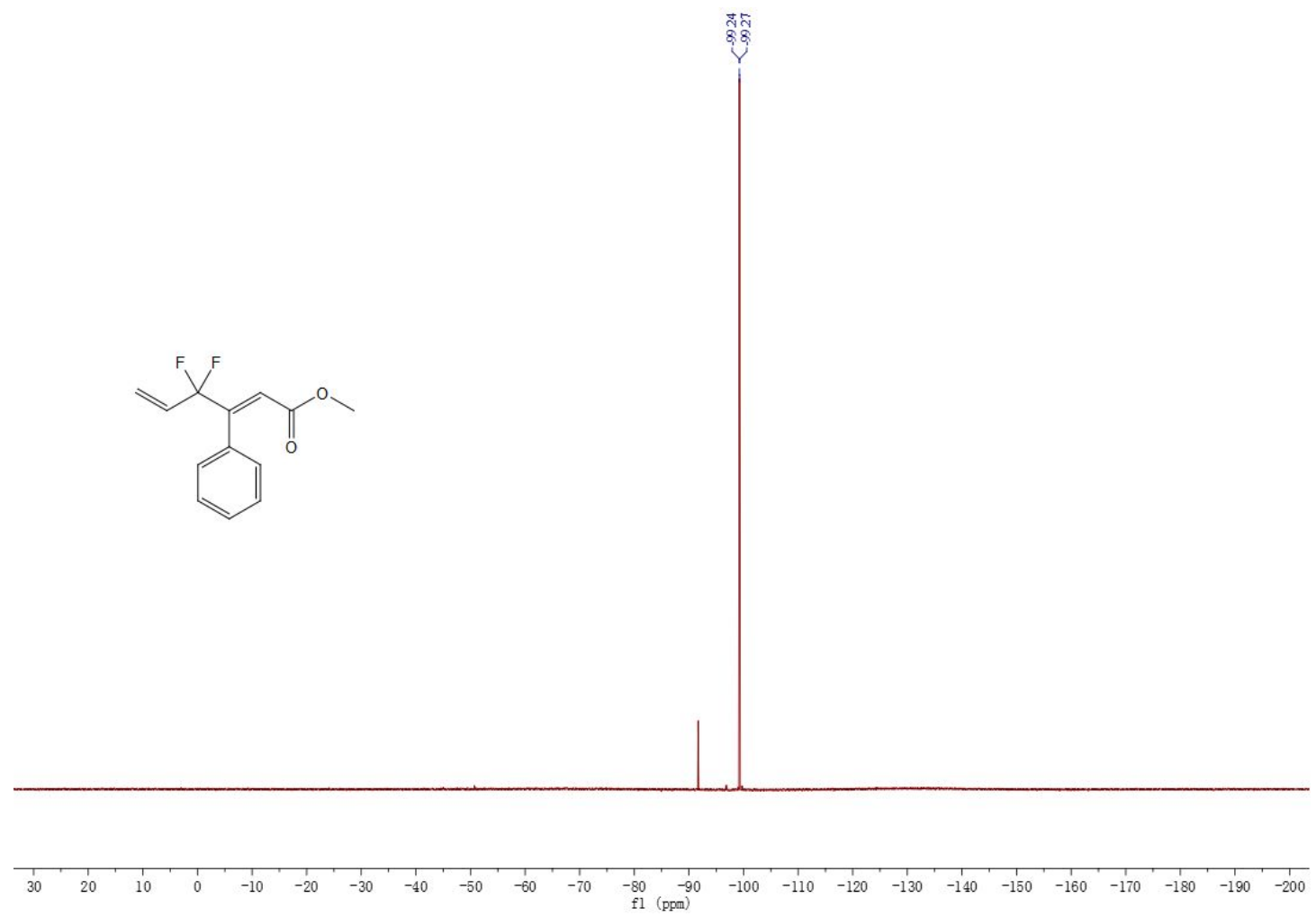

$\mathrm{S} 80$ 
${ }^{13} \mathrm{C}\left\{{ }^{1} \mathrm{H}\right\}\left(101 \mathrm{MHz}, \mathrm{CDCl}_{3}\right)$ of $\mathbf{6 i}(E / Z=9 / 1)$

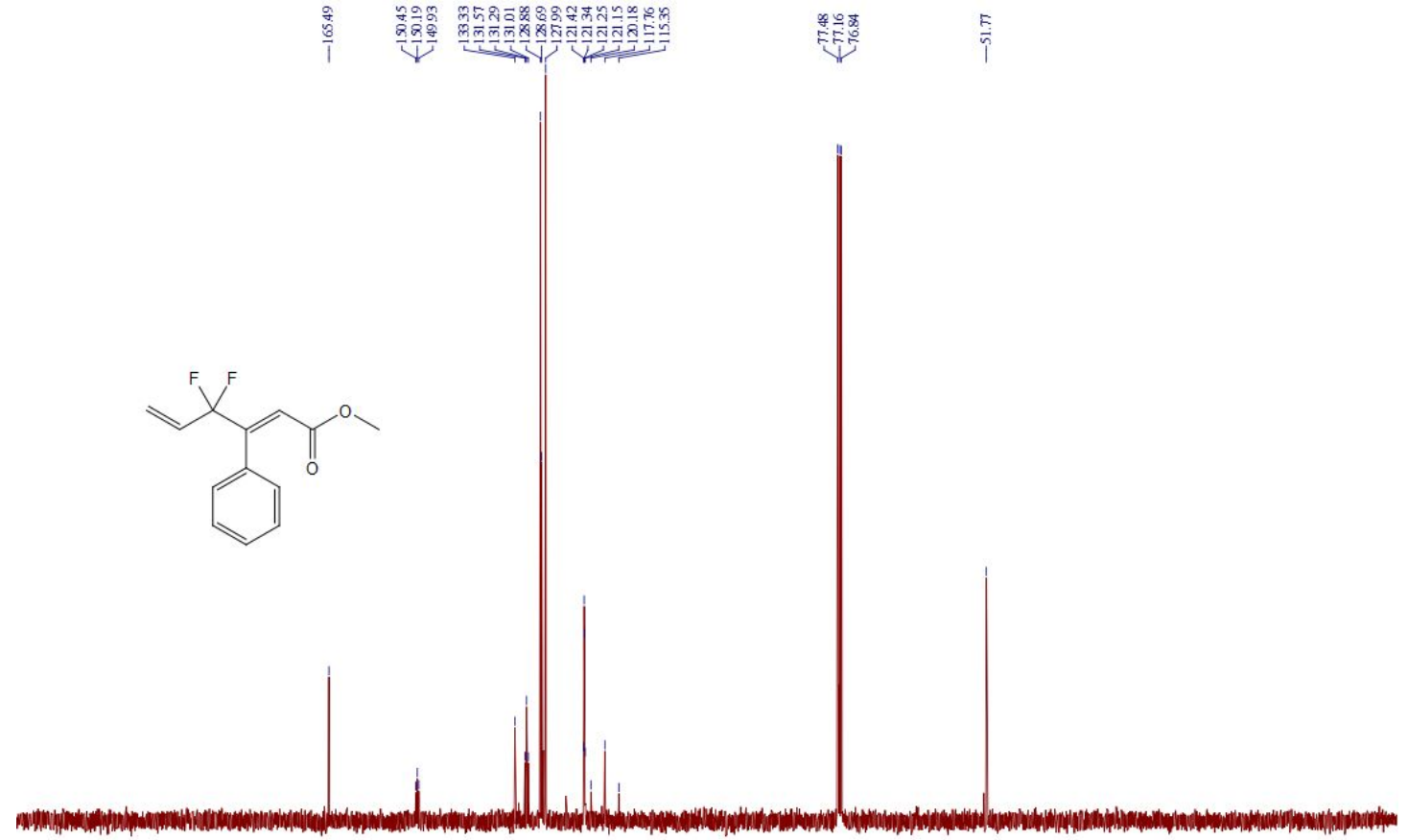

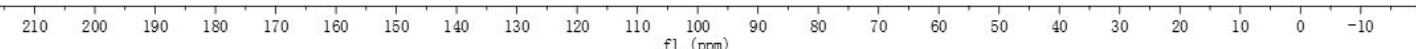

${ }^{1} \mathrm{H}\left(400 \mathrm{MHz}, \mathrm{CDCl}_{3}\right)$ of $\mathbf{8 a}$

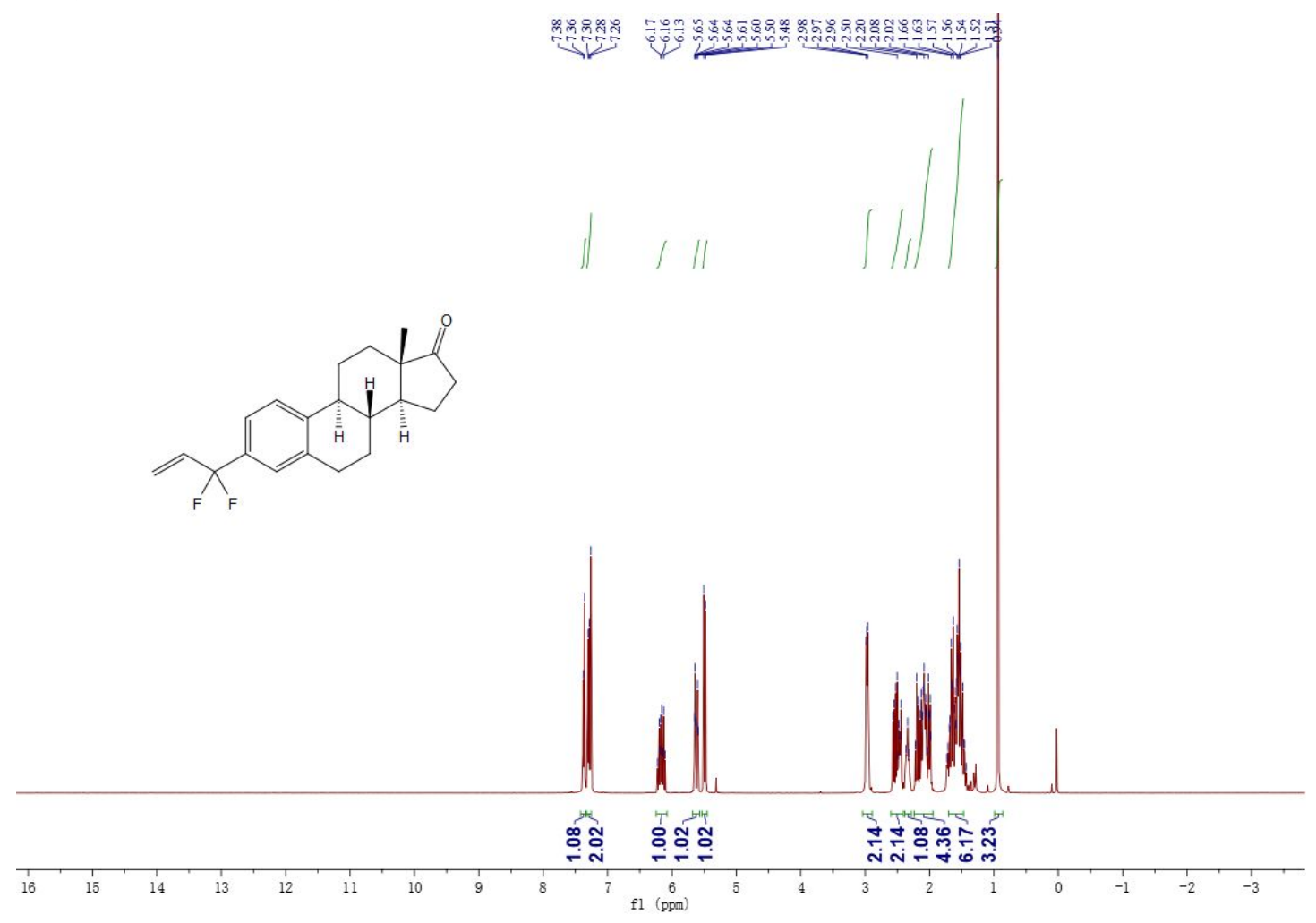


${ }^{19} \mathrm{~F}\left(377 \mathrm{MHz}, \mathrm{CDCl}_{3}\right)$ of $\mathbf{8 a}$
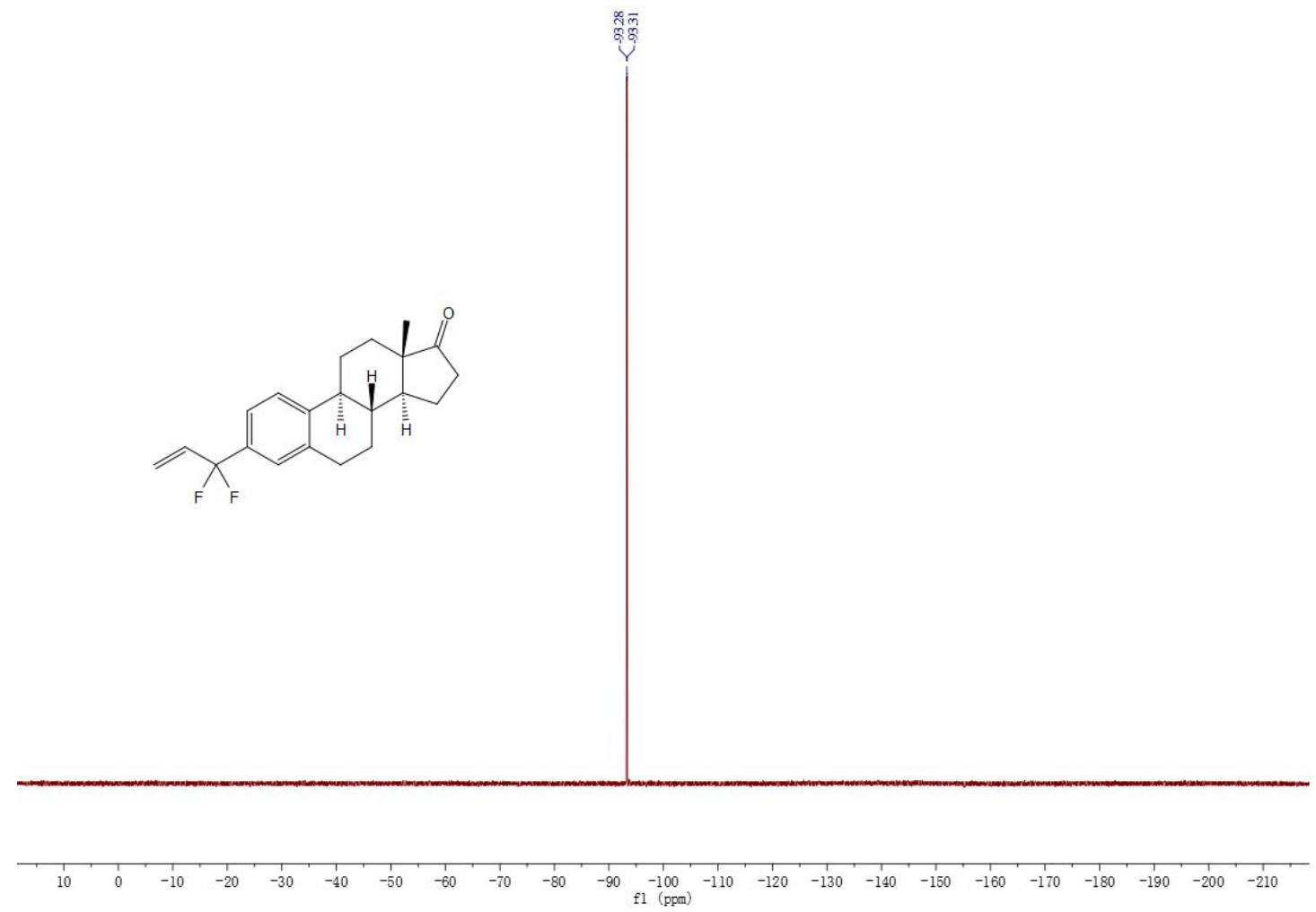

${ }^{13} \mathrm{C}\left\{{ }^{1} \mathrm{H}\right\}\left(101 \mathrm{MHz}, \mathrm{CDCl}_{3}\right)$ of $\mathbf{8 a}$

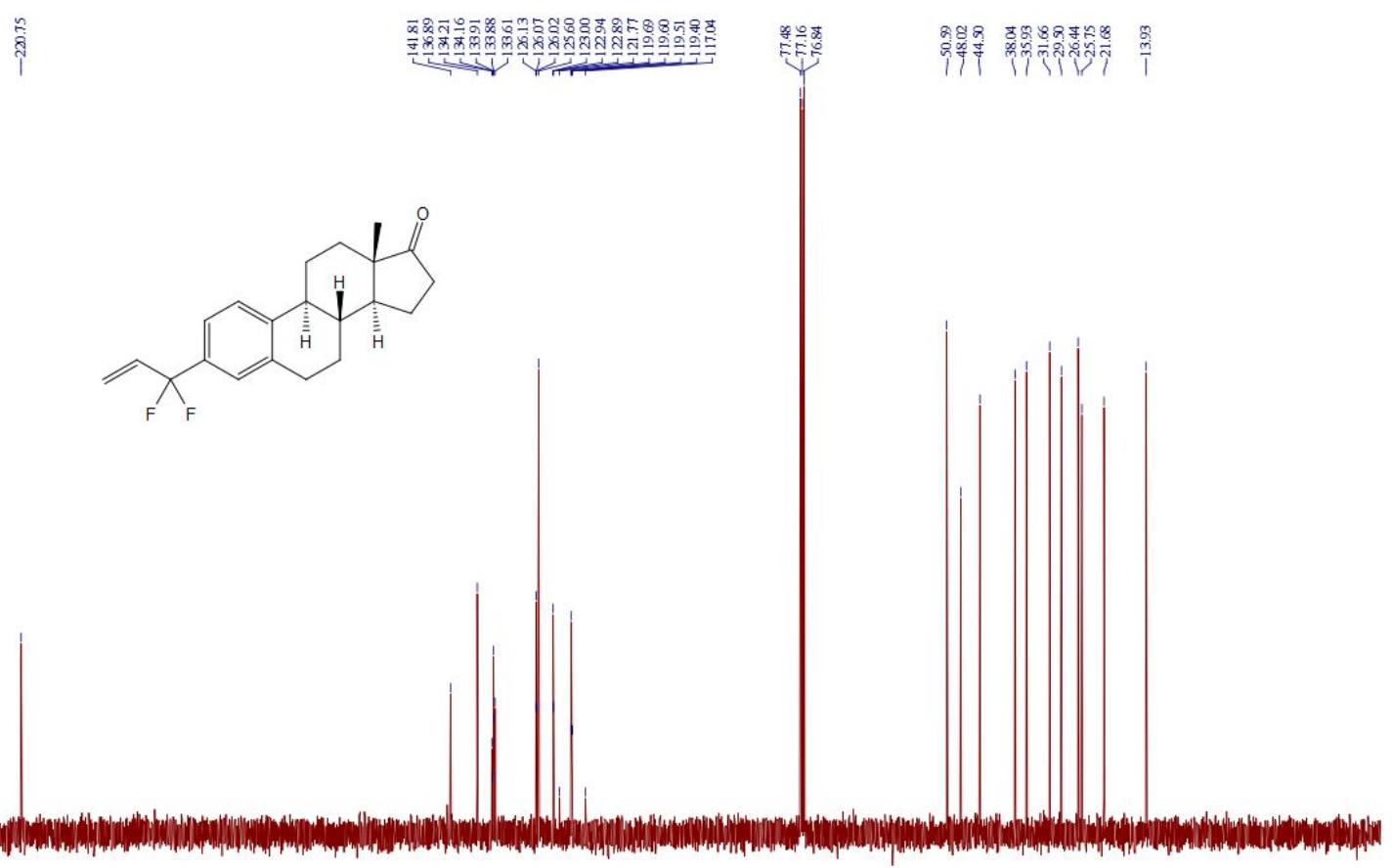

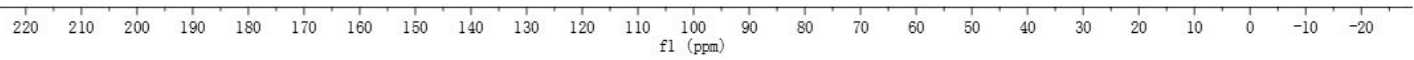


${ }^{1} \mathrm{H}\left(400 \mathrm{MHz}, \mathrm{CDCl}_{3}\right)$ of $\mathbf{8 b}$

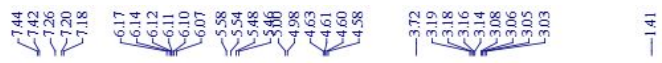
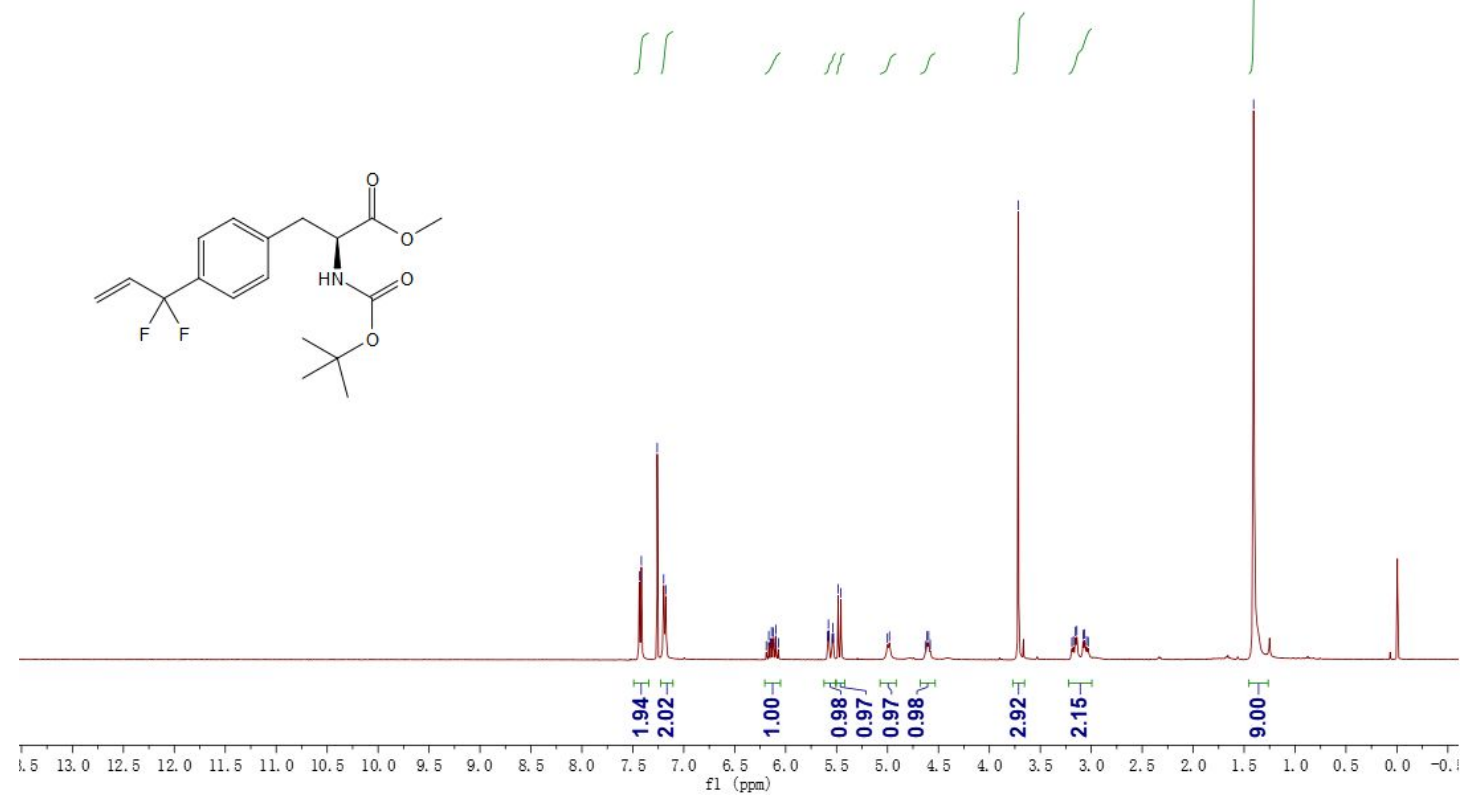

${ }^{19} \mathrm{~F}\left(376 \mathrm{MHz}, \mathrm{CDCl}_{3}\right)$ of $\mathbf{8 b}$

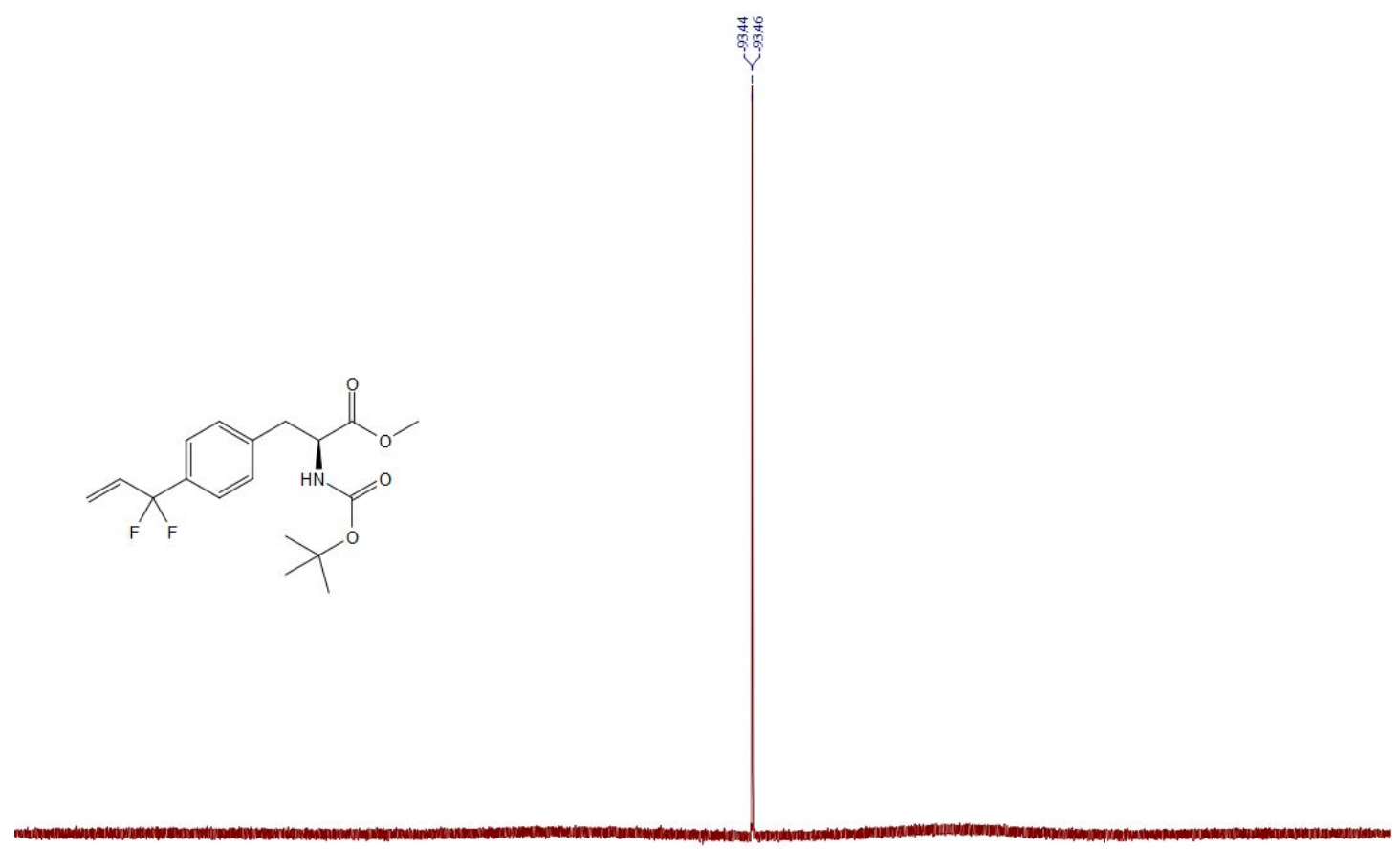

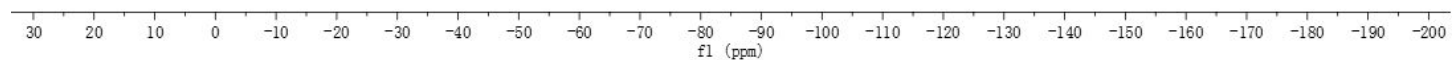


${ }^{13} \mathrm{C}\left\{{ }^{1} \mathrm{H}\right\}\left(176 \mathrm{MHz}, \mathrm{CDCl}_{3}\right)$ of $\mathbf{8 b}$

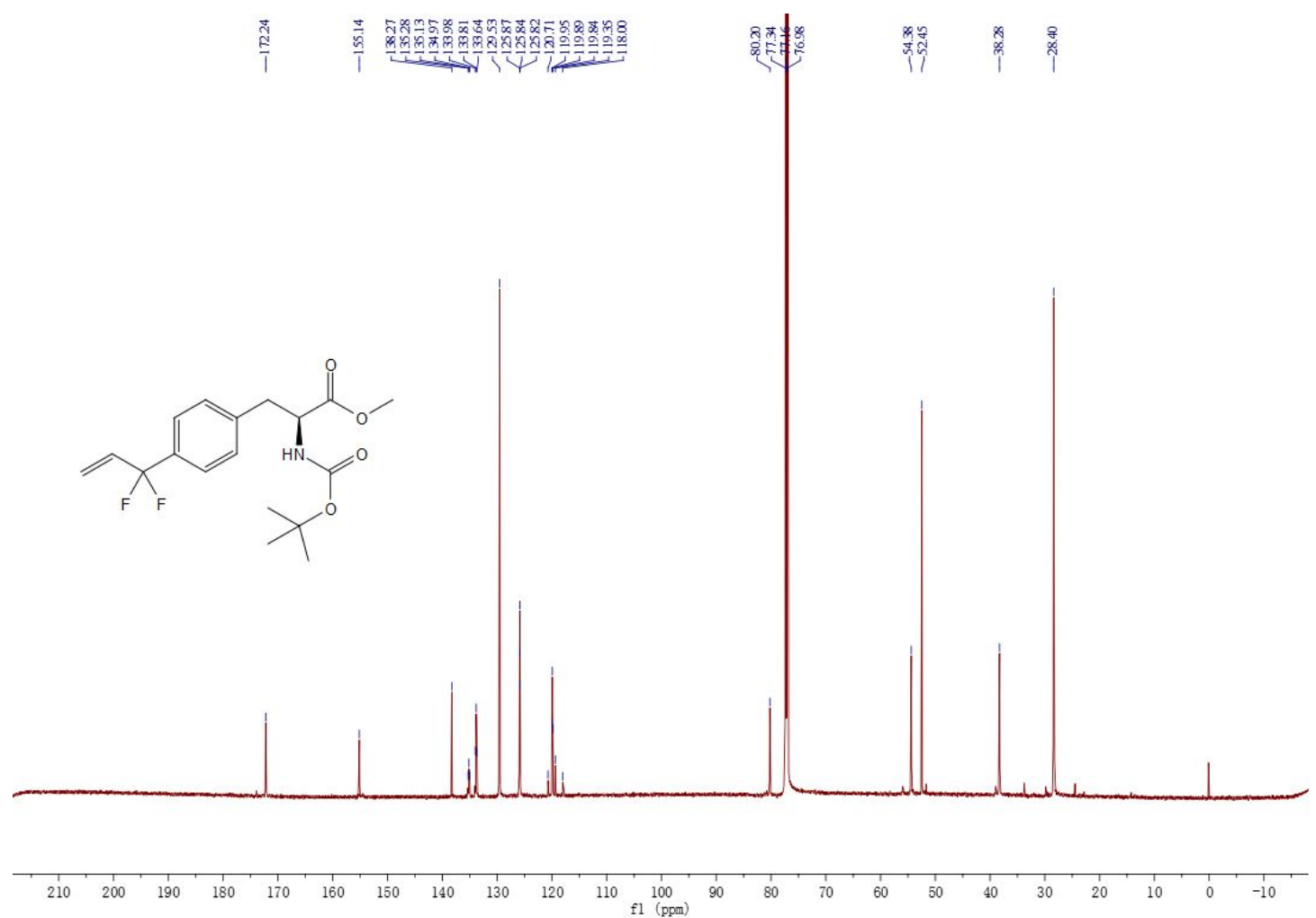

${ }^{1} \mathrm{H}\left(400 \mathrm{MHz}, \mathrm{DMSO}-d_{6}\right)$ of $8 \mathrm{c}$

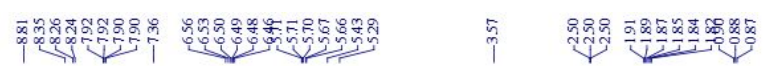
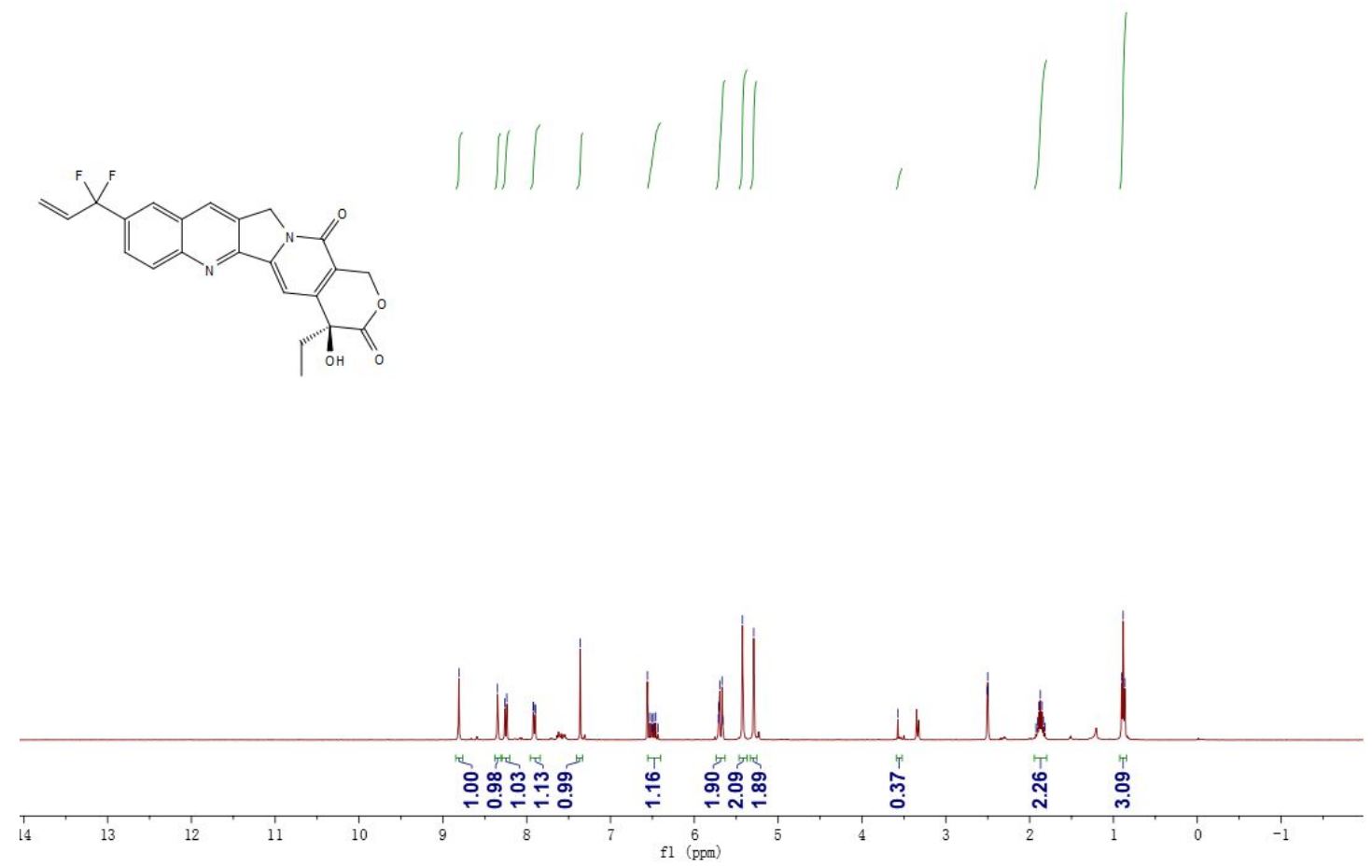
${ }^{19} \mathrm{~F}\left(376 \mathrm{MHz}, \mathrm{DMSO}-d_{6}\right)$ of $\mathbf{8 c}$
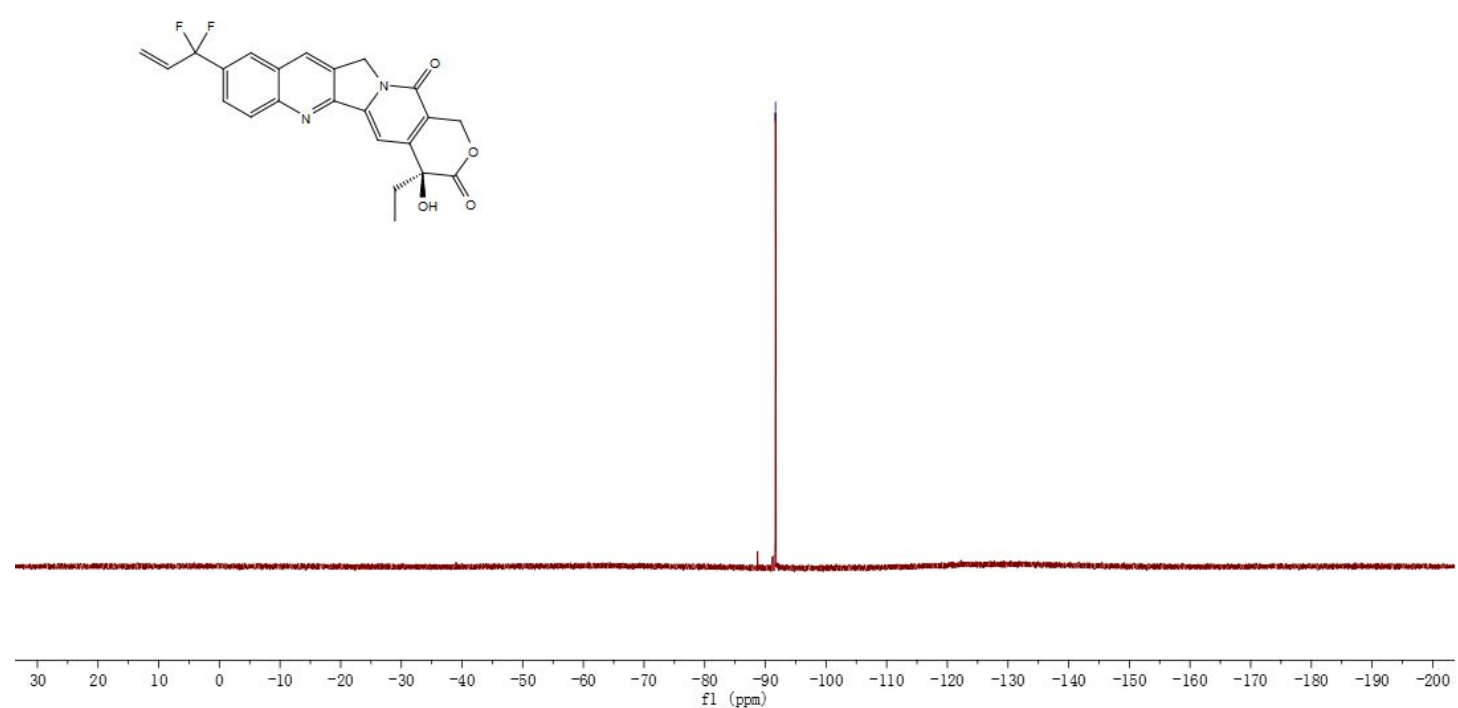

${ }^{13} \mathrm{C}\left\{{ }^{1} \mathrm{H}\right\}\left(176 \mathrm{MHz}, \mathrm{DMSO}-d_{6}\right)$ of $\mathbf{8 c}$

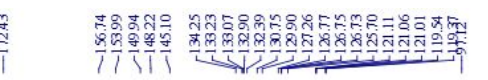

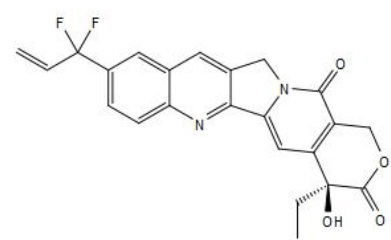

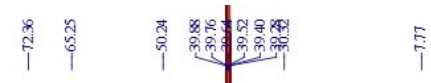
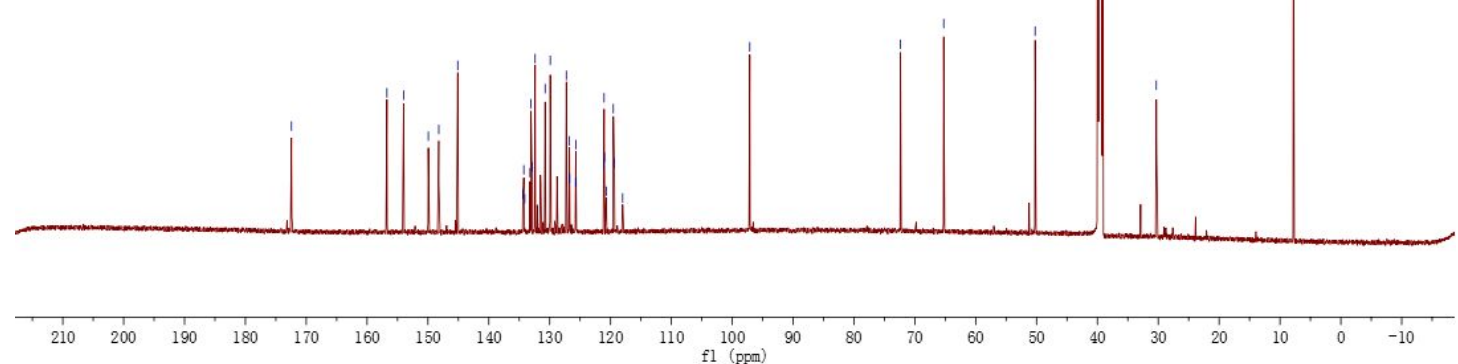
${ }^{1} \mathrm{H}\left(400 \mathrm{MHz}, \mathrm{CDCl}_{3}\right)$ of $\mathbf{8 d}$

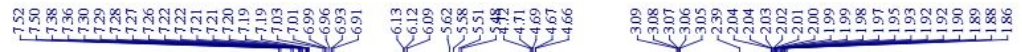
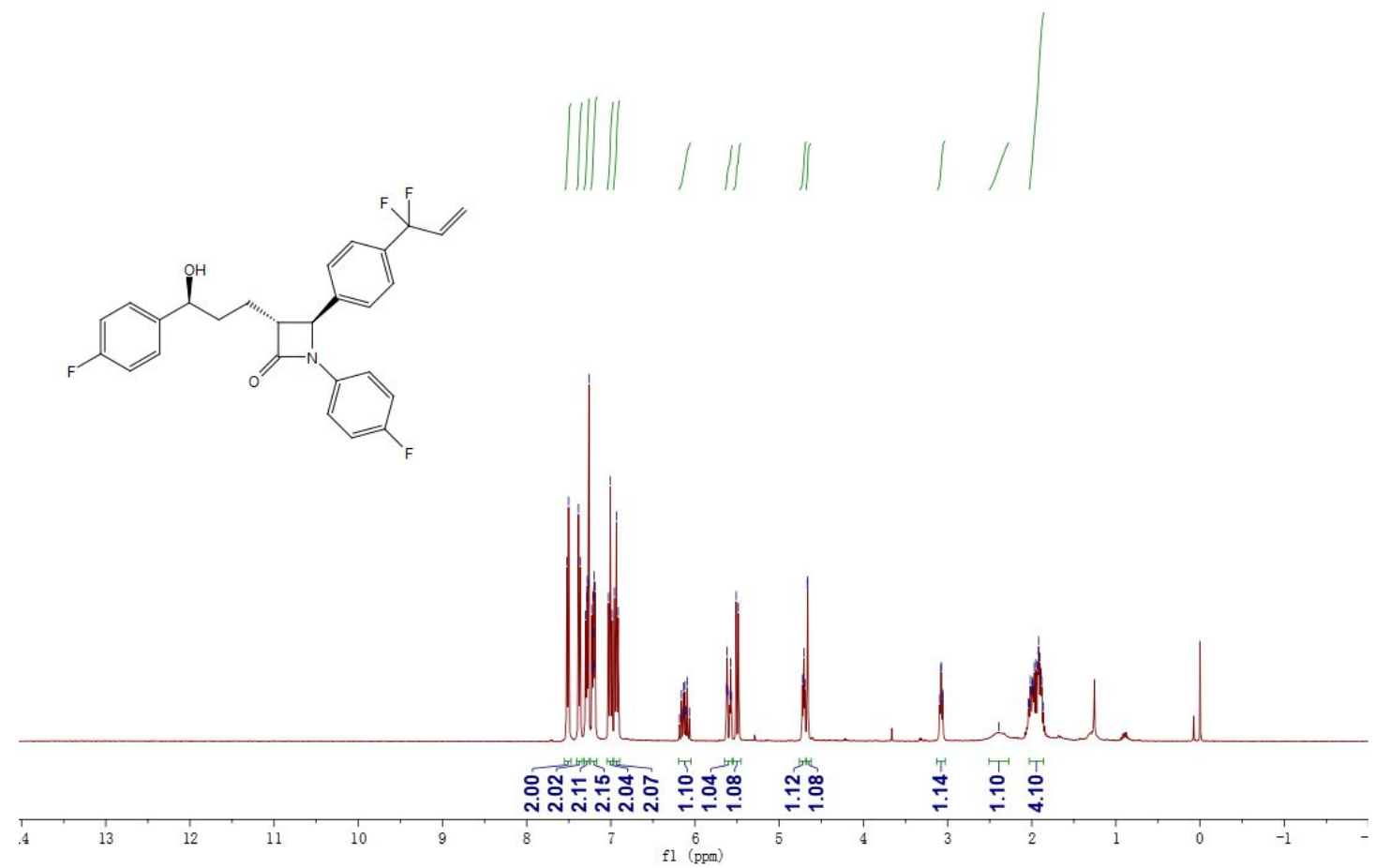

${ }^{19} \mathrm{~F}\left(376 \mathrm{MHz}, \mathrm{CDCl}_{3}\right)$ of $\mathbf{8 d}$
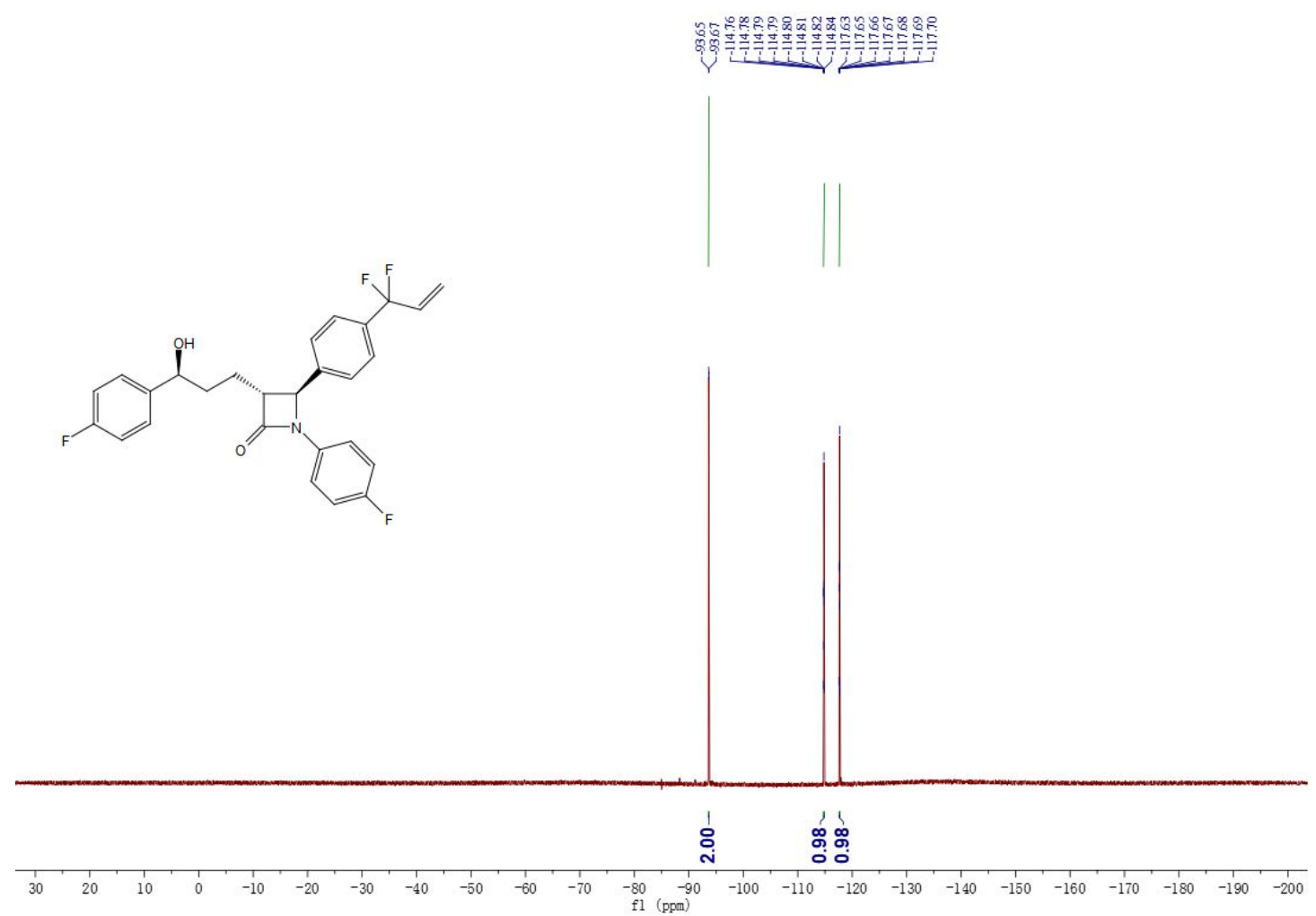


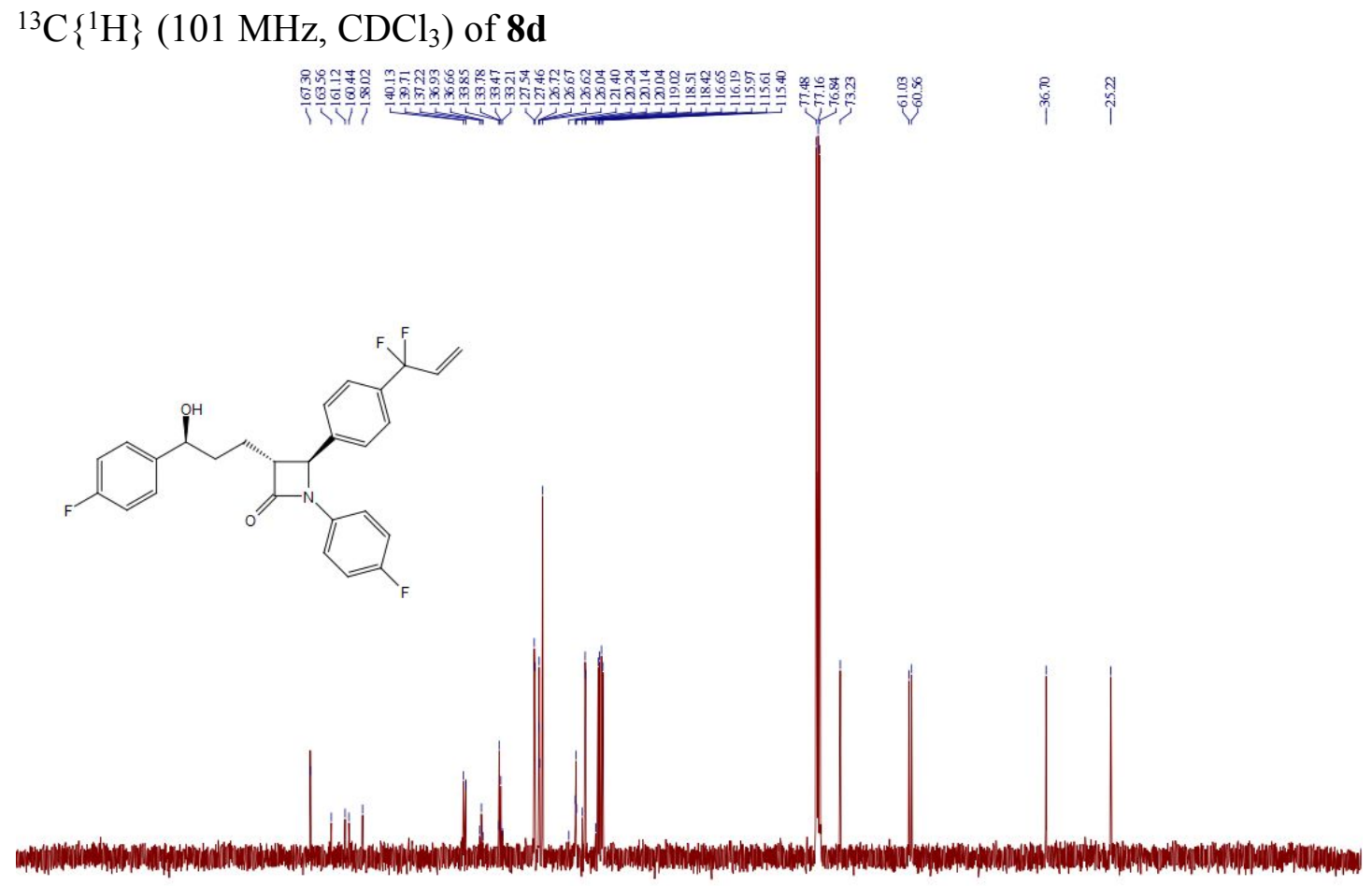

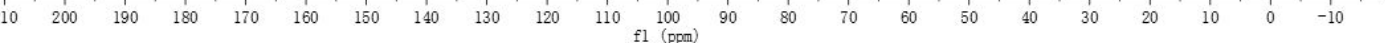

${ }^{1} \mathrm{H}\left(400 \mathrm{MHz}, \mathrm{CDCl}_{3}\right)$ of $\mathbf{8 e}$

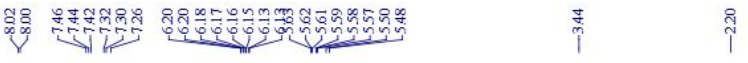

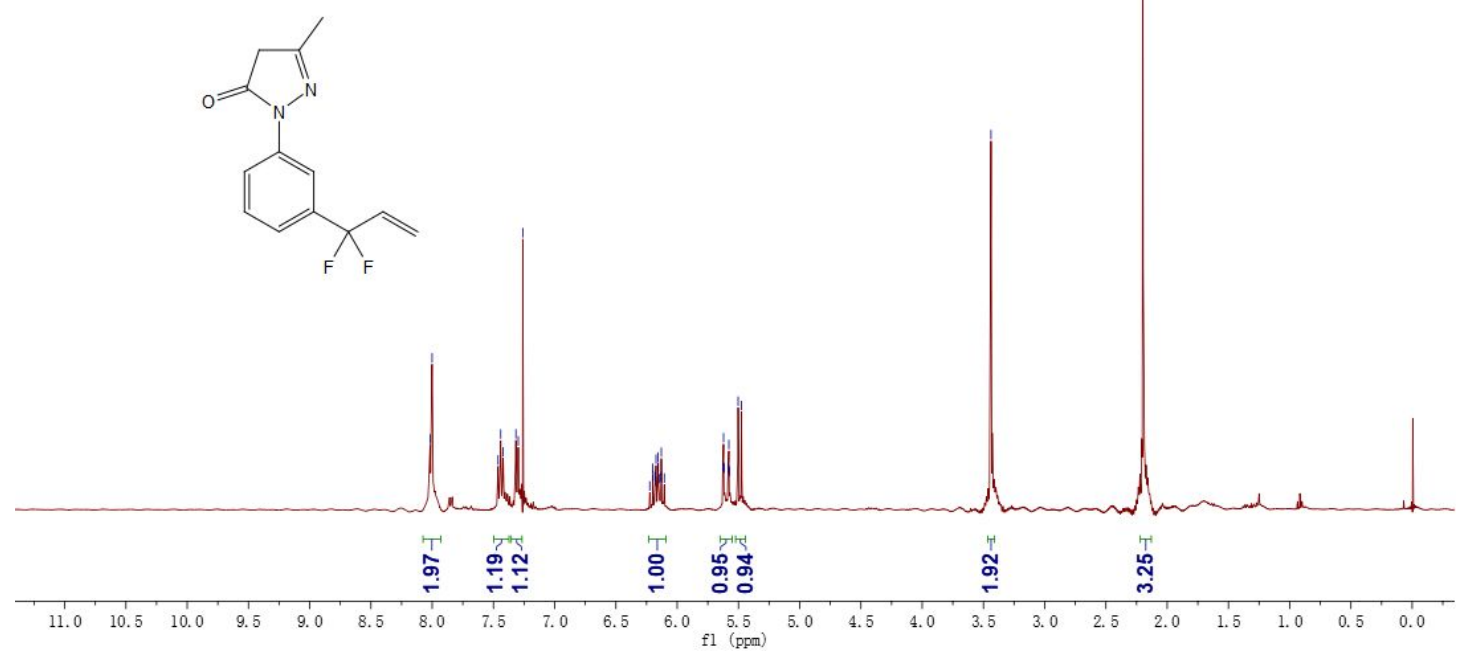


${ }^{19} \mathrm{~F}\left(376 \mathrm{MHz}, \mathrm{CDCl}_{3}\right)$ of $\mathbf{8 e}$
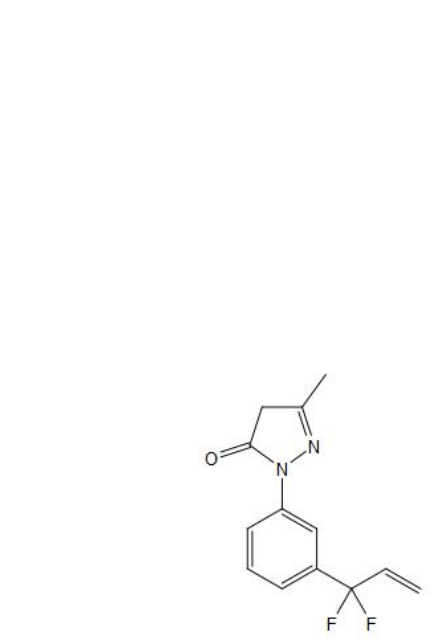

${ }^{13} \mathrm{C}\left\{{ }^{1} \mathrm{H}\right\}\left(101 \mathrm{MHz}, \mathrm{CDCl}_{3}\right)$ of $\mathbf{8 e}$

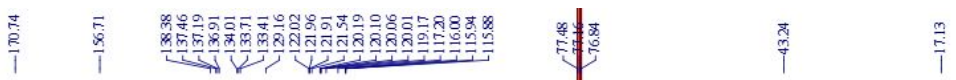

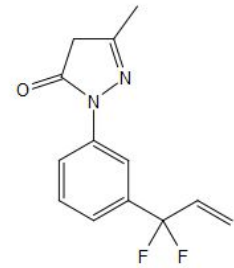

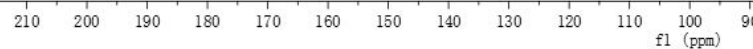


${ }^{1} \mathrm{H}\left(400 \mathrm{MHz}, \mathrm{CDCl}_{3}\right)$ of $\mathbf{8 f}$

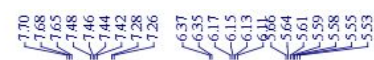

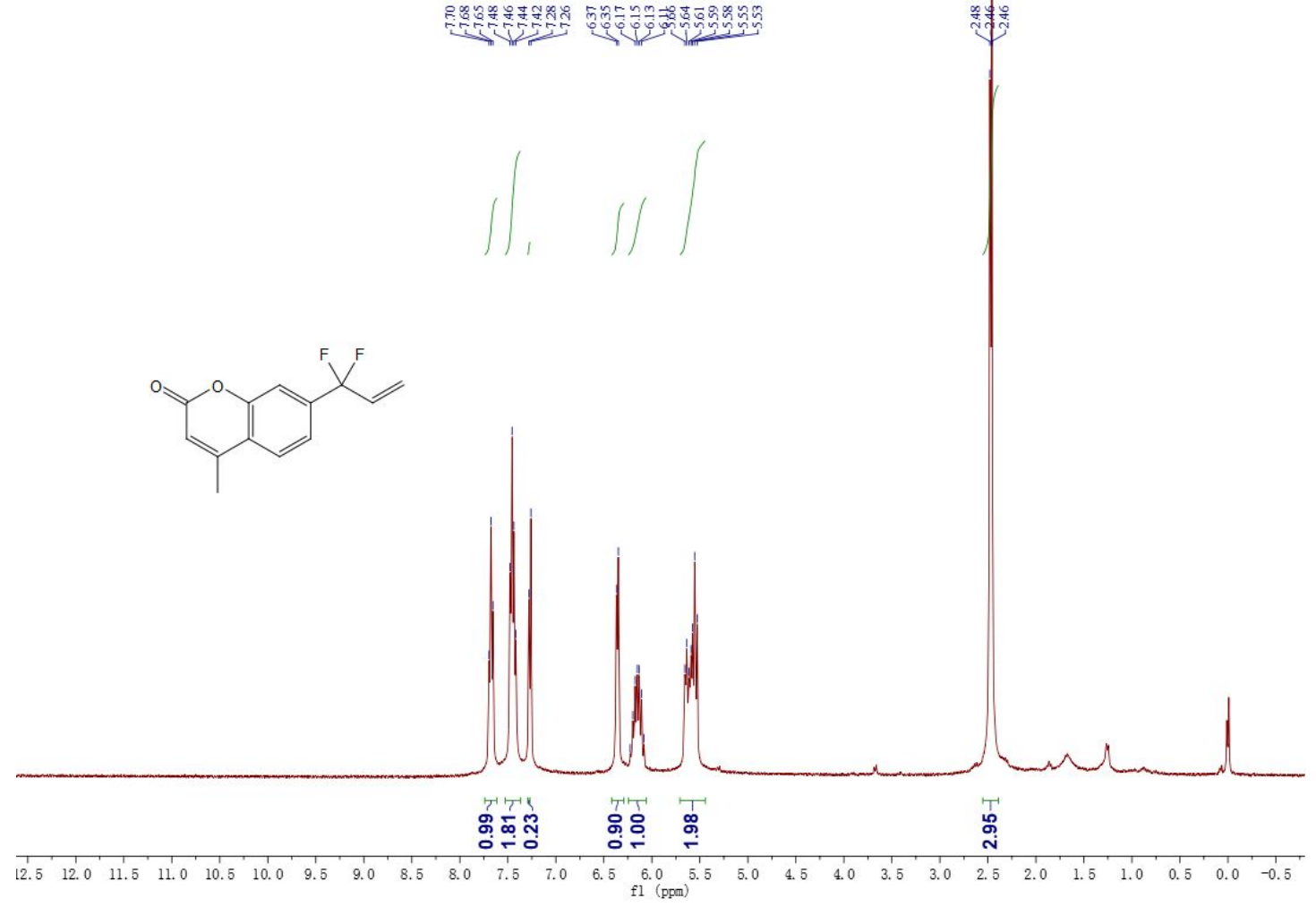

${ }^{19} \mathrm{~F}\left(376 \mathrm{MHz}, \mathrm{CDCl}_{3}\right)$ of $\mathbf{8 f}$

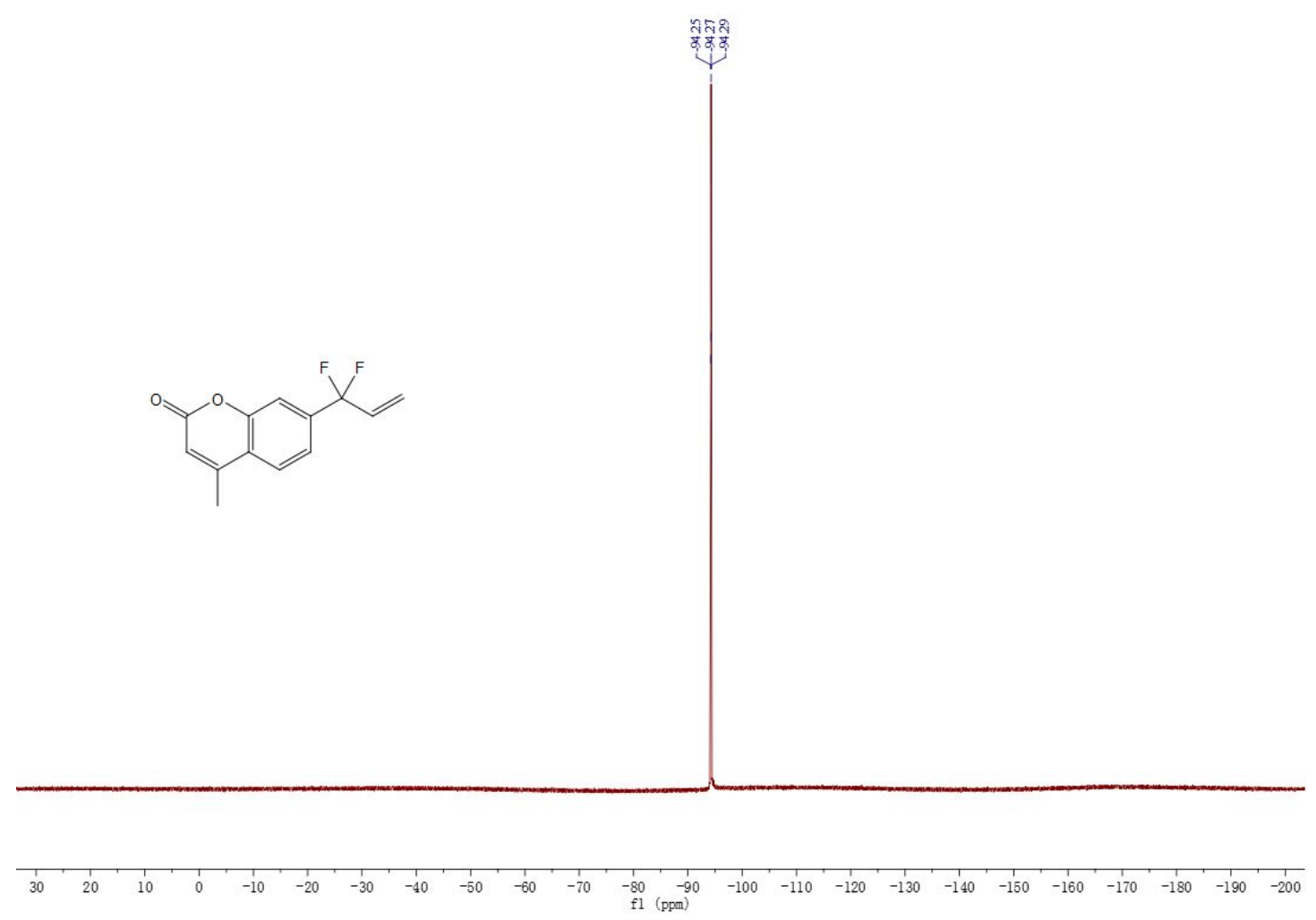


${ }^{13} \mathrm{C}\left\{{ }^{1} \mathrm{H}\right\}\left(176 \mathrm{MHz}, \mathrm{CDCl}_{3}\right)$ of $\mathbf{8 f}$

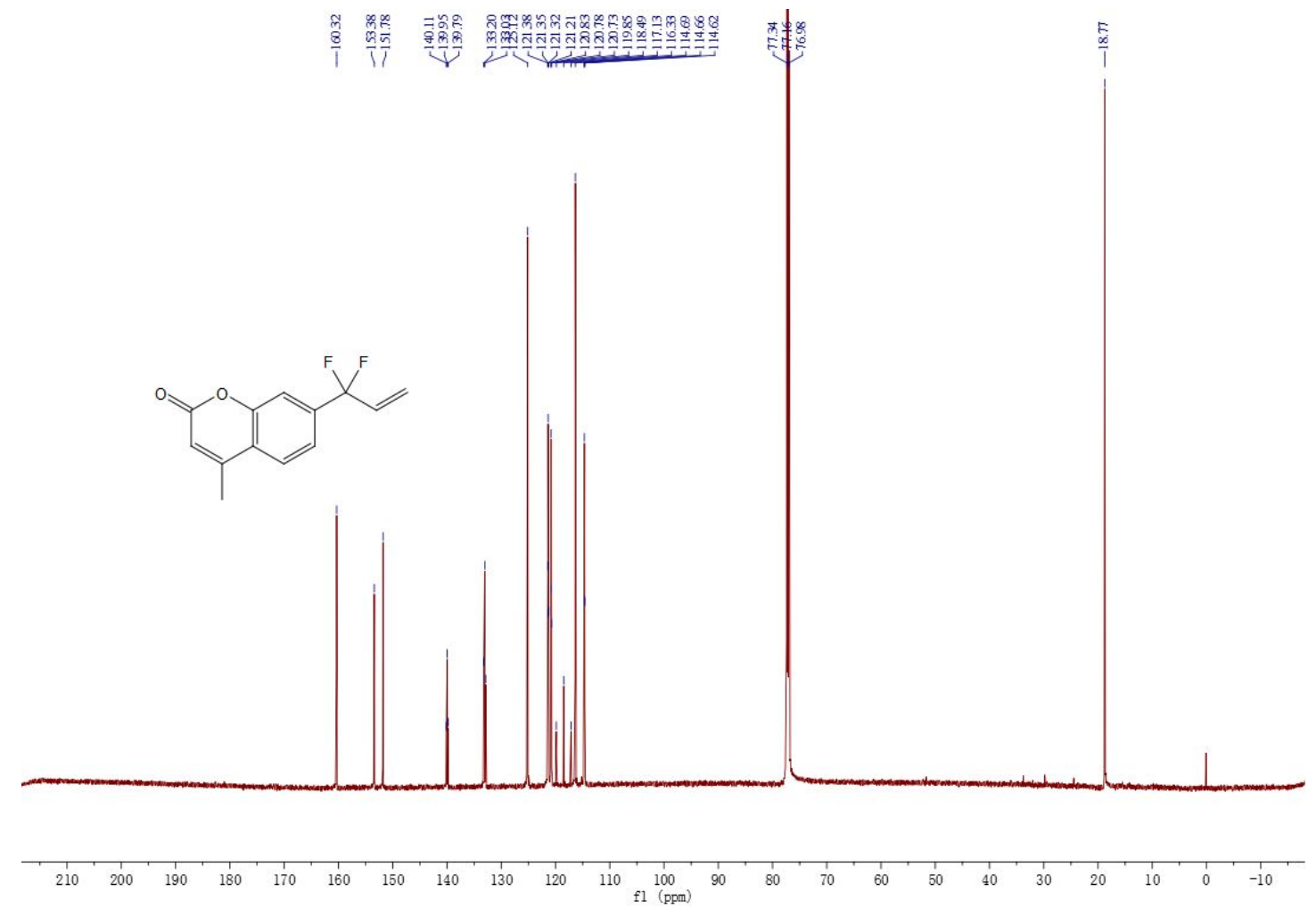

${ }^{1} \mathrm{H}\left(400 \mathrm{MHz}, \mathrm{CDCl}_{3}: \mathrm{MeOH}-\mathrm{d}_{4}=3: 1, \mathrm{~V} / \mathrm{V}\right)$ of 9

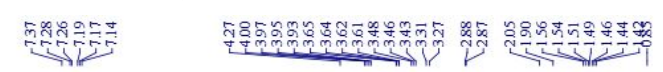

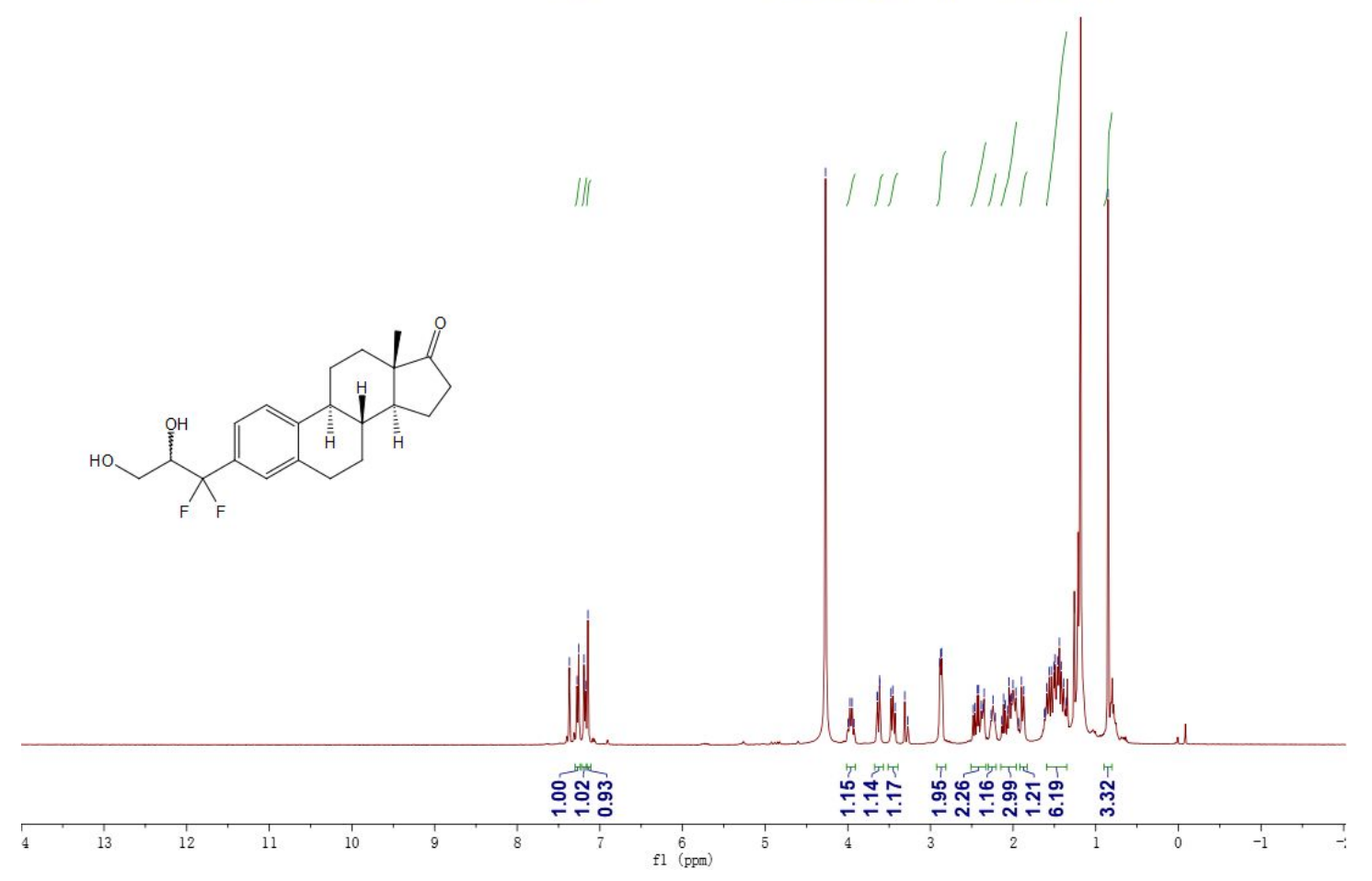


${ }^{19} \mathrm{~F}\left(376 \mathrm{MHz}, \mathrm{CDCl}_{3}: \mathrm{MeOH}-\mathrm{d}_{4}=3: 1, \mathrm{~V} / \mathrm{V}\right)$ of 9

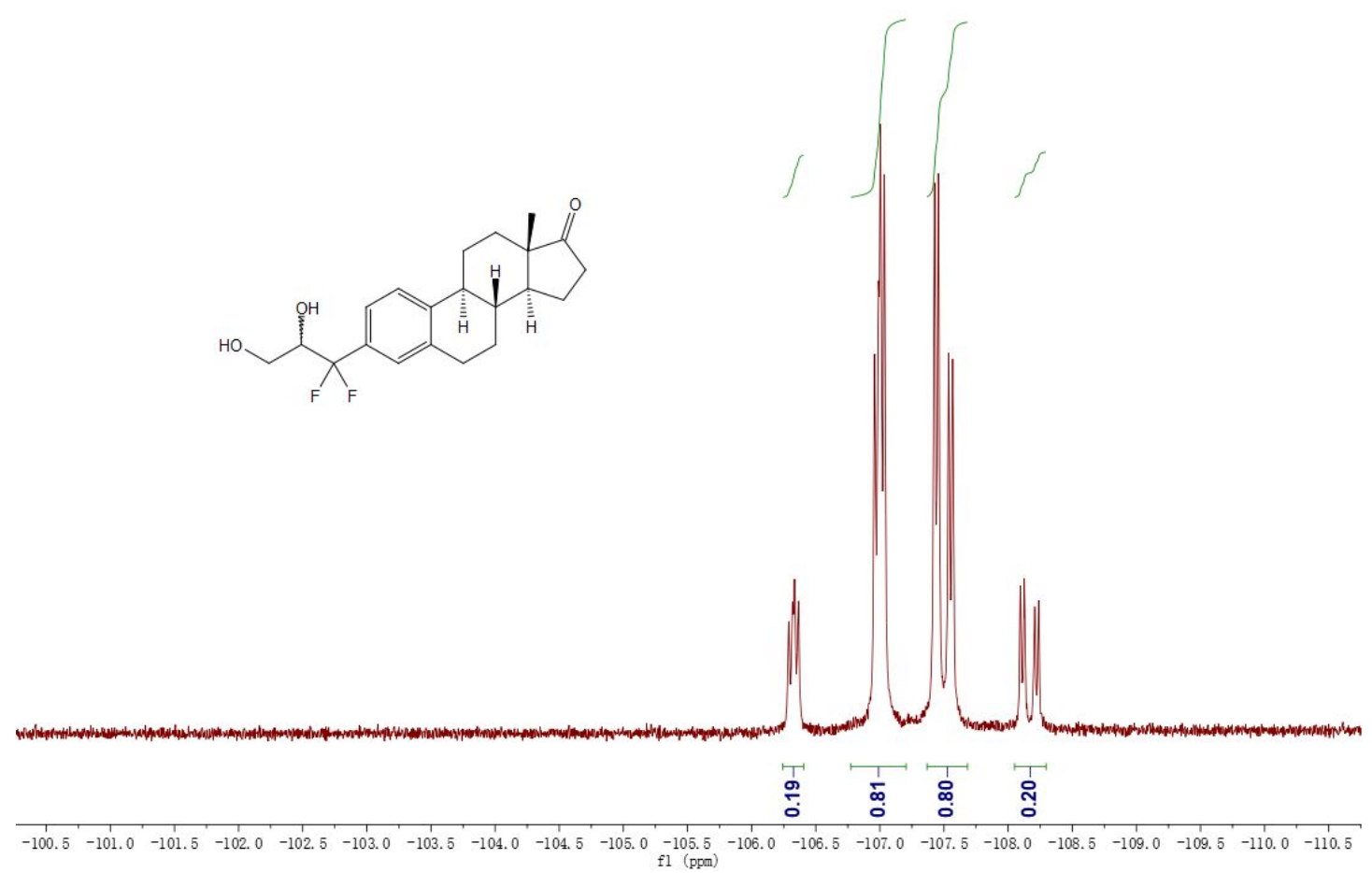

${ }^{13} \mathrm{C}\left\{{ }^{1} \mathrm{H}\right\}\left(101 \mathrm{MHz}, \mathrm{CDCl}_{3}: \mathrm{MeOH}-\mathrm{d}_{4}=3: 1, \mathrm{~V} / \mathrm{V}\right)$ of 9

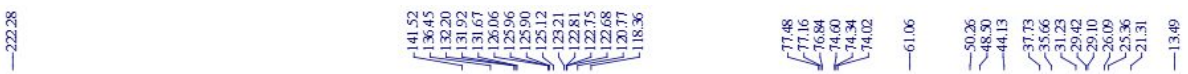
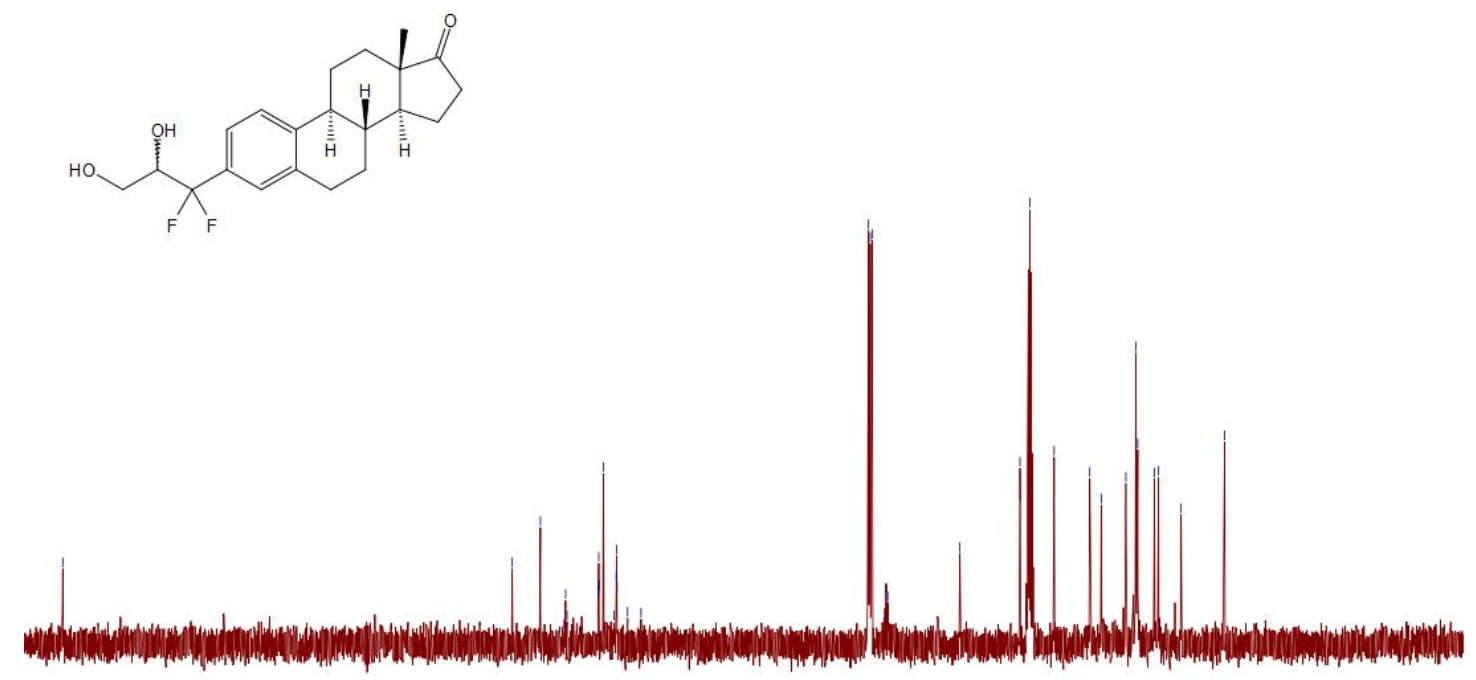

$\begin{array}{llllllllllllllllllllllllllllllllllllll}1 & 220 & 210 & 200 & 190 & 180 & 170 & 160 & 150 & 140 & 130 & 120 & 110 & 100 & 90 & 80 & 70 & 60 & 50 & 40 & 30 & 20 & 10 & 0 & -10 & -20\end{array}$ 
${ }^{1} \mathrm{H}\left(400 \mathrm{MHz}, \mathrm{CDCl}_{3}\right)$ of $\mathbf{1 0}$

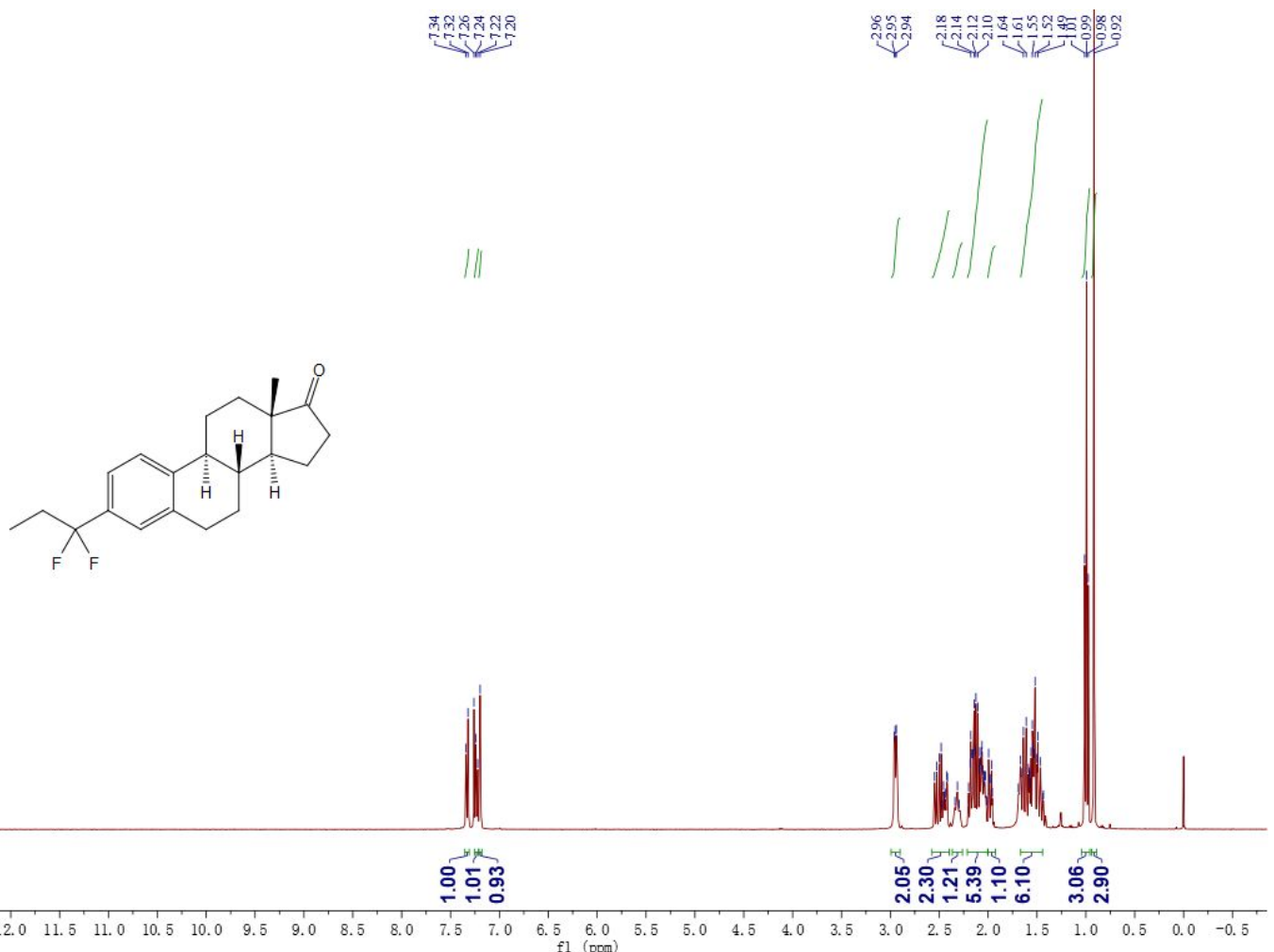

${ }^{19} \mathrm{~F}\left(376 \mathrm{MHz}, \mathrm{CDCl}_{3}\right)$ of $\mathbf{1 0}$
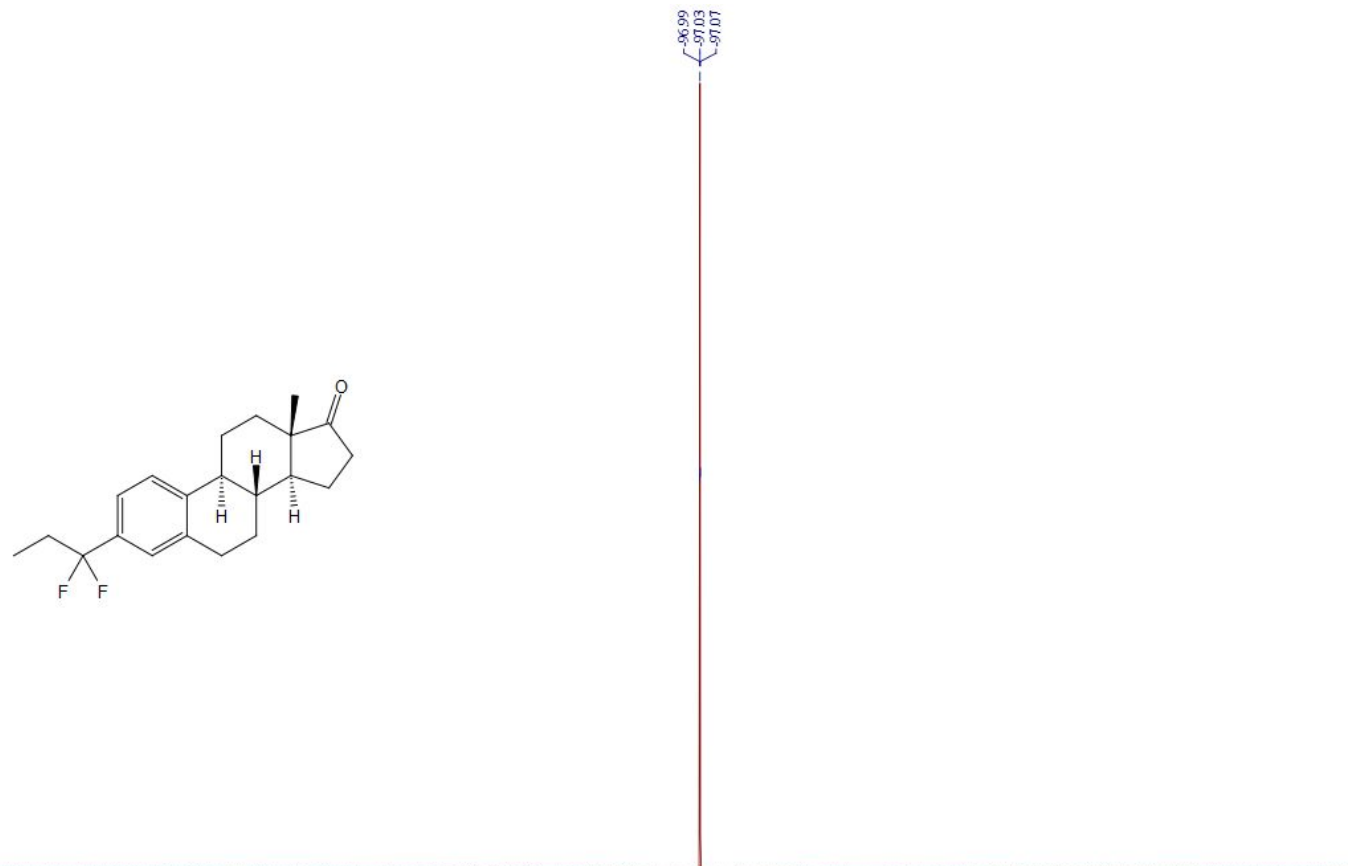

$\begin{array}{lllllllllllllllllllllllllllllllllllllll}1 & 20 & 10 & 0 & -10 & -20 & -30 & -40 & -50 & -60 & -70 & -80 & -90 & -100 & -110 & -120 & -130 & -140 & -150 & -160 & -170 & -180 & -190 & -200\end{array}$ 
${ }^{13} \mathrm{C}\left\{{ }^{1} \mathrm{H}\right\}\left(101 \mathrm{MHz}, \mathrm{CDCl}_{3}\right)$ of $\mathbf{1 0}$

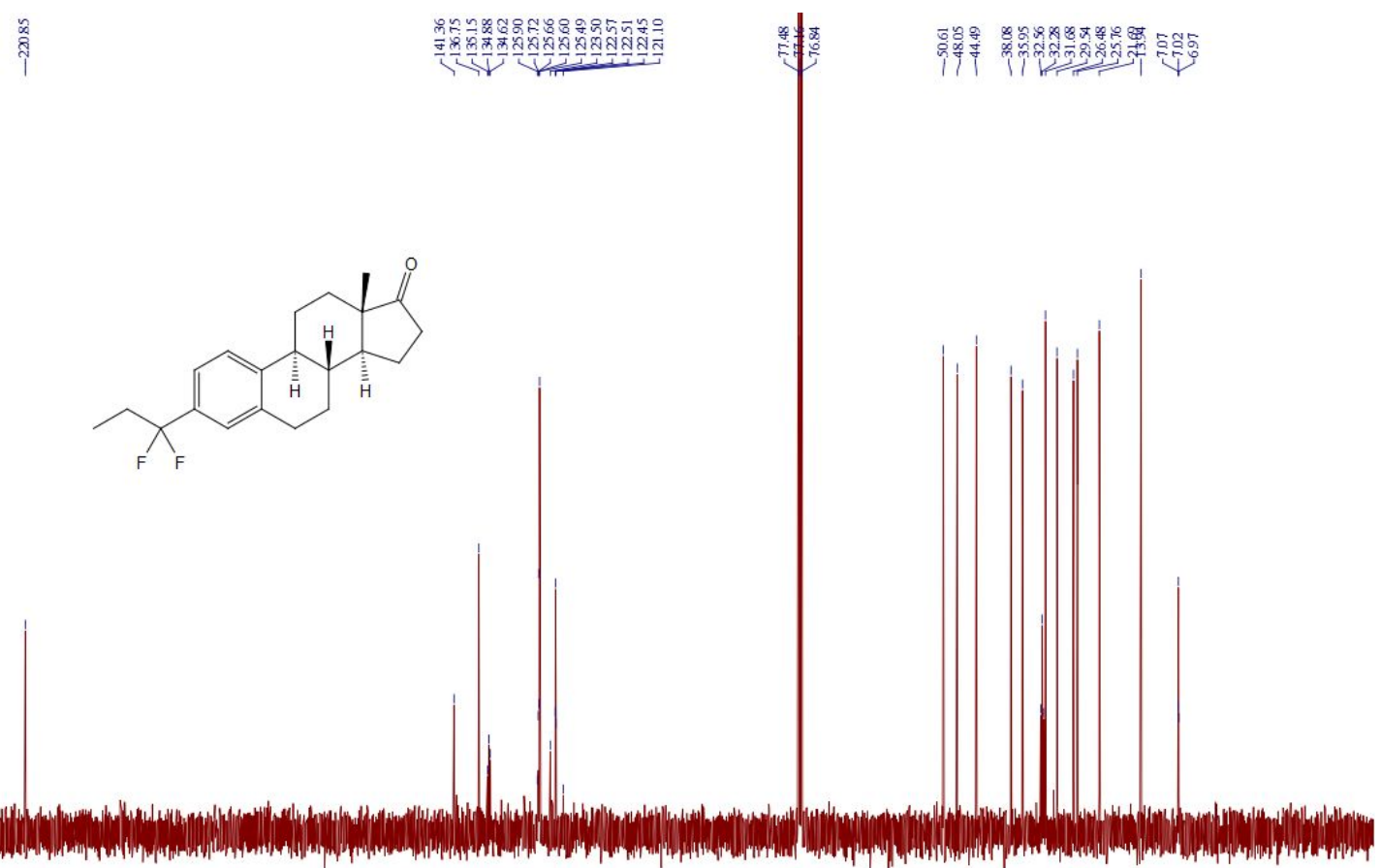

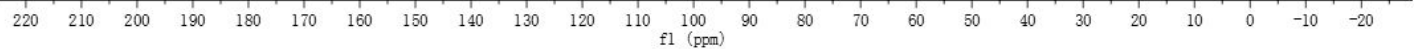

${ }^{1} \mathrm{H}\left(400 \mathrm{MHz}, \mathrm{CDCl}_{3}\right)$ of $\mathbf{1 1}$

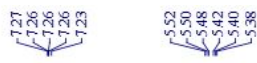

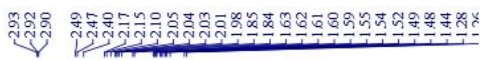
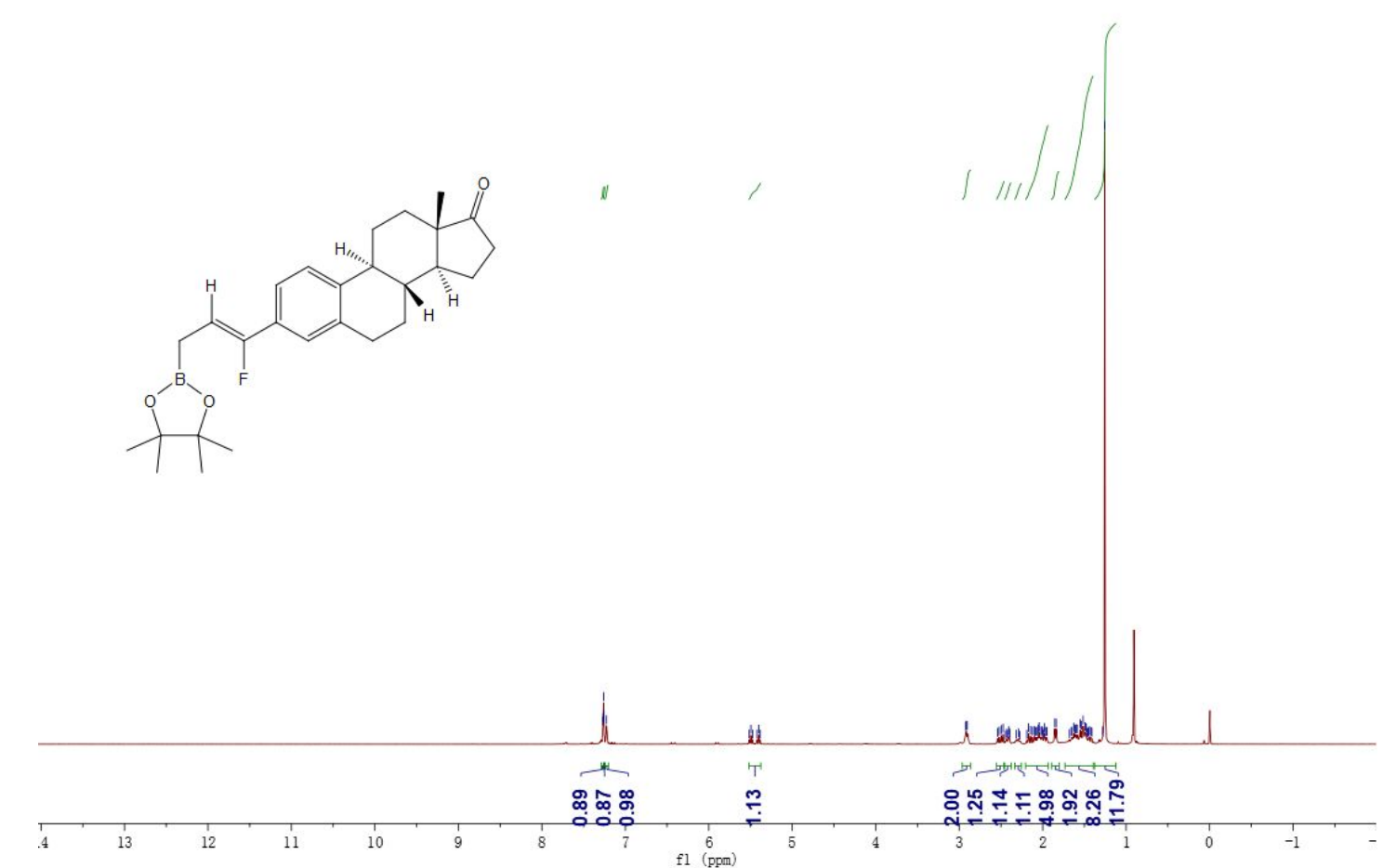
${ }^{19} \mathrm{~F}\left(376 \mathrm{MHz}, \mathrm{CDCl}_{3}\right)$ of $\mathbf{1 1}$
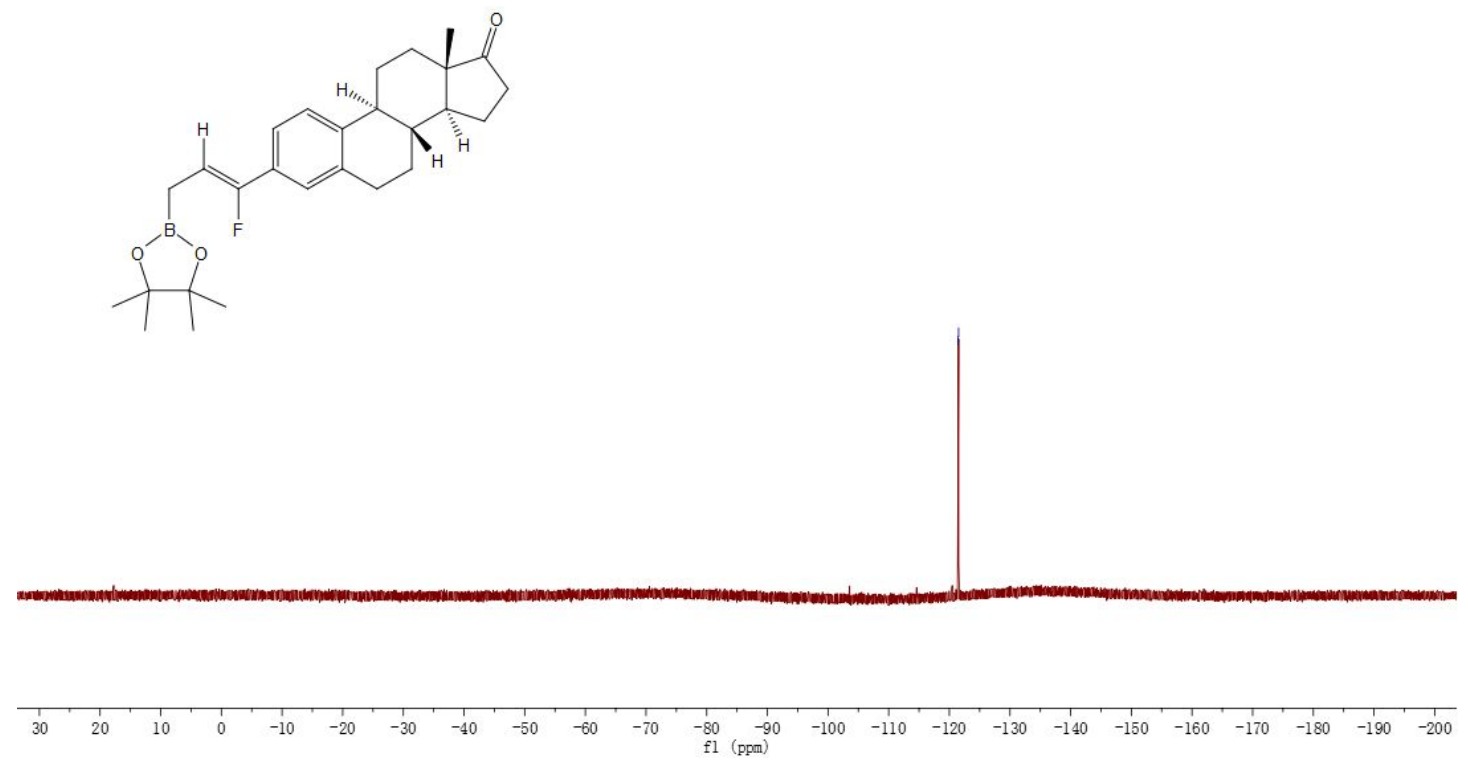

${ }^{13} \mathrm{C}\left\{{ }^{1} \mathrm{H}\right\}\left(176 \mathrm{MHz}, \mathrm{CDCl}_{3}\right)$ of $\mathbf{1 1}$

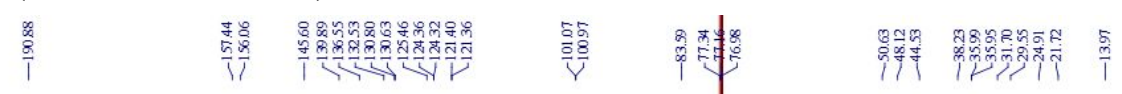

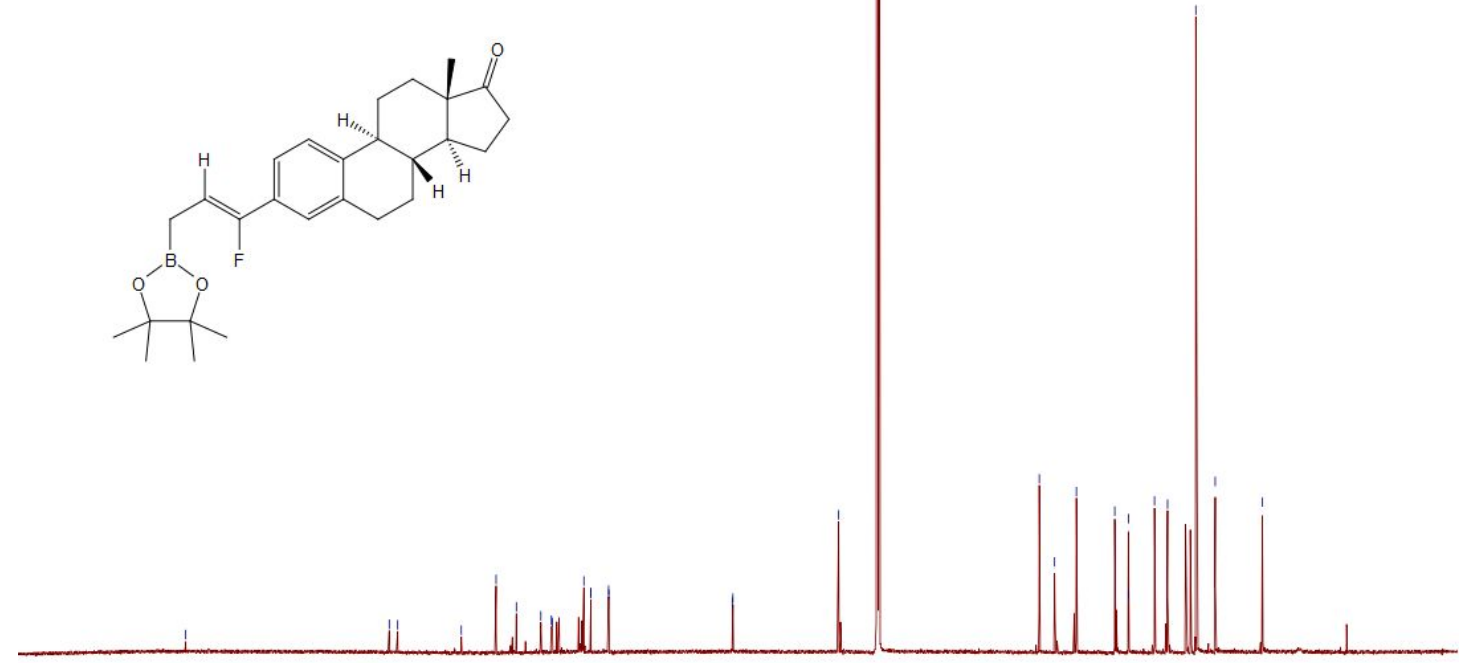

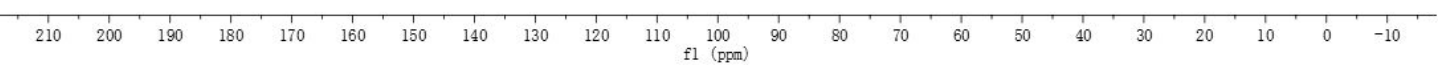

